University of Louisville

ThinkIR: The University of Louisville's Institutional Repository

Electronic Theses and Dissertations

1939

\title{
The social administration of camps in the Louisville area.
}

Dorothy Bryan Haddock 1916-2008

University of Louisville

Follow this and additional works at: https://ir.library.louisville.edu/etd

Part of the Public Administration Commons

\section{Recommended Citation}

Haddock, Dorothy Bryan 1916-2008, "The social administration of camps in the Louisville area." (1939). Electronic Theses and Dissertations. Paper 1800.

https://doi.org/10.18297/etd/1800

This Master's Thesis is brought to you for free and open access by ThinkIR: The University of Louisville's Institutional Repository. It has been accepted for inclusion in Electronic Theses and Dissertations by an authorized administrator of ThinkIR: The University of Louisville's Institutional Repository. This title appears here courtesy of the author, who has retained all other copyrights. For more information, please contact thinkir@louisville.edu. 
OHIVERSIT of LO0I8VILI

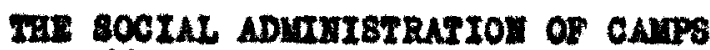

11

II THE LOJI8TILLE ARA

\author{
A Diseortation \\ subuatted to the raoulty

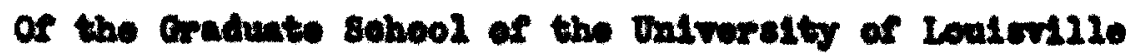 \\ In Partind Fulfiluont of the \\ Regul rwante for the Dogee

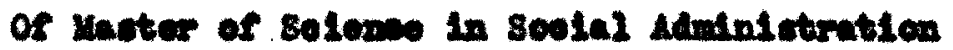

Divielon as soelal sdminiotration

B.

Dow why Brym Haddeok

2030 
Lume of Bxubsur, Derothy Brym Heddeok

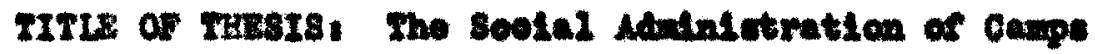

In the touterd20 Are

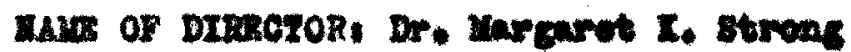

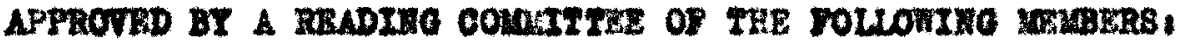

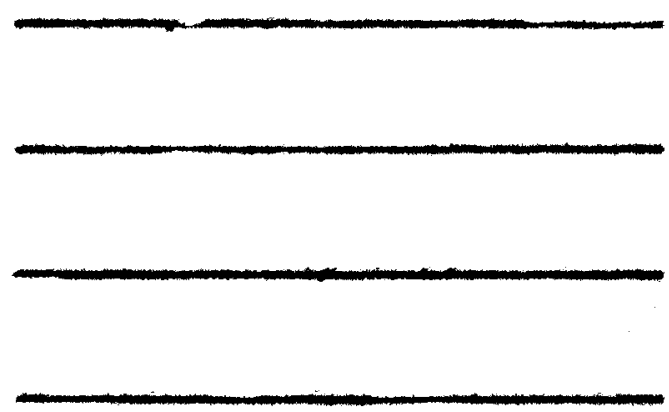

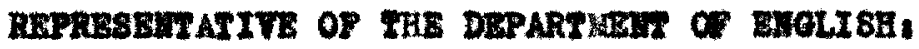

DATE: Jum 6, 2080 


\title{
ABSREVIATIOMS
}

\author{
Y.H.C.A. Young Wown' Chriatien Aseoolation \\ Y.M.C.A. Toung Hon's Chrietian Aseoolation \\ F.E.R.A. Fedoral bergenoy Rellor Adulntettution \\ T.H.H.A. Young Von's Hobrom Ascoslation \\ I.I.A. Iational Youth Admini otratios \\ W. P. A. Worke Progrose Adninlotration
}




\section{ACxNOWLEDEEM}

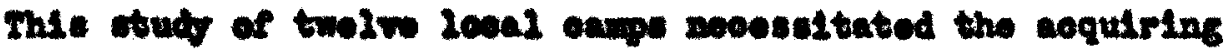

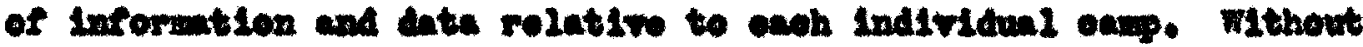

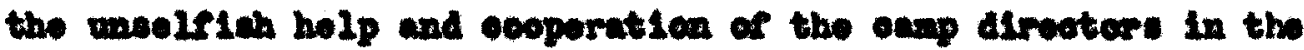
arve studied, woh mterial oonld not hare boon obtalnod. To onoh

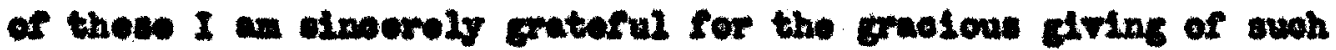

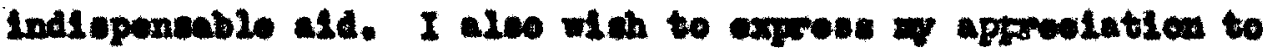

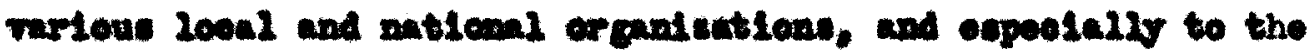
Loulurile Combll of seotel Agenstes for thetr gonorous oontributlon of papinlote and books ocutalaing valuble materiel portinont to this condy.

I win partioularly te celmenledpe ar Indobtednose to

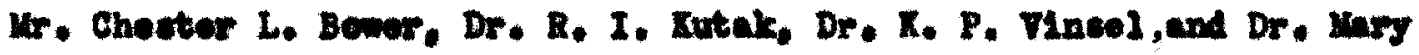

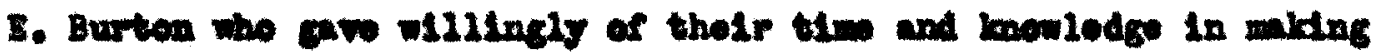

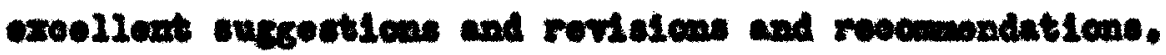

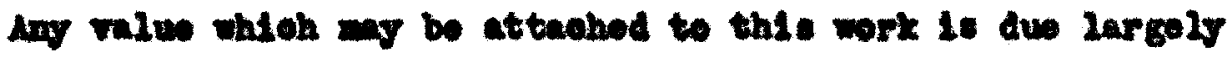

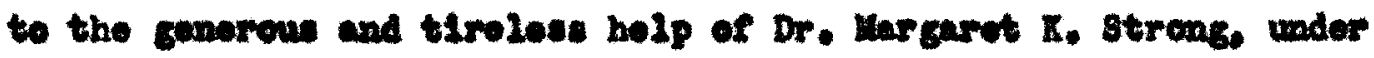

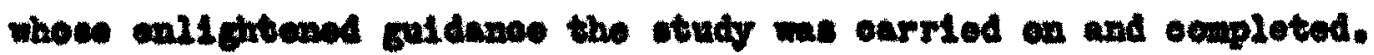

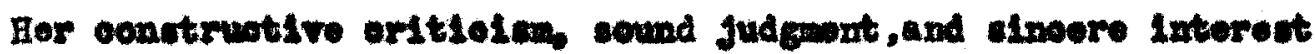
wore lwaye obourecting. 


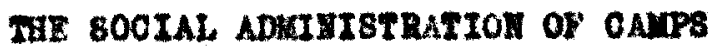

III THE LonIsVILI ARE 
TABLE OF CONTEITS

IXRODFORIOR

1

I. THE CAIPS

8

II. LOCATIOK AID FHXICAL RQUTPIMN

13

1II. EBALT AHD SAPBXI

22

IV. PMRSOMTEL

60

7. PROcRaY

88

VI. ADLARISRRATIOI

163

concLustor

170

BIDLIOGRAF 
INRoDocriox

, 


\section{IMTRODUCTION}

This otudy is a docoription and emlution of twolve organlsa-

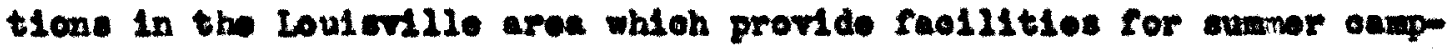
Int. The oviuation has been mado in rolation to moopted sinimu tandarde as oot up by loading authorities for caups oporating on a non-prosit busis.

The purpose of the atudy 18 to chom what loukerlile as a ocar manity doos in eaxplng in rolation to what it may hopo to accomplish.

In the pant fow yoare, the ounping wovement in the Inited states has gone forvard with a grester rigor than at any provious tim in its history. Now Intoreat and aotivity in the fleld aro ovident in all parte of the oountry, and with these has com a better understanding of the opportunities oumping offors for reoreation, odveation, and the oonservation of humn resouroes. We find schools, copporatives, labor unlons, stores, Inductries, and publio and pritrete agonoles reprosentative of overy phace of our natlonal 14 e eponeorling now oamping enterpries. 1 )

The fuot that the Foderal cowernment has reallsed the noed of doveloping a oum progran for a larger number of poople showe a now and wider realisation of the importanoe of campe. Loonl conuuntiten for

1. Salomon, Jullan $1 .$, Camping Irends in Publie Areas, Rationel Park. Serv100, 1086, p. 2. 
for more than a deoade have taken sowe reeponelbl11ty for the camp prom gran. Mniolpal oamp wore estubliahod in ming otates in the 2920 's. Callfornta, In 2886, had fourteen manlolpal oape malutalnod by the reoreationl departionts of olties with the ocoperation of the United 8tates Forectry serviee. Edwotore have realieed that oamplns has corved to dro now ananing to duoation by oporating as a liberalisting and progressite foroe.

Durlas the carly otages of the oampling novement only private oampe for boy wore entablichod, the flrot in 1880. The health. cducatlonal, and reorentional ralues of ounur eampe had beoom co well rooggilecd by 2900 that a wovenont for oumpe for firle was launohod. Sintlarly, the ascoolation of Alrootors of girle' oampe, formed in 1916. followed that of boye' oamps, cotabliabed in 1910.

$A$ camp novemont earried on by the extencion divielone of the acrioultural dopartmonts of collegee and univeralties, In oooporation wth the United state Departiont of Agrioulture, orlginated around 1916. Thoce 4-11 oamps for boys and firle had for tholr ain the dovelopwot of the "hoad, hands, hoart and hoalth."

Publis sohool oampe wore the noxt otep in the developant of thit nowoment. Canp Roowerelt. Chloego's publie sohool aamp. was the P1rat. entablished in 2929. These early aups wore organted on a miltury plan, with omphnets plaeed on phyeleal edvention and rell clous tratning. Spoolal health oarpe for minourlahed and tuberoular oblldren hare, in the mantime, been extabliched in the united states, South Amorion. Corman. Spale and Franee. Uaseachuevtts took the lead in this morom wont in the United states with the 1dea that the oost of providing 
ouporvised outdoin 21 fe for onlldren would be far lese than the oost of intaining anitariun for inourable adults.

The entranes of the National Park servioe Into the fleld wat male In 1034, under the land pregram of the F.E.R.A. The Iand program had for its prinolpal objootive the purohnce of aub-arafinal agrioultural land and 1t: comvereion inte batter use. Forty-alx projeots in twonty-four states wre authorlsed, of whloh thirty-two are belng developed primerily as organied raotion areus. 2 )

Additional national leaderchip in the Ileld hat doveloped from the Amorloan Camplng Aseosition, the Boy Scoute and the Oirl geoute of

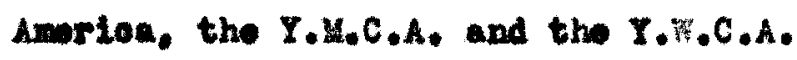

The saot that the Ratlonal Park Sorvioe hes enterod the fleld of aumplng has already had far ronohing orfeot in extonding onmping in

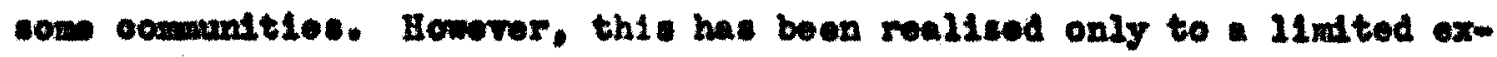
tont in our own commalty. Mr. Lalbort Felr. one of tho carly leadora In the eampling movesont, saye," ... of course overy park and reoreation

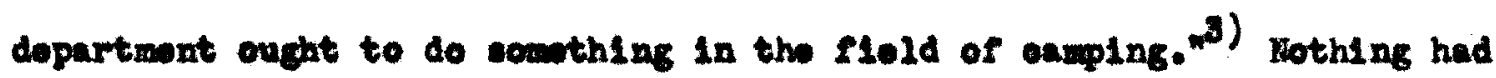
weon done by these departinente in Loulovili prior to the eotabilahmont of the Otter Creok comisulon. Only one representative of the City Reoreation Divielon and one reprecentative of the Loulerille Park Board are inoluded anong the nombere of the comilesion, which is sot up temporar1ly to adiulnlater the Otter Creek projeot of the National Park Service.

2. National Perk Servioe. The Hatlonal Perk Serviee in the Pleld of.

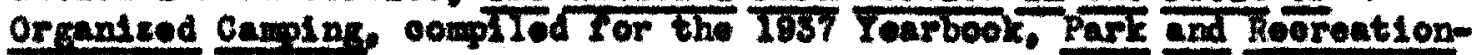
ar Prorose.

5. Quoted from Solomon, Jullan H., Gamplng Irende In Publle Arees, national Park Servioe, 1088, p. IO. 
The only other oommulty agenoy oonoerned with oampine, exolusive of the saspe themelves, 18 the Camp Clearing Complttee of the Counell of Soolal Ageneles of the Louloville Commity Chest. This comnitteo Inoludes representative of the rurlowe oups whioh take the ohildren oent to eamp by the Frosh AIr Fund reprecentatives of the soolal agenoles in the olty whe roopmend the ohildren in noed of oamp; a representative of the Diricion of Soolal Adninistration of the Univorsity of Iouiorilie, and a representative of the city Division of Recreation. A representative of the Courler-journal and the Louiselile IImes is also a nomber of the committeo, we the nowepapers conduot an annual oampalgn for ralalog funds. The ooundtee ate as olearing house, working in 0lose opoperation with the So0lal Servioe Exohange, and arranglng for noceseary elothlng, traneportation, and bolth examinations of ohlidren ent to oamp by the Frean Lr Fund.

The twe 170 campe inoludod in this study are so diversifiod in 1se, adninistration, and purpose that a brief dosoription of each is neceneary for a botter understandlng of thom.

The National Parl sorvice derines Independent oamps as those in whloh indifiduals plan their own activities and provide for their own general welfare. Vader this definition, Jennie Casaldy Rest Cottage and Nount Morey, mation howes for business glrls and wowen, are both indepondont campa.

An organized oamp is derined one in which the oamp as an adminlatrative unlt asenume rull responsibli1ty for the oampors. Carp Gordon and the Volunteer: Camp belong in this oategory, the former organized as a sumer project of The King's Daughtera' junior olroles. The Volunteor's 
Canp is the result of an attengt on the part of the direotors to give underpritlieged girls and boye wation in the oountry. The Frenh Alr Pund enables groupe of underprivlleced young poople to attend, for a period, som of the eampe studied.

Morry Ladges is the eamp organised under the eumer program of

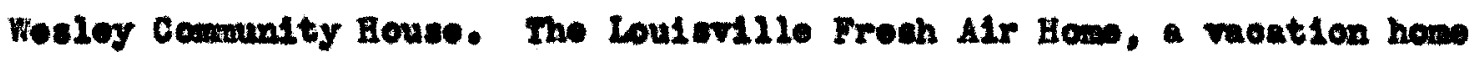

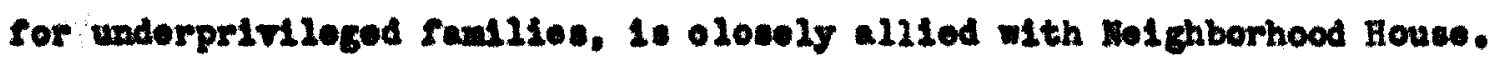
The romainlag oumps, Ohlo Plonlngo, Cholan, Shentituok, Coverod Bridgo Reservation, Dan Beard, and the Canp for Colored alris, would be lloted under the general derinttion of an organised easp as decoribed by the

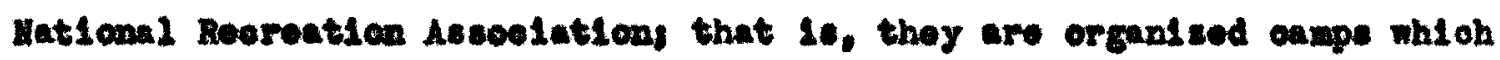
are reaponalbly organlsed and dirooted onterprises for individuals for a perled of uoven or more daye duration, in whloh the prinolpal eoneern is contervd upon porcons and cootal ourtoms, and in whloh Informal eduontion and reorention are bisto objeotlwee.

Cays cholan and was of the other organtatione have weokend oampling for adults. Shantituok and Covored Bridg Roservation have dey

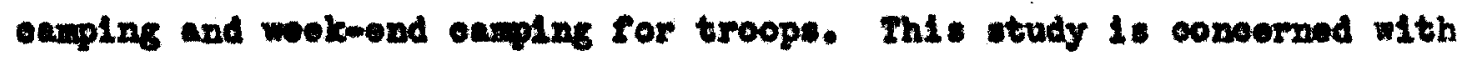
the porlod of organlsed emiplas, thet part of the numar season during which the acup 28 open for a perlod of a woek or more.

The coolal adatintetration of the enups stwdied inoludes equipment, hoalth and cafety, program, porwonne1, and admint stration, all of whioh are intor-related. Who own the oamps and whore are thoy losated? How moh equipent do they have, and how adequate is 1 th Are health and eafety properiy safegunded To what extent has a comprohenalve progran been doveloped? What plans are belng made for the extenalon of the program? 
Are the stafs asbers tralnod in tholr reopeotive fleldet It the admin1otrat1 ve ept-up ati afaotory, and wre wording relationships harmonlous and affeotive? In general, to what extent 1 a the coolal adminiatration

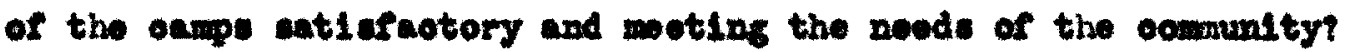
Information on those questions was obtained by Interviewe with

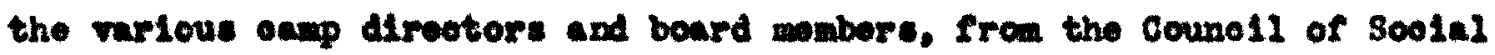

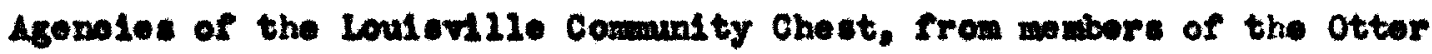
Croek Comalision and the lational Park Service. V1site wore wade to the mjerity of the camps. ceverul of whiob were in operation. Since all of the ongpe could not be risted while in operation, the evaluation noceserrily has ite 11attations. It la hoped, howover, that this otudy will nato cowe contribution toward the Intorprotation and planning of the coolel ednint stration of oump in the Loulevtlle area. Additional Informtion was cooured from the Amorioan Camping Asseolation, National Roorontion Assoolation, Sational Park Bervioe, Unted States Foreatry serviee, and from the boston, the Cleveland and the Paolflo Counolis of seolal Agonotes, also from rarloue publications as shown in the blbllography. 
I. THE CAMPB 


\section{THB CAMPS}

The acoompanylag ohart of the twelve oumpe in the Loulsville area shom wlde divoralfieation of organisation. All of the onmps are loonted

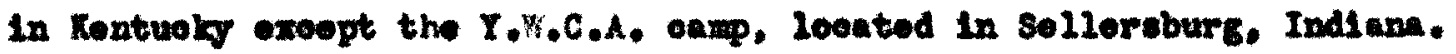
Pive of the campe are looated near Pewee Valley. Kontuoly. wh12e all of thom are withle thirty alles of Loulevil2e.

The name of the omer bontloned on the chart conoted the owner of the eanp 1te. The Y.K.C.A. was the only organisation in 1938 whioh rented the otter creok oamp ste from the Iational Park servioe. The Y.H.H.A. plans to rent sa arva of the slte durlng the 2939 seacon, but the desortpeten of this organization is not inoluded in this study, ac the program plans for the anp are et11 inoesplete.

In som of the onmp. suoh as Den Beard and the Canap for Colored Aris, the owner he no adminlotrative rolation to the oam, as the bulldinge and gromde are rented for the sumer ceasen to the oampe. Howover. in the ance of those omod by boards, such as Jemite Caseldy Ret Cottege and the Loulorille Fresh AIr Bowe, or by 100 al oounolls as Shant1tuok and Covered Bridge Reserration, the ownere have a definite part in the adaindetration of the oampe. When the oamp oun be owned by the organimation whioh adalnicters 1t, better ooordination is $11 \mathrm{ke}$ ly to reoult.

A. ma be seen by the llat of the sponcoring agenotes, all of the oamps are controlled by private organisations, wine of whioh recelve eome money from the Comaunt ty Chot. 
The only organlations whioh have dofinlte rellglous affiliatione are Mount Weroy, whioh is largely Cathollo, and Sterry Lodges, whioh is acrillated with the Vothodist Churoh. Only two of the oume are organIsed for negroes.

The shart reveals that 21 vo of the oumps are organisod for glrle, and three for boys. The remining four are organlsed for both boys and

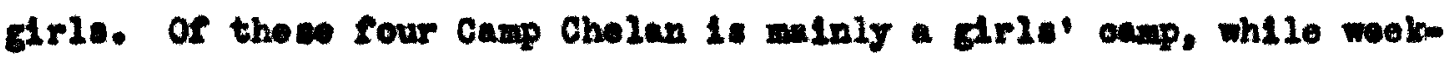
ond groupe ofton inolude both young mon and young wowon.

The age croups di colose that the largent maber of the oamps are organlsed for onlidron, the 21 ittatione ranglng from six to twonty years of age. Cumping for udulte is provided at Hount veroy, Jennle Cacaldy

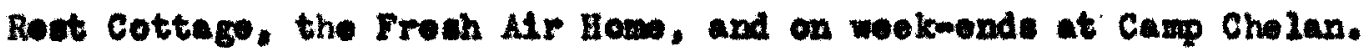
Sesconal cerriees aleo rary coneldermbly, July and Augut belng the wonthe in whioh the largost maber of organisations plan the cumor program of organded ocmping. The organdeatlon whloh own the oump

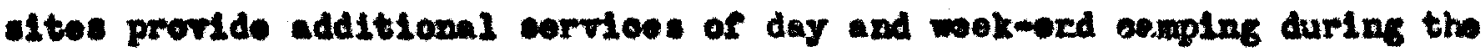
apring and fall wantho.

In eoven of the eanpe one weok Is the average longth of itay. whoreac tho weoke is avorage in four of thea. Ten days is the average 20ngth of otay at Ohio Ploalngo. The chart shows that tho largot aroage is that of Ohlo Plonkago, the Otter Crook Canp, with four hundred and fifty eores, while the smileot is the Volunteers' Camp. whioh had two aores in 1958, and plans to have three In 1959. These factors naturally 1indt the number whioh the oappe may aoocnodate, so that the, onpalty of these oamps rarles from one hundred and thirby-alx sampers at Covered Bridge Reservation to twenty-four at Worry Ledges. 
The Louleville Froeh AIF Howe acoomodated the largest number of Indiriduals in 2838 for the period of organized oanping, and as soon by the shart, Covered Bridge Beservation, Ohio Plomingo, and Camp Chelen nooomodated the naxt largent number in the order 11ated. Camp Chelan hee had a opacity oump overy period for the pest four years. The toe ohargod enmpers also varles considerably. The Loulertlle Fresh AIr Eowe and the Volunteers' Canp are the only camps which do not charge a foe. Appreatnately one dollar por day is the average foe for ax of the camps, while four of tho organisations oharge from throe dollars and flfty oente to four dollars and fifty conts por woek. The tendeney is toward botter leadorship and a better program in those oampe whith oharge a highor toe.

At Covered Bridge Roservation, Dan Beard and Canp Shantituck, abtendanoe is 11 inted to reglotered soouts who are in good standing. The ohart on the following page prosents a detalled analyalo of the twelte camps in the Loulsvilie area in relation to loostion, namo

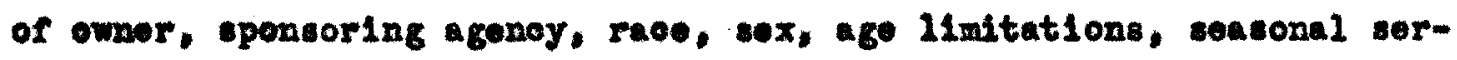
Hoes, arerage length of stay, mereage of site, bapalty at one time, mmber aovomodated in 1038, and the fee oharged.

4. Information conoerning the Volunteers' Camp was noeossarily lindted to that obtained from the looel direotors and the Counoll of Soolal Agonotes. 


\begin{tabular}{|c|c|c|c|}
\hline Dars of Car & Locatron & MATE OF OWIEX & SPONBOntro nonor \\
\hline Ohlo Plontege & $\begin{array}{l}\text { Rook Havon, } \\
\text { Iontreily }\end{array}$ & $\begin{array}{c}\text { Xetional Part } \\
\text { somies }\end{array}$ & 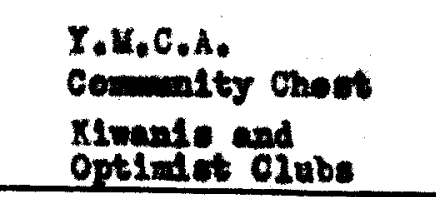 \\
\hline Worry Lodges & Lale Loulevil2 & $\begin{array}{l}\text { Woules } \\
\text { Comanting } \\
\text { Henes }\end{array}$ & 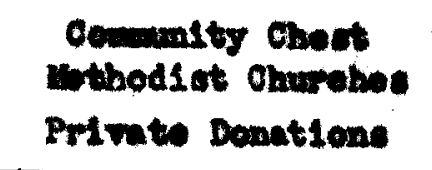 \\
\hline Lowat Uarey & $\begin{array}{l}\text { Powe Vulles. } \\
\text { ronovely }\end{array}$ & $\begin{array}{c}\text { stetoro } \\
\text { of } \\
\text { virey }\end{array}$ & $\begin{array}{l}\text { 810tere of uroy } \\
\text { (Cathol1e) }\end{array}$ \\
\hline $\begin{array}{c}\text { Volunteers" } \\
\text { Cans }\end{array}$ & 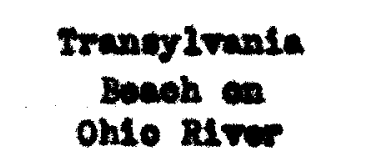 & $\begin{array}{c}\text { Volunteore } \\
\text { of } \\
\text { Aaptea }\end{array}$ & $\begin{array}{l}\text { Tolunteore } \\
\text { of } \\
\text { Amprien }\end{array}$ \\
\hline Den Enard & $\begin{array}{l}\text { Jwoobe Sohool } \\
\text { Earrod oroet }\end{array}$ & $\begin{array}{l}\text { Jeoobs } \\
\text { Sahool }\end{array}$ & $\begin{array}{l}\text { Cownonity Ohent } \\
\text { Eoy Sooute } \\
\text { Colored Dirialon }\end{array}$ \\
\hline $\begin{array}{l}\text { camp fer } \\
\text { colered arre }\end{array}$ & 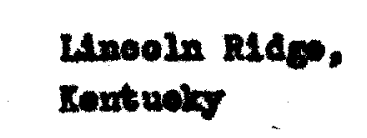 & $\begin{array}{l}\text { unsoln } \\
\text { Inots tobs }\end{array}$ & $\begin{array}{l}\text { Loulorile alr 's } \\
\text { Caup comittee }\end{array}$ \\
\hline 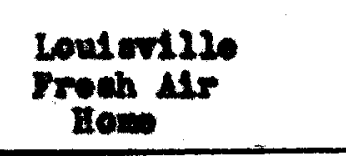 & $\begin{array}{l}\text { Pume Valles. } \\
\text { Ronterely }\end{array}$ & $\begin{array}{l}\text { Board of } \\
\text { Froen } A t \\
\text { How }\end{array}$ & $\begin{array}{c}\text { camints } \\
\text { chest }\end{array}$ \\
\hline Carp Onolan & $\begin{array}{l}\text { Selloreburg. } \\
\text { Inden }\end{array}$ & $\begin{array}{l}\text { Loater121e } \\
\text { I. T.C.A. }\end{array}$ & $\begin{array}{c}\text { Louiswi1le } \\
\text { I.N.C.A. } \\
\text { Commity Chent }\end{array}$ \\
\hline $\begin{array}{l}\text { Cowered Bridge } \\
\text { Recormation }\end{array}$ & $\begin{array}{l}\text { Proapeet: } \\
\text { Setroely }\end{array}$ & 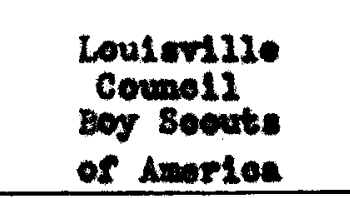 & 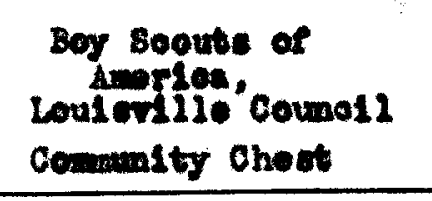 \\
\hline $\begin{array}{c}\text { cars } \\
\text { shanteltuor }\end{array}$ & $\begin{array}{l}\text { 8hopherdevil2. } \\
\text { rontwoly }\end{array}$ & $\begin{array}{l}\text { Loulovillo } \\
\text { ogmoil } \\
\text { ofrise socuts } \\
\text { of Amorion }\end{array}$ & $\begin{array}{l}\text { Loulonille } \\
\text { counoli } \\
\text { airis soouts } \\
\text { comminty Chost }\end{array}$ \\
\hline $\begin{array}{l}\text { Jennse Ceceldy } \\
\text { Rost cottege }\end{array}$ & $\begin{array}{l}\text { Peneo Velles. } \\
\text { Rentusk }\end{array}$ & $\begin{array}{c}\text { Bourd of } \\
\text { Jomite Casesty } \\
\text { Bost Cottage }\end{array}$ & $\begin{array}{l}\text { Protectunt Churohos } \\
\text { Cowumity Cheot }\end{array}$ \\
\hline$\underset{\text { Corden }}{\text { Onan }}$ & $\begin{array}{l}\text { Pewee Vallog. } \\
\text { Kontudiy }\end{array}$ & $\begin{array}{c}\text { Board ar } \\
\text { Jennil Cacesty } \\
\text { Boct Cottage }\end{array}$ & 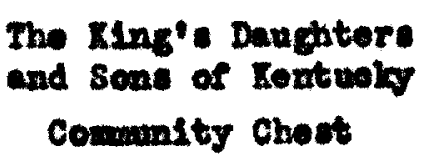 \\
\hline
\end{tabular}




\begin{tabular}{|c|c|c|c|c|c|}
\hline RACE & sex & $\begin{array}{c}\text { ACE } \\
\text { Lrutratrots }\end{array}$ & $\begin{array}{c}\text { SEASOMAL SERTIES } \\
1938\end{array}$ & $\begin{array}{l}\text { Average } \\
\text { Longth of } \\
\text { Stay }\end{array}$ & $\begin{array}{l}\text { ACI } \\
\text { or }\end{array}$ \\
\hline mito & $\operatorname{mat}$ & 12 to 17 & $\begin{array}{l}\text { July } 6 \text { to sopt. } 2 \\
\text { weok-onds Plili, } \\
\text { wLinter, 8pring }\end{array}$ & 10 daye & \\
\hline mite & $\begin{array}{c}\text { Malo } \\
\text { and } \\
\text { Pomalo }\end{array}$ & 6 to 20 & $\begin{array}{l}\text { twooke in Sumuer } \\
\text { weok-ende } \\
\text { way to ootober }\end{array}$ & 7 daye & \\
\hline miste & Ponale & $\begin{array}{c}\text { Student: } \\
\text { oror 14 } \\
\text { ausinose oirlo }\end{array}$ & Jub 18 to Soptomber & 7 day: & \\
\hline Walte & $\begin{array}{l}\text { Yande } \\
\text { romide }\end{array}$ & 6 to 12 & July 1 to september 1 & 7 day: & 31 \\
\hline Colored & Halo & 12 and over & July 26 to August 12 & 7 daye & \\
\hline Colored & Pomate & 10 to 18 & July 25 to Auguat 10 & 14 deye & \\
\hline mite & $\begin{array}{l}\text { rale } \\
\text { and } \\
\text { Paxile }\end{array}$ & $\begin{array}{l}\text { Wothore, babion } \\
\text { and Gisie. } \\
\text { Boye to } 16\end{array}$ & $\begin{array}{l}\text { July } 2 \text { to } 8 \text { soptember } 3 \\
\text { wook-ends } \\
\text { Fall and spring }\end{array}$ & 7 daye & \\
\hline white & $\begin{array}{l}\text { Largely } \\
\text { Poumle }\end{array}$ & $\begin{array}{c}9 \text { to } 16 \\
\text { Tomb wemen and } \\
\text { vefdultal. }\end{array}$ & $\begin{array}{l}\text { July and Augrat } \\
\text { wook-onds } \\
\text { spring and Fall }\end{array}$ & 11 days & \\
\hline Whste & kale & 12 and orer & $\begin{array}{l}\text { Jume } 26 \text { to July } 31 \\
\text { wook-onde } \\
\text { spring, rall and Finter }\end{array}$ & 7 daye & 11 \\
\hline Witte & romale & 10 to 18 & $\begin{array}{c}\text { July and Auguat } \\
\text { wookrends } \\
\text { Spring, rall and wintor }\end{array}$ & $\begin{array}{l}2 \text { perlods - } \\
14 \text { days } \\
2 \text { poriods - } \\
7 \text { days }\end{array}$ & \\
\hline mite & Tomile & 16 and over & Jume 23 to Septomber 7 & 14 days & 4 \\
\hline Wh1te & Ponalo & 12 to 10 & Jumo 11 to Juwe 23 & 14 daye & \\
\hline
\end{tabular}




\begin{tabular}{|c|c|c|c|}
\hline $\begin{array}{l}\text { ACprices } \\
\text { or sITE }\end{array}$ & $\begin{array}{l}\text { CAPAOTIX AT } \\
\text { OMIE IIIm }\end{array}$ & 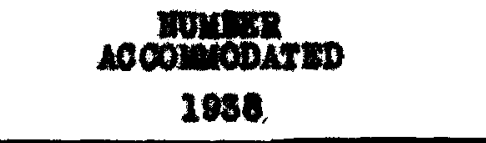 & FEE CAARGSD \\
\hline 460 & $\begin{array}{l}200 \text { anpor: } \\
80 \text { suafe } \\
\text { b holp }\end{array}$ & $\begin{array}{l}424 \text { eanpere } \\
46 \text { itarf } \\
\text { bolp }\end{array}$ & $\$ 16.00$ for 14 days \\
\hline & 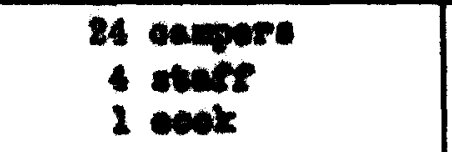 & $\begin{array}{l}92 \text { oanpers } \\
\text { t otarf and volunteors } \\
1 \text { oook }\end{array}$ & $\begin{array}{l}11.00 \text { for boye por wook } \\
.00 \text { for glese }\end{array}$ \\
\hline 11 & 00 onspors: & $\begin{array}{l}190 \text { for portode } \\
238 \text { - wostrende }\end{array}$ & $\begin{array}{l}\$ 7.00 \text { por wook } \\
\$ 1.60 \text { por wookmond }\end{array}$ \\
\hline $\begin{array}{c}2 \\
3 \ln 1989\end{array}$ & $\begin{array}{l}26 \text { saspors } \\
4 \text { hate } \\
8 \text { help }\end{array}$ & no record & nom \\
\hline ? & $\begin{array}{l}67 \text { eampers } \\
8 \text { ateft } \\
1 \text { ceots }\end{array}$ & 185 Individuale & $\$ 3.60$ por weok \\
\hline 4 & $\begin{array}{l}48 \text { campors } \\
1 \text { covemelors } \\
8 \text { holp }\end{array}$ & 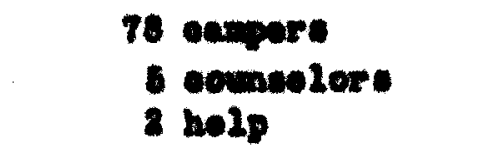 & M.50 poe wook \\
\hline 34 & 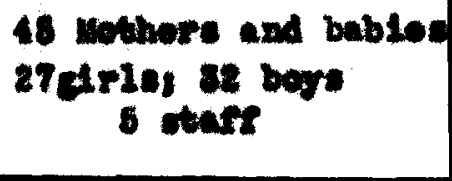 & 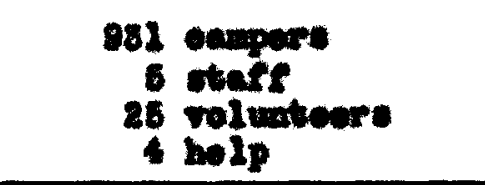 & now \\
\hline 88 & 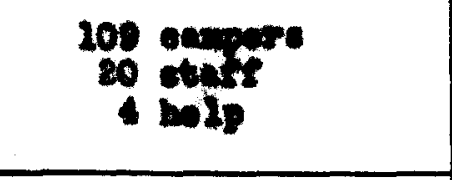 & 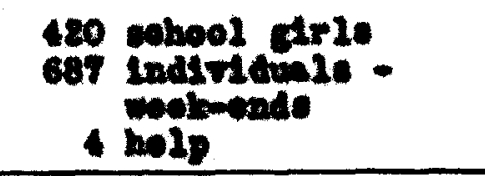 & $\begin{array}{l}\text { \$1.13 por da } \\
\$ 12.50 \text { por poriod } \\
11.60 \text { por wook-ond }\end{array}$ \\
\hline 108 & $\begin{array}{l}136 \text { earpere } \\
14 \text { state } \\
8 \text { holp }\end{array}$ & $\begin{array}{l}608 \text { oanpere } \\
14 \text { tate } \\
3 \text { bolp }\end{array}$ & $\$ 7.00$ per wook \\
\hline 68 & $\begin{array}{l}48 \text { campars } \\
\text { is itaft } \\
2 \text { holp }\end{array}$ & $\begin{array}{l}286 \text { oampers } \\
28 \text { itale } \\
2 \text { holp }\end{array}$ & $\begin{array}{l}\$ 7.50 \text { por wook } \\
\$ 8.00 \text { for out-or-tom } \\
\text { sooute }\end{array}$ \\
\hline 43 & $\begin{array}{l}41 \text { onspers } \\
2 \text { itart } \\
2 \text { help }\end{array}$ & $\begin{array}{l}306 \text { ecupers } \\
1 \text { staff } \\
3 \text { holp }\end{array}$ & 24.00 por wook \\
\hline 43 & $\begin{array}{l}34 \text { sampors } \\
3 \text { stacs } \\
4 \text { belp }\end{array}$ & $\begin{array}{l}52 \text { easpers } \\
8 \text { stase } \\
4 \text { bolp }\end{array}$ & $\$ 3.60$ per mook \\
\hline
\end{tabular}


II. LOGATION AKD pHYsICAL BOUIPIENT 
LOCATION AID PETSTCAL EQUTPUMT

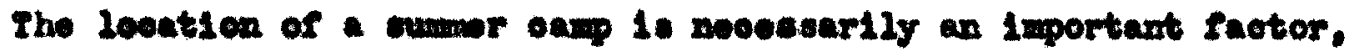
for areund this the progran is bul2t, and the 21 intations of the prowam are condstlood by it. If the grounde are not lookted noar ueablo

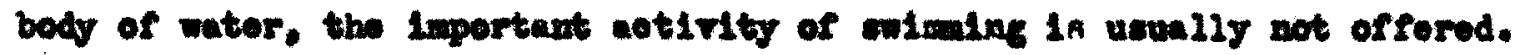

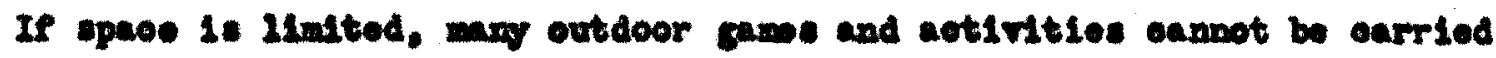
out. If the eamp is leested too far away from a poulated cootion, the 11 ghting, water and eandtary arrangomonte are orten not atidereotory. Intural beauty is an escontilel in erory oap. Privacy from the standpolut of lecation 10 doctrable. The atte is bot loouted at far as is

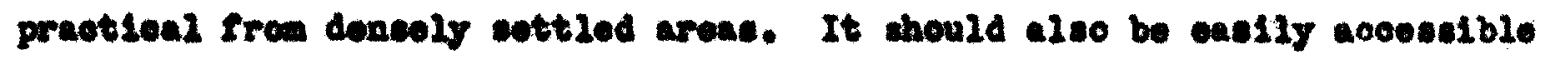

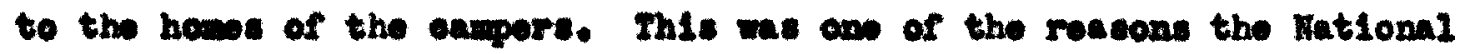
Park sorrioe ohose Ottor Creok for its reoreational projeot, as it was far enough away from Loulavilie, a contor of population, and yot not too far anay to be araliable to a momer of poople.

Adequate dralange for extroas weather 18 oscontlal for 12 onmps.

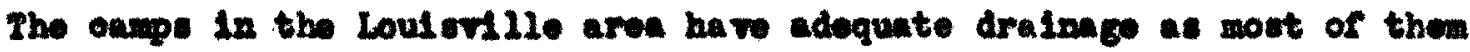
aro ostuated rather high, and thoe whioh are not have prorided mane of dralnage in the aup. At the canp for colored alris, trenohes are dus around the tente for thls purpose.

The loostion and phyaloal foatures naturally rary cooording to the 15e, nature, and partioular parposes of the individual oam. All etan darde agres, howover, that the elte bo troe froa raliroad and trolley 


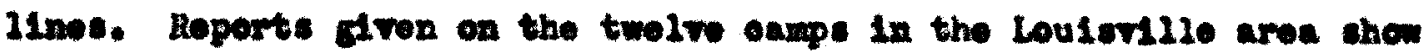

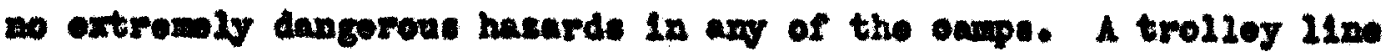
rune outelde of the entranes to Camp Cholen, but at the oampore are not Llewed outulde of the prounde, this should not oreate basurd. The

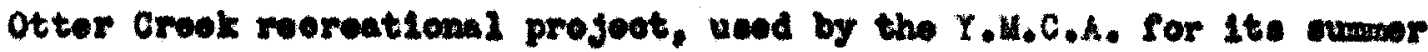
ony in 1958, has a muber of ollfre currounding the onde's aroa. These are cow dictande fron the actual lesation of the bulidings, and campore are allowed to go near this ares only whos nooempanted by a gulde.

In the progren of wot of the oampe in the Loulstile aron, tho

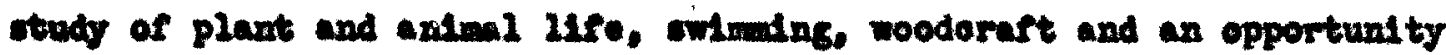
for "roughlng it" are lnoluded. Deneely eottled areac, as well as an adequate body of water are rocdod to earry out woh a procran.

The 100 ation should be large onough to provide an attraotive, coluded arrengonont of bulidins unlte ond equipent, apaoe for a varlod outdoor progrun and exploration, and room for earrying on indopendent croup projeote simultwoonaly. The ong ahould be wo sranged as to

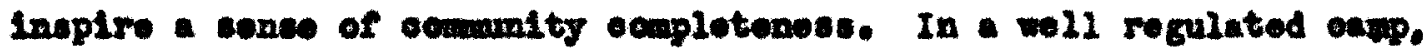
oxpantes of equipesent and the muber of empore w112 not oontime beroad the oupeotty of the stee.

Camp Chelen is looated noar Selleroburg. Indiann, on a thirtyseron aore alte whioh oontalns adoquate play opaos, shade and sunny opotu, and en Ideal lale rod by opring vatere. Boating and ounoe oquipnont are avallable. Tho ground afford aple opportunity for oamp f1ree and mature wudy. An crohory rang and baduluton oourt are furniohed. Campors 1470 in an of three unite, the Camp-by-the-Luke, the Canp-inthe-Foodes or the Cempmon-the-Midge. All oablne are coroened and 
eleotrleally 21ghted. The Bull1tt Rooreation Lodge overlooke the min Iele and is a meting place for the ontlre aamp group. cloce to the ontranoe of the camp are the dinlng lodgo and offleo eablu. othor bulldings inolude hospltal oabln, a platform tudio for morning aceombiles, danolng and dramatios, and a direetor's oubln. A now bout dook 1 belng bullt for use in the 1959 seacou. There are counnelors'

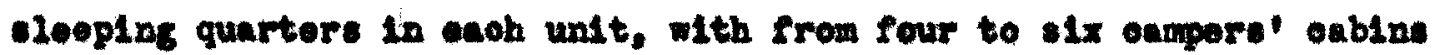
to oach of the three units.

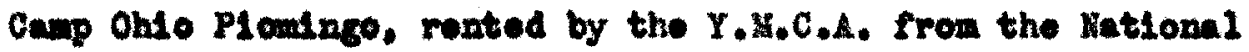

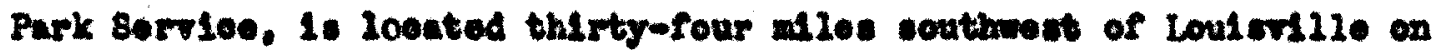

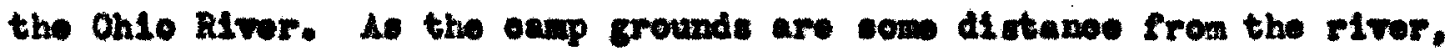
only a Ilatted amount of boating wa provdded durins the 1938 eascon.

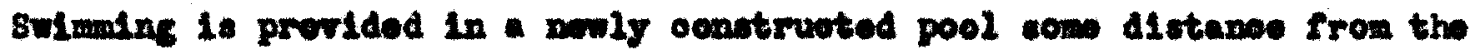

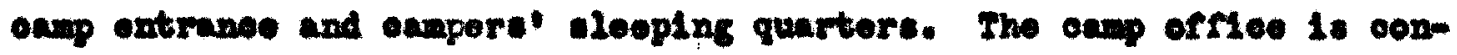
renlenty looated at the ontranoe to eanp, and the dining hall, also uned as a rooreation hall for the owonlag cotivitios of all the units,

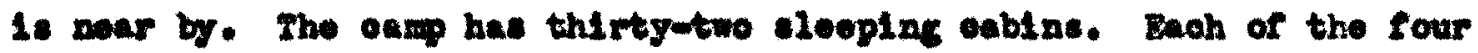
undts has olght oablat and ant lodge ueed for rorention and unit mottinge. There is a latrimo in every unlt, and ono stunted about haif way botwoon the direotor's oottege and the dining hall. Other bulidinge Inolude an Inelrmary, orart whop, nature study shop, emplogees' octtage. and sterage bullding ueed also as fund gator. The apeolous rustle grounds are vory oultable for oamplng.

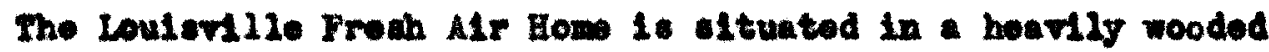
seotlon of ooutry ninoteon alles frem Loul 6ville, in Pewee Valley. The property 1s a thirty-one and a half core tract with a maln building. 
the Uary Parker G111 Cottage for mothere and bables, and four shaoke for older boys. The adulnd otration bullding, soutalning the dining

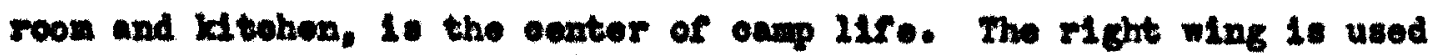
for the drle" eleoping quarter, the ocuncelore and dirootor having rooms to themeltee. Ine boy' councelore have a tent noar the beye' sheake, wth four beds to a tont. The eook has a eoparate room in the admintetration buliding. The oaretaber has a check near on of the

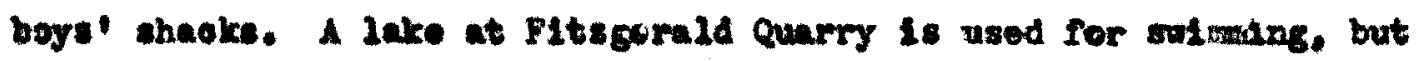
no boating is provided. Although adoquate play opace is arrileble. play equiponm is rathor 11 inted.

Onap Shantituok, the Gr2 soout oum at Shopherderil1e, 18

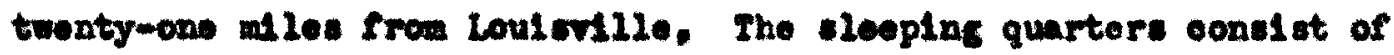
toute with wooden floors. Thove are wosttored throughout the thiokly oovered hills, offoring oampers the adventure of liring noxt to nature end affording pretootion from the ralne. These tents are in groups In ordor that frie who onjoy the same aotiditios ard aro of almilar age my be togothor. The four unite consiot of WLIdernose Int, which houbes

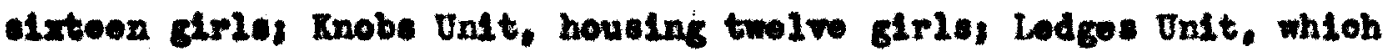

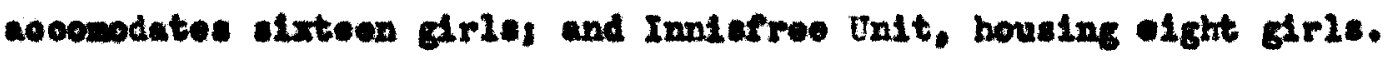
A bullding houcling the dinting room and reareation lodge overlooks the

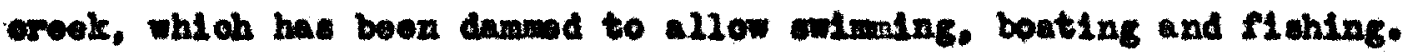

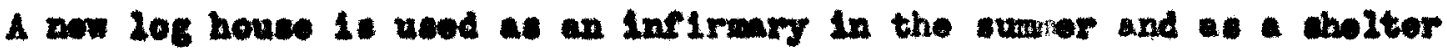
for oupere in the winter. Other equipmoxt and bulldinge Inolude a oraft house, exploration musoun, arohery range, budainton ocarts, bonts, canoes, and doaks. 
Covered Bridgo Reservat10n, the Boy soout oanp at Prospeot. Xontuoky. 18 foumtoon miles fron Loulsvile. Ow large bullding sorves as tho dining and rooreational hall. This is altuated now the entrunoe to oump. Seattered arong tho h111s aro elghteon ourenor absiters and elght winter sholtere. This oamp is alvo dividod into

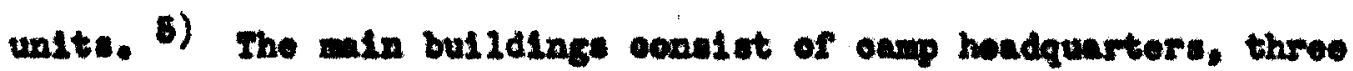
stape shaltore, hospltal oubin, four large tente, a handioraft lodgo and oooke' sholter. There are also a oump ranger's how, a carage.

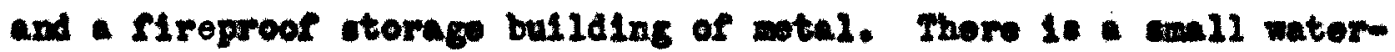
Pront buliding. Boatlng and oanoeles aro provided, and arohery and rlfle range are aruliable. Hature tralle and adequate outdoor play upaes are provided as eseontial to the type of progran offered. Sone oamplns equipaont is mde as a part of the bandioraft program. Herry Lodges, the oamp of Woeley Comment ty House, 18 at labe

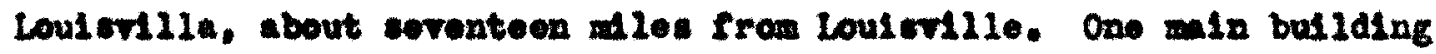
1. used at dormitory, the soreenod poreh of whioh is used as alning ha11. The 1lving room corves as reorestion hall. The play arou outcoore 18 ueed in good wenthor. Thore are twenty-four oote In the dormltory for the owmpors, and four for the teft. swiming and bonting are avaliable at Lalo Loulavilia.

Dan Soerd, the oanp for oolored Boy Boouts, Looated at Harrod'a Oreok just nime miles from Louloville, reports a safe and quiet looation.

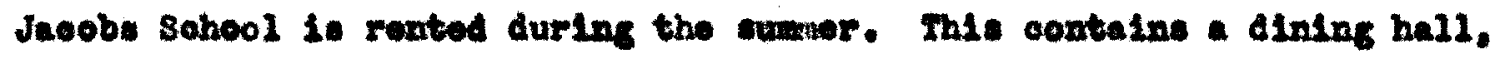
dormltory and reereation hall. Eleven tonts are used as sleoping quarters.

6. For Further cosoription, seo "Orouplng," In Progran nootion. 
Inis losation is only temporary, as the plan to have a permanent site for use during the entire year is under way, and was reoomrended by the Comunity Choot Survey which hes recently been ooupleted. Harrod's Crook is used for miming, but bonting is not offored.

The Camp for Colored Girls also rente sohool, Lnooln Inotitute, et Inooln RIdgo, Kentuoky, twenty-two illes from Loulerille. In addition to this main bullding, there are elvo tents with olght oots in each. Ono tennis oourt and two swings are arallable. Additlonal play space furnl shes opportunity for group gamen. The pool oould not be uned during the 1938 weason beause of dirt washed in by the rlood, but plane for 1ta use durIng the next veacen are being made.

The Volunteers' Camp, 20oatod on Transylvania Beach, has one maln bullding. A large dining room 1s used and soreened poroh with eetenteon cots is used as oloeping quarters for the boys. Fifteon oots are arranged upetairs for the girle. The oots on the poreh are pulled up durtag the day, so that the epase may be used for play in rainy woether. Indoor tollets are proolded, and a large shower in the basement is used by the ohildren. Swings and a trapose are permanent play oquipaent inolnded In the emall outdoor play epace provided. The Ohto River is used for miming and boating.

Mount Moroy is loeated at Powee Valley, Kentuoly, elghteen miles from Loulevil2e. The In sohool bullding is used during the sumer as leepling quurters for the racationiste. This bullding, formerly a oountry rasidenee, also oontaine a dining hall and two large roous in the front whioh are used for reereational purposes during the evoning. The esmpere hare the privilege of mimaing at the quarry of the Louis- 


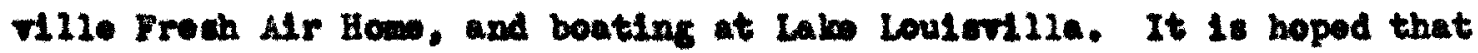
a pool on the grounds w111 bo repalred for une in 1930. Two tonnts courte are avallable, and cow play spee around the bulldinge.

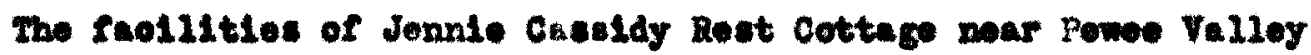
consl st of coe large how, formorly a reldanoe, whioh inoludes the dinting hall and looplng quarters. The simplo furalininge of the ol ght bedroos are malntalned by different ohurohes. Two ono-floor cottages and a reereational hall male up the rest of the bulldinge. One of the cottages is used by the oaretaler, and another oottege of three room

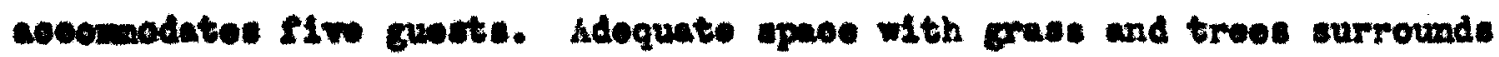
the bulidinge. The min equipmont for reareation is a rudio and plano, eninge, banooke, and a tennls oourt. Tho caupere whe wioh to win hile to Lab Loulovila. Camp Cordon aleo uses this site for the first two weoke in the sumer.

\section{SUMBAII}

Pren the ebove deserfption it is ofidont that only about one-haif

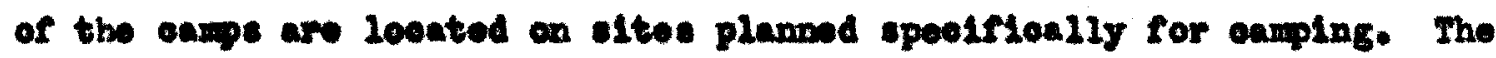
oups whioh are not co altuated oannot ourry out a progran haring so its ball the orledmi objeotiw of eamping: to provide an opportunity for the Inditidual to 21 ve in oommanion with nature and to enjeg Ite untouch-

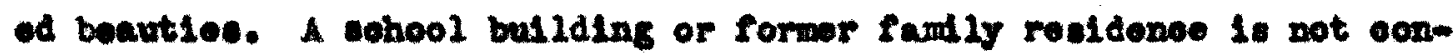
sidered the best type of bullding for eamp bousing parpoces. 
In general the oanpe which have the mots aut table leeation and physienl equipuent for the type of progran veunily carried out in a tumar oum are the ottor Crock Canp. Canp Cholnn, Shantltuok and

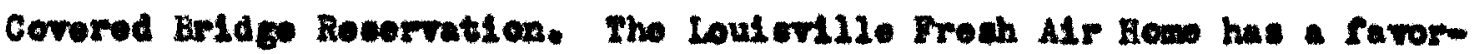
able looktion for a moation hom, but the space and number of bulldInge are 1Linted.

Canp Chelan bes the noot doelrable body of water as it is pritate and largo anough for bouting and the mimalus arou io well plannod and very suitable for teachlng life aving.

Wost of the eampe ire lesated as far at is practionl from a oenter of population. Standarde of looatlon are more cenerally met than thoee of equipwont. Wont of the cape nuet ues the dinine hall as the rooreat10n lodge. The only anp which has a bullding plamod we reareation hall used by the onthe oump is Cholun. 
III. HEALTH AED SAYETY 
IBALTH AND BAPRE:

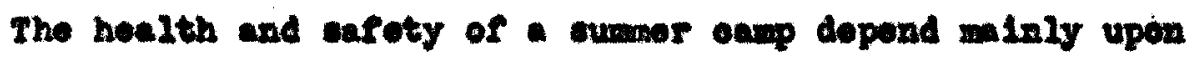
sunitation, mintonanes of hoalth standarde, and eafoty mosures. Inopeotion by a loos or state health departuont is the Aret peosesty In malnteining eanitary conditions. This inoludes torting the water. approvil of mans of garbege dispoenl and of tollet and bath frell1tles. food handilas and othor sandtation requiromonts. Hoalth malntenanoe covere phyeionl exadinatione, nodion otaft and hospltal, and requirewexte for adequate sleep and proper food. Fire and aooldent provention, 21 cheing faosities, the condition of grounde and the waterfront are all fuotors to be oencldered in providing for the enfoty of a oanp. Senteation

The eanitury errangonats of the oamp should be approved by the 10oal or state dopartant of hoalth. Tho stete Health Department of Kentuoly liste the gonoral roguiroments, and although the 11 at 1 not

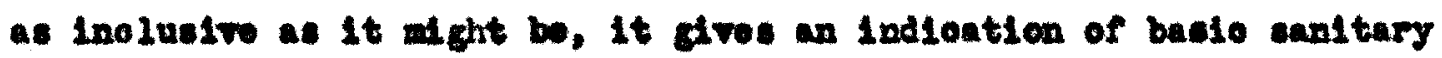
nopde. Thene requl renutite ares

1. A ear and potable water supply.

2. The propor dipposul of wate and garbag.

3. Proper coolding and heating reollities.

4. An epproved inlk oupply.

6. The ellalnation of any Ply or moguito breoding places on the earp prounde. 
6. Solming feclittios, if provided, in acoordanoo wth the requirenonts sot forth by the Awnicen Public Health Aneosiation, and the conference of State Sanitary Bnglnoers.

7. The exoluelon of porsone who have not beon gdven typhoid raoolno within three years, and smll pox racolne. The sohlok test for diphthoria and the Dick test for courlet fover are itrongly reoommonded.

8. In examination of all oooks and food handlers to deternine if they are carriors of any comanicable ds sesere.

1. Wount Wroy, tho Louidille Frosh Air Hone, Jennie Cassidy Reot Cottage and Camp Cordon are In O1dham County, where there is no hoalth dopartwont, they are not under any supervieton as far as inepeotion of cantation is oonoerned. The hoalth and safoty of otter Crook is under the euporriston of the Onlted Stetes Publlo Health SerNoe. The Inepeotion of canttation at Norry Lodges, the Dolunteers' Camp. Dan Beard, and Coverod Bridgo Roservation is oonduoted yearly by the Jerforeen County Health Dopartmont. The Camp for Colored Girlo 18 levatod in sholby County, where there is no hoalth departmont; therem

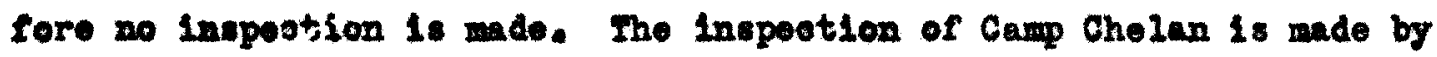
the Indian State Health Dopartwont. The looal health offloer in Shephordarl12 10 responsible for the inspotion of Camp Shant1tuok. Water sepply and Serviees

The water at the camp whose inspection of sanitary condition 1. under the ouperviaion of the Jefferson County Eealth Departant is ntwor takn fien a nomber of the oamp atarf or the oounty inspector) to the state Board of Bealth laboratory in Loulorille to bo tected. A more oouplete examination is made at those oamps risited by the oounty inspoo- 
tor, as the water arrangezents at oxm are Inspeoted as well as the tostIng of water in the leboratory. Only four of the campe reoeive thl Inspotion sorvice from the Jefferson County Iealth Dopartant.

In 2938 anl Inapeetion was mde of Dan Beard by the Jeffercon County Inopector, and samples of the meter wre brought to the State Board of Hoalth. The Jefforean County Health Departwont reoomonded that more sanitary tollots be bullt at Dan Beard as open latrines are used. There wa no roport of an Inspection at Covered Bridge Reservation in 1938, but canples of the water wore brought to the state Board of Ienlth to be tented. Uneatisfaotory sanitary oonditions at the Volunteors" Camp was reported by the Jefferson County Bealth Dopartwont. There 1s no reeord of the water of lount yorey being teated at the state Board of Health. Camp shant1tuok, Jennie Caseidy Rest Cottage, Canp Cordon, and the Camp for Colored Girls cend samples of water to the State Bourd of Health yearly. 8amples of the water at the Loul orillo Froch Air Hom are mbuattod Irequent ly to the state Board of Health during the sumer season but there is no inspection at oasp. The water at Camp Chelen should be teated by the Indiana state Health Departmont, although it has been tested in the past by the Kontuok state Board of Health.

Fountudine or Indiridual oup prorided within oasy roach of all are the safest whods of providing drinking water. Comon drinking rescels are dangerous. At Carp Gordon and Jennie Cassidy Rost Cottage, a olstern with two pumps supplles the drinldng water. Paper oups are used. Camp shantituok provides coolors, oech ohlld having his own oup. Paper oups are provided for risitors. There 18 only one fountain at 
Covored Bridge Reeorvation. Spring wator lo stored in a fifteon gallon recorvolr. Water is suppliod at ohlo Ploselngo by a atroam, and drinkIng mator corvioe is provided by fountalne. Whater is ourriod from the spring at Morry Lodges and pinood in a contalnor with a faupet. At Dan Beard a woll oupplles the wator, and a comon drinideg oup 11 used. A woll aleo wapplies the water at the Cang for Colored Oirle, but owoh

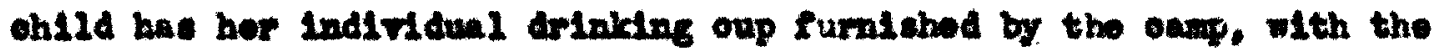
Indirldual's nace on 2t. Wator barrele with aprixe fauoete are prom rided at each of the throe unlts of the Loulevilie Freah Air Home. City water 1s provided at Camp Chelan, and papor oupo are used. Qarbace Dsupenal

Yarloue mothode of garbage dioposal are uned by the oasope in the Louleville aroa. In tho majorlty of the oumpe the garbege is elther hauled away by a nelghbortng farmer or burned. The Loulerille Frooh Air How is the anly organisation whloh reported that the contalners are oouldod artor they aro ontiod. A rogular tim for the oolleotion of carbace is peceseary. Kooplyg the roosptaoles tightly oovered is an additlonal canltary moneure. Sinoe the garbage is not dioposed of da12y In all of the oxmps, this would be destrable oafoguard. The Cleveland

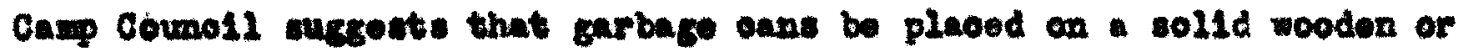
conorete platerorn, raleed a soot above the cround. It 18 also novesunry

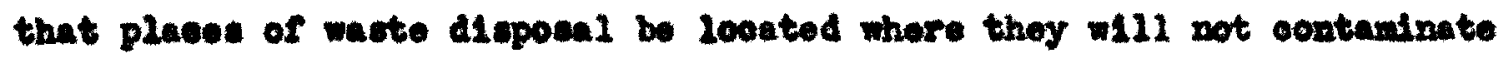
the wator exply. 
ro12ot and Bath Peo111ties

Ohio Plomingo, the Cump for Colorod Olrls, and Nount Horoy are the only oampe otudiod whioh have sluah tollets, the reat of the oampe having plt toliete. It is noosecury that latrines afford Individund privaoy. be covered, and bept in a canitary oonditlon. Senting oapacity of not lese than one undt for overy ten porean is a mindum requirewont. Hand wahlng faelities, paper towele, raning water and roooptaclos are additional noosestise. If running water is not aralleble,

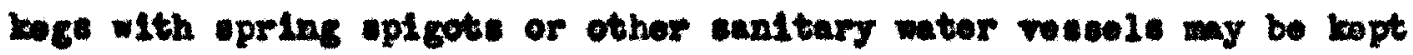
111ed. Seperate 2atrines for ctafe are dectrable. Howover, only a fow of the ampe in the Loulevilie area provide this. Wth the exooption of the oum bullt by the Iational Park SerNoe. the number of showers and batho 10 Inadequate in the oampe. Provision for froquent bathing is dealrable and at lectot one bath wookIy 1. nocessary. One chower to ovory fifteen oampere is miniman. Other Santtary ueavere

the food handisng at all of the oampe is done by cook. This 1. also awong the duties of the dietiolan at the oump whioh ouplog one. The oampere of som of the organisutions also assist the oook or dietiolen in proparing the sood. The food handere at Camp Chelan mat pase rigld modionl exnmination. At Shantituok the Wasserman tect is given an part of the examination for food handlere. Those who handie the food at covered

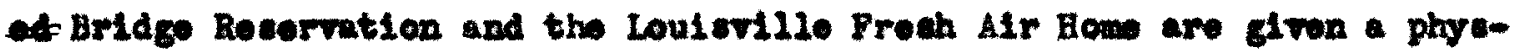
1001 examination at the City Hospltal before eamp opene. Those at the

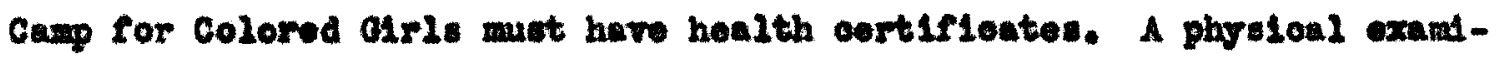
nation is not required of food handlere at Gamp Gordon, Jennie Cassidy 
Rest Cottage, Merry Ledges or Dan Board.

The Cleveland Camp Counoll has set a rory good standard for porsons omployed as food hendlere in caup. The requirements are that nall pereons so exployed ahall be roquired to present a houlth oertirloate whioh ahall inolude oortifleation that they have passed the Waserman, typhone, dipthons and tuberoulin tosts, and if noeessary hav boen fluoresooped. The certifloate is to be igned by a 1100 need physielan who hes ade the examination within two weoks of the date of the oponIng of oamp." 6) It is suggexted that the oortifloates of all food handlers bo posted in a oonmplonons place in the oang kitohen.

At all of the oempe studied the Llah wahlng is done by hand, and dishes are dried with a towel. At nowe of the oampe are the dishos oterilised by any proosss other than rinsing in hot water.

W1th the feots before us, as reriewed abore, it eppears that the Idoal standarde of senitation and inspostion have not been reachod by any of the eamps in the Loulstile aroa, and in som oams oven adntwan standarde hare not been attalnod.

\section{HEALE YAIMTEIANOE}

\section{Phycieal Eraminations}

The firet osential in maintaining health in a sumor oapp is a phyolcal exumination of onmpers and otaff members not wore than one woek before adnision to oamp. An exanination one month before, giving timo for romodial work, and collowed by an examination within a day or two

6. The Welfare Federation of Cleveland, Camp Counoll, Came Standards, 1938, p. 14 . 
of arrival is preforable. In an adoquate examination boulth hictory Is seourad, whioh is uead in the aporrielon, oare, and dirootlon of Individuale at oump. Bxaminetion of ataff mabors as woll ae onapore Is nocoseary both to lesure fitwose for tho ir responelblultios and as protootion agalnat comanloable dicoace. An additional houlth ohook of Individuals aftor arrival at oump is necosengry. Thore is no logal requinowent in tentuoly for hoolth exanlnations of oaspers and stafs mombers.

At Cowored Bridgo Rocorvation thore is a promone oxand nation of all ocupore and staff, a re-oheok by the oang phyololan whop the boys arrivo at oamp, and a ohook whon thoy loave. The atarf at Dan

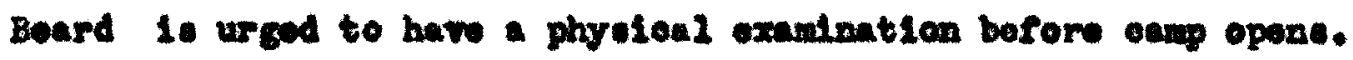
Bach oxmper 1s required to have an examlmation bofore ooulng to oamp. The only hoolth ohook at thls oamp is the wolght nooord takon when the boys arrive, and agein whon thoy loave. Cholen requiros a modical examination of the onmpore andentaff prior to oamp. Thore is a 21mitod Inspeotion of oampere of the nures at thetr arrival, whon the moavures the wolght and holght of oach. An cxamdnatlon of the otaff of shantituok 1s required before oum opone. An examination is required for sampers whthin two weoke procoding tholr arrival. Whon thoy arrivo, a mporf1alal examination is glvon by tho nuree, who ohooks wolght, ikln, theont, oyos, and foot. At Ohio Plomingo an axwmination by a lookl phyalelen is given to all onmers and 1s required of the ontiro staff prior to onmp. Whon the boys arrive, the oamp dootor ohooks further for wolght, skin dieordors, and any physion oonditlone whioh might 11mit notivity 
partiolpation. Every boy 1s walghod before loaving. At Canp Gordon, Jeanie Cassidy Rest Cottege and Mount Moroy, no modioal examination is required of the ataff or of the oumpers. Camp Cordon requires the jarunis to sign a oard freelng the direotor of responsibility for the oh11d's health, and indloating whothor or not the oh1ld is phyoleally able to go mimalng. The Loulerille Freah Air How requires a physioal examination of the staff and an exumination of canpers three days before the opening of the hom, to see if the applioants are froe from infectlous or conteglous disoases and any unfavorable heart condition. The campers are welghed at the opening and elose of the camp poriod.

Thore is a modioal examisation of oampers and stafe two wooks bofore the opening of the Camp for Colored G1rls. The oamers are weighed on arriral at oamp and on the day thoy leave, At Worry Lodges there 1. no nedioal examination of the staff. but one is required of all campers. There 1s no follow up when they errive at oarp. It the Volunteers' Camp, only the welght of the ohlidren is taken before and after oump, and a superfielal oheok of the onlldren's physieal oondition is mede by the direotor previous to oamp.

Hoalth exanination blanks are used by only fire of the camps. These reveal that a far wre thorough examination is given by some than by others. The extent to whioh this information is acturily used in relation to the ohild's aotivity at oum 18 rery important.

The type of Information obteined by the Louleville Fresh Air Home is very genorel. The oampers are instructed to have oard filled out by the fantly phyololan before oump opens. The physiolan is to state if the porson is froe from infeotious or contaglous diseases, and to 
mark the type of axerolse the person is able to take, whether vigorous, moderate or none, Hore oouprohonelve information is inolnded on the health oard used by camp chelan. A very good form 1 s ued for the health record of oblidron cent to the ande by the Loulowille Froah Alr Fund.

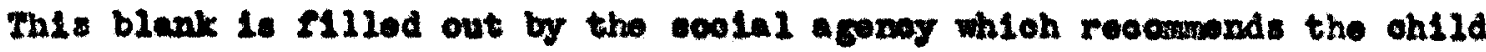
for oaxp. The blanks uced by Corered Bridge Resrvation and Camp Shantituok are exeellent. They Inolude not only information conoerning the oxamination by the physielen, but ale additional information from the parents. Tho health examinetion blank ueed by yorry ledges oelle for Information obtalnod about the olld'. generwl health oondition as It my be affeoted by oamp activity. This axnuluntion is conduoted bofore oang through the eervloes of a volunteer physielan.

In act of the eampe in the Loularille area, the pre-oamp health ohook 1s relatively good, but after the onllaron arrive at oump, furthor

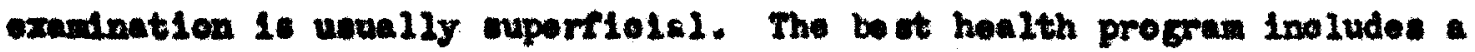
dally inspeation of each easuper by a rogistered murce or phystatan. Whon thia Is not possible, an inepootion overy third doy, by the nuree or physiolan in ohres, and on other days by the oabln oouncelor, who row ports to the nuree, is a desirable aubstitute. Melther of these plens oan be followed in those Loular1110 eampe whloh have no physlolan on the trars.

\section{Median start and Raolitules}

The wot deulrable plan is to have rogistered dootor on the otaff. but whore this 1s Impreotionl, a dostor in the nolghborhood ahould be subjeot to oall. All of the eamps in the Loulavile area wot ol ther one or the other of these regulremente. Inolusion of a regletered nuree on the 
oump starf, to work in oooperation with the rosldent or coneulting dootor, 1. more and more gonorally oonsldorod oswential. It is not intended that suoh a nures be given modionl responslbility in place of a dootor. Fon of the anmp etrudied lnolude such a porton on the otaff, and those whioh do, have the nures in the plave of residont oump phyololen. These oumpe also have a dootor on call. The wot deslrable lnfirmary faolilties Inolude euitable room for booplag Firat Ald and modiond oupplles, for extanination and applleation of dreselnge and treatment, a exparate room and one or wore bode whore enpors on be leolated undor cuperviations tollet, wator, and hoating raollitios. It 1o best for modlond otafe quartore to be in the came bulldeng.

81 ght of the twelve oumpe in the Loulorlile area are without a coparate molleal buliding. Only a fow have quartore for the sodloal otaff In tho cam building. All the camps wet the minimm requirenont of monIng the looation of an coosesible hospltal.

Worry Ledgee doos not have a dootor or murse on the otaff, but a Loulerille dootor is conoulted in eabes of omorgeney. Ae thore is no

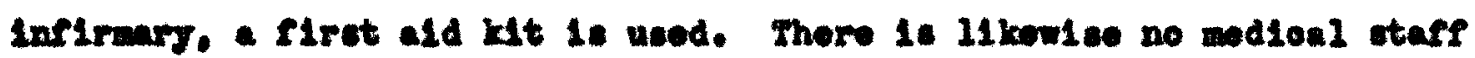

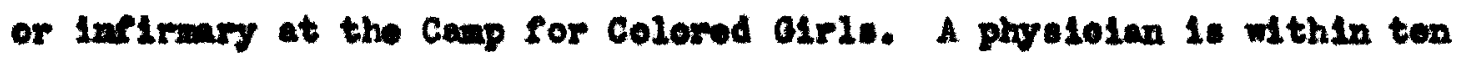
minutes' oall of camp, and a speolal double roon in the dornitory 1s used for 1solation of slek persons. Canp Chelen has a reglotered nurse on the stari, and a dootor on oall ono allo from tho oand. A coparato bullding

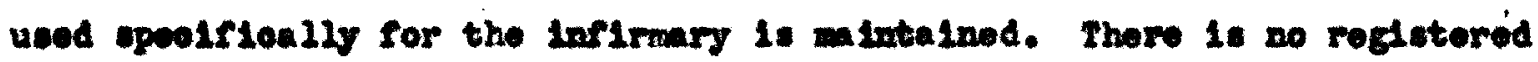
nurse or phyololan on the staff of the Loulswill Frowh Alr Howe, nor are there any separate quartere for the leolution of slok perwons. A dootor I1res noar the oamp, and seme nomber of the camp staff 1s assigaed the 
genoral dut 10e of a nurne, Jennle Cansidy Rent Cottage and Canp Corden have the Pewee Valley sanitoriun nearby for omorgenolos. The medloal oupplies at the howe are not complete, and there is no infirmary modionlly trained ataf. A graduato phyalolen 1s employed on the stafe Onle Plomingo. A soparato ombin 1" eguippod as the hoopltal, and the doctor's sleoplng quartors are in the eam onbin. Dan Board has only a flrat ald kit as molionl aupply, and has a dootor on oull in ouse of cooldents. A group of colored phyaleiane from Looleville who rolumber their cervioes altornate in dally visite to oump to examine tho bogs. At Covered brideo Renervation an interno 1 o enployed and a hospltal malutalned. Casp shantituok malntalne an Infi rawry, has a

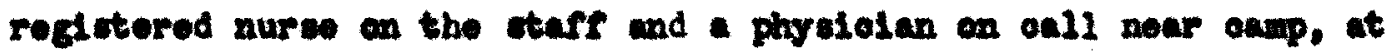
Shepherderi21e. A regiatered nurse who is aleo in oharge of the dining hall is on the stare at the Volunteors' Camp. Although sowe of the oampe do have a modloally tralned otaff mom ber, there 1s no thorouch dulily examination of the easpers. A deliy hyclene reoord of the ghyslolal oondition of onoh eamper lo doalrable. In the oampe whore thore Is not an adequate modieal otaff, the responsiblisty of the oampere' houlth 1s orten loft to oouncolors. Although it

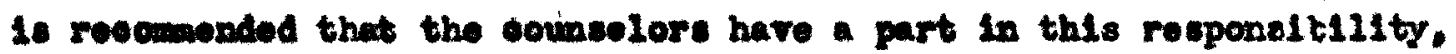
thoy eannot edequately oarry out this duty in addltion to regular oouneolor duties. Imanaseat Lon

The ohlef danger in mont oampe ariees from the major oontugtulas disoasos. It is polnted out that in 1930 ocmparatively fow oumpers wore Immunised againet the disease whloh was then found to be the greatert 
casap houlth hasard, nawely typhold fovor. Iyphold innooviation io inportant, due largely to the faot that thare is littlo ouporvielon of

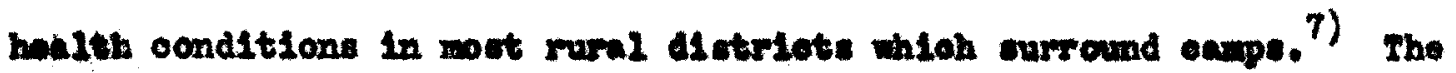

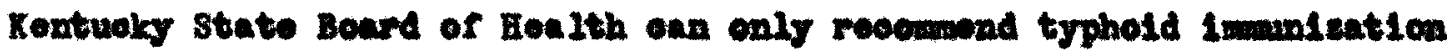
for all oanpers.

Typhold thote are requlted of oapore at Bhunt1tuok, Dan Board, Camp for Colowed OLris, Worry ladges and Cholan, but are not required

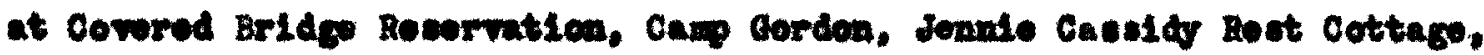

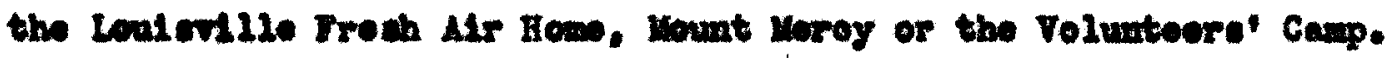
They are roecunonded at Ohto Ptominge. s200p and Bet

The anount of eleop and rost whloh oumpers got is an Important Iten in mantaining boulth. Suffiolont sleop and ront is noodod in order to belabes the progran of rigorous notivitles offered by the mejority of oxups. Standard houre of rest eot by tho malte House Conforones 8 ) arei

Tor the night eloop, ohildron up to the eevnith or elghth your should have twive hours. Botwoon the elghth and sixteonth yoar tho reduotion is houre of sloop at night will vary with the Indiridual ohild, but in cemoral these flgures my be adopted at roachembles

Ieare of Are

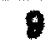

10

11

12

28

24

15

16

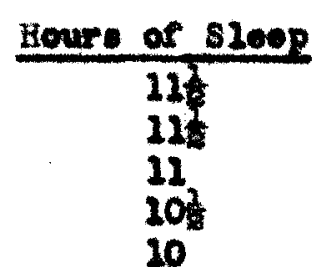

a)

0

7. For further Information wo sandore. J.W., "Safe camp for Young Amoriae," Matlonal safoty Done, 1080. p. 77 .

8. Dimok. HedIfy S. and obhors, Charmeter Benostion in the Sumaer Cese, Honograph III. 1986, P. 2X. 
In addition to the acoptod number of hours of leep at al cht, at lout

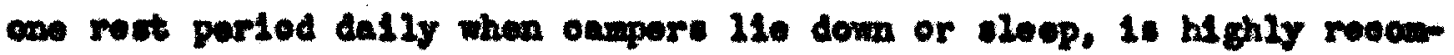
moded. Aotivities at oump aro bually wore ofromoue than the regular cohool routine durins the your. A quilot perlod of from twonty to thirty minutes before male is aleo roedunended.

Oblo Plantrge woots the mow otundards of reat, with a daly roct portod and a porlod of about fortymelve minutes bafore and after cuppor in which thore are no plumined activitles, Ceap Cholan wote the rom quiremute for aleop approxlmately, and that for the dally rect porlode

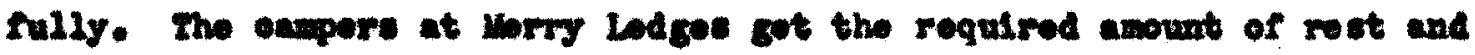

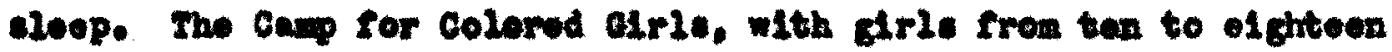

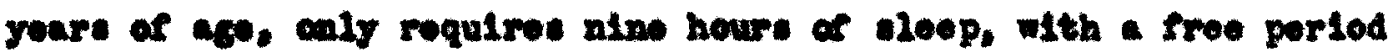
after owery mal and an howe of root artor the noon mal.

At Dan Band the eapers range tren twe 2we years of ago on, and got niwo and coombals hours of leop. Thore is root poriod in the

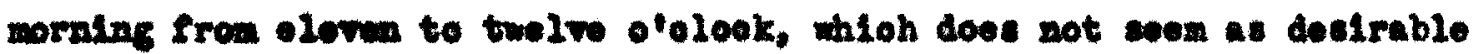
a we Imadiatoly followlng the noon mal. Cam Shantituok and Canp

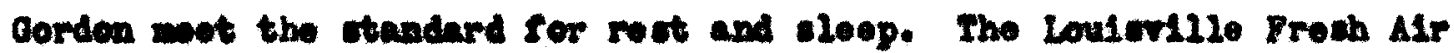
Eon dees not quite reach the otendard for youger anpore. Howewr.

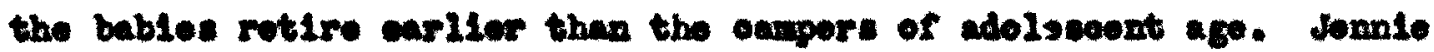
Casaldy noet cottage and woumt leroy have no regulated sohedule of

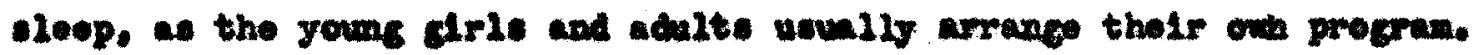

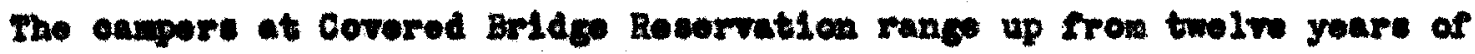
ape. and get but nine howr. of loop. An hous is troe tiwe artor lunoh 18 cinon whon anpere are onocuraged to rest. 
Food

The amouit, variety and quality of food corved at oamp are rery 1mportant in their effeet on the health of caxpers. The diet should be well belaneed and suffiolent in ampunt to woet the requirements of crowing ohlldron. Frooh w11k,9) frults, and regatebles for all onmpers and starf mombers are noevesary, and are uewally assured if a diotiolan 1. employed on the oamp ataff.

In Ion oost oumpe at lount one plnt of milk per person should be provided dalis for bererage purpeses, and dried or clif milk used in oooking. One egG and at least one gonerous sorving of mot, fleh, or fowl por day in mintmen proteln requirenont por poreon.

In 20 oost oumps beans, logunes or obeese may be substituted. Fresh fruite and regetables are preferred. The use of home canned regotables is not approrod by the Cleveland Oamp Comoll. It 16 eseontial that whole grein broud or cereal bo served at leant onoe a day, and if posalble cerved at every moal with white brosd. At least three sorvinge of butter daliy are reoomended. In addition to the roods listed proviously, ample quantitios of oarbohydrates, and sugars malnly in the form of descorts are noodod to provide the adoquate onzorlo intalce.

9. "Pacteurisod milk is to bo ueed if obtainable anywere within a rensomable distanos of the oump, and is to be delfvered and mintulned at a temperature of not more than fifty degrees Pahrenhelt. If parteurised nill is not obtalnable, oraporated, powdored, or milk that is oortifled as moeting all the ctandard requiremente of the $200 \mathrm{~d}$ and state dopartinente of hoalth nay bo cubot Ituted." Miniman standards for Orranised Campe. vatlonel Park sorfice, 1936. 
If nolther a trained nor tudent dietiolen can be ongloged, wome wth sufflolent aloxibility for applloation during eamp my planned In outilno before and approved by a coneulting diotiolen. Efelolonoy 1. attained If rooorde ere lopt of the anownt of rood ueed, the number fed, and the oout por porcon. Adoguate refrigoration is neodod for storage of milk and all other perishable soode.

Corored Bridge Resorvation sorve at least one plat of pasteurised milk por porteen dally. The milk is eent from Louisville by an approved dalry. A detalled man 18 mde for overy soal bofore oamp opene by the dirootor In collaboration with the otenard. Bood for an adoquate diet 1s preserved in a refrigerntor.

Camp Cordon and Jonnie Caesidy Reat Cottage servo a plat of pestourlised milk a dey por pareon, and one ogE orery other day, The other required food standards are wot, with the exwoption of butter. 0200margarine is cerrod in place of thle. Hoale are planned by the house keeper and food pronervod in an 100 bex.

At the Loulorllie froch Alr Bome, Oleomargarino la substituted for buttor, and almost a quart of pastourised milk served dally per person. Frow fruite and rogotables do not arorage a serring day. Wole are plannod by the dirootor and oook.

Camp shantitude arvos approximately a quart of pasteurleod mik, and all othor food ossontiels dally. Kals are plannod by a diotiolan. Dan Beard corme approximately a pint of pestourisod mill per porson, two oses, lnoluded in the oooking, and othor oscontiale daily. At the Camp for Colored alris, the under-nourlahed ohl laren are sorrod an oxtra glace of pantourised milk buloo a day in addition to the pint sorrod 
oweryone dally. Bgge are corved three times a week, and other escentials at leutt once a dey. The movis are plannod by the diroeter. Food is prosomed in a lare oleotrio rofrigerator. At Merry Ladges an extra glass of milk is cerved to the underwelght ohllaren dally. in addition to the rogular pint of certifled adik. Igga aro corred

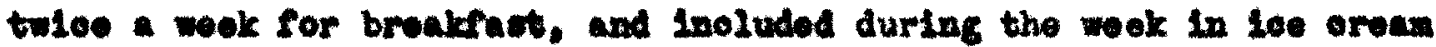

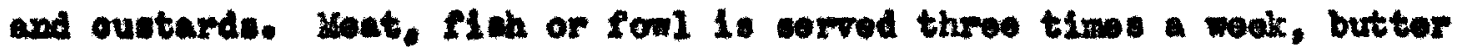
onee a day, and frults. Fegotables and potatoes dally. The direotor of Horry Lodges plant the wals. The food 1s proserved in an 100 box. Camp Oholen has a eradute alotiolan on tho staf, who plant and ouperrines the mpals. There 1s no lindt to the anount of paeteurleed

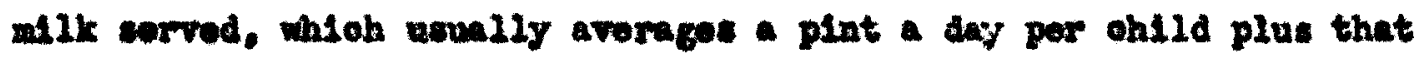

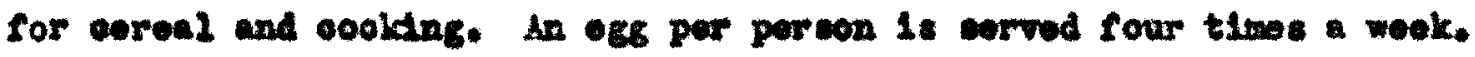
Butter is evrred at ovory meal and whole. whout broed throe tiwes a day.

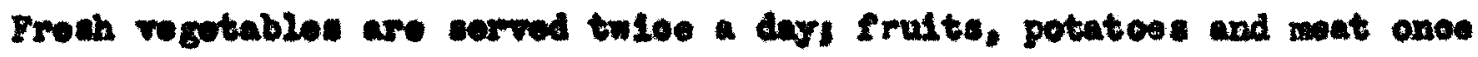
da1ly. The food 10 proserved by refrigeration.

Onto Ploalnge serves an average of a pint and a half of pantourived wlik per porwon dally, and the other eceontlal foods are nerred onoe dally. Weale are plamed by the dletiolan, and oheoked by the direotor provlous to the opening of camp.

This general andyele of foode corved in the varlous oamps showe that the wort destrable ctandarde are malmelnod Cholan, Onie Floningo, Shantibuok and Covered Bridge Reservation, the oamp whioh have trained pereon on the etafe whose oppoifle duty is planesing the mols. It is umeortunate when thls extru burden hal to be placed upon tho direotor, who elrwady has maw other reaponaiblilties. 


\section{SAPBNX}

Ilro-rlohting Equiphet

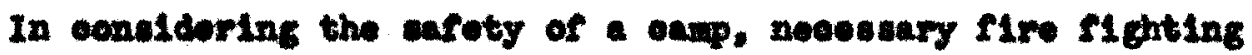
oquipont is ons of the flrot eacentlaie. Loeal authorities my bo

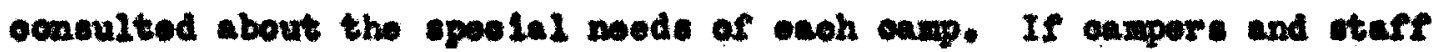
are ramilarised with the prosedure in eace of Hre, the canger is 20esonod. This is partioularly laportant in lare oumpa whore groupe aro arten soattored at the time of enorgonoy. Chendeal extinguliners, palle, hose, rop and ladders ocmpries adoquate oang fire Ilghting

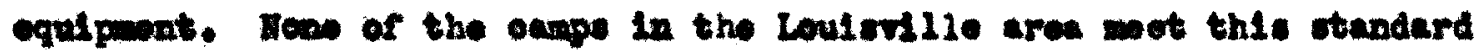
fully. Bebete are the only arallable equipmont at Den Beard. The

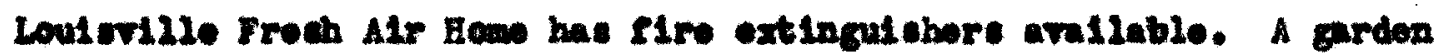

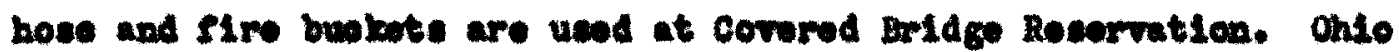

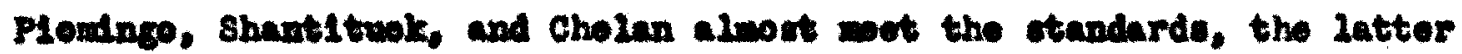

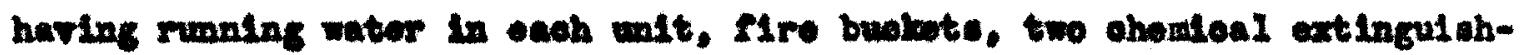
ore and a rool af ilfty soot of hose for enoh walt.

\section{Othor Surctry Lenures}

An addelonal hasard to earety is the feot the man of the oampe

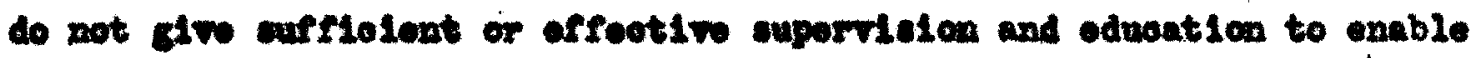

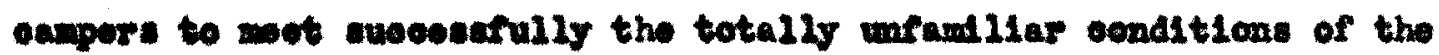
now cavireniont. It is not onough to shom ahlidron reared in the ofty - lear or ploture of polecaous plant and expost them to be adoquately proparod to areld the danger. 10) Careful supervision in the uce of axes and lantro is alwo eseontial.

10. See sander:, J.H., "gute camp for Toung hworloa," Hational sufoty Nowe, 1080, D. 17. 
Few of the Loutorille eampe have inotruetion in aceldont prevarian at a part of the program. Those whloh do, bov inoluded It malniy in the ectivities of woderart and nature erart. Saroty lnotruotione at

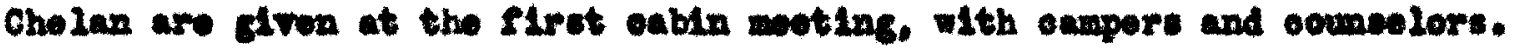
All of the eamp have regular hotare for owlwalng and the cangors are not

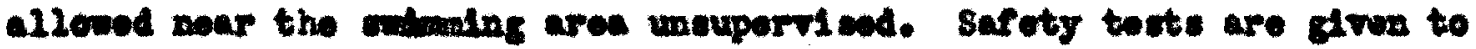
the Boy soouts and Airl Beouts as part of the morlt badge gratem. It

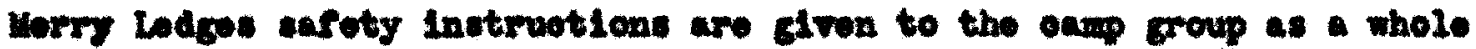
the Plrot night of oamp. Seas earoty inatruation at Ohio Ploningo is

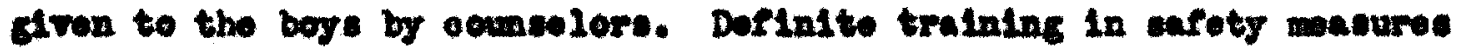
1. Laokings howover, In all the organdentsene with the exeoption of the Soovt canpo.

In ores that the oug olte wy bo froe from hasards, a rogular

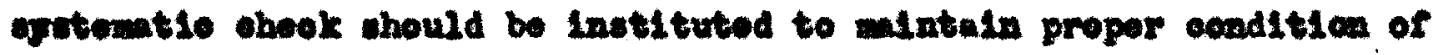
the oum ground and nolghboring territory need by oavipers. J.I. Sandere found that one of the greateot nooldent haverile in mots of the oange ctudied throughort the nation, was the rery poor eandition of waln

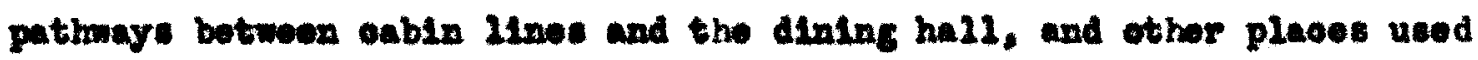
oontinum $22 y$ durlag the dxy and after dark. Good eamp mangenont would

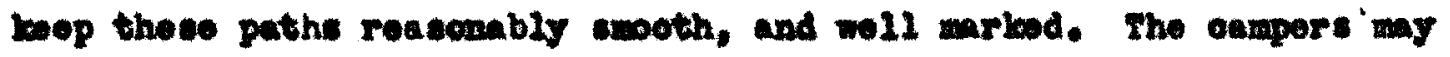
well have part in this care of the gromes, thus eliminating oxtra oort for the earp and engondoring prlde for the onmp apperanoe in the hant of the oampor.

The bulldinge and grounds at Ohlo Ploninge are oleaned dally with tho holp of the ouppers and tho atrotaler. Throe thonsand sores of nalghborlng torritory are used on hikos. The tralls are ahookod for 
wafoty macurses. The nolghboring torritory of cholen is used only we a bridle path, and It ohooked for vas. Shale pathe are used in oamp. At Worry Ledges the canpors take turne inlly in oloculng the grounde. the handyman at the camp for colored olrlo oloune the bitohon dally.

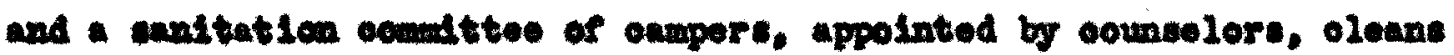
the cround each day. The roadways are partly conorote, partly cravel, and the rost dirt pathe. The oloaning of the bullding and grounde at Dan Board 1s doss wory day by the onupore. Thore 1s one gravel road at tho odge of oampl all the othere are dirt patha. The nolgeboring torritory of casp shantituok is rugeed and wotovohod, and is uood by

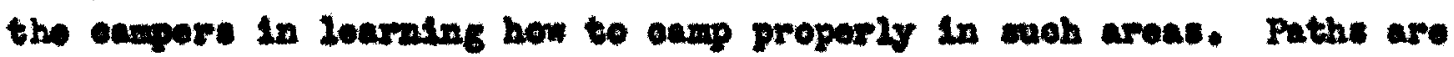
weed in the oavp. Tho oloanting of the butidinge and croumde is porformed dally by carpore who tale turne at thowe duties. The Loulorill.

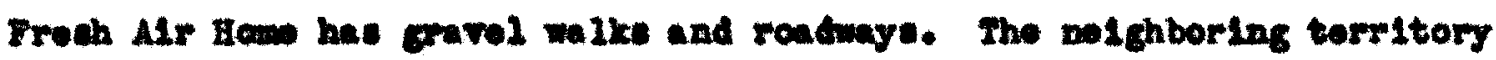
10 not weed. The earetuber oloane the bulldinge tudoe a day, and the ouspers oleas the groundo every morninge the Bourd of Jennte Cassidy Bost cottage reallees that the pathe noed to bo laprowed. The bulldInge and cooveds are oloanod by the earutaker once a wooky the halls, porah and kitohen are aleanod every day. Covored BrIdgo Roservation bas a grevel roading loading to oam, but the rest are tralle or foot paths. The bogse have "fatigen duty" owory day, when the pathe are "polloed" for paper and debrils. The oumpore mop the Ploors erory othor day. 


\section{Lating reatities}

Wichting fealitties are an important factor in oculidering

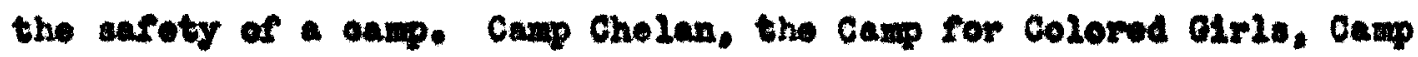
corden, Jennie Canuldy Reet Cottage and Mount leroy have eleotriolty

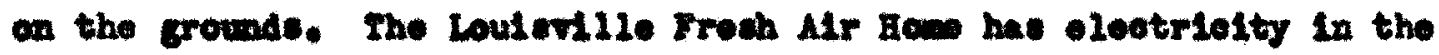
Adulintsortion Buigdins and in the oottage for mothors and bables,

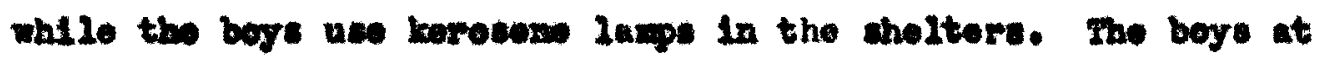

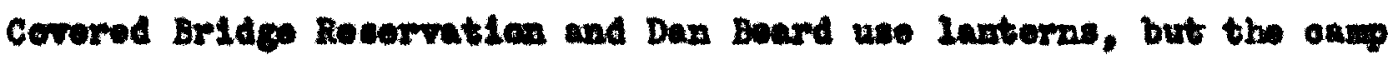
has eleotrielty in the dintre hall, otapf and oook' quarters.

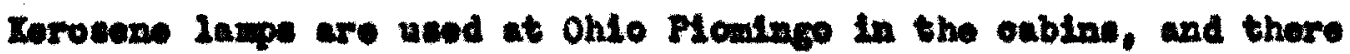
are eleotrlo wires on the grounde. Caseline lamp are used entirely

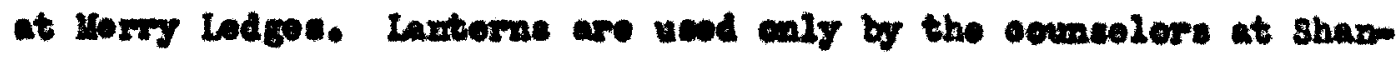

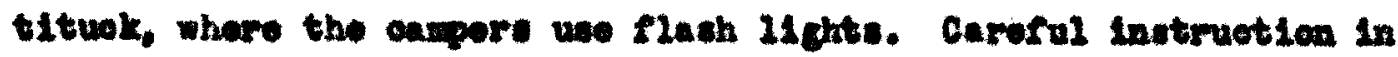
the proper ues of lanterns is a noosstby in these oupe whioh do not have eleotriedty.

Intererout

The matertront is probubly the wot Importent problen in the

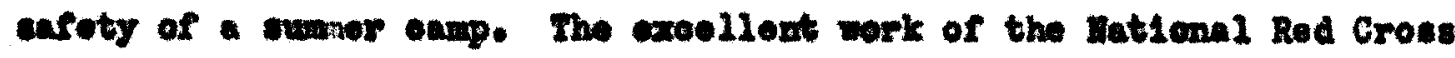

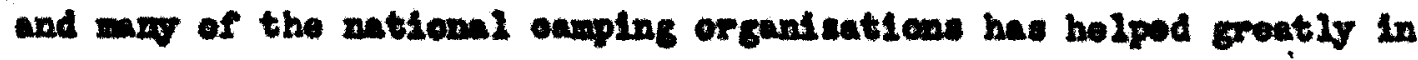

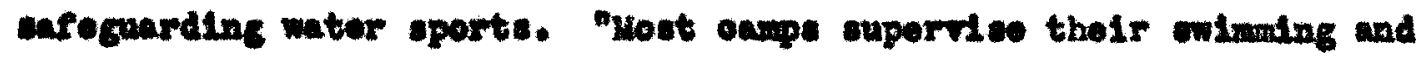
boating feollitle far wor Migorounly than do wot of the oownorolal boaches and pools, so that it is probubly true that oup awluning is the anfest ontuning wont yougatere lnow. Bven 00 , there has not been

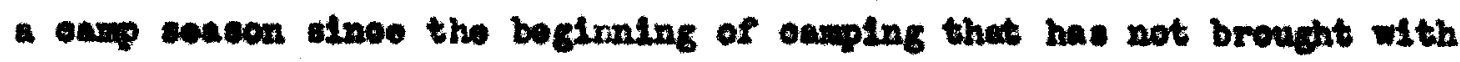
1t a nedlose number of water fatellthes." 11 )

11. Sendore. J. . . . . 01t.. P.77. 
The Uatlonal Red Cross ba sot up in extall standards for waterIrom proteotlon. One of the min reguiremonte is that the bathing pleoe be ohowen to comblne, If posible, doep water wilming for the exporlonoed swinors und bhallem water for beglnnors. These arous

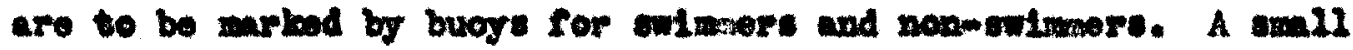
tower olght to bulve foot high 10 nooded on the shore, so oreoted as to overlook all areas of the waterfrent. It is ongseated that ring buers, water glaseos, strot ald oquipont, grappling irans, and

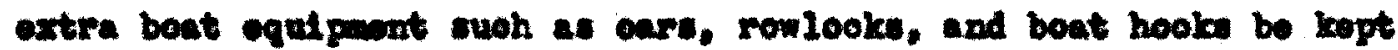
roady for inctent ues. If rombonts and ospoes are used thoy mut be

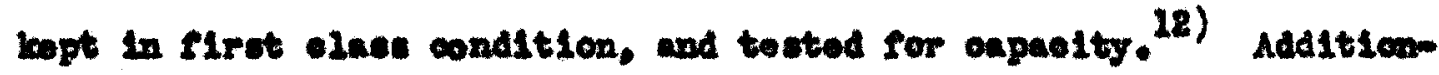
al dotallod reguletione for operating a enfe waterfruat are clven by the sworloan Red Cross. and are rory holpcul to oamps in sotting up a wateront aros.

One of the not offeotlve wothode for proteoting groupe of bathere during wiming perted is the Buddy sycton. The bathere are divided Into peirs, ewery buthor herlag a water budd in his own oless or grade. The buddies are uniming partinore, onterlng and learing the water togothor. A ohook ayctom, whoroby owery bethor has a nubered tag whioh he turns over before enterlng the water, and again upen leaving the waterfront, 18 an added enfoty deries for enfety.

8tandarde for waterfromt otaff lnolude proviclon for at lant ono

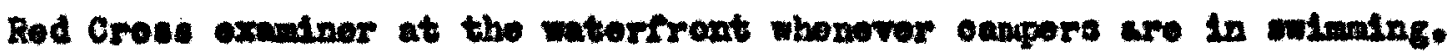

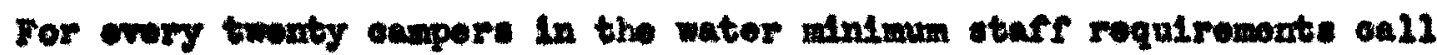

12. Amerloun Rod Crose, "Waterifront Proteotion For Summer Canpa." 
for at lesut two counselore, on of whom has a sonlor Red Crose ilfe caring omblem. It Is adrisable to have addtlonal guards stationod at strategle polits in order to insure effleient guard sorvioe. ${ }^{13}$ )

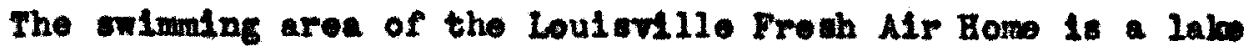
at Fitsgerald Quarry. It is dirided by ropes into ahalion and doep areas. Inner tubes painted white serve as floats, and there is no diving board or tower. The Buddy ogstom is ueod and no night owims are permitted. In 1938 the waterfront staff consicted of one youns wowan and two young won who, although expart sulmers, had not paseod the Red Cross oxamination. The waterfront direotor was ovor twenty yoars of age, and one of the staft guarded while the other two intruoted. Campero wore olaselfled as to eniming ablilty, and were only allowed to swin at reguler times under the superviston of the otafe. A flret ald ldt was the only 11 fo safing equipanent arallable. It Is hoped that additionnl equiprent w111 bo obtalnod, and that the oheok oycter w121 be used in the future. The waterf ront staff should take advantage of the Ilfe saring courses offered by the Rod Cross overy jear. The eampers at sount lerey have the privilege of ueing Fițgerald Quseng for miming.

Earrod's Creek is used by Covered Bridge Reservation for minateg. Separate areas for swlwnore and non-minaers are mariced off by buoys. A diving board and high tower. used for guarding purposes, aro looated at the ten foot depth of water. Throe 11fe boats are lrept on duty during the owluning poriod, and four ring buoy are arailable.

13. See "Epodalized Personnel" In Perconnel cootion. 
Fifteen row bonte and four canoes aro ueed, Tho Buddy and ohook

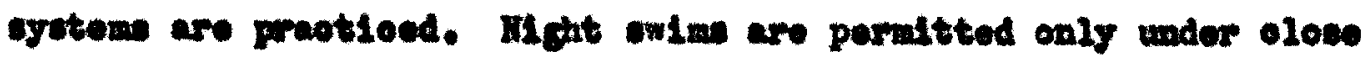

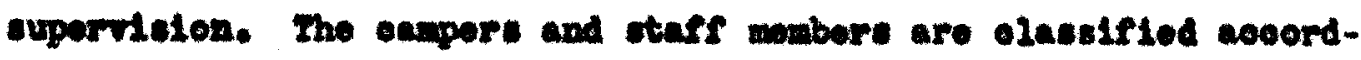

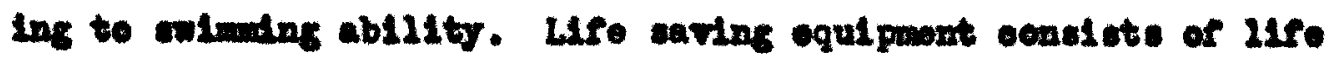
ringe, crappling Irons, firat ald blt and blankote. Lant sonson the waterfrout director, twoatyutwe years of age, was a Rod Croses examinor. Hit two analotants had aod cross conlor badges. Tho necoseary saterfrout regulatione were enforood during the sulm ming and boating porlode.

A oreok at Casp shoutituok is markod into aroas for animors and nop-mimmore by buoys. Plans are belng made to heve orib bullt for beclnoore. Two rloate and a dirlng board aro used. About twelve row boats and two oanose are arallable. The oampors and itafe mobore aro olacesiflod avoording to onImulng ablilty. The buddy and ohook ayotose are followed. Wro eaving oquipeont

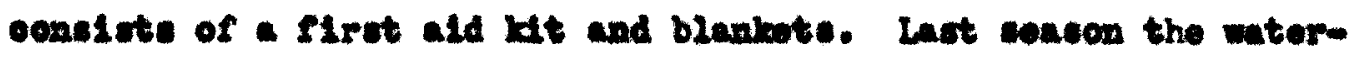
frout dircetor, an exumleor twonty-four yoars of age, had two aselotante over twontymeno who had paesed thoir Red Crose oxamelna-

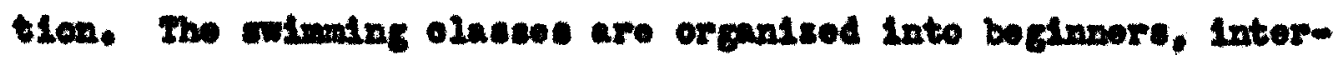
modiato, and advanood, and no night owles aro pormitted. Other onimatas and bonting regulatione are enforeed during the porlode. Den Beard aleo ueos Earrod'e Croek for ite oulming area.

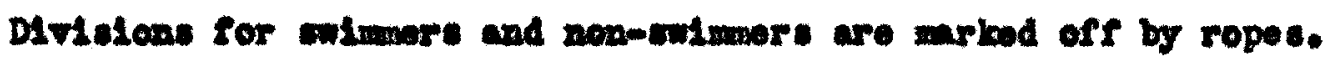
Thore are no boate, Iloate or towors. Campere and etaff are rated

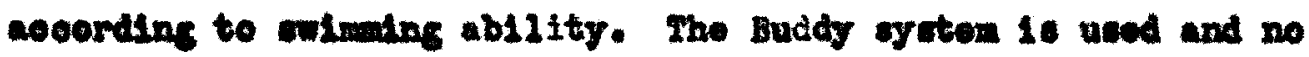


n1ght owime are permitted. The watorfront otaff in 1938 cons1etod of a oren of three or four Eagle soouts who had pasced tholf Junlor Red Cross tost, and the waterfront direotor, who was twenty-three years of age. The water-front safoty may be improved further in the future by Inetalling the oheok syotom, and by addition of life saring oquipmont.

The Camp for Colored Oirls was not ablo to use the pool in 1938 as the tlood wabhed dirt into the reserroly, but plans for 1te use in 1039 are bolng made. No1thor the Buddy nor ohook ayatem have forworly beon ueod, but 1t 1s hoped that thoy will be in the future. The watorfront otaff usually conalate of three porsons, one who has paseed a Rod Cross senior oxamination and who is at leant ninoteon yoars of ago. Only ton ohlidren are allowed in the pool at one time. Since no $11 f 0$

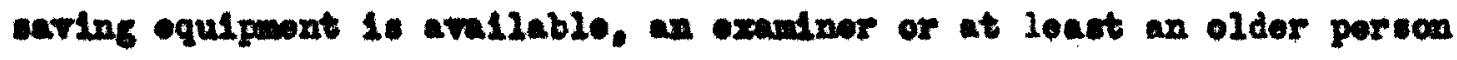
for waterfroent direotor would soes dosirable.

Casp Chelan has an exoollont oniming aroe in 1ts 2abo, whloh 1. eeronty-five by one hundred foot. A beldge diridos the orib for the nox-minaners from the area ropod off by buoge for animnors. The rost of the lake 1s uned for boating. A float and diring board have been bullt. A tomer on the dook is uned for grarding, as 1s the slont

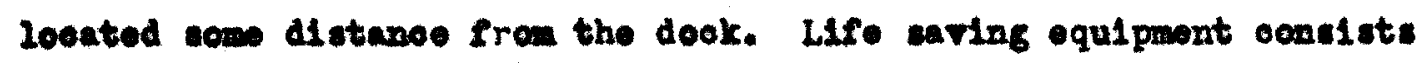
of an unoquipped 14fe boat, two ring buoys, flrat ald k1t, extra oars and blankote. There will be two now onnoes in 2939 in addition to twonty-two row boats and ono oanoe formorly arailable. Campors and etaff mobors are llated aocording to awiming ability, and the Buddy systom 1s uaed. Might oulin are pornitted only for adult: undor super- 
IIs10n. The waterfront ctaff 1s ocmposed of elght mombers. The direetor is thirty-three years of age and has an exuminor's certifloato. Soren persons tho hare paseed the Red Cross rentor 1ife saring test asgiot the waterfront director.

Ohlo Ploninge utes the pool bullt by the rational Park Ser10e. The watemeront direotor divides the pool into arear for awlmors and non-walnmore durlng inotruotion perlods. The Buddy yotem is alroacy in praotiee, and plens are belng made for the

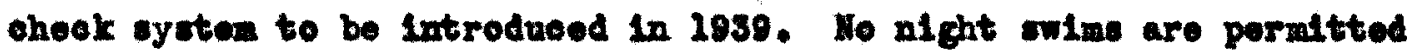

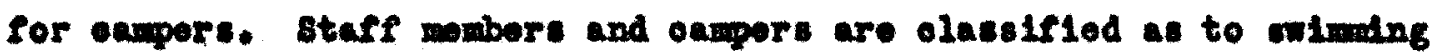

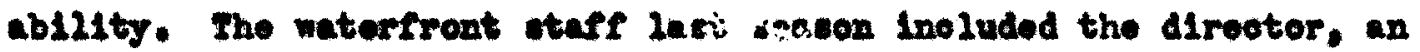
exaretnor twenty-three years of age, four guards, and one othor instruotor who had pased the Red Crose sentor exantuation. Hif saving equipment consiets of Ilfe rings, firot ald kit, and blankets, swiwining regulations aovording to the Red Cross standards aro oarriod out. Morry Ledges, Jonnie Casaldy Reat Cotstage, and Camp Cordon pay for miming prifilege at Lake Loulevilia. Morry Lodges is looated wore elosely to this lake than are the other oups. The sise of the 2ake 1s one and threo-fourths equare miles. The aroas for onlwerese

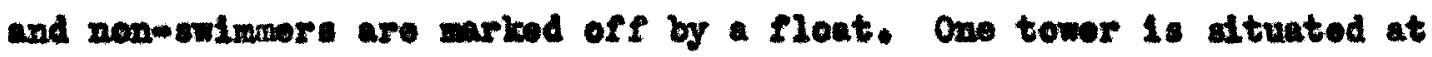
the end of the board walk, and one 1ife boat is avallable. The Buddy aystem is used. One guard and one instructor who hate passed the Rod Crose entior exanination are on duty. Iwonty to thirty row boats and twelve eanoes are arallable. 
4 prive endmatas area wald probably be more caltable

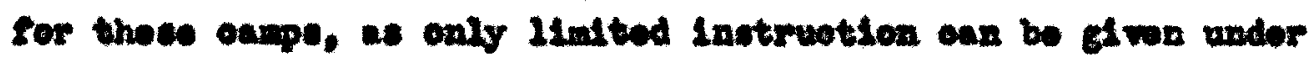
the olrounetrunoes.

\section{sonnurx}

This wootion thowe that the attontion given to boulth and

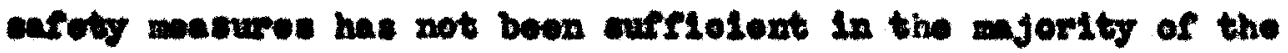

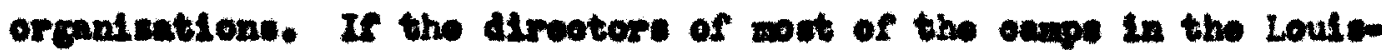

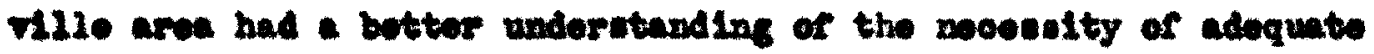

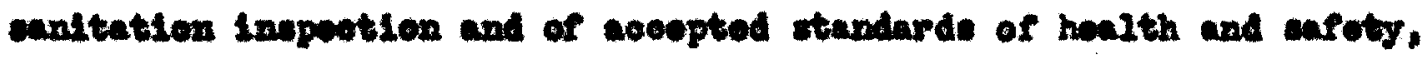
the andtary arrangunate of thoce anges would bo Inproved and anore attention would be gtwen to propor mater and wik supplles, garbage

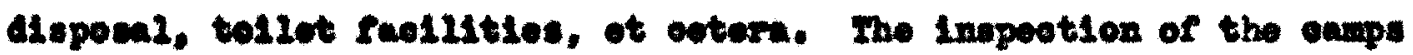

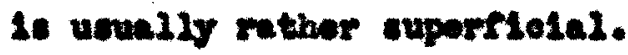

Although the Alet is adequate in wot of the oamps, only a fow of the organtentione have tralnod detiolun on the stare. Thore It no ladioatien that houlth oxudinatione aro roquired of oovk and food huralore in som of the onupe.

Gonrally the otandarde cohlewed in the health malnteaines of eampors are bottor than thowe in exptetion, although the molloal

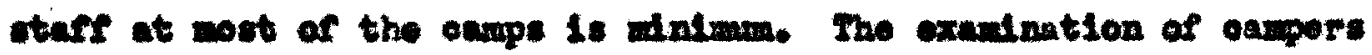

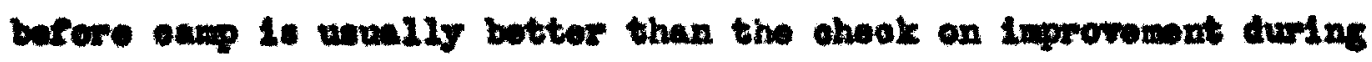

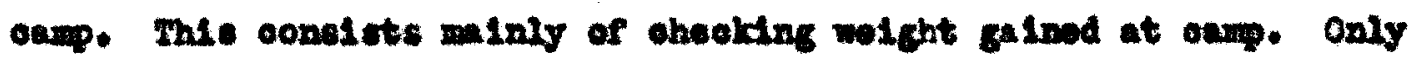
goup of the acepe in the Leutoville aren have a soparate madienl bulldm 
49

Ing, Ne, Ohio Plondngo, Camp Ohelen, Shantituok and Corored Bridge Roservation.

The earoby meagures of wont of the oamps are ouporfielal, with the exooption of the matorfrent. Hore thorough training reguifresonts for waterfrout otaff mombere and better 118-earing equipwont aro

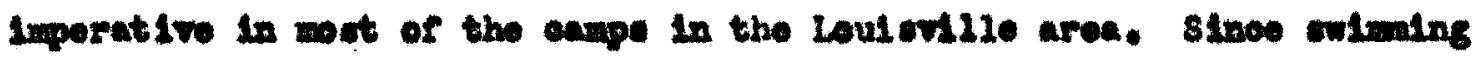
1. wah an inportant activity of oamp 21fo, It is wat grobable that oamp dirootore will realles the neod to drencthen this phace of the camp in the ruture. 
IV. PLesomeL 
FBRSOMEL

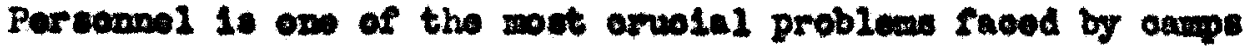
today. To a large extent the type of porsanind deternines the bype

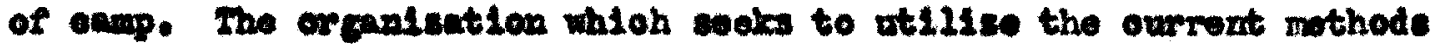
of odvoation in 1 te procrene met woowe leadorshlp oquippod for woh a talk. It 10 astonishing to Iind that sow agonoles sot up primarity

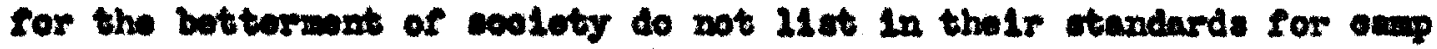

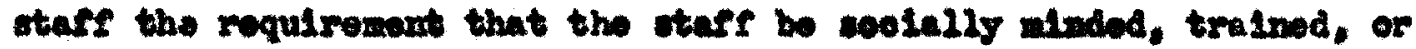
oven Intorveted in soolal movenonte. Not only is the guality of leadershlp laoking but also the necessary specialized training.

Dow sohools arfor courees portelnins direotly to onups, and courwe suoh to group work are coldon talon by Individuala oonsidoring poeltsoas in ondp. Inoh nore oxporionse and arportuontation in the coloction, tralning, and ouporvitulon of ocumedore are noded for the ombodingnt of the coolal ldonl in the oum mothod and program. Anoordins to the "Interim Progross Repert of the Program of Studies and Researoh" of the smrlean Canglng Aseosietion,

Organised ouplng in Anorien is cenfronted with a orisie in parcomel. semrees of avilable leaderhip are dirling up. Larg mubers of ocuneslors whe have boen evaliable during these latter dopeeston yeare are belins abeorbed by normal businens operatlons. How sourees of leaderchlp matt be found. more adoguate roorulting wothode dorlsod, and wash

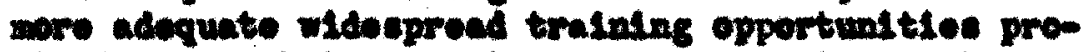

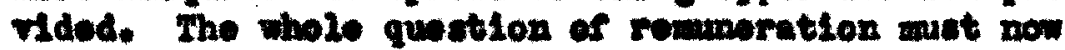

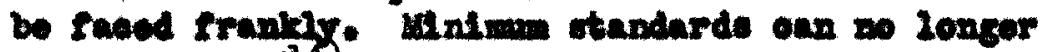
bostpored. 14 )

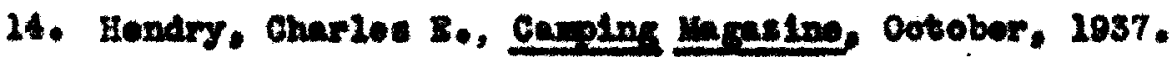


DIRECTOR

The oanp ilreotor ahould be the aybol of untty of the antire group. Maturally the eplrit of the oamp as ahole and the benorit oamper individually derive from the oamp experienoe, w111 dopend to a large extent on the dirootor and the type of program he or she derelops. In order affoctiroly to stimulate and gutde the group's behnilor, a good leader mate bo consolous of the wlathe and purposes of tho croug mabore. The good group loador dofines, stimiates, and erystallises the dosires of the group. and usually ohares with the coup in the effort to real1ze these purposes. The direotor who knows oaxplag from aotual expertonoe as a camper w111 often have a botter underetanding of the Indivduals with whom he works. Thus the camp dirootor atands out as a guide not only to the rest of the stafr. but for the camp as a whole.

Varloue ege 1inlts have been fired for oamp dirootors, but wost authorit1es agree that twonty-11\% years of age is the minimm. The Dational Park Sorvioe and the OIrl soouts of Amprian agree that the direotor mast be a persen of mature judgent, who w111 tale the full respensibility for the admintstration and progran of the oamp. Authoritles have mintalned that the edueational requiremente for a oup dirootor are Bachelor' Degree from an cooredited oollege, with a mor in ednotion or the soolal colonoes, and apeolalised training in reereational mothods and rarious oamping aotidities. Op to date, emphoris has been placed mainly upon traluing in odueation 
as the ohlef roquirenont for onmp directore. Howover, a reoent trond 1. towerd training in group and sooial work as offered in sohools of profesetond sosial work.

It 1. In the fiold of opoesal training for the job that wo mar directors fall below ctandarde. Befletonoy will be inoreaced if the direoter has taken a ond direotore' course, proforably within the last three years. Onily a fow of the oamp direetors in the Louleville area have obtainod any epoelal trainlug by taklug spoelal courses or by attending aamp infot tuter.

A good earp director also possenses ablilty as en exeoutive in 2eaderablp of counsolors and oampere. It is best if ho has had somo provioue experiene in an exoutive eapaoity. "The samp direotor should have at least two yoars swoeesaful oamplas oxperienoe in a woll organIned and woll conduoted cang. He should bo ongaged for at loast one wonth longer than the aetual eang seacon." 15)

The dirootor of Corered Bridge Roservation is alweye one of the professional excoutive in the Loulerille Counoll of Boy Soouts. The direotor for 1938 has a Babholor of Arts Degroe from unhlenbere In Allontown, Ponnyl Iranle. Ho has talen a four wonths oourse at Hownt Ary thoologleal Sentary in Philadolphie. Fe left there in Junuary of 1086 to attend the forty-third Fat loval Iraining sohool for soout oxeout1ves at Sohlef boy soent Reservation at Londhan, Iow Joreey. After a one month oourse there, he graduated and beesm

15. ChIldren's Wolfare Fodoration, "Toutative standards for Vacation Homos and carpe," 1982. 
Soout exeoutiv for a yoar at Black Dinnond Area Counoll, shanahla,

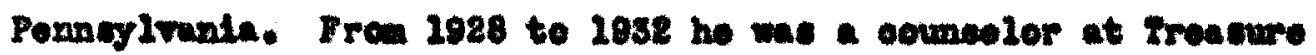
Islend Boge' Canp at Phlledelphia and alwo at Coneral Irenior Cunp. - Doy Soout oup at Allontein. Ponniglvanle. In 1956 ho wat trane-

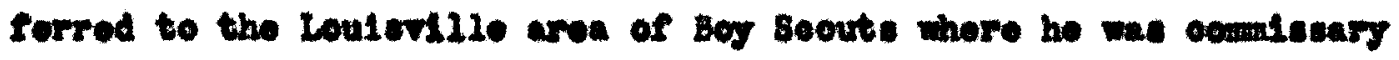
Alrepter in 2087, and oamp dirootor in 1038.

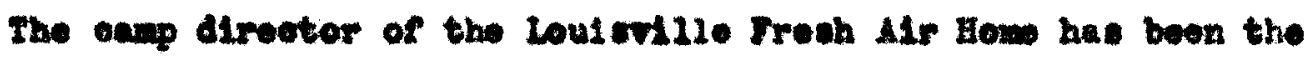
director for three yoare and is a tescber of physleal ducation in the

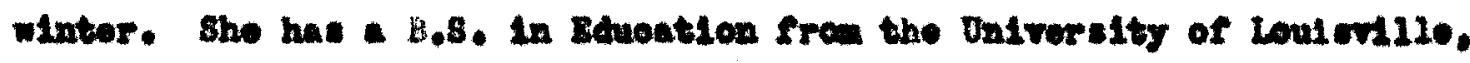

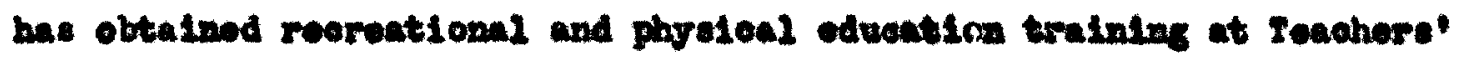

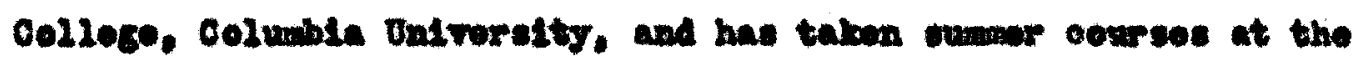
Undroratty of WLacheln und Poabody Colloge.

The Arcotor of Cang shantituok has an A,B, fyom Colorade with

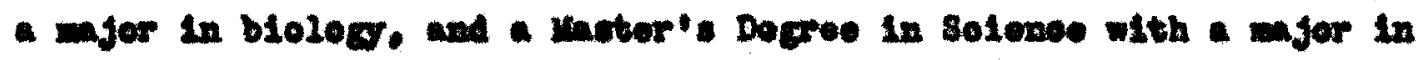

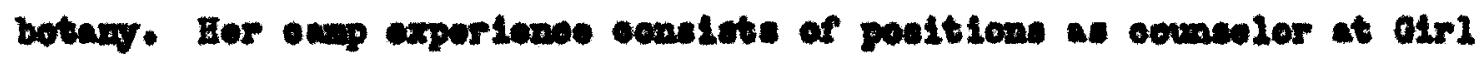

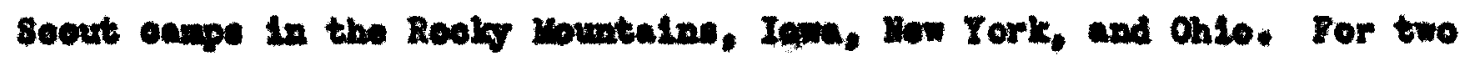

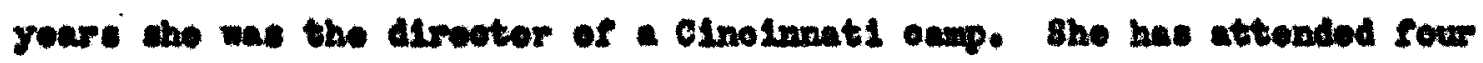

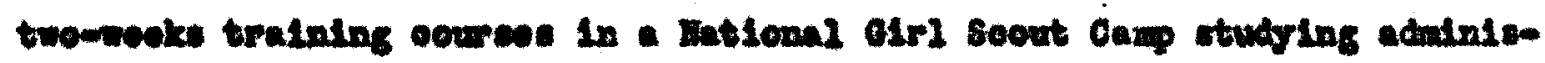

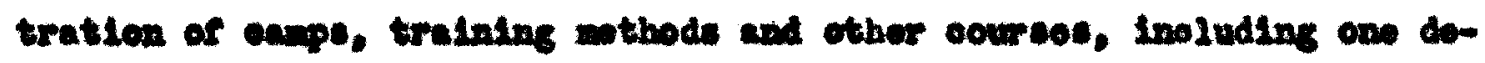

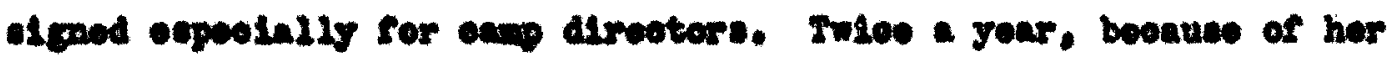

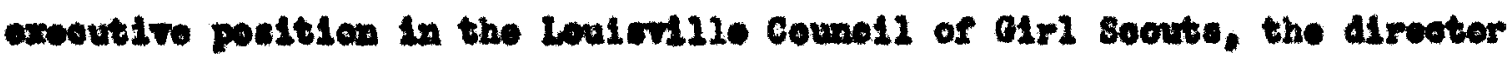
attende roglemal tralning oenree for soout loadort.

The excoutsve direotor of Das Band has been an oncoutive in the

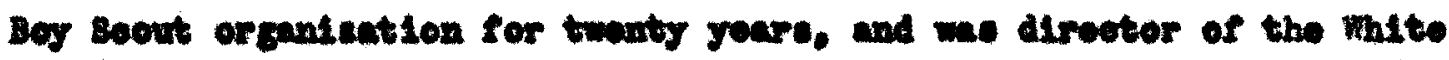
Dirielen in 2020. Ie Le now amentiw atreotor of the Colored Diviston, 
whloh ho organdsed in Loulorille in 1920. He also otarted the oamp for colored Boy Boouts, one of the firat of Its lind in the country. The progran direotor is a graduate of the Oniverelty of Indiara, has beon a coout for a number of years, and has been with the Louloville divieion for of ght yoars.

The direotor of Camp Corden has worked with the organisation of IIng'. Daughters and Sons sinos 2925. She is now the director of the youra people's work of the IIng's Daughters of the state of Kontuoky. Aslde from traloing rocelrod in thls organisation, the has had three

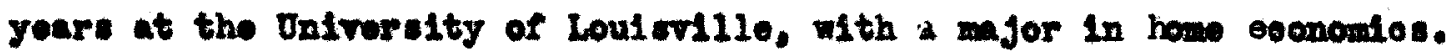

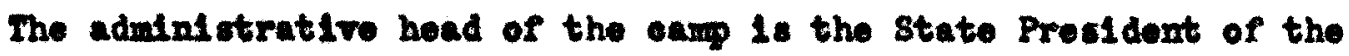
Xing's Daughtors and Sons of Eontuoky.

The direotor of the Camp for Colored Clris founded thls oump in 1921. She has had two and ono-half yoars of work at the Imiolpal College for Negroes, with a mor in soolology. Hor exporience conelate of soventeen yours with Pandly Sorrioe Organisation, during ton of whloh the did sonlor oace work. Sho has attonded lnotitutes and courees for soelal work in Loulorille, and now has a position as an H.Y.A. aupervieor.

Tho oamp direotor of Morry Ladges is ueually the girls' worker at Foslog Commity House. Th1s worker 18 roquired to be at least twenty-three yoars of age, to be a trainod coolal worker, and to have had som exupling exporienee. 


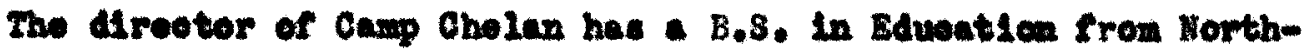
wort Wlesourl state Ieachor's College, wth a mor in phycleal odwatlom and a mor in acololew. She obtulnod additional orodits from

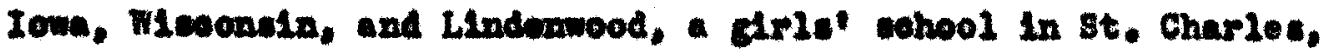

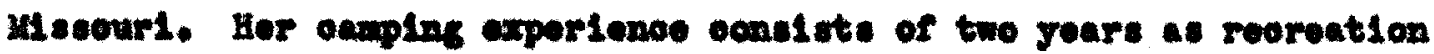

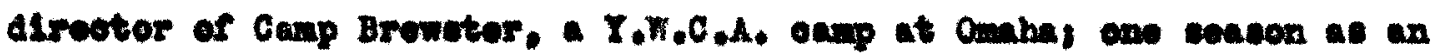

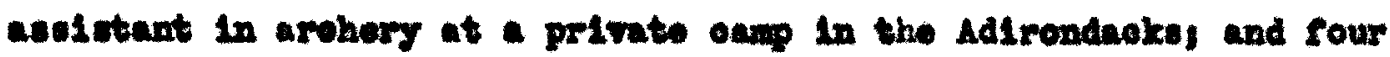

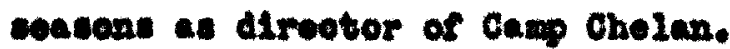

The directer of Ohlo Pleatinge has been with the X.H.C.A. for

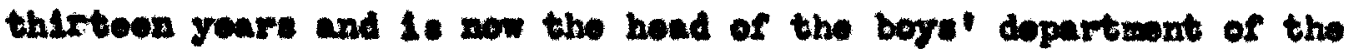
200al Y.M.C.A. He is a graduate of thryille College in Tomoseve. and has talon gradute work in soololog and porohology at the Onitrer-

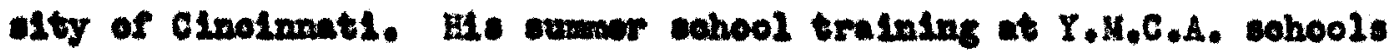
consl ste of courses in group work and eamplng. Bo has attended state and nutional oamp ventorvoes regularly. Als oamplng exportenoe oon-

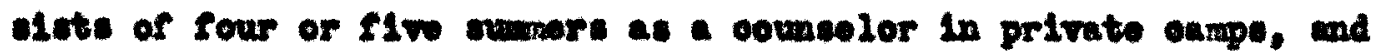

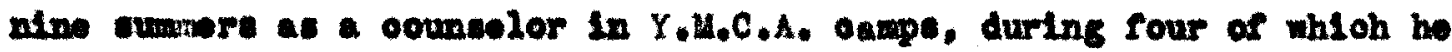
corred a progran direotor and oamp Arector. An the seacon of 1938 was exporinontal. the Alrootor of tho rellgloue procran, the athletio

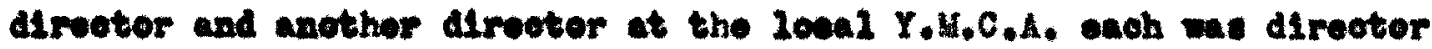

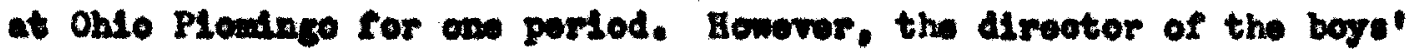
norl. whoce edvention and axpertenseare fren above. Is to bo the pormanont dirwator of the oung. 
The Bourd of Jennle Canaldy Rent Cottage weloote the matron or eupervisor. who is in oharge of the how durlng the sumer. Aooording to the prestdont of the Board, "tho utron muet bo a good Ghriotian

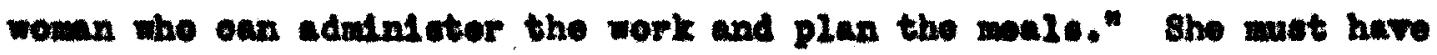
a nloe appoaranee and know how to noot poople. Hoed for work is a doternining Iactor in the eqleotion of this poreon.

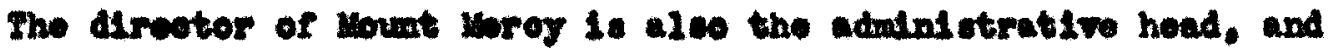

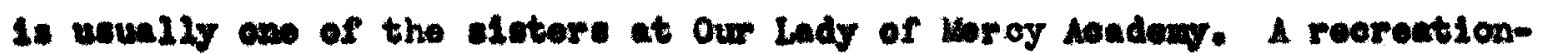
al alreotor was omploged in 1988 as an experlwont. Sho has taught

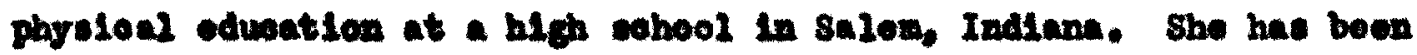

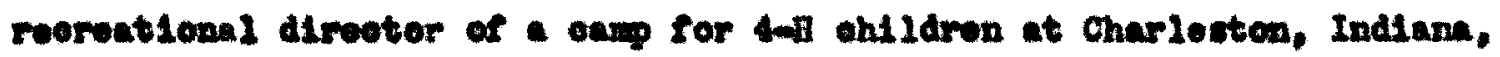
and toaohes rearoution, Aranties, Bngliah, and reading in the winter.

\section{COUUBELORS}

In this seotion, qualletentions disenesed will be related minly to thoce eouncelere wo ather 21 w wh the onmpere or are directIV reoponatble for the welfare of a cortaln nuber of eampers. Carper-coumedor potse

The number of ocwenselore noeded in relation to the number of oumpere variec conoldorably. but a staff ourflolont to usare the good

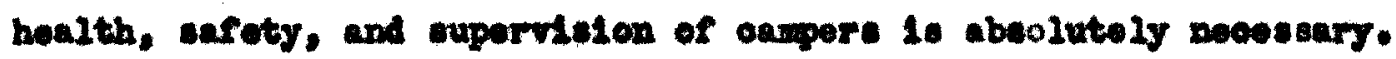
Ropomandations from difforent acuroes agsent os oomedor to ix oumpere an absolute antman for ontldren under nine yoar: (one to three or four is peforable). Ono counselor to olght or ten oldor oumpere is noveosary. The Hatlonnl Park Servioe cote a mintmun of one 
adult oomedor to overy olght eampor: In ohildrenet eampe. The Boston Counoll of Soolal Agenoles sete the minlman still hichor. caylng that the proportion of ohdlaren to centor oouncelors, exelusive of the dirsetor, nuree, doetor, ocok, and all non-profosstomal omployece ahould not be wore than fire ohildren to one senior counselor. The eumpormoounselor ratio is important, beoause if the counselor hat too mayy ohlldren for whos he 18 reapenalble, he w112 often be so exhausted, after day of aetivities and instruotion, that he w11 negleot what should be the wost lmportant part of his responelbillty: that of studying the ohild's noeds and dorelopment. Ohlo Ploxingo has one counsolor to olght oumpera. At shantitaok one oounuelor 18 responelble for orery three glrls. A counselor for every nine girle, and owe for erery elght boys. Is the ratio at the

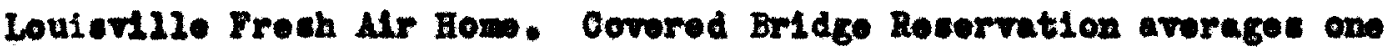

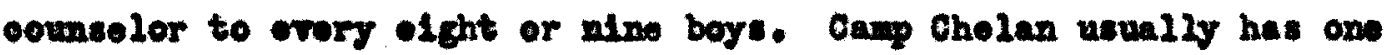
oounselor to orry olght girle. At Herry Lodges four staff mobers in addition to relunteer pounedors (uavally three or four to twentycour oapere) makes an average of about elx girls to a senior councelor. The Camp for Colored Girle everages nine girle to gouncelor. At Camp Cordon, three otacf mombere serve the thirty-one oumpers. Dan Beard has one councolor to orery elght or atno boys. At the Volunteors' Camp the direotor and her husband, assioted by a minteter and his wife, have ohnrge of the twonty-five oumpers. 


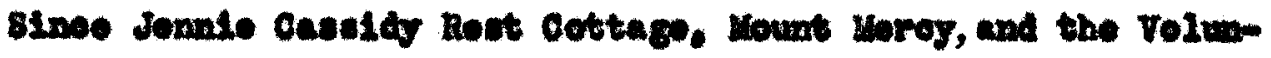

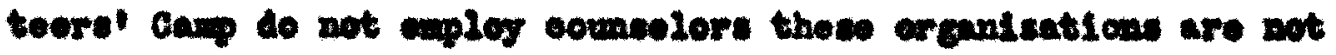
included in the fellentrs dicounton on osmenzors.

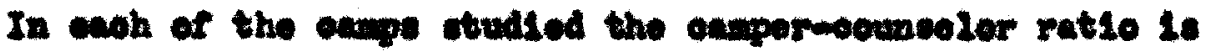

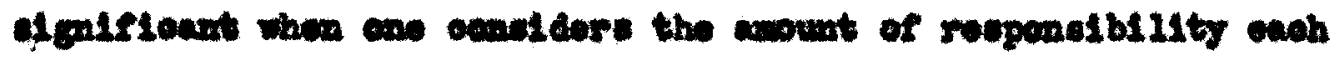

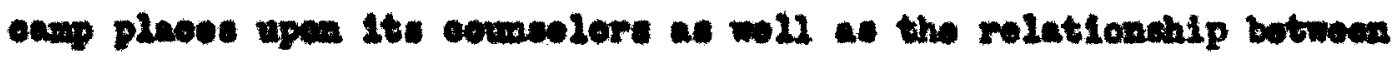
exiger and scunelor.

12

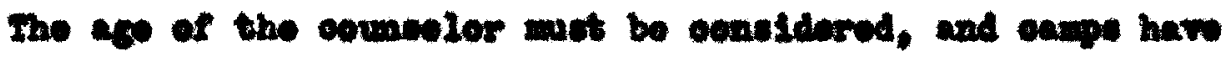
aften falled to realle the imparteme of this in rogurd to louderm ship. It It conorally acreed that the mafor covavelore bhould be

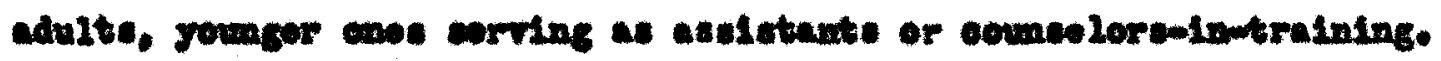

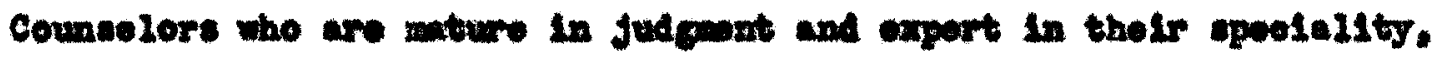

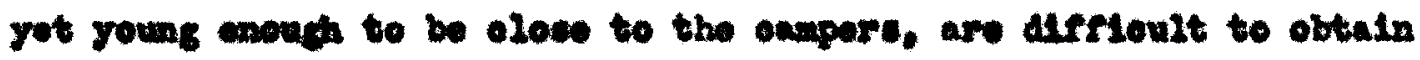

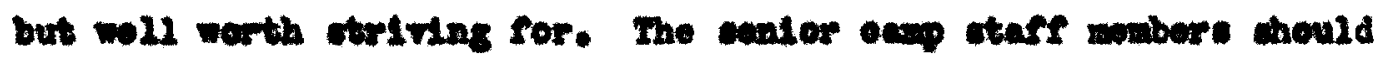

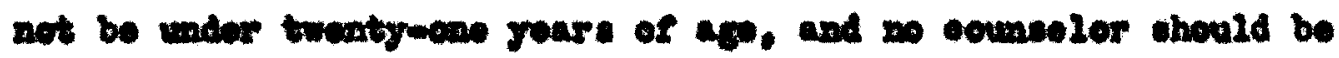
undor elghtean.

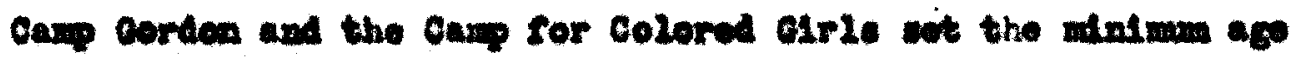

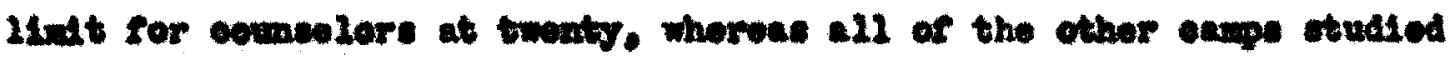

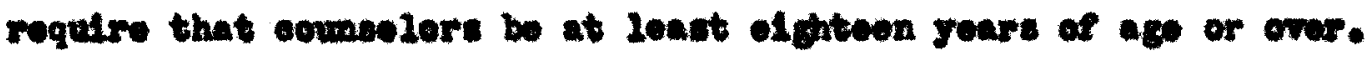

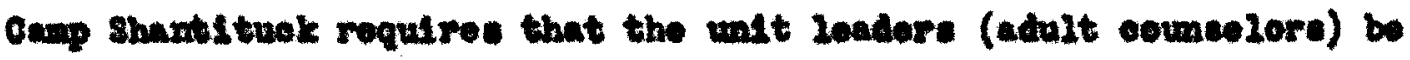

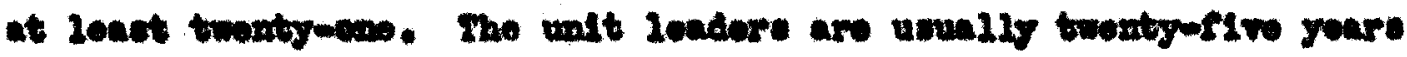

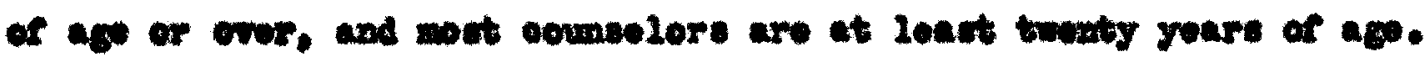

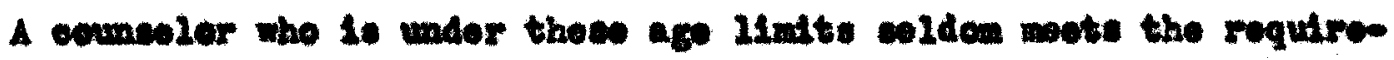

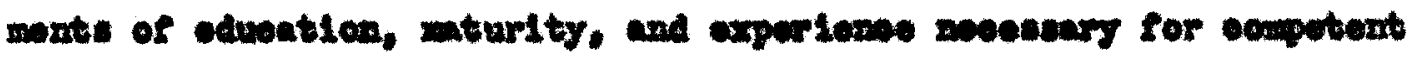




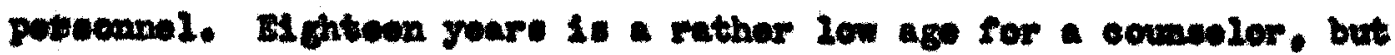
If a balanes of youngor and older stafe nombers an be attalnod, the

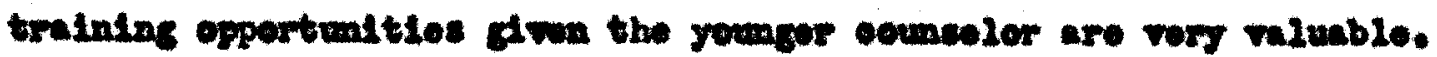
Bduention and Experionee.

A beckground of edvoution and wpertemes, whloh propares

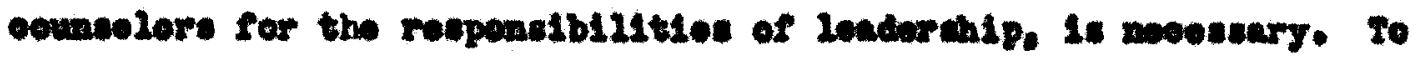

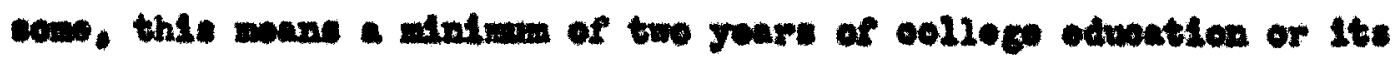

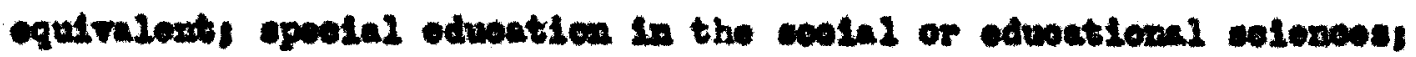
Ieaderahlp exporlonos with ohlldron in reorentlonal or informal

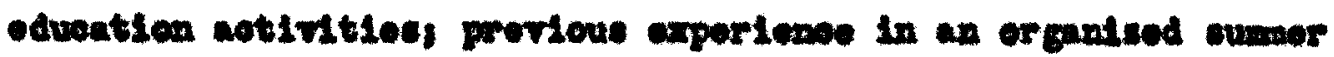

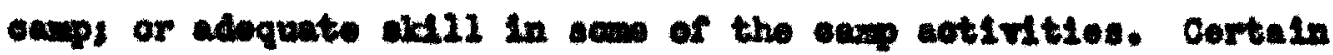
othore requitro number of yoars of onmplng exporionos, and training In the methode and prograx of oamplng by attendanes at ono or wore cang tralning oowrwes.

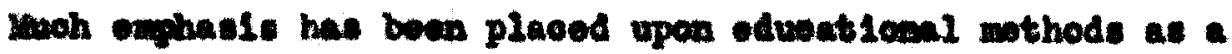

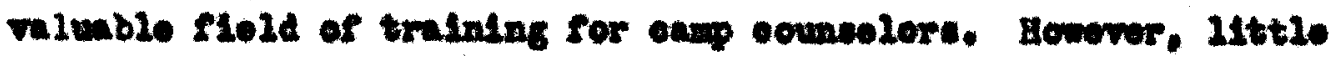

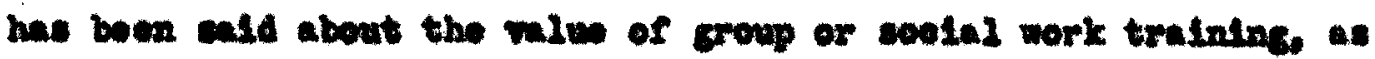

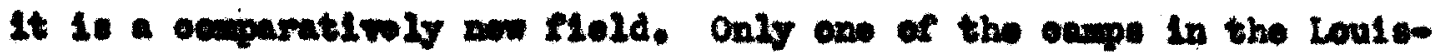

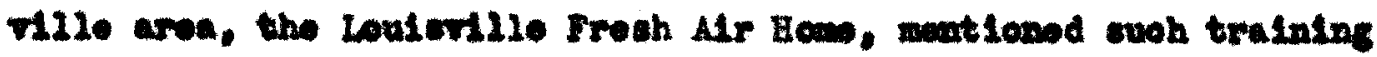
as a roguinesont for ocveselors. Porhape thil type of tralning 18 were viluble in holpleg to carry out the purposes for whtoh mav oups are orgundzed, than any othor trpe of tralning prorlously rogutrod. 
The in noed of a oomeeler, the ablilty to work with the group as a part of the group, is gained through group work train1ng. In oste work training, on learne how to work with individuals and to help then beowe adjucted to nen sttuations (for what oumper

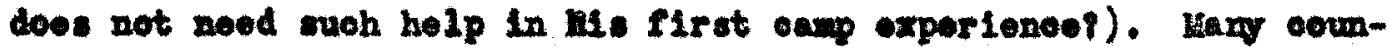
selore have not had experlense worklng as eroup loadons bofore oom: Ing to sanp, and mary of those who have suph experlenee fall to understand the group prosess, partially bocause of a lack of group work training. Ofton moh bottor prograx is aariled out whon this noed 18 211led. Although thore is no odwoational agonoy whioh prom pares wn primarliy for canp leadormip as a profesalon, there are organisations whioh prepare atudente for the type of leadorship eamp requires. At the Dulversity of Loulovillo may of the soolal work ocures are deslgaed to propare the otudent for croup or ganisation and leaderohlp.

Hany of the edventional standards diseused above apply for oamp

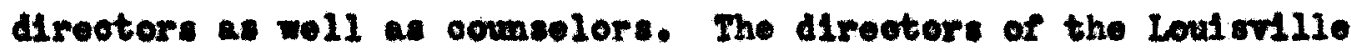
ondps laok corteln of thes quallfiention partially beouse the organisations exploging thom do not reallse the laportanoe of oush braining. Eonoe they do not give the direotors the tiwo or remeneration whloh would wake it possiblo for thea to attend institutes and tralning courees.

The camps which use viunteers in place of pald councelors mats put woh exphasts on premoamp training in ordor to comply with tho epirit of some standards. 
The dirveter of the canp for colored Arle attempte to got

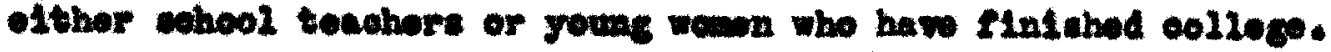

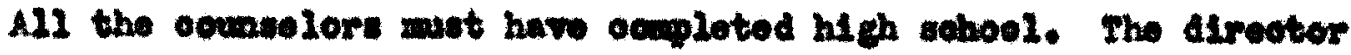
treter that It is arrioult to obtain woll qualifled porsons who w131 do pluntear work.

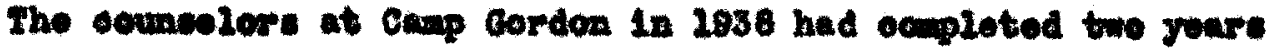
of oollege, but at thit ang whe now exportwont no standards had

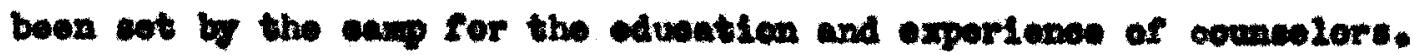

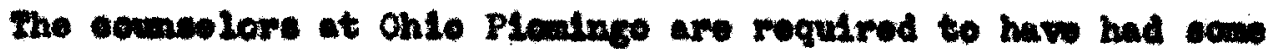

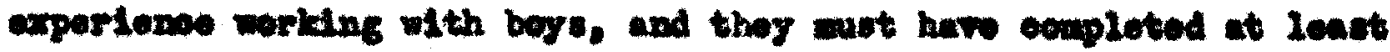

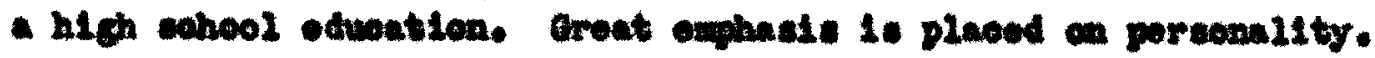
The troop leadore at Shantluek haw hed exportono with giris during

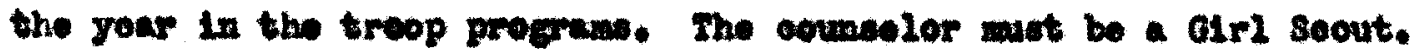
In the "Roport of the roosmondatlons of the Onmp study" ocoducted

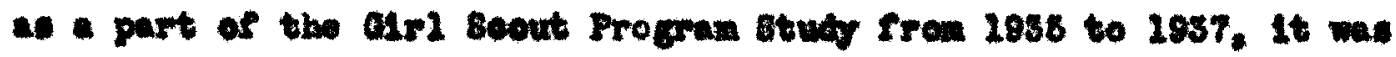

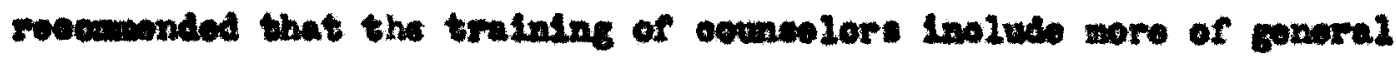

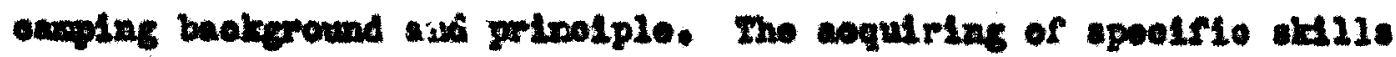

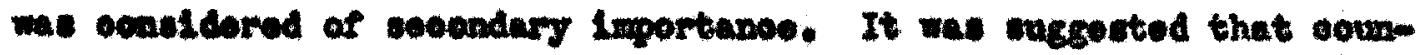

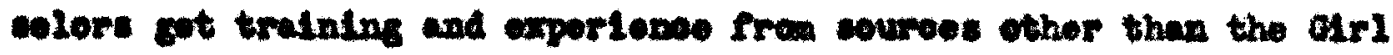
soout Organdention.

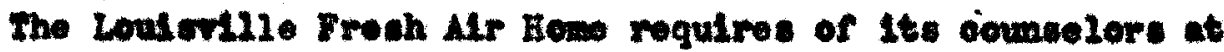

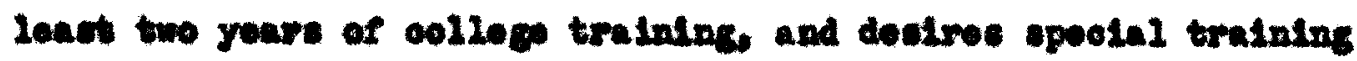

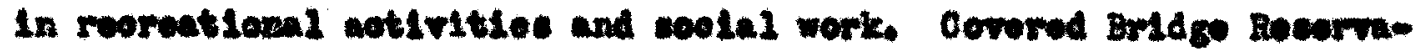
then requires that the won ohocen for activity leaders be axpertse

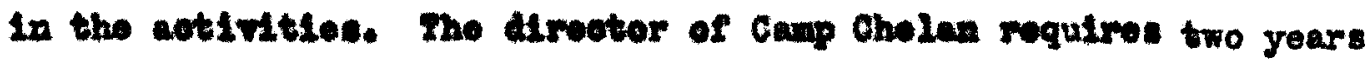


of colleg tralning for a tull comelorchip, wh we or two ex-

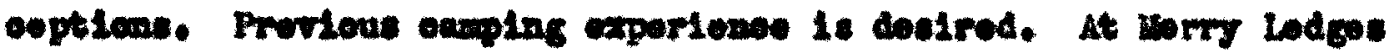
- oollege cavedien is proforred but not roqutred of councolore. Councelore have unally galnod expertones by worl with croppe is

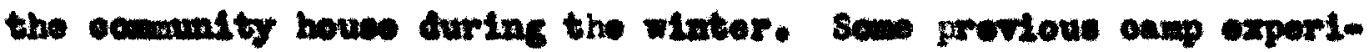

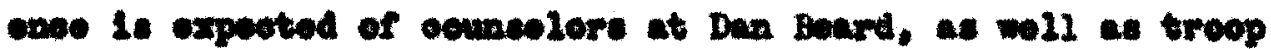

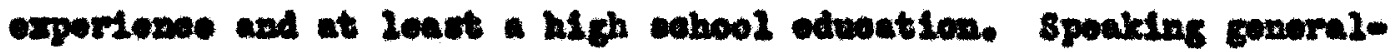

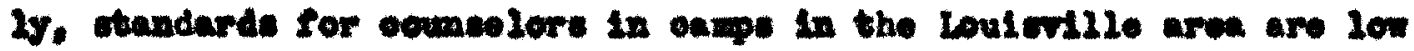

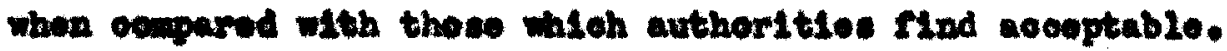
Poroenn 11tr Pactore

Porcomallty footore are importunt in the alootion of porsomel In cumar ourpe. In this oomeotien nontal hrclone hes teught us to

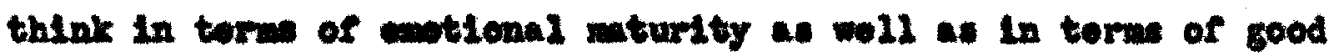
ohareoter and housty. A Inoero Intorect in the oumpers is perhape the flret and forvast eceontlal of a cueoocutul couneolor. Stablilty and roliablity are aloo inportant tratte. .

An Intrenesting thd 16) mode of the ohurneteristios whioh

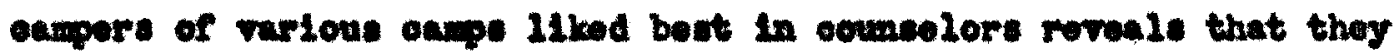
faver commendore who aret

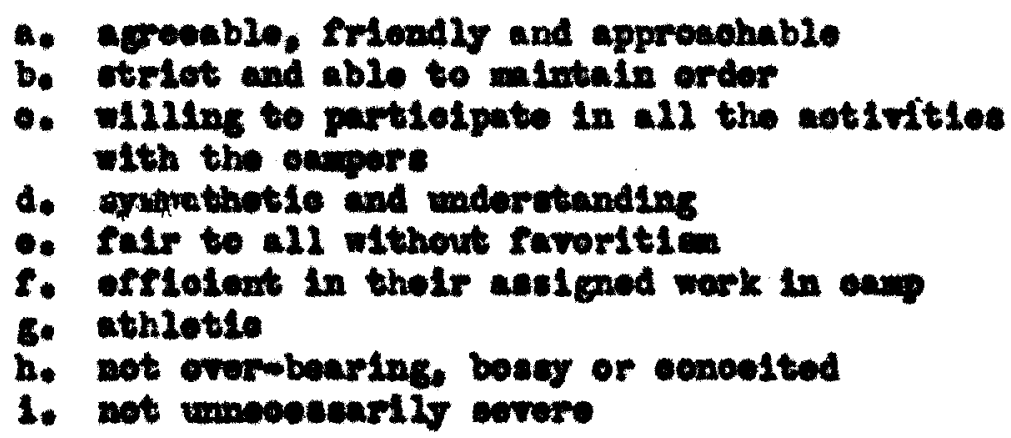

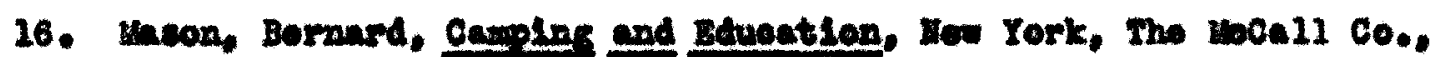
1080, p. 114 . 


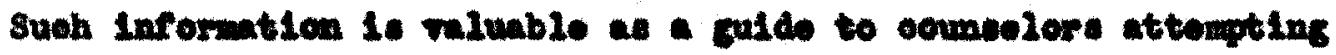
to wect the noeds of anpors.

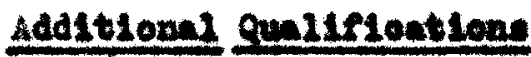

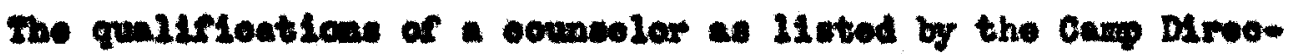

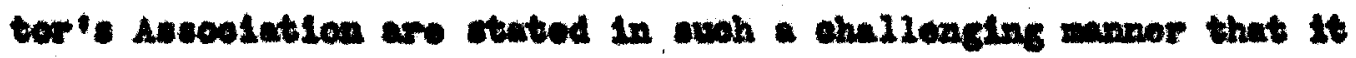

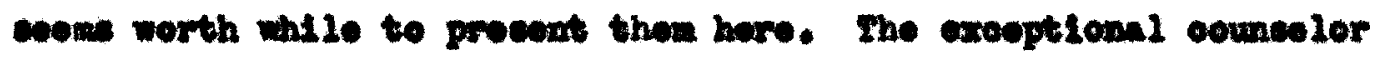
posersces

1. Cood, radlant hoalth and well-belng that rocult frow a wil balunoed day of work. pley, reat. and wleo atrention to rood.

2. In mbouded and untirting Interest in cirls and boys whoh dwe soct to each dy and beope the hant roons.

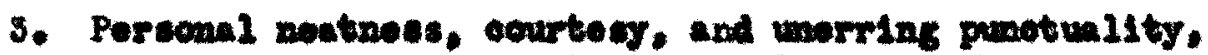

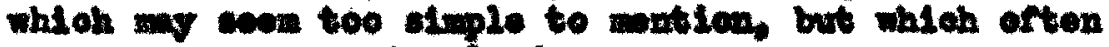
nals the sucoese of a leader.

4. A jogtuinese in simple daliy taske and a been conve of humor.

B. A lowe of growlng thinge and feeling of "hominose" In the wdint of woods and sielde.

6. Orlglnulity and Inltiative whloh always oulivon work with youns people.

7. AbL115 to mande wicely the reaponelbility that is

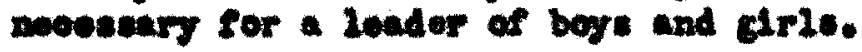

8. Binoertty in thought and cotion, and a trustworthines

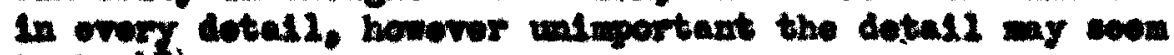
te. (17)

As no on opuncelor wll poisese all of these quallflontions, thoy

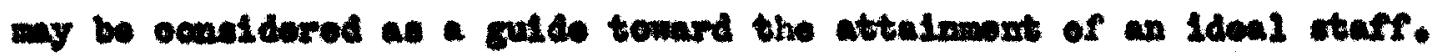

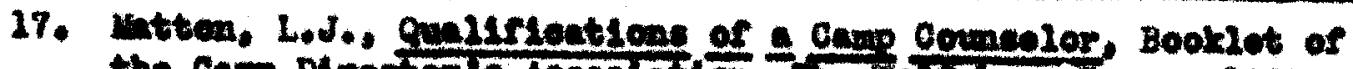

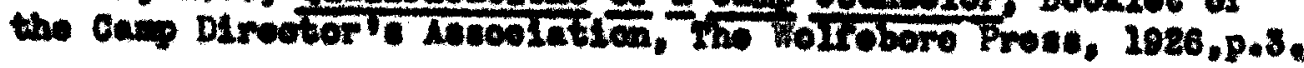


The anjority of the otaff at Dan Board have elther boen former oampors or leadere of boys during the winter, so they have had oow experienoe with boys. Furthor qualifieatiene for the oounselors of Lerry Lodge aro that the oomselore have good oharacter and ablilty to ooutrol a group. They are ohosen wocording to allis, ab111t1es and adaptab111ty. An attompt to loam the leadoronip abilities end allis of applloante for poultions as ooumelors at Camp Chelan is mado by a ohook 11 st used as a part of the applioat1on blank. A ocmselor's rweomandation blank, also usod, I: a good way of gaining an objeotive inelght into the combelor's quallfleations. Porsanal, physloal, and montal qualltles, as noll an leadorinlp and adulnistrativo ablitty are lookod for in leadere at Corered Bridge Rearration. The caniniotrative direetor of the Loulerille Prech Alr How expreseed the need for tralnod, exporlonoed leadershlp for the proper developient of eampers. The lack of suoh

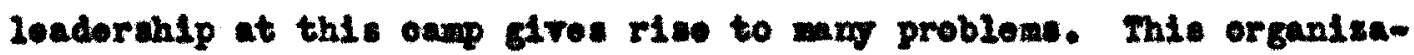
tLon is an oxamplo of one where trainod leaderanip is manted, but whloh eannot afford to pay the wajerity of the staff. There were I1w full the pald workers in 1938, and about twenty-rive volunteers. At shantituok, the qualifiontions of the unlt leader and hor assiotant are oloarly outlined. The goneral soope of her reaponelbility 18 otated as follows The unit leader is responsible to the cane director for the safety and happlness of a given number of cirls in anit. She is responesble for the interpretation of unit atandards and programe, and for adapting the program to the noede of the 


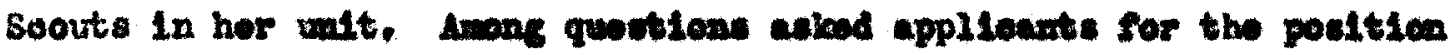

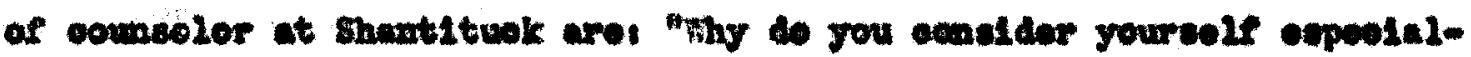
If genufled for the purtioular positien which you cooks why do you

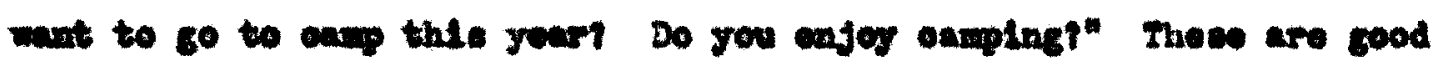

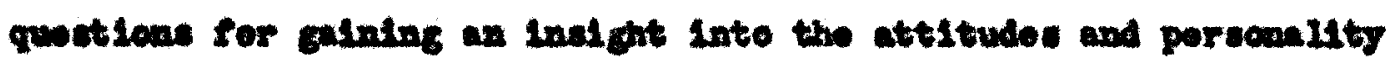
of the applieart. The alroctore of ohlo PLomingo atterpt to Ieara

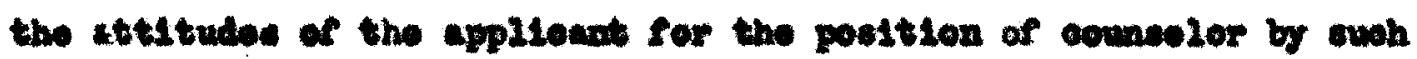

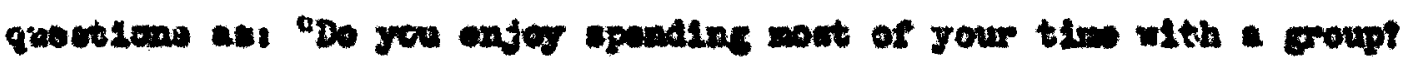
by roureales or with ono or two frlendet Are you intorouted in boge to play whit to towoht or 18 yow intorent rathor in the porfection

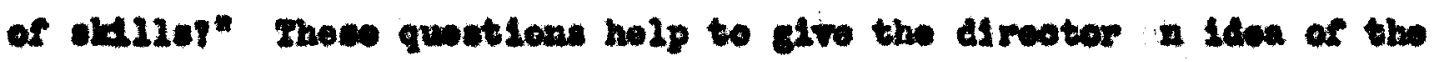
typo of pereon he it to work with.

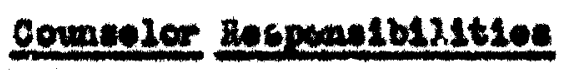

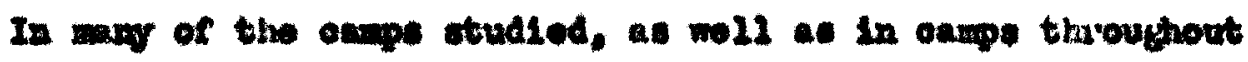

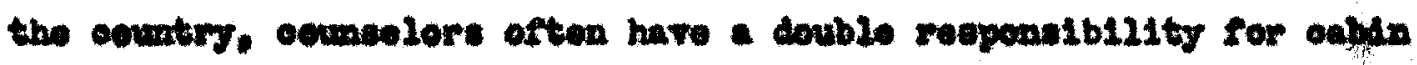

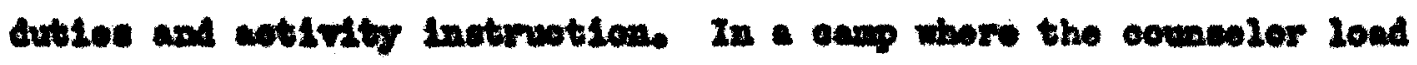
1. not teo howy. that 1s. were the proportion of councolore to

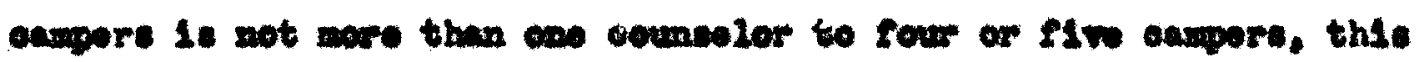

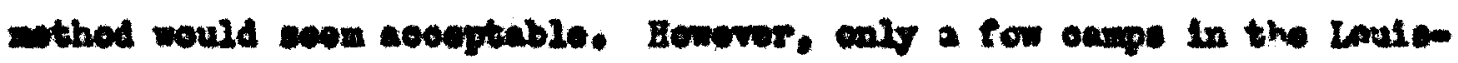

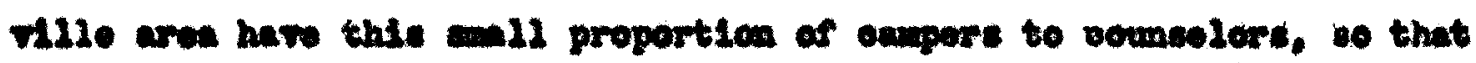

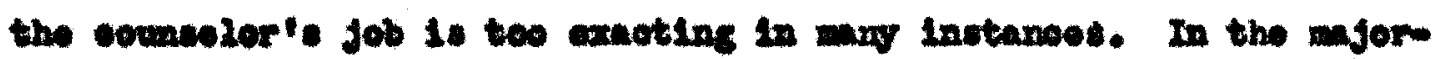

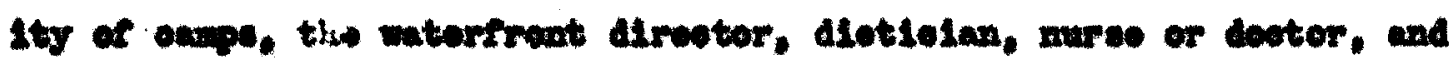

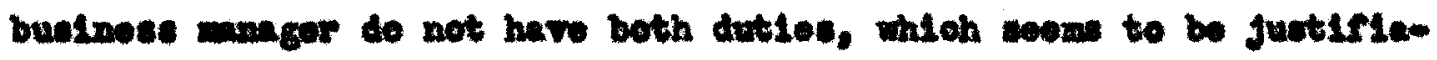
ble boouce they have a greater responetbility in tholr and dutios than the othor Inotruotere de. 
The pour leeder, as afforvatlated from the inotroetor, has

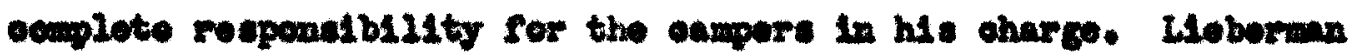

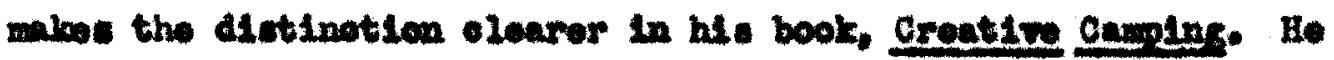

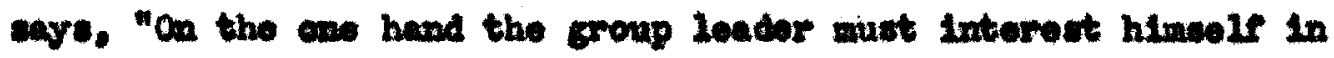

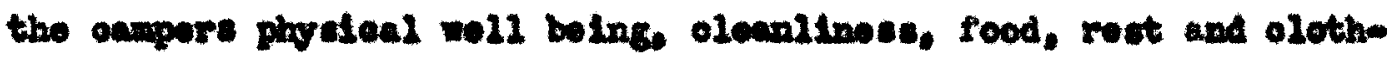

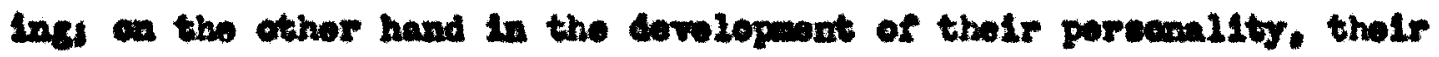

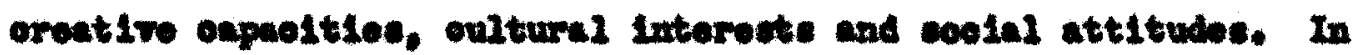

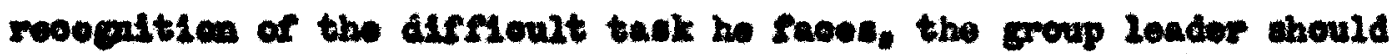

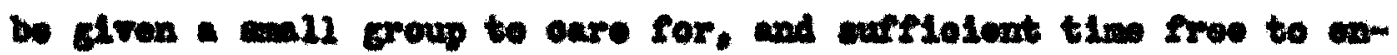
able hla te ave the group his undirided attentien whlle on duty." 18)

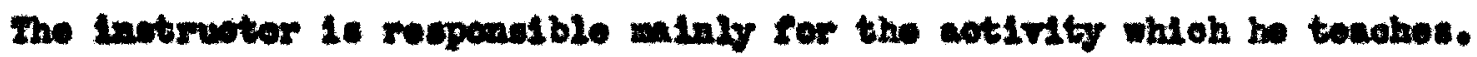

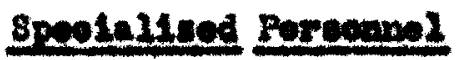

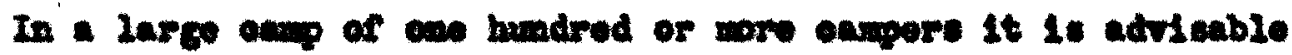
to have opeelal intomotore who have only dutlos of ectivity lantruct10n. provided too mah oxighets is not put upon the sotivity iteolf. rather that upen the crolognews of the sapper. If the councelor hat too man duties, he eanot parform lther thowe of inctruotion or those of

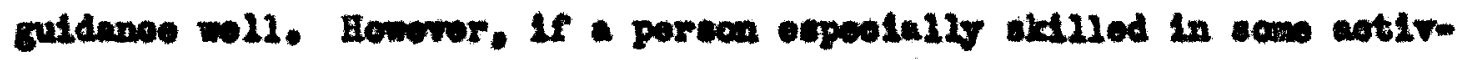

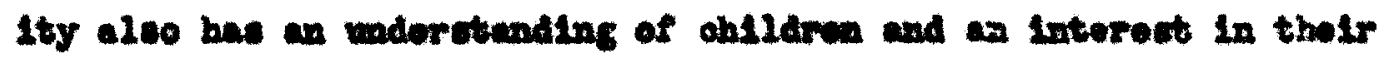
whole porecandty. this preon is profomble to wo wth extll only.

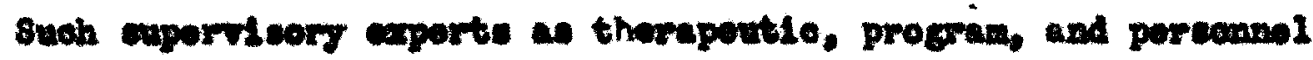
Alnectere ere very holpotul a adviser to the otafe. Por a ous that

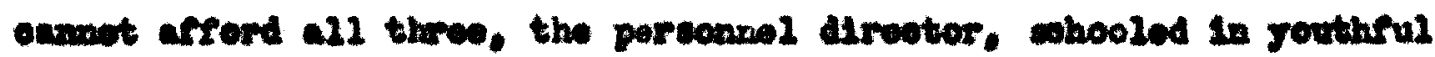

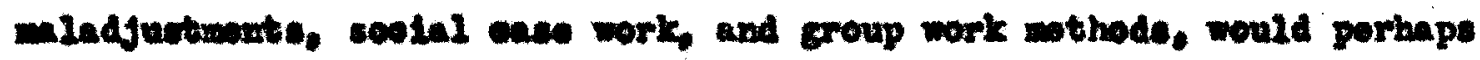

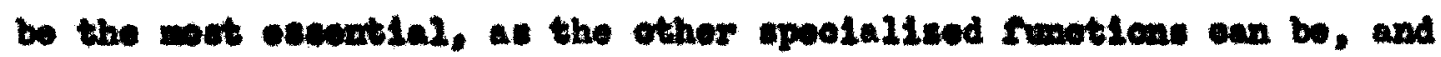

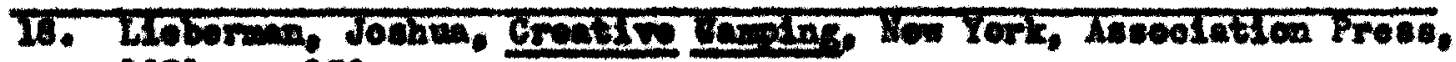
2082. p. 152 . 
very often are oarried out by other staff monbert. Ho woh porsons hare been anployed on the ataff of any of the oumpe in the Coulerille area.

It 1. very dectrable for the oasp to have ando Instruotor, that 19, som poroon with ouffioiont training to lowd singing and to

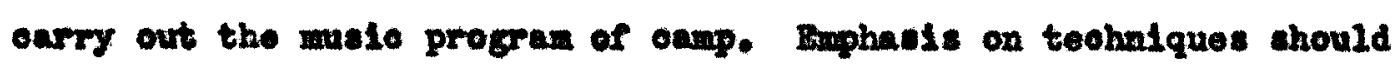
be secondary to onjogmont and appreolation of good mallio. A good orart instruotor $\mathbf{1 1 1}$ have abjilty to stimlate intereat in the aotir1ty as well as wall in a varlety of orarts. The nature lore inutruotor should have epeoial akill in stimalating inquiry and Imagination In addition to a conuine love of out-of-doors. Tho drasutio instruotor whould place a seocendary amphase on tochniques of produotion, and a primary exphais on the oreatironess and ralwe the indifldual oh1la is galning from the dramatio exporienos.

These speolal instruotors are ohosen for disoussion as they are coneidered raluable in a carm progran, llot all of the oupps in the Louisvillo aroe have an lestruotor for osoh one of these activities. Howerer, most of the aetivities are offored and are unually direoted by scase otaff mobor as a part of his dutios.

The councelore at Merry Lodges have reaponaibillties in aotirIty Instruotion in addition to rosponsibilities for the oumpors' developmont. The girle' workor and boys' worker, along with the rolunteor counsolor,, oarry out the aotivity progrom. At Dan Board, one of the staff mobers is direotor of reorention, oovering mont of the aotiritios orfored. A oamp Chaplain lo also on the staff to 


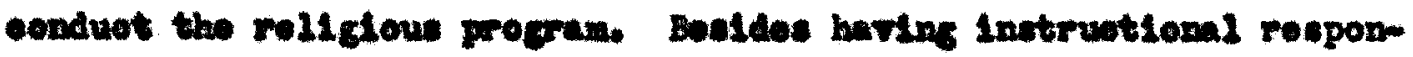

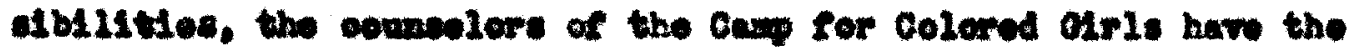

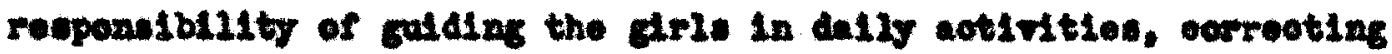

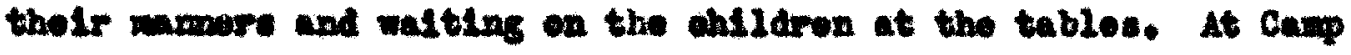
Cordon in 1080, the three otafe momber. Inoluding the alruotor. had obarge of the ootifitles and the oure of the ohildren an well. At Onto Ploninge. the dector dese not have obln dutles, but all of the other epunelers, inoluding the aterfreat diroetor, have exbla

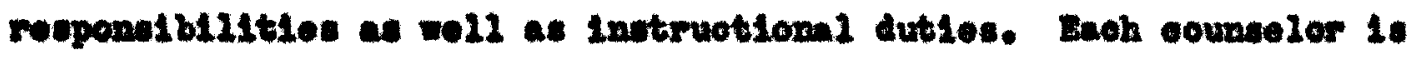
reoponidble for coren or elght boy to wee that thelr conduot is

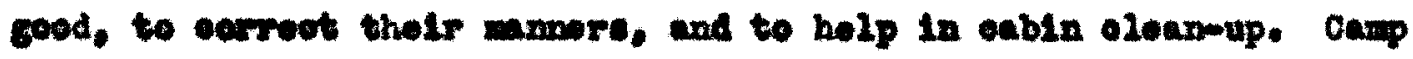

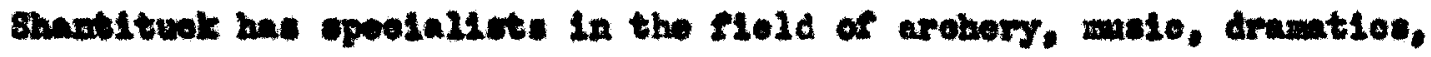

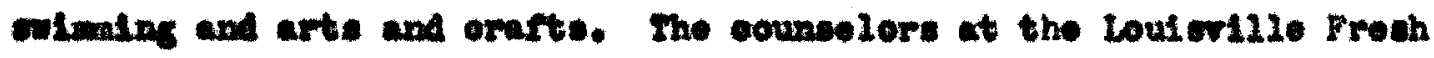

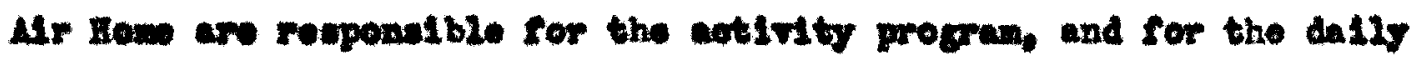
tratulus of the ohildren in manowe and eleanting of the dormiterios and shooke. The pormen in oharge of the nothore' and bablos' cottage 1s the plantet for the ontiro ourge and also direate the oleaning of the Anting roov for ach wal.

At Cowred Bridge Recervation, the doctor, mterfront ilrootor.

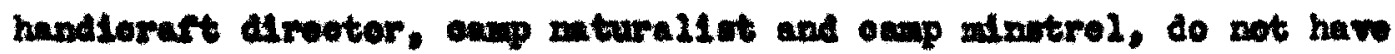

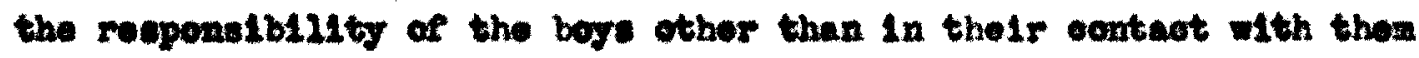
In ativity groups. The troop levdore, tho unually eom to oamp with the boy whea they load during the ninter, are rospenstble at onp for each of those boye. At Camp cholen, the progran alroetor.

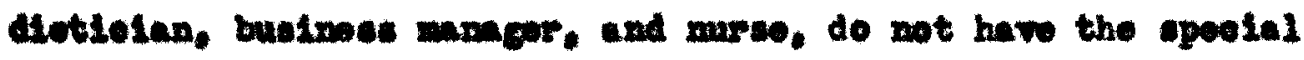

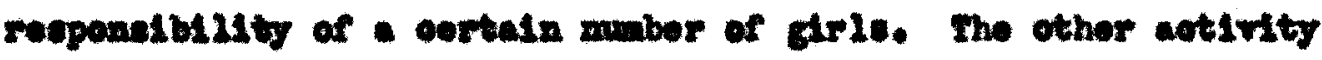

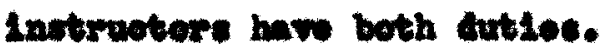


By this short aumary, wo on we the great dirersity in the sise of staff in the rarious campe and the emphasis plaeed upon the duties of the otafe members. Sinoe Jennie Caesidy Rost Cottage, Mount Horoy, and the Volunteers' Camp do not omploy oounelors, no Individual development is striven for in the osmpere. However, it would seom adviable If t leat a reoreational direstor, ${ }^{19}$ ) and atafe nomber were eaployed to otudy tho indiridual's neede or desires. Beveral yeara ago a reoreational direotor whe omployed by Jennie Cassidy Rest Cottage, but this did not prove satiefeotory at the tive. This may have been due to the Individual's laok of ablilty to five the ampers the type of program they wanted in the oholos of suoh pereon adequate quelifiontions should be not. Suoh plan oould be beginning in giving oampers who attend sonethling oometruetive, and a valuble exporienoe to earry with then after the racation period.

The oervioes of a epesiallet in montal hyglene and personality probleme is very helphul in helping to interpret behavior problew, and those of all campere, to the 10as experienoed oounators. None of the oampe in the Louteri110 area employ any aun person on the stafe. Soreral of tho camp direotors when acked about the troatmont of beharlor problens in oamp. said that if woh ohlidren oould not be made to behave by the direotor, they were sent home. We cannot expect to be bivIng the cort of tralning needed by these ohildren if auch a procodure is used. Many times these ohlldren are the onos whe need oamp experianoe the noet.

19. Hount Heroy employed a reoreational direotor in 1938. 


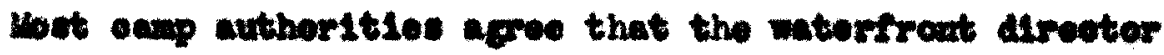

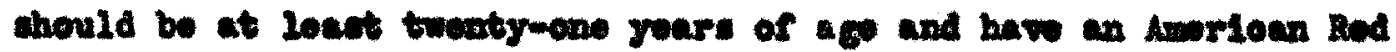

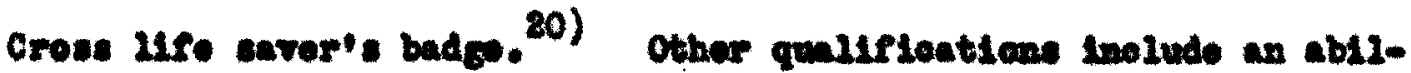
Ity to teach oulmalng and axporlenos in wotelns to a wterment.

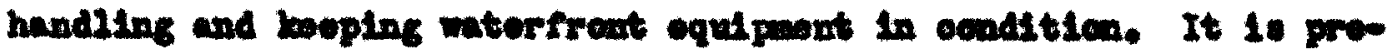

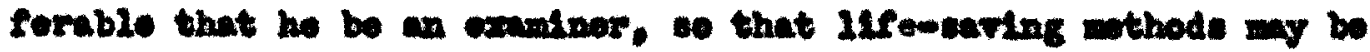
tangte.

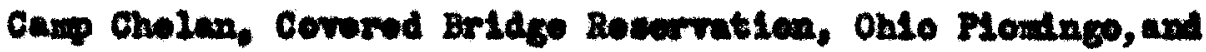

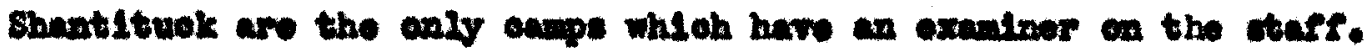

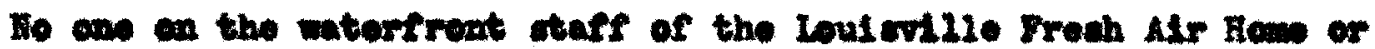

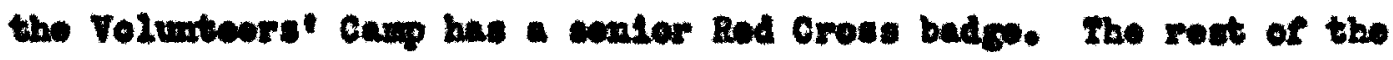

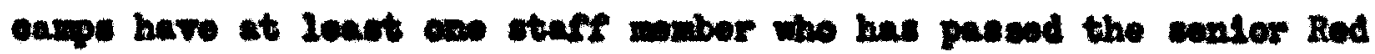

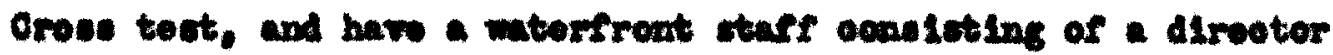

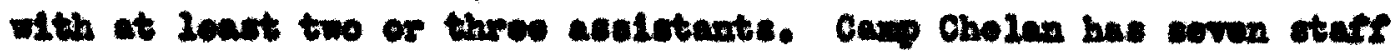
nombers on the waternow in addition to the diveoter. At the

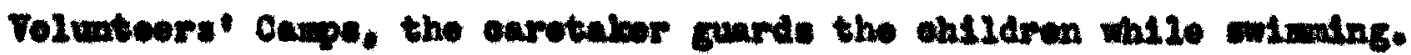

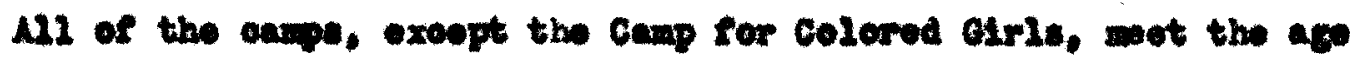

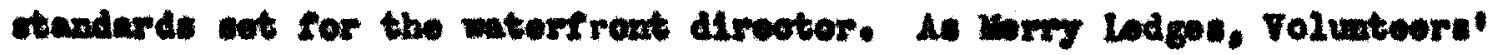

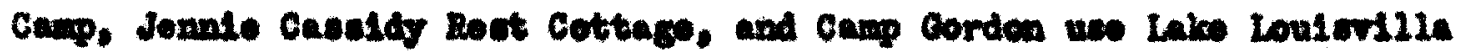

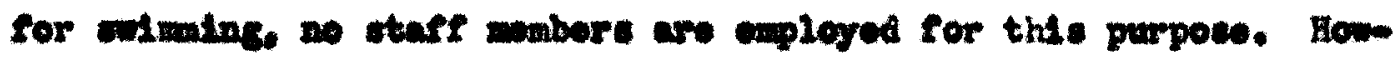
over. two mabere of the etafe a larry Lodge glve the oagpers

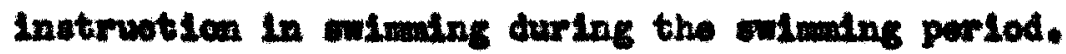

20. The Amorican Bod Crose menteren ege lindt is twooty. 
The modical staff of amp hould inolude a regiotered mareo or dootor. 21) If the number of cumpers exocede one knogred, it is ossential that edditlonal nolleal ar naralne ouro be provided. It is

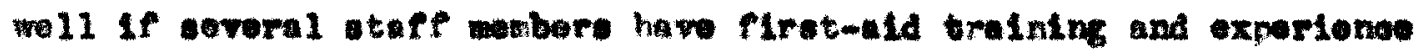

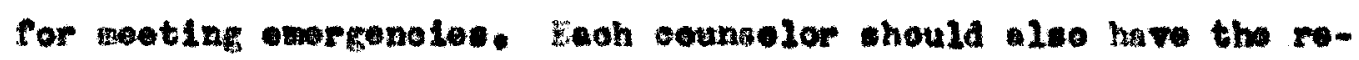
sponsiblilty for waintelining the helth of ach ohild in hor oabin Group or undt, to soo that she learno datly houlth hablts, and repor to the murse twloe wok far hoalth oheokmp, and at onoe in oase of injury or phyetenl roed.

It 16 deslrable to have coneone at eamp other than the direoter to aeslat in admintebration, or mangonont at the dirootor has so many other roponalbilitioe. 28) The Oleveland Gamp coundl eugreate that anp employ all-tiwe realdent seorotary whonover posalble

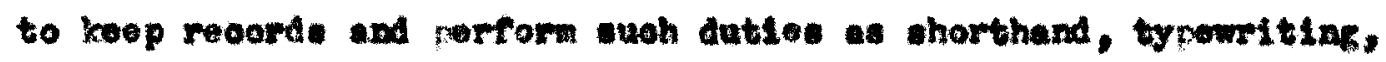
and bok-keopling. None of the oasge in the louleville ares have ouoh - peraon on the start, and few heve anafore. Onio flomingo eaployed a manger at osup in 1938, as an oxporteont, and found that this idea proved te bery satiafactory. elnes it left the onp director adequate tino to plan the progrm and ouporvise councelore.

21. Soni or madical tudente aro not poroved by omp authorities.

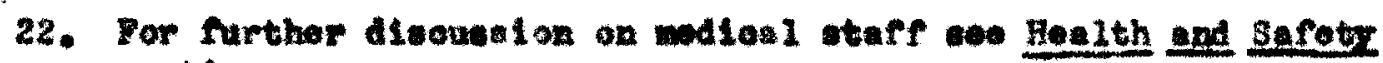
aection.

28. 300 Adalinietration veotion. 
Hany of the dircotere of the oxpe ctudted. not caly hum the

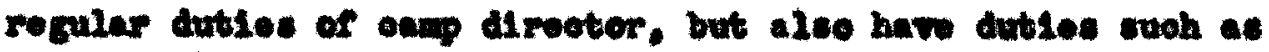

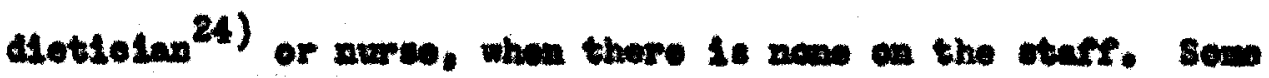
Afrotere owin holp on the matortront wan an adoquate otafe is

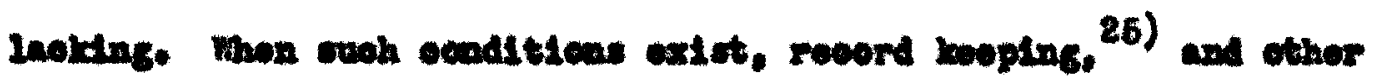

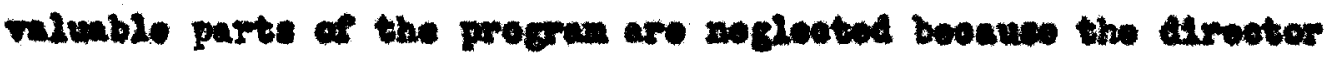

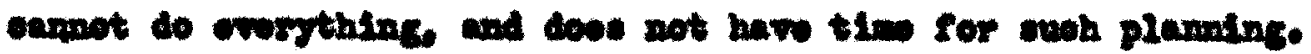

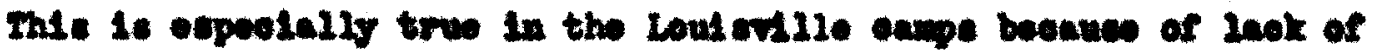

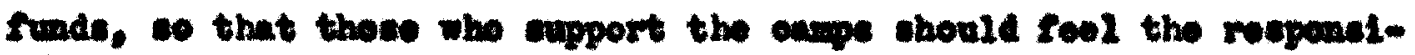

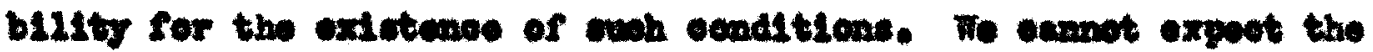

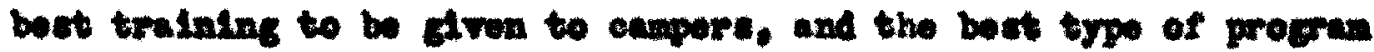

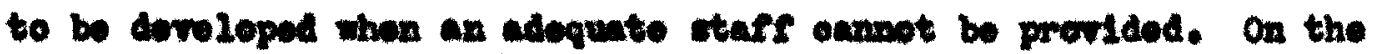

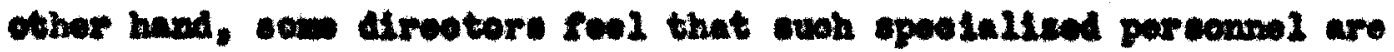

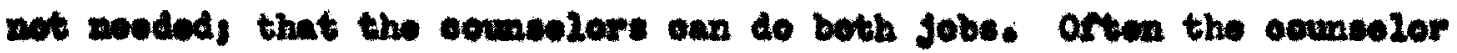

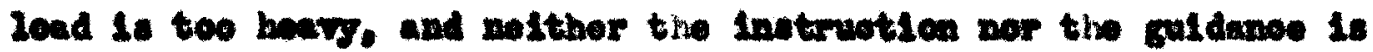

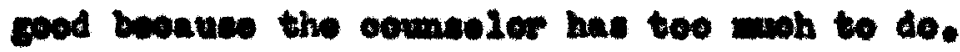
trand of stax seloction

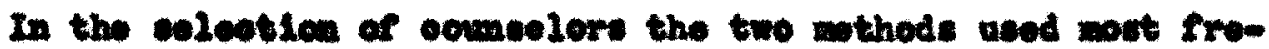

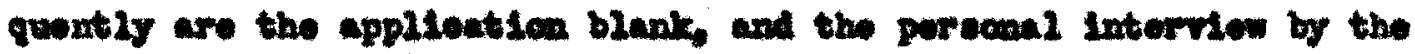

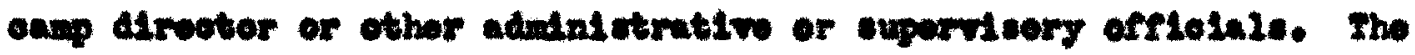

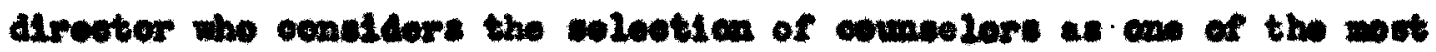

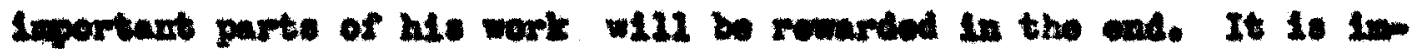

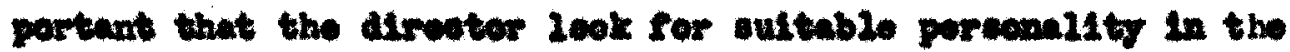

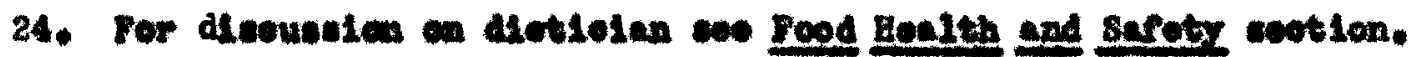

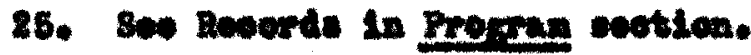




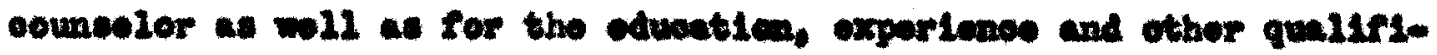

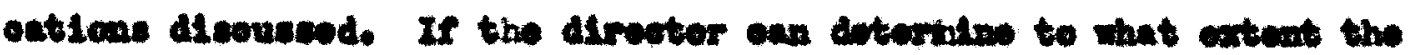

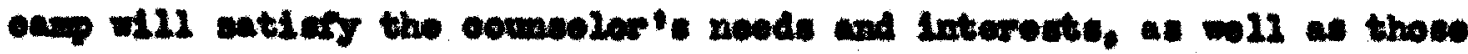

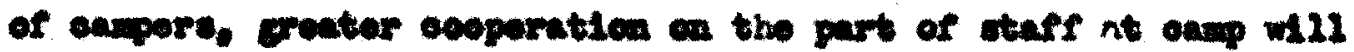

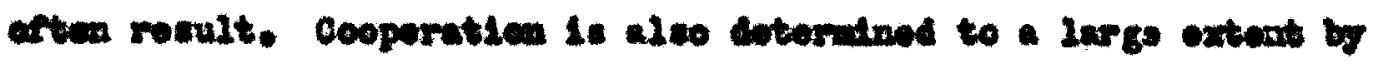
the eariy scataet the direoter has in eoleotinc his sturf.

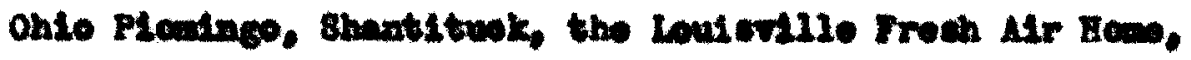

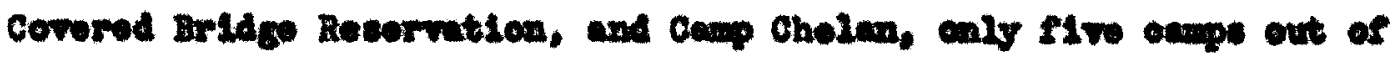
the twolve in the Louluvilis aron, have a miform appliontien blank

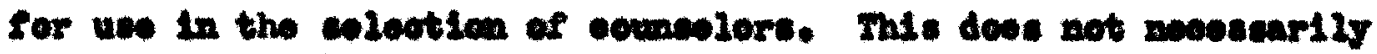
wan that the othor ompe do not put thought inte tholr eoleotlon of covavelort, but the applloatlon blank dwe one a oloar ldat of what 1s sought in 20aders, and caves the dibeotor a clear wane of comparing appliounts.

\section{Bemmerateg}

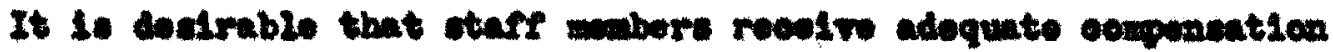

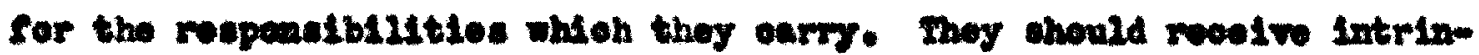

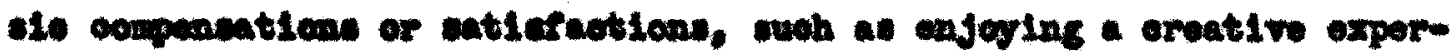

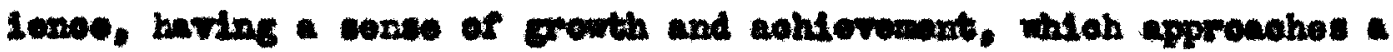

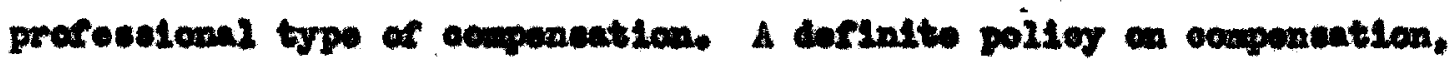

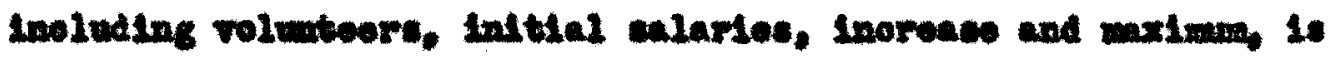

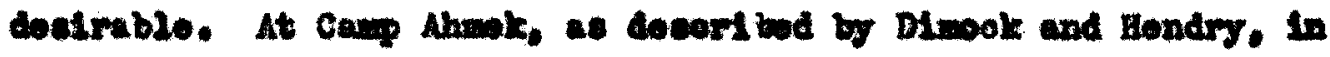

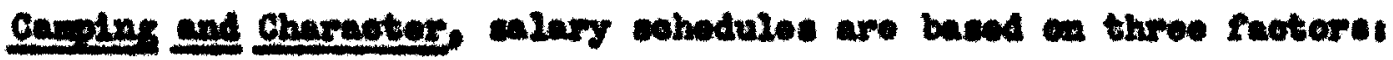

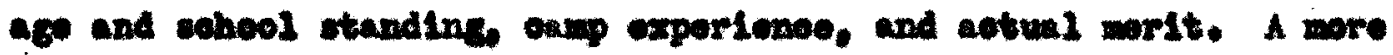

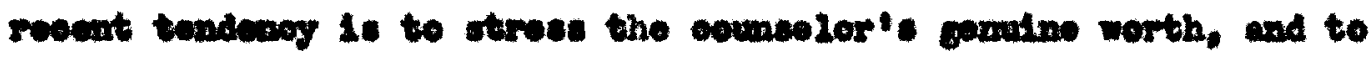

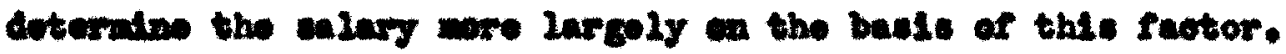


A. Vorry Ladges is the min part of the anmor prograx of Woaloy

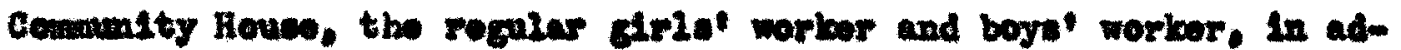

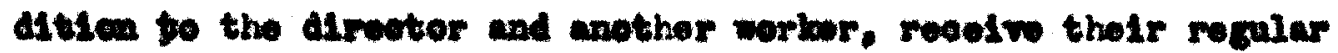
alary at part of the yearly progran. studonts whe hawe been to

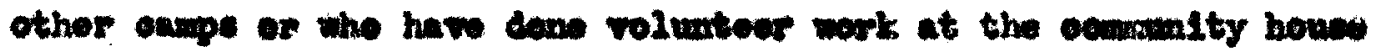

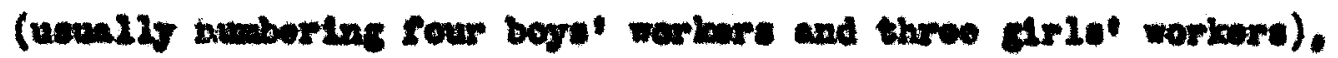

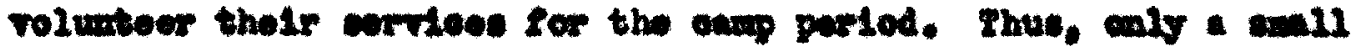

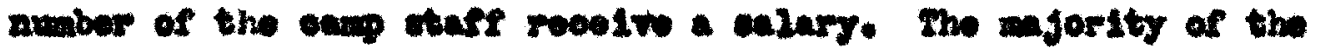

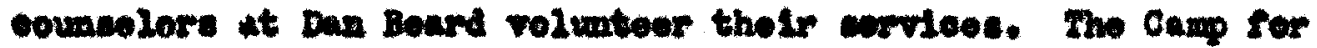

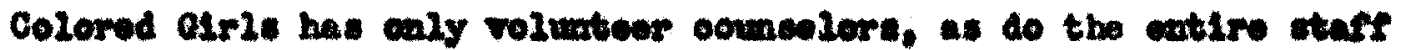

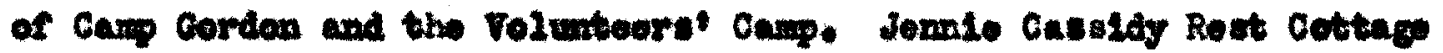

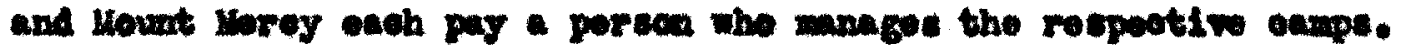

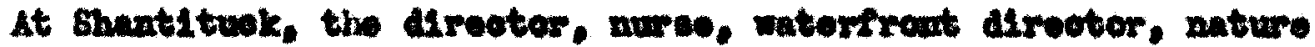
Invtruoter. ocok, and unit leadere recelve alury. Counselore whe

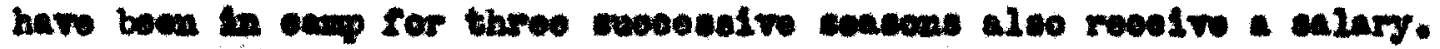
The othor councelore are ecactdored in perlod of tralning. and so

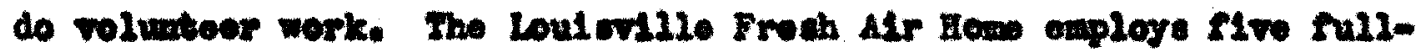
tIm pald workors, and the other corrioes durlag the weasen are on

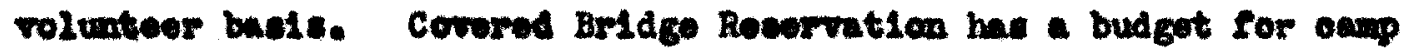

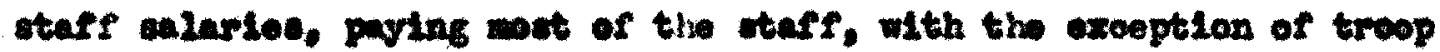

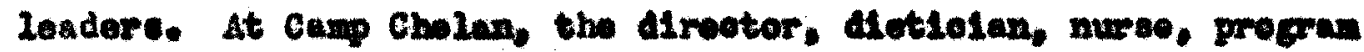
diveotor, waterfrout alrootor. handicraft dirootor, and one othor actirm

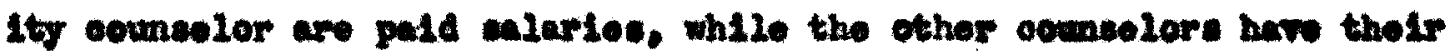

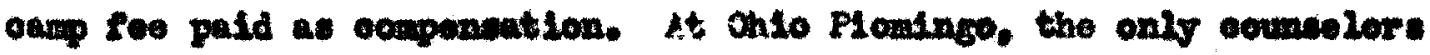

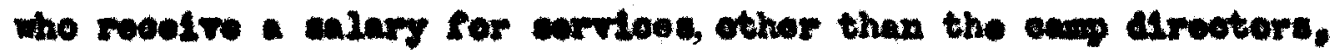


managor, and dootor, are the dirootors of the materfreat, handloraft, and natere.

STAF TRATHIN AN SUPHRTSIOX

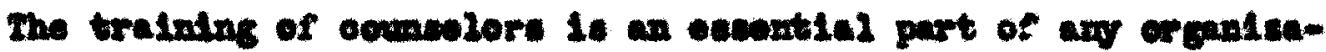

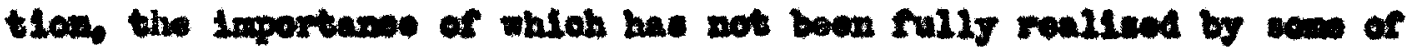

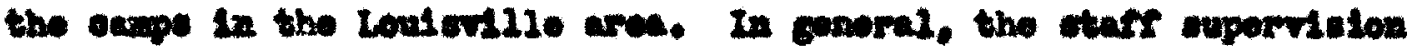

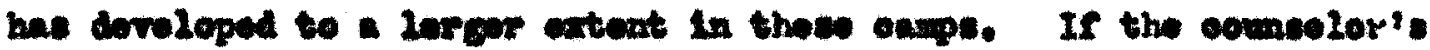

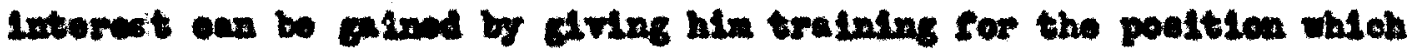

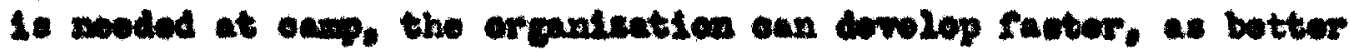

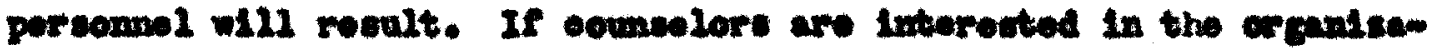
tlon the ondire yoar, and have an oppertunity of contaot with it in

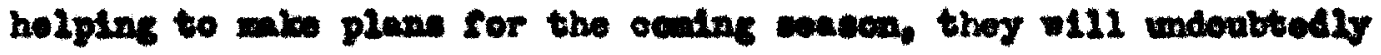
be wore intorected in the oang's progress.

Opportunity for leadorchip oxperlevee with groups throudeut

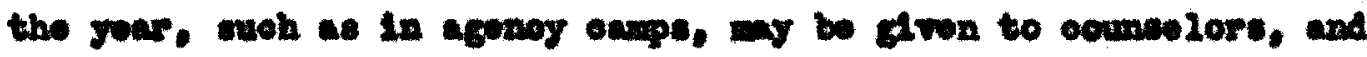

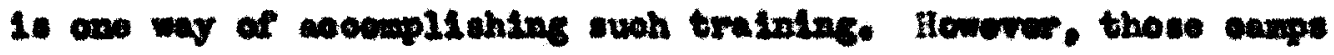
whioh are not aponaored by an aconer do not have thl opportunity. The treop lendere of the Boy Socut bid the Arr Soout or cantentions

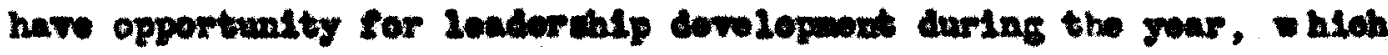

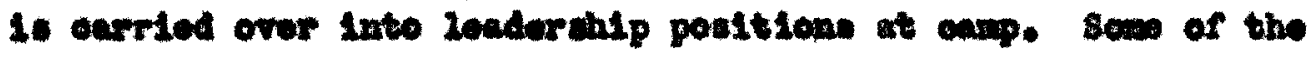
rolumber oouneolore at Harry Ladges, have had opportunity of ex-

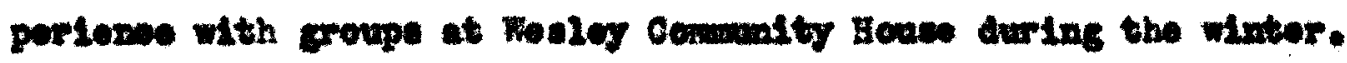


Nelghborhood Bouse has the opportunt ty to train persens es comnelors For the Louisville Fresh AIr Howe, but has not done wo in the part exoept to a very lintted extent. Nout eounoelors at the carpe in the Louim1110 aroa do not have any oontact with the agonoles during the yoar. nor do thoy have any leaderahip experience with grouge in tho organtsation, as areat any of them are atudents. The organisations which sponsor campe have a real opportunity which the other oamps do not have, for kooplng their otaft oamp alnded, and for helping to in prove their walls and kmonlodge.

Holding otafe thetings throughout the yoar 1s a way of partIally meting the noed, but none of the oumps in the Loviovillo area have uned this mothod. A canp reumion is held by somo of the oanps at Christme or porhape tw10e during the year, but this 18 only a coolal weting, and doos nothing in the way of training the leaders. sowe of the canpe have a woting of a fow otaff mombers in the opring to help plan the progran for the ocming season, but the training of oounvelors is left to the indiriduals to gatn themelres. Consequontly, the interests of the oounselors are many and rarled, and the tralning whioh they obtaln during the year has little or no relation to oenp. Varled interests are neoessary in the derelopmont of a oreative program, but apeclallzed training is also vory in: portant.

Ohio Plomingo started this typo of training in the fall of the

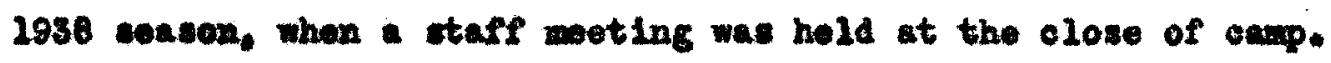
Critlolam of the canp and suggestlon for the comlng seasen wore 


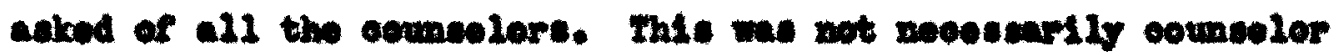
tratulns. but at loat a befinging of wefing the otare to think In tares of onup durtag the rear. swoh a mooting is a way or

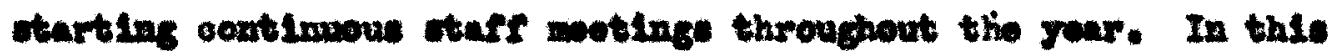

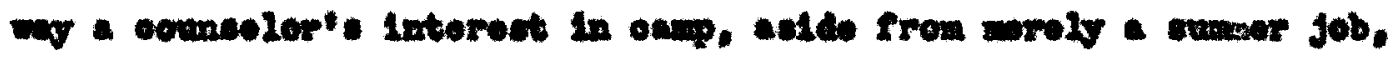
ing be cmoped.

Thu sur. attendanes at Inotitutes, tralning cources, or whoole of soclul and groep work have only boon thought of in rela-

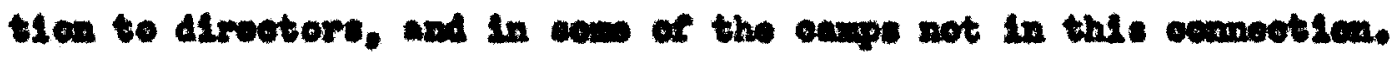
Buoh trainters. whoh is wry miable for laadore, is lindted and

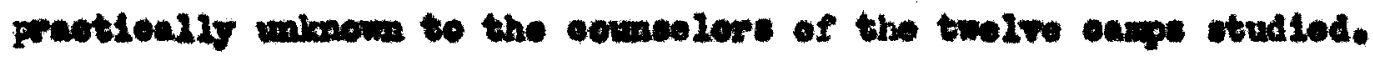

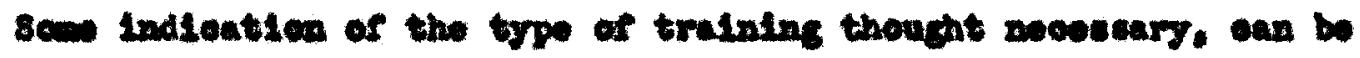

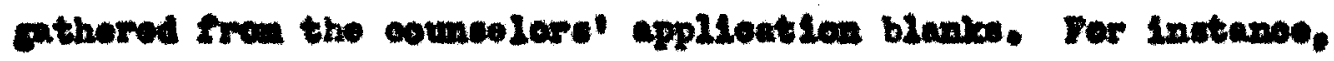

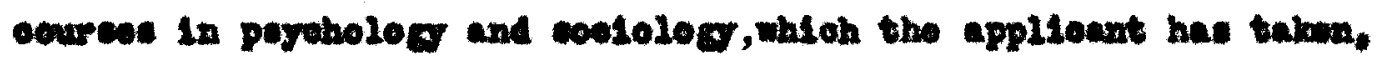

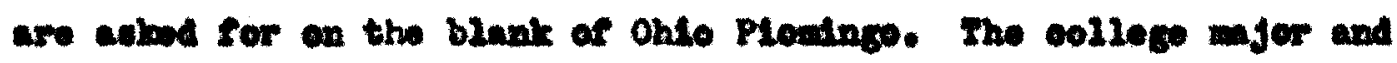

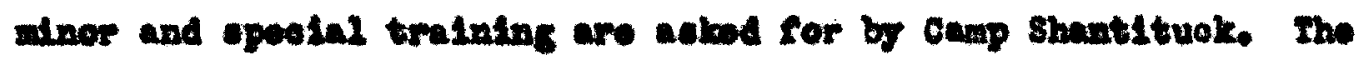
graduate work or epoodil tralning for omg whioh the applioant he

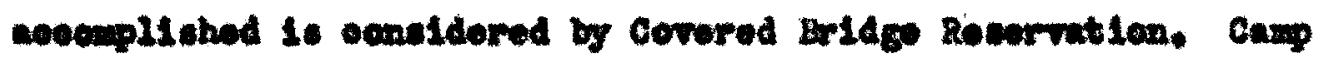
Chalen"s appltentlon blent ack for the cources talma, and the houre

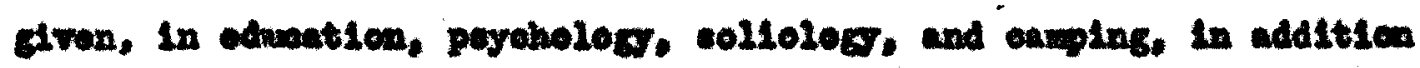

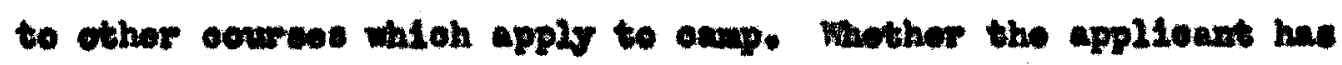

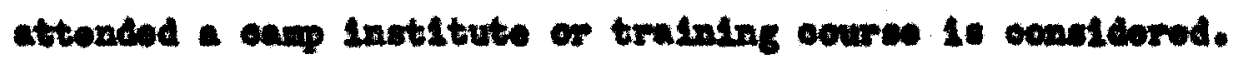

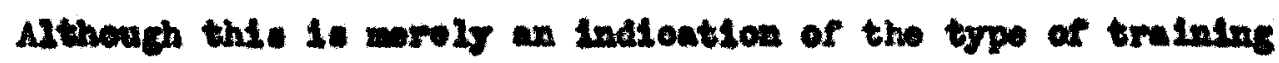

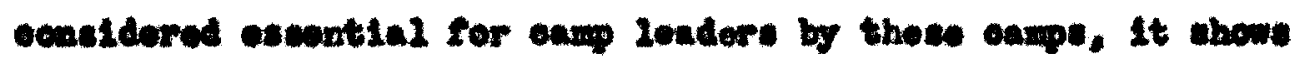

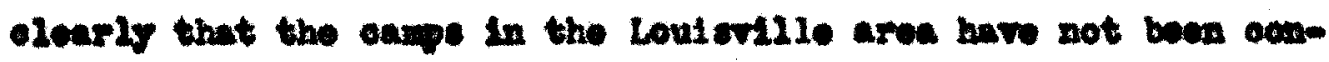


cerned to any great dogree with the tralning of leadere, astde from the experiense which leaders gain at oanp. Laok of cinde on the part of an organization may be part of the reason for the lave of suoh training, as woll a the distanos to oave institutes. This brings out a need for further training oourses and irintitutes in Loulorillo. Organleation: which have faoliltios to oonduot meotings of their om stafe womber durlng the year do not take advantage of this.

The progran direotor and camp dirootor of Chelen attended a oamp institute in Chioago in 1937, at their om exponse. The waterfront direotor of the Covered Bridge Reservation was sent to the Hetional Aquatio Sohool, oonduoted by the Health and sufoty Sorvioe

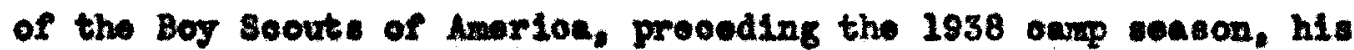
expenses belng pald by the comoll. A general tralning oamp for oelored Boy soout lenders, ocndueted by the reglonal offloe in Cincinnat1, was attended in 1836 by two or three mombers of the staff of Dan Beard. None of the other nine eamps have cent oounselore to training sohools. In-Camp Iraining and Suportiolon

Staf motings are an important fundamentil in the guidanoe of counselors. Such metings may bring about a better understandIng of campers on the part of oounselors. The program planning should be secondary to the discussion of conpers needs and drvelopmont. Regular staff wotingo whioh are primarily oduoational and not doroted ont1rely to eduinistrativo detaile, aro vory benefleial. 


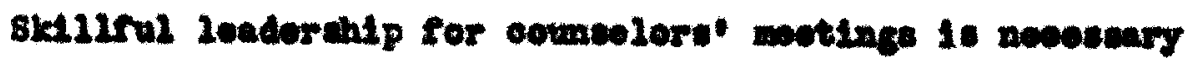
If they are to be Interouting and highy proftuble. The ware moeting it an Inportent mane of ewreloplag "eoprit de oerpe". stare motinge, if proporly oondueted are a pod plobe for the

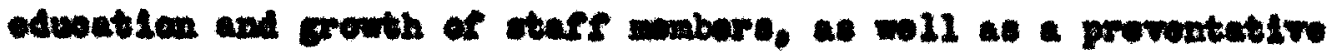

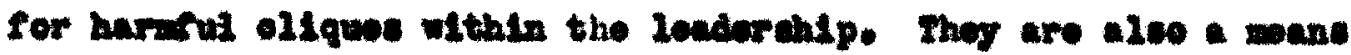

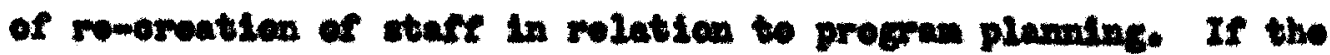

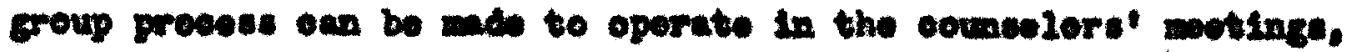
rathor than the auteoratlo whod, grenter eceperatlon and intorent

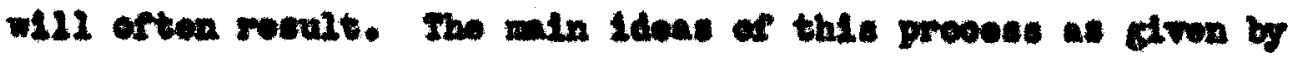
vary P. Fellet in me Der state are docorlbed thus:

The direoter dees not of to the nopting to dwe ordere or monoly atute his idons. Velthar does ho go morely to hoar the ldeat of he counablors. but togother with the compelore to oroste a

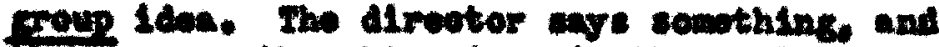
Bhoroupen thought arlees in the melo oouneelor's Ind. Is it the dirvoter's or the male counselor'st Delthary it is alngling of the two. Wo feel thet the divertor's iden, having boen mescuted to the

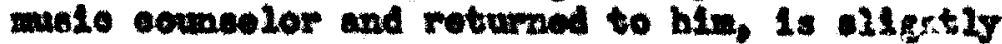

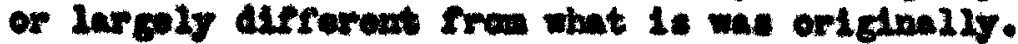
In a Ilbe maner it is affocted by the ouluming counceler and 112 the chowe. But in tho sam way the mote leadex" ldow has been affected by the

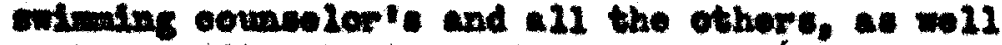
a. by tho Aroctor's, and and an virt11 an 1des cemen to the croup oporgest posevesed and cubm oarlbed to by all, 86 )

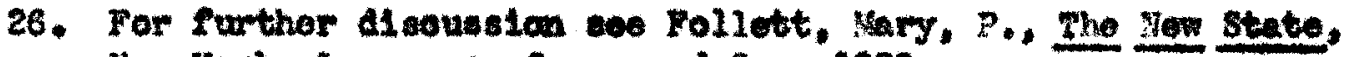
Now York, Longminn, Grean and Co., 1920. 
In 212 of the oampa in the Louloville area the oang direotor 1. the loader of stafe motinge. The nature of these motinge is quite divereteled. At Camp Cholan Imaodiate problem are presonted for solut1on. The procedure is then cotermined by the action of the ooumevior group. Tho direetor tries to nato the provese an eduontion-

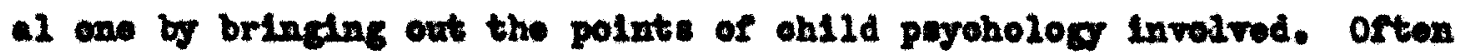
the otaff motting is a diseuselon of Individual aupore or of group problems.

At Vorry Ladges the firet night of eamp, onch councelor is fren instruotions as to what his or hor antios w111 be in the suporFlolon of ohlidren. The requirewent is ade that oouncelors shall not bo ocwandeng and shall suggot rathor than boss. At this motm Ing the combelors are asulged to thelr apeolal inatruoticand dutios,

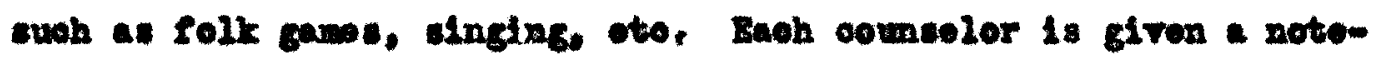
book in wioh observations, and oomente on each glrl are made during hor otay at oamp. Wach oouneelor wakes a roport on the whole croup. If ang oblid presents a problow the oomealor group is oallod tom gether for oonoultatien. in order to got everyon's rewpolnt on the oblid, and to help flad a welution for the problem.

The stafe at Dan Bourd has delly staft mootings, whoro reports en provious aetirities aro clven, any problom whloh havo appeared are disoussed, and plens for the cotirities in the future made. It 1. a rule at oamp that divolpline way only be admintetered by the oump otafe wonbers aftor reporting the diffioulty in the stare cooforenoe. One staff noeting is held before the opening of the caup 
Per colored CLris to diseus plans and abqualnt the now oomeolere

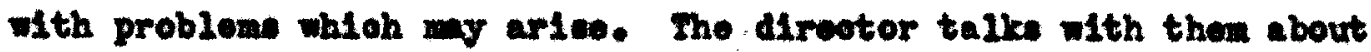
the Importance of eocepting rosponsibility at well as if they woro bolng pald. Additional staft mootlage aro hold overy weok. Irery night last season at Camp cordon, the three stafe mobors disoused the onnpers reactions, sttitudes, and program, staff nootings are

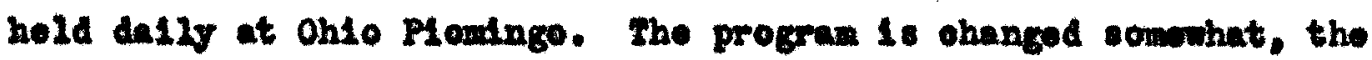
boye diseused, and problew brought forth. starf moetinge are hold dally at Shantituok to oviluate the progran and disouse tho way in whioh it is being oarried out. At the Loulwille Froch 11 r Hom, steft motinge are held every weok, whon the now group of volumteer oounselore arrive and the other group 10aves. Additional mootlugs are oalled whon neoesary. Plans whioh have not suocedod provlously, and those for the following weok are disoused, start motings at Covered Bridge Reserration are held the elrot part of ewoh oamp perled to plen tho progran for the loders. Any other nooeseary motings are ealled.

Recourees for Irainins

4 well ohosen 2 ibrury is vory nocessary in a oamp, for ooumcelors to refer to for now ldoas, holp in the treatment of oampers' probleme, and program matoriel. Such a 11 brary should contain acoquate matorials on the cenorel f101d of oamping, on spocial activities and related sields suoh as ohlld poyohology, dueation. the Aseusulon method, and group leaderahip. 
The Inctruters of the various etsivitles of Covered Bridge Rosurvation help the Alreeter choose books from the Loulurille Free Publie Library for the wee of the sterf and oampere during oamp. The book are efren out at the trading post by the oamp olerk during

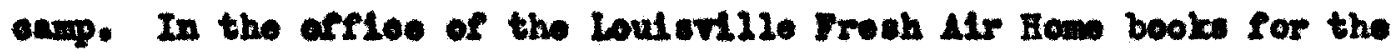
ctaft are arilable during the ounp ceason. There will be a Library for tofe wes in 2980 at Camp shent1tuck, and a oump stafe book for enah councelor, centalntag a map of tho and, coplos of all reoorde kopt on the oarpoirs, name and addreases of all 10adors, and job andy 10. A 21brary for staft woe 18 avalieble at the offloe of Ohio Plominge, and a library for the boge loaned by the Loulaville Publie Library. The Ireotor of the Cayp for Colorod arle oonfors wth the 21brarian of the Loulovill Publ10 Library for aholoe of books, and at loust fifty are taken to oanp at a tin. The oampere may tale them out owry worning and overy night durlng oamp. Sono beoke are taken to Dan Beard for the une of the otafe by the mambers themeltres. The direotor of Camp Chelan furnlehes sows books for the nee of the stare luring carp, but an indequate number, aceordIng to the Alrootor. Books are taken to Nerry Lodges for the uee of otaff and oampere from the commalty house which malntalns branoh of the Loulovile Poee Publie Library. Sow of the direotor of the exmpe studled have a number of good books, but it is doubtrud if they are used as moh as they mifht be by the oounselore at camp. 
With the orowded program at the majertty of the oampe, 1t Is doubtful if the oovmelors have adequgte tim to road durlas the samp perlod, alde from gotting gonoral ldows for progran purposes. Wore strese neede to be put upen booke for the councelore' use, and the giten to use then, as well as onoouragenent by the

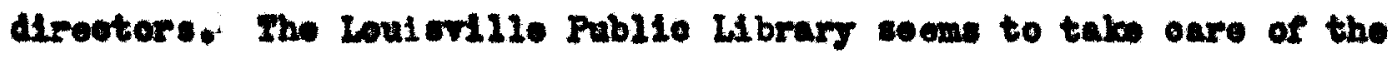
expere' book edoquately. Councelor-In-2ratnins

Stafe tralning, a vory algalfloant part of ang progran, has been undertelvan to little or no degree by the oampa in the Loulorille area. Int: is a Hiold in which there is great need, and whioh chould be developed in the future. Gamp is the logleal place for woh trainIng to otart, as oamp direotore ahould be, and mang are, qualified to touch or at loact start suoh a progren. Baoh oaxp should have a dofInt to training peried before oam for councelor: Campers who have attondod saup for a number of yoars and who hare oldils and leadorahip posabilities, chovid be given an opportunity of training for

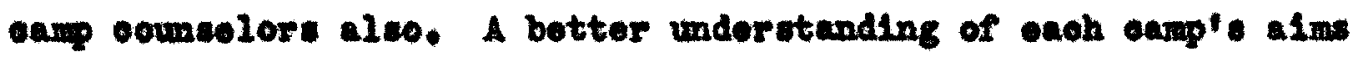
and objeotlves would thus be brought about, as woll as a greater

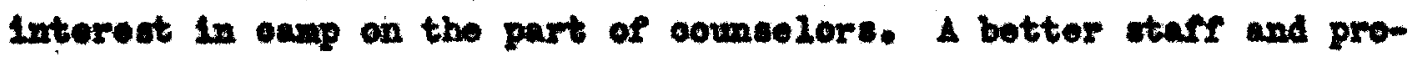
gran and more affootiw earp would recult, espoelally as the wohinery already exiots in wang of tho oxupe.

The gonoral oamp experience fives the oumpers an opportunity to develop sall in rarloue cotivitios; to learn an approelation. 
of the 1doals and purposes of the oump, and to gain an undortending of oamp wothode and organisetion. If the oumpor is given the opportunity to help lead other groups, a ehanee for leaderahlp developmont is apparent. Conoral training courees in group organisation and 2oaderantp my alce be inolndod, led by the oam direotor, or by

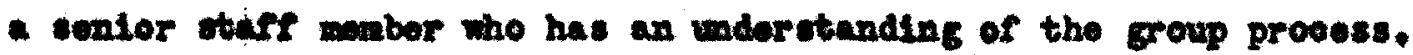
These noed not be lengthy oourses, but a holf-hour alsoussion ooch

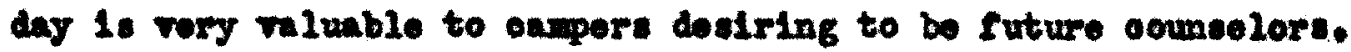
Camp unry Ledges offere no staft training bofore, during. or after samp. At Ohelen the wook-end provlons to the oponing of aamp, conferveces are held to arrango the prograx, and Individual Interviows wth proupeotive or new oomedors are held by the direom tor. During oum, there are at lecut two lnterviows held between the progran alreotor, oum dirooter, and enoh oouneelor. The direotor of Den Beard Interviows some of the boys before oump opene to

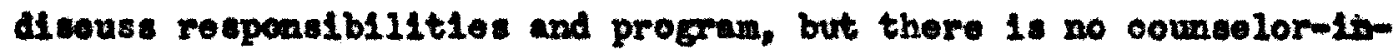
training or otaff tralning progran as suoh. Campers who show ablilty are nomotine ohosen al londer the next year, and may go to oump without oharg. At the Camp for Colored Glrle there is no training

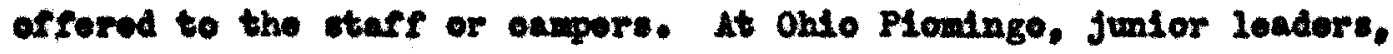
who assist in activities during the cump soason, are ohosen by the direotor as oomeelore for the noxt year, if they preve to bo ofrlolont. These juntor leadors attend some of the councelor woetings during oamp soacon. A tratning sossion is hold throe days provious 
to the oponing of oxp. Btace training is included in cally notInge during oumg and at woctinge dming the winter at the I.M.C.A. starf motings do not continu throughout the yoar for the por-

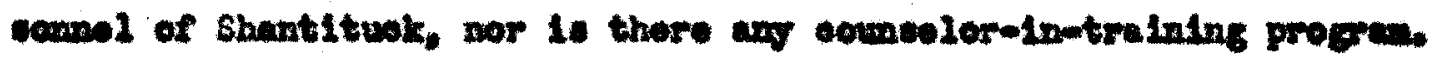

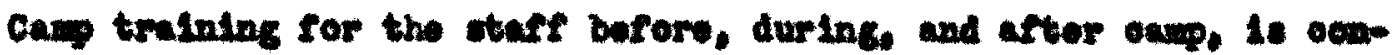

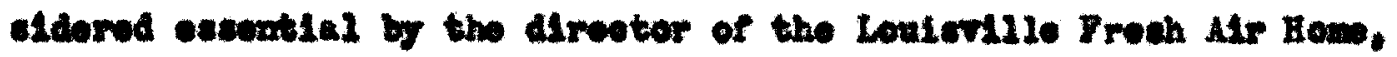

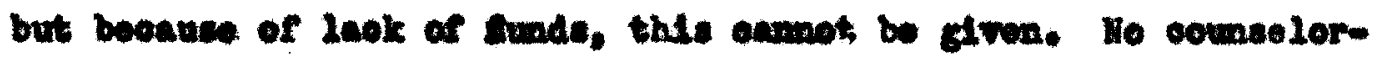

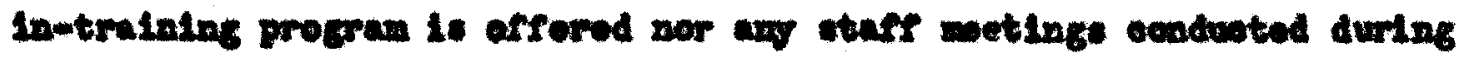

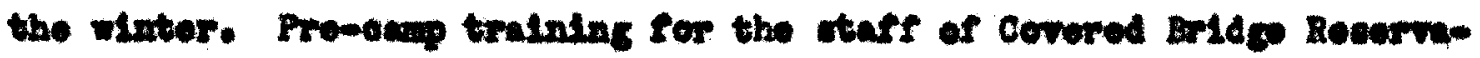

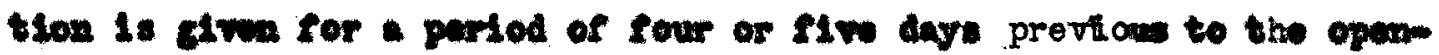

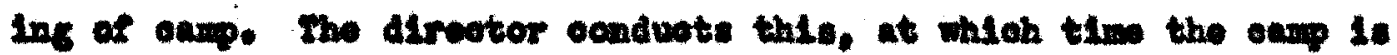

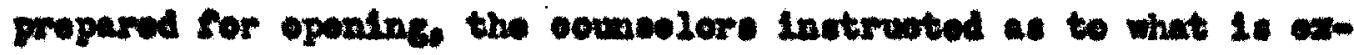
pooted of thom, and the procran for the oculng concen planned.

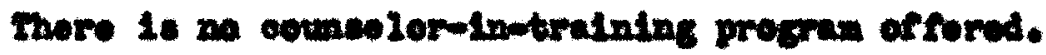
Contingty of stare

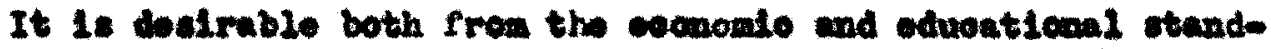

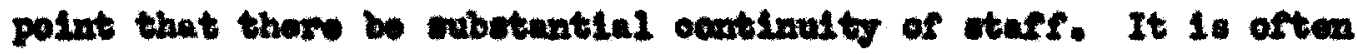

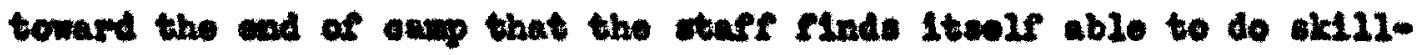
ful and conosrted work. The underutunding of the grovg, and the wathode which they are trying to we are orten oulatnated at the ond

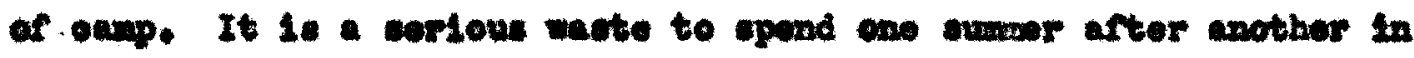
potting now ctaff monbore trained to this potat. In the program as

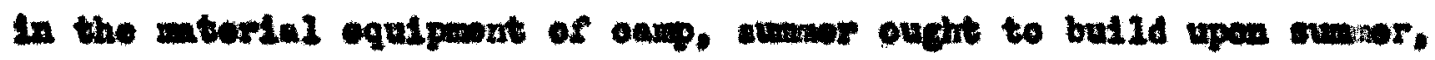
and parpe chould not have to ctart ench year ilnost at the woubling

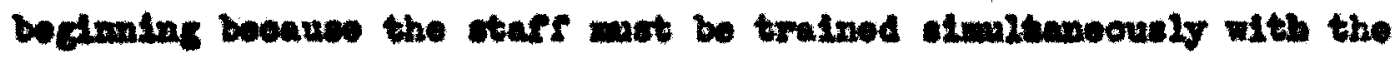
arvieping of the progne 27)

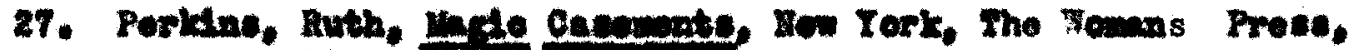
1027. P. 120 . 
Whon the atafe has been in camp for a number of yoare, this uounlly denotes a genuine Interest in the oamp on the part of the counnelors, henoe a good progran, which thoy want to be part of. It also man a botter understanding of oump objeotives, and competent leaderahip on the part of the alrector.

Sereral of the starf of Covered Bridge Renervation have been In oamp for one or two grars, and sereral for four or 11we. The dreoter of the Louldrile Freab Alr Hom has had the position for three or four rears, but as the majority of the oouncelor are roluteort, the ohange is conslderable ouh yoar. Likowlso, at Camp shantituok, the majority of ooverelore are now ovory year, with

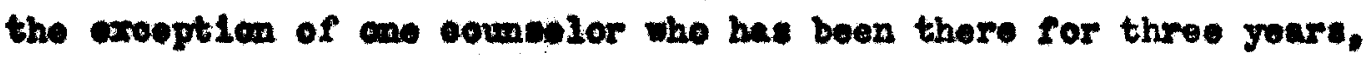
and owe who hes returned for two. The vajor portion of the stafe of Ohlo Plomingo wal now in the 1938 censen, as it was the firet year the organisation had uses the Atter Creek oamp. One ooumselor at the oump for Golored Clris has boen on the ataff for four yoars. but the majerity are now each yoar.

Wout half of the oomselors at Dan Beard have roturned for the part fen yoars. The arerage length of atey for commelors at Canp Ohelan is two or three years, but several have been on the stafe for ten or twelve yoars. Worry Ledgen has been in operation for four years, during whioh tino the adninistrative director has bean the bead. One stafe nomber hat been on the etaff for two years, but the majortty of counceler: ohange each year. 


\section{Reareation}

Yost authorities egree thet at leact one day durlag the wook or portod (ouoh as a ten day perlod) should be gtren counuolore to remew their 1dons, apd to "rosoreate". The otafy should haw sone tin during the day to rest, road, or wite lottore so that their duties w111 not be toe tiring and thoy w11 enter into them more

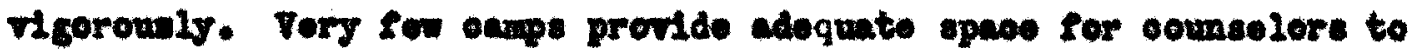
have disousdions, or even to rent. Lthough oounselors are in eape primarliy for the boneflt and oure of the eampers, tholr noed to got together with groupe of thelr om age are juet as nooessary as those of the oumpers. Condtions in oamps rary as do polloles in reapeot to froo time given to the ataff. Cownelors neod at leat one hour a day of somplete freodem from responsibllity. Infy oamps have tim botwown oamp portode of a day, or a day and half, in whioh no oampere are at oump. In addition to this time, mot oampe aln to prorld the equivalent of three porlod: (morning, arternoon, or orouIng porteds) for the oounselor's free tim. Other oamp allow a full day of twentymfour houre cach two-woek portod.

If the oawp direotor is alert to the noede of the counselor for 101 sure time, the freshness or spontanelty noceneary for a suscessful aang will roault. The dreotor noeds to have reoreation as woll as the rest of the starf. When there is only ono modical person at eamp, that person should not be glron timo away from the oanp for a longer time than ono por108, and then only whon thero aro no pationts to be cared for. 28) Therofore it is dectrablo to have a substitute

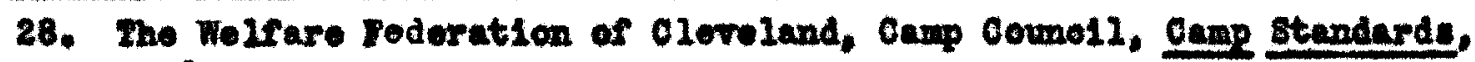
p. 2 . 
for this porson, or to give him adequate reot during the oamp por10d.

Bom anthoritse bellere that stafe mombers should IIv amang the eampers, but not in the same tents, as the otrain of 11ving with ohlidren Is an unnoovesary one. This is a controversiel polint, but If the dasly guidanee of oampers is good, there 18 lose need for the oomeelore to live with the campers.

The only fre the for counselore at lerry Ledges is in the oroning after the ohildren go to bed. The ctaff mobers aleop in the sam room with the ohildren, ourtain dividing the seotions. At Chelan, the Alreptor oheoks to seo that oounselor's dutles are -qually dirided, and that oach cowneolor's sohedule is not too heary. The oownelore have twenty-four hours free tim a weok. The staft headquarter: in each unit, whioh provide leoping quarters for the oounceler,, are olose enough for supervision of the campers. It Dan Eeard ewoh stafe member has ono afternoon and evening free each wook. A tent for the otarf combined with hoadquarter provides eooonmodation for the otaff mobers separate from those of the exupers. The atafe nombers of the Camp for Colored oirls have ono day a weok in town after broakfaot until fire-thirty in the ovening. Thore are no separate quarters for etaft aside from oumpers. The stuff at Ohto Plomingo had only a fow daye of froe tiwe during the 1988 wescon, but the alreotor foels that stafe momber should have one day out of overy ten at least, and this polloy is to be ued in the future. The commelore live in the oabins with 


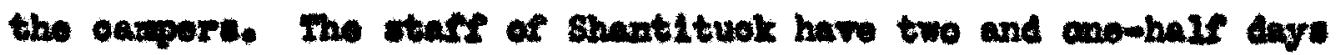

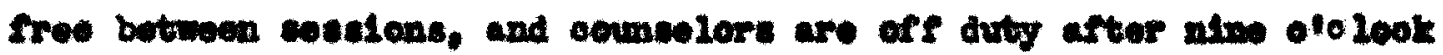
If the wat is ecwered by som one. Two to thrae doweclore aleep in

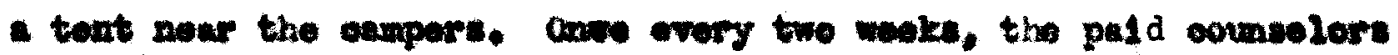

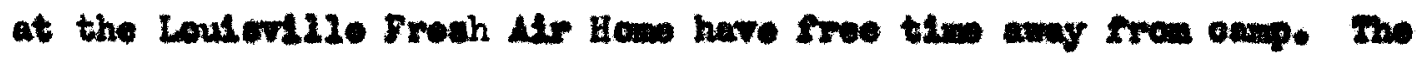

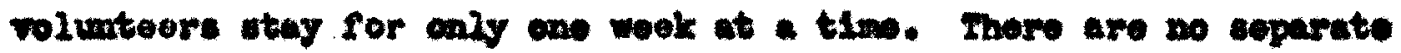

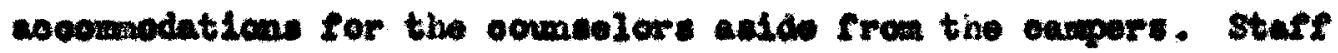

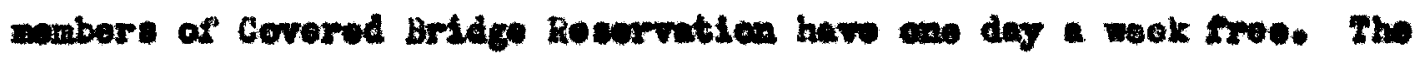

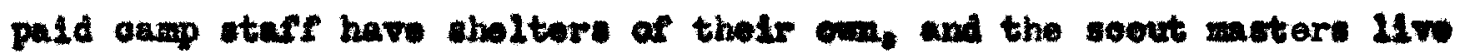
In the units with the bega, but in their own sholters. Stafe Apraited

Perhap the appriteal is the not impentant part of the otare

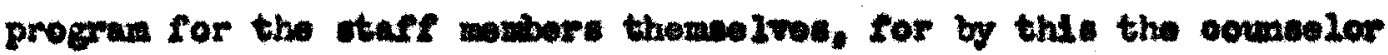
oun be holped to reallwe what be lacks in dealing with the group. By such a mothod, maber: ahould be eneouraged to luprove thetr walle and attitude so that they way be better qualified as leadore

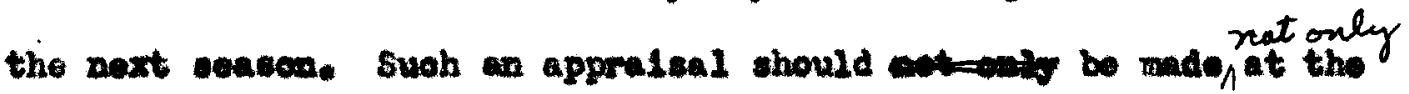

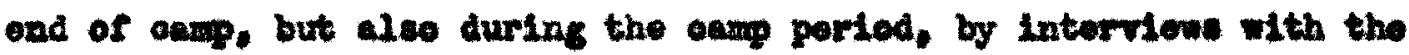
cam alreetior or porecanol ilnotor.

This is we wothod of a indirsot nature of tectint the efreo-

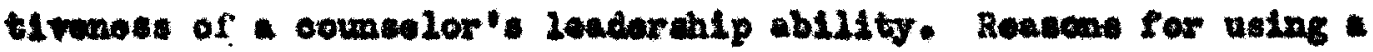

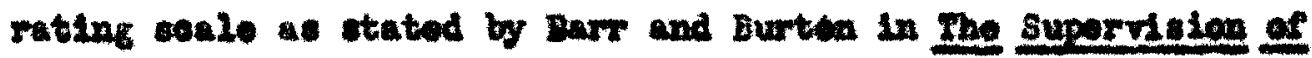
Incturution are 11 ated by Dimoh and Hondry ast.

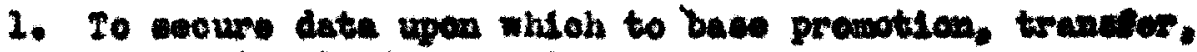
or dimuser at ecementore.

2. To boure ate upan which to bace and oporate a andt whow of salary Inareaces. 


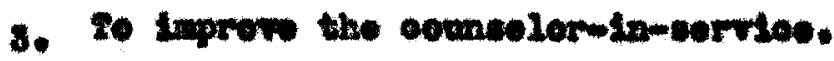

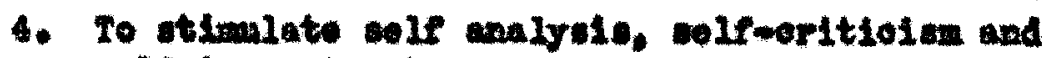
ale ingrevinost.

6. To ralce leadorehtp otendarde.

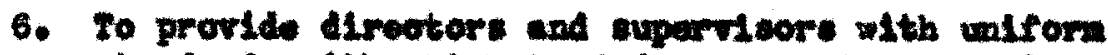
rtundards with which to judpo oounselor: analye. their worls, etimiate inguovenost.

7. To provide oqunelore with a tatomats of the otandardi by whioh thoy ara belng judged, toward widh they chould dovete their efrorte to improwe.

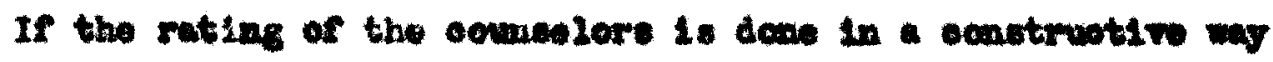

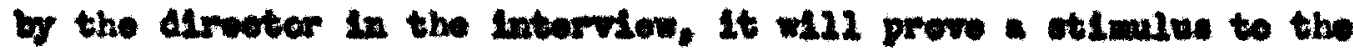

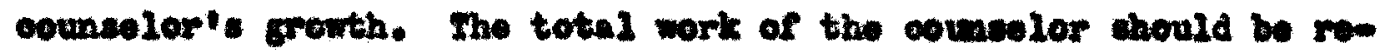

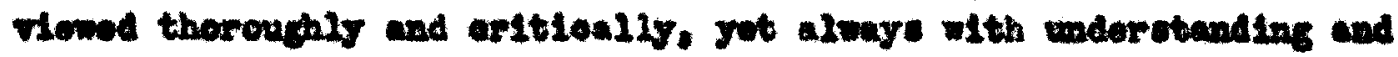

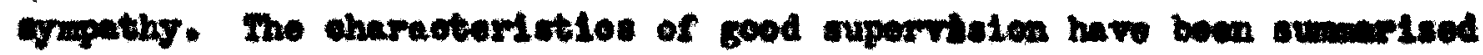

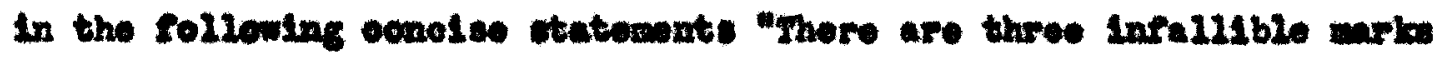

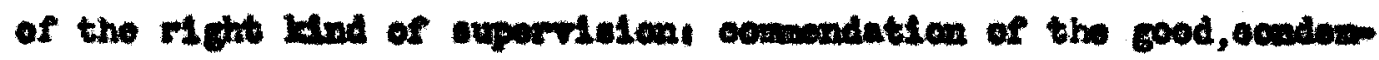

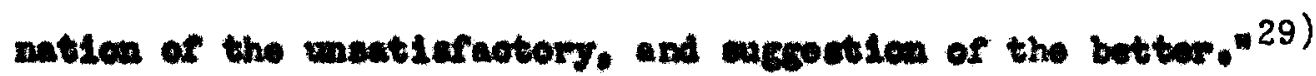

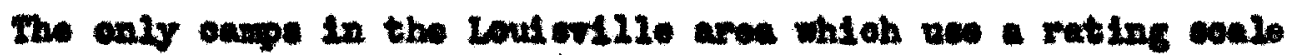

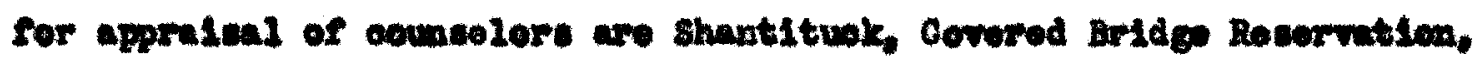

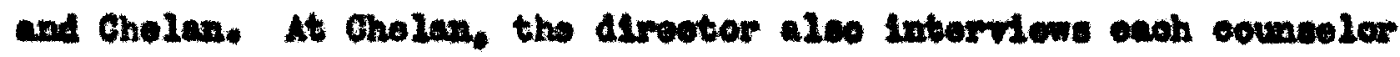

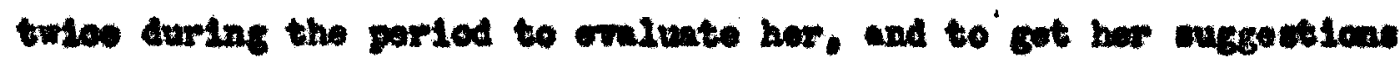
an the pregram. Problem are alsoused by the councelore of cowned

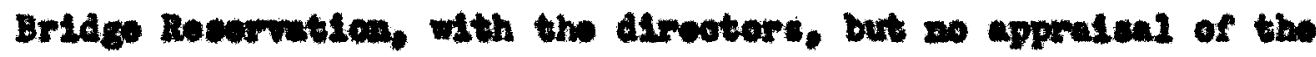

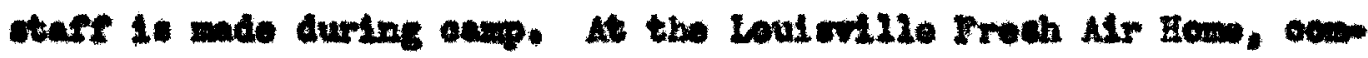

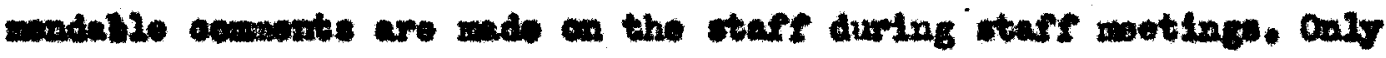

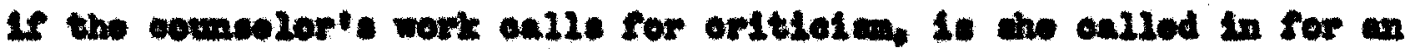

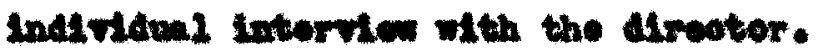




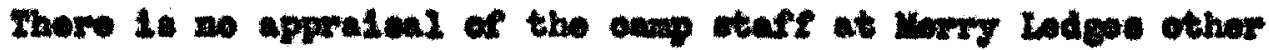
than that of the otafe mobers, lnaluding the dirooter and throe of

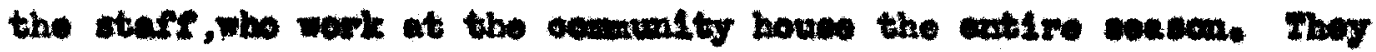

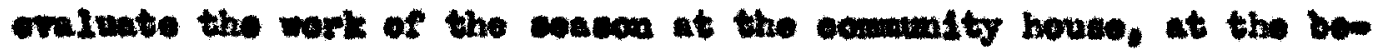

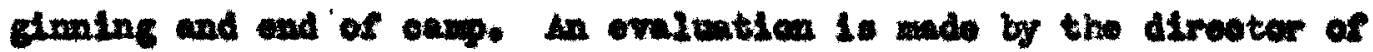

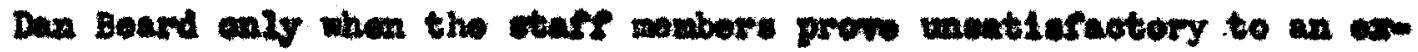
tent that the direoter anet ooxfor with thow individuelly. Those whe hov don notheably good work and wo haw malo oonalderable progrese are prel wod by the oump director, but wo ocarorenos beles

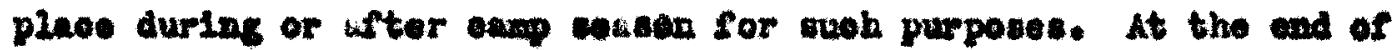

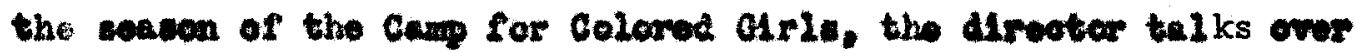
the atotales of the counelors who whah to retura nuxt yoar. but we Interviews are beld with the tafe durlns the coavon for craluation. At Oblo Ploulngo. the dirootor roporte a ecatent sppraleal of the

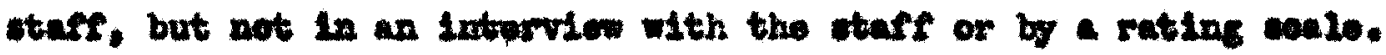
Thus, wth the exeeption of Canp Chelan, 11ttio is dom in tho campe atudied to let the coumselore know wht in though of thelr work. Unless coundelor proves to ke hardul to the aup or

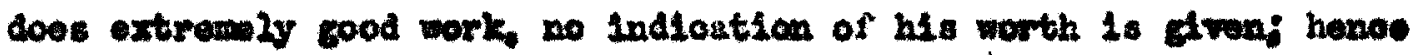

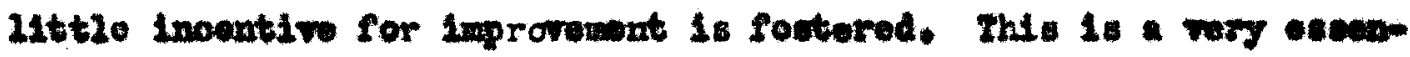
tinl part of the progrum and one whoh is not only rery benorielal

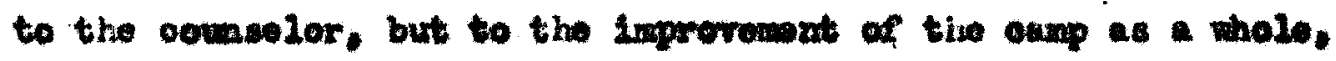

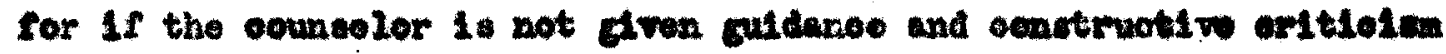

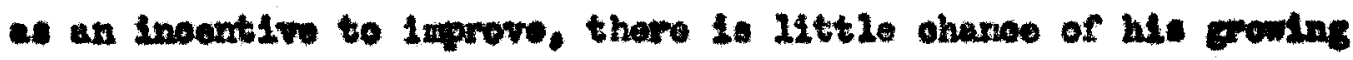
ales wh the porome. 
Butwares

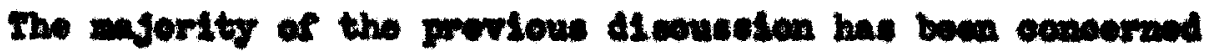

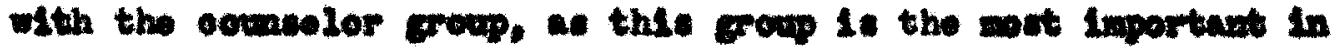

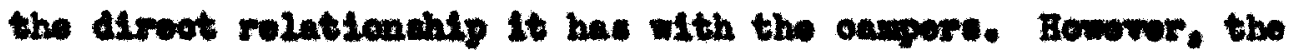

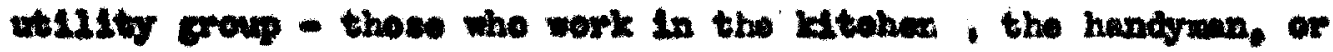
aurotalor, and otho: holpe are alco quite ingortant. Whore the

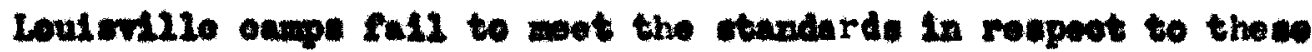

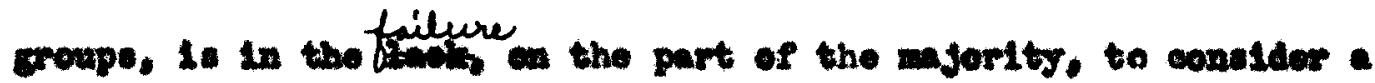
Phyateal examination importunt enough to be required of thep, Inte

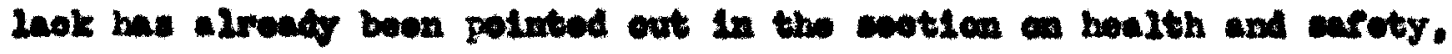
but 14 enmot be roroesed too makh.

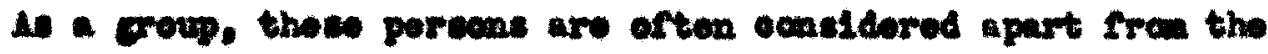

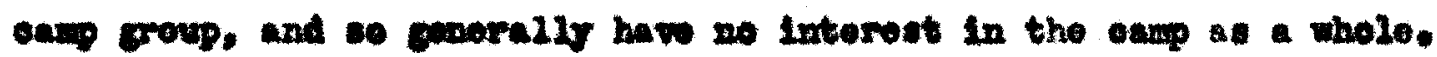

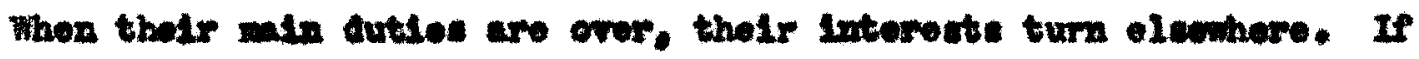

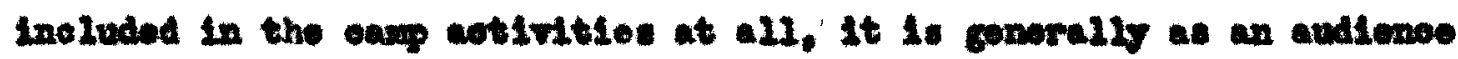

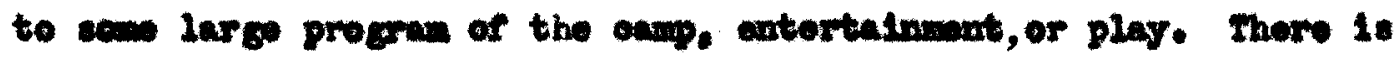

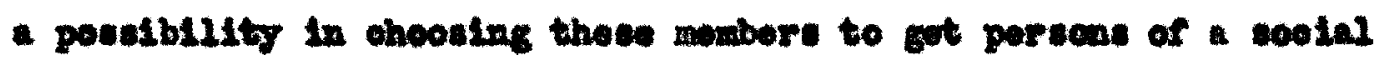

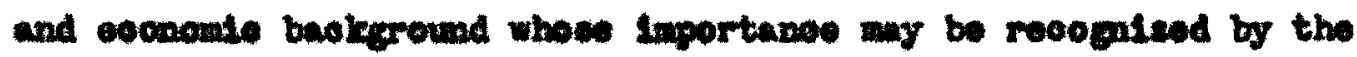

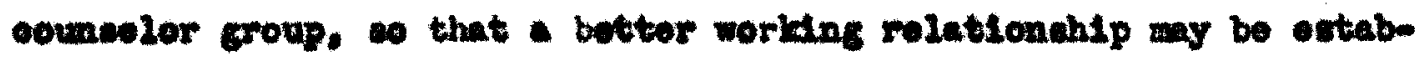

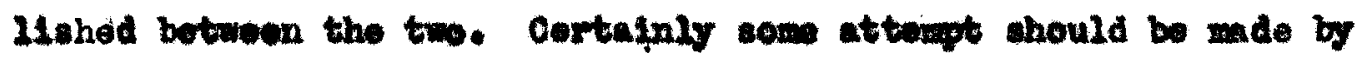
the dreotor to underctind the fooling of such group in relaticn to the oarp. and to galn their interest in the we Lfare of the eavip

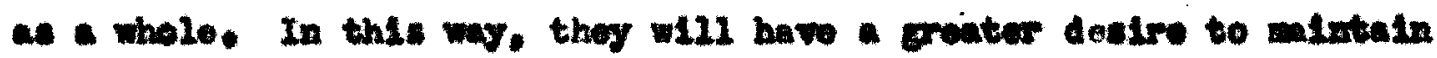

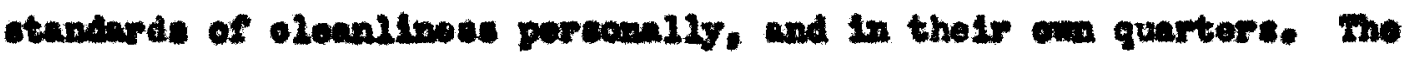

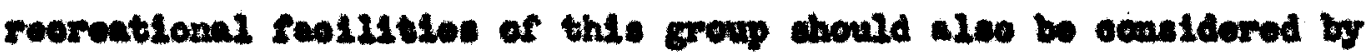


the direoter. Sew troe tiw should be given owry afternotn, and If posalble, onoe i wook, a oomplete aftermoon off. Provialen oould be mide without interforenos with the eapers for emplegees to onjog tiahing, enduding, boating, et cetera.

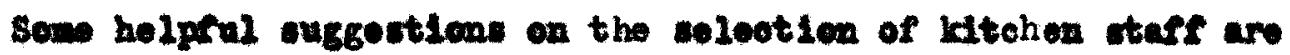

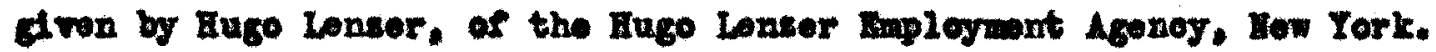
He ays, "Tor andl canpa whioh have fifty or lose ohlidren, the problen resolves Itself inte providing oook and two litohen holpors. For cape where the onrollmont is frea serronty-flw up to four or

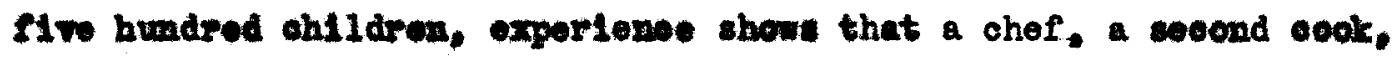
a bator and the appropriate number of ninor asel atants oemotitutes a normel stafe." 30)

lost of the andps weet these requiremonts, the majority having cove cook and a handyman. Cholen has threo oooks, Coverod Bridge

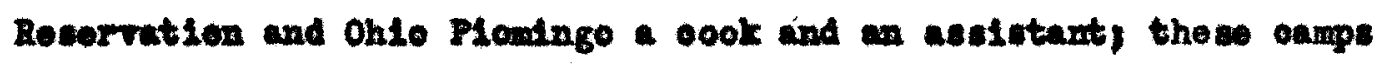
belng the only onos heving one hundred or wore oampers porlod.

1r. Lenser adde. "In the finel annlsele, the proper seleotion of your holp Involve a tremendous anount of sorutiny as to the

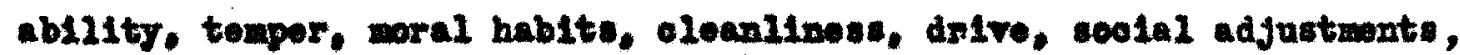
and personal integrity of the prospotive apploseo." 30 ) It if deubtrul whother wny of these feotors, aslde from the porsen"s ability to oook for a large muber of porecas, and porhape his oleanlinese, have boun conclered in the oholoe of explogees by the majority of the direeters of the exmpe ctudied.

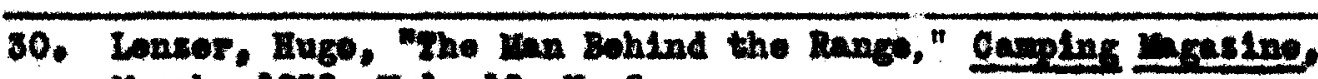
Eroh, 1988, 7ol. 10, 10.3 . 


\section{sompana}

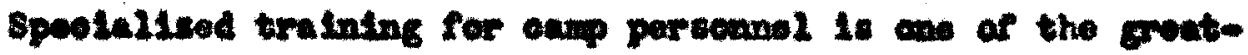

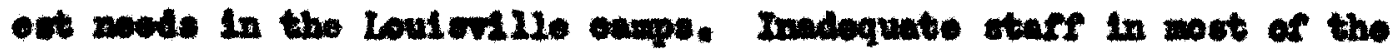

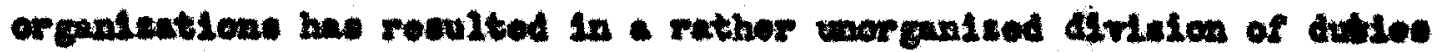

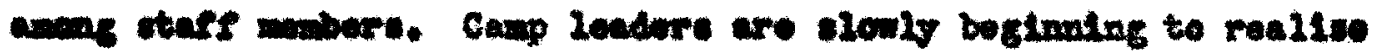

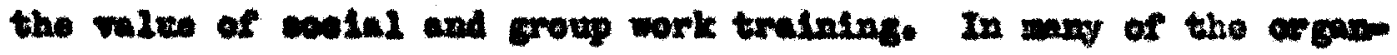

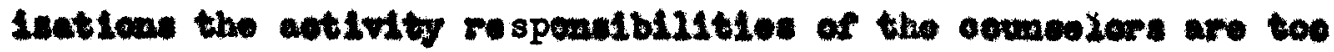

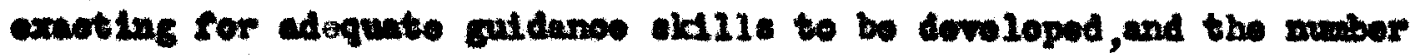

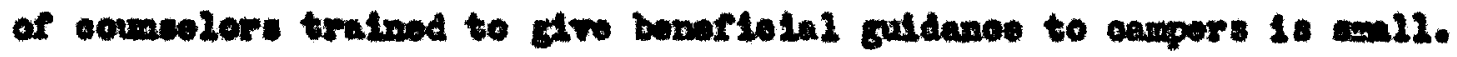

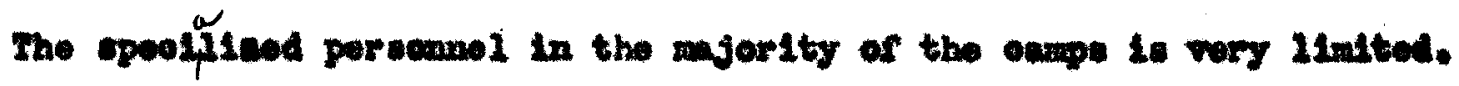

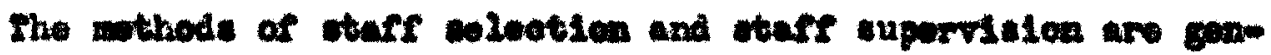

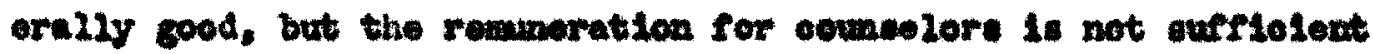

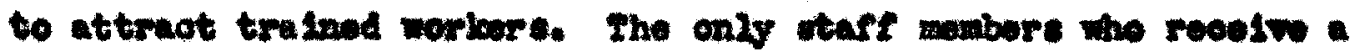

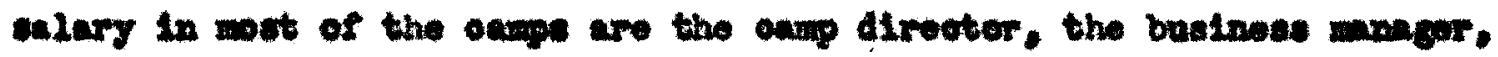

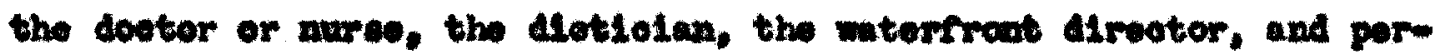
hape a progrea dirostor. The traluing of eamp presennel has not bon

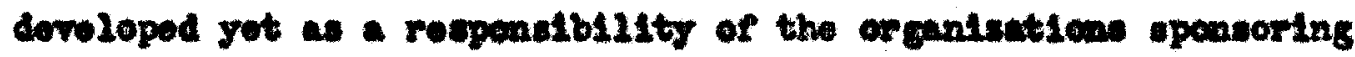

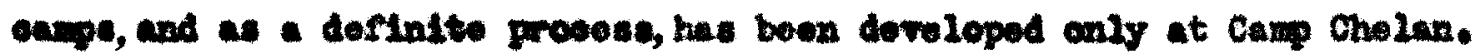

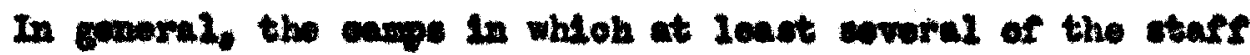

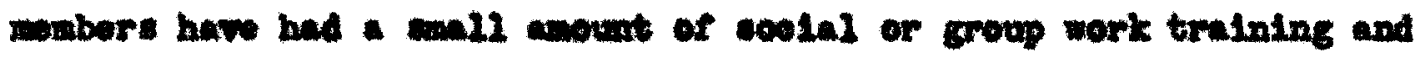

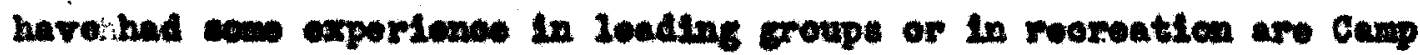

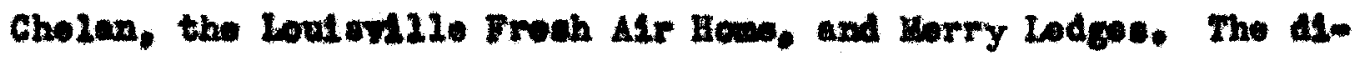
rootore of Ohto Mondinge and the Cans for Colored Girle haw hal sons

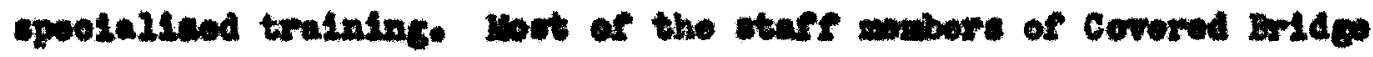

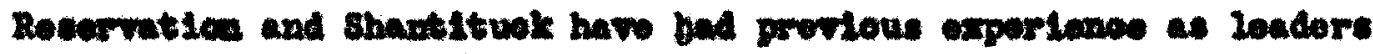
of moout troopa. 
V. ProcRai 
hooray

In plenalng a camp progran, the objeotive are of greatent Importanee, for it is they wioh primerily determino the type of peo-

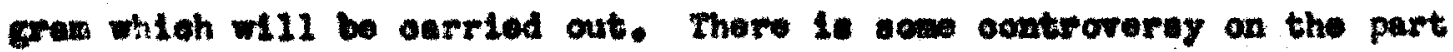
of oup authoritide at to who ahould talo part in the planning of the program. The aotivitios offered by the organiation conettate a large part of any oav?, but the guldance and rroupling of oampers, the wotivating faotore of the program, and Anally the evaluation of 16 , are al1 Inportunt partse of the entire plan.

the progran is aletinotly interraloated with, and Influsnod by. the parsonne 1, the adesiniatrition, health end oafoty, and the tho and equipest of the oamp. The perennel detersine the ofrootivenese with whioh the peogram is arzied out. The sduinietration has a prout inplueno upon the deteraination of objeotivea, rrom which the program is plaswed. The health and afoty of ampers and the 1 to and equipmont of the oump hare alroet rolation to the 1initations of the propran.

\section{Ob.JCEIVES}

If the objectives have bean formulated by tho eap direotor.

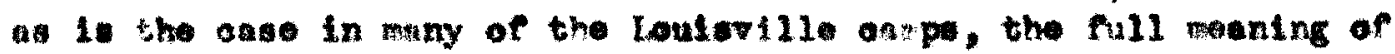
those and nast be underatood by the rost of the ataf as well. If 
the phllosoply of the stafe members on be a part of the objectives, they will hare more meaning to each of those individuals. Too often direotors and atafr beoome so interested in the deta1lo of the program that they forget to think of the objootires.

Vory often objeotives are otated werely sa phrases wich sound

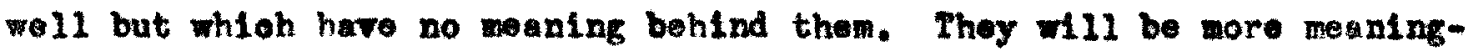
ful if thought is given to need in the community. A better program w11l veually be the result, and the oamp will more completely provide for the true comanity noed. One organization eannot deolde upon objeotires for another organlation, but certaln basto prinotples are oonoidered osential for all oumps. The ohlld should be regarded not only as one who comes to oamp for fun, or to Inorease cortain ikilly, but 180 should be coneidered from the physionl, Intelleotual, moral, and omotiond atandpoints. Xnowlodge of the ohild's background is just as Important as his rosetions to oamp experienoes.

The Boston Counc11 of Soolel Agenoles, at a reoent oamp inditute held to determine objeotive for non-proft oamps, conolude that 211 oampi should: firet, socoumodate ohlidron to sohedule of aotivity by regulation of meals, earflolent 100 ?, and other health measures; second, teach ohlldren that heppy corporate IIring may be had only by resolving differenoes; third, give ohildren responelbilitles to whioh they oan respond; and fourth, instill into each ohild a sense of freedon and provide opportanity for self-direotion.

Opisions differ as to who should formulate the objeotives of a sumer camp. Frogressive camp leaders think that the camper ohould have definite part in this undertaking. If oampers and oounselore 
have the opportunity of taking part in the formation or revision of objeotiven, the onp wil probubly be more algnifiont to thom. As result the objeative w112 probably be ourried out to a fuller extent

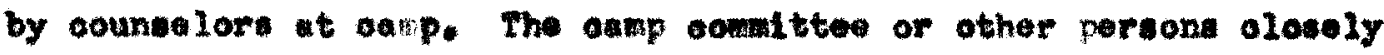
related to the oamp hould loc havo parti 1 this formulatlon. The Intorat of pronte is aleo galnod if thoir wiahos in rogard to objeotives are ooviderad.

There are vartous ways of obtalulag the oplnione of these groupe, through Interviews with the camp direoter, through group weotinge, and through quetionnalres or blenko. The most effeotive way would seen to be through froup wetinge of the direotar, oounselors, and campers, keoping in wind the rlows oxprosod by paronta or womber of a oamp oomitste who perhape oannet be presont during the onp cosoon for auoh - purpose. This thod may not be pratioal one for use in some aamps, but It way at lonet bo ned for a roview of objootives, oo that the in dirldualo in oap aro exmare of the sima.

The objetives of wost on are ather set un beforo the osmp i. In opuration, or at the tiwo oarp opona. It is neoensary to roview and reriso objetives yorly to ineorporate now Ideas and views, or to Infort parsonnel reontly reoruited.

The objeatives of Covered Bridgo Kesorvacion are oftitenthip

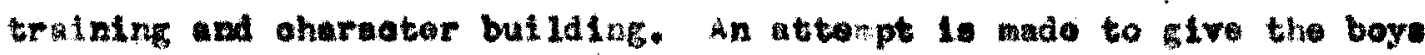
a happy and holthy oanp experlanoe. Theoe objeotlves were set up by

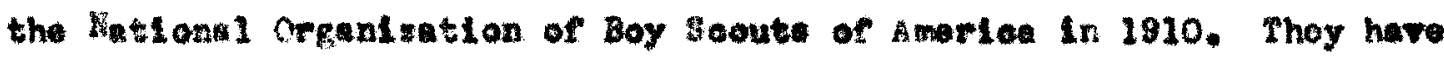

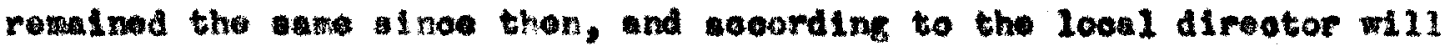
contime to rowaln the sace. The pare and councolors hove no part 
1. roming the objeotives as they are hended dum by the natlonal organlantion. The objectiven of the Lenleville Preah Ar Fome, as ateded by tho admintrative direotar, are: to give an underpalviloged group, fresh alr, aunokine, and othar natural benefits of the sountry whioh they sro dented beane of restanoe in the orowded diatrists of the olty to tomah pople how to liwe assording to oomention and cohedule,

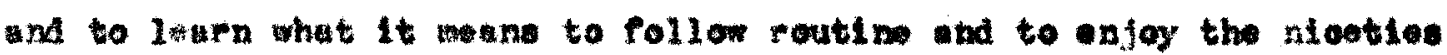
of 11fe. Hany of the pople who attend tha oang have not practioed

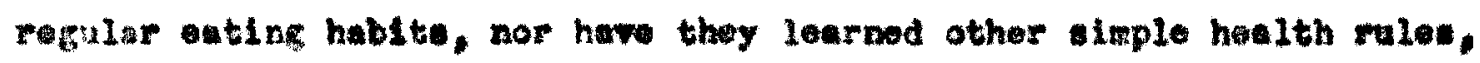
wind the worlaton of apportunity te develop thece praotioes in one of the objeatires. The omp direator and peld oounsolore are aware of theae ins, but gon-ly roviow of them is not oonduoted for the informtion of rolunteser oounedlor.

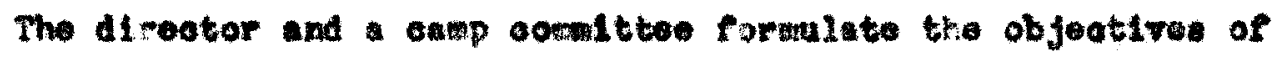
Shlo plamingo. They are stuted by the alreotor as: to derolop

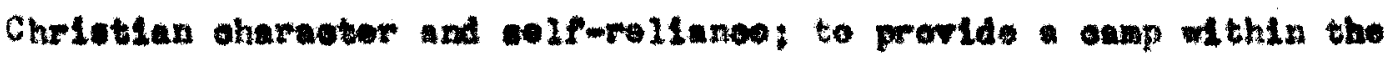
wane of an sterage boy, whore through program of outdoor cotivities, the w1I develop hle bedy: to toagh the youth the rundementale of coatal. afuetwont" to develep his mind through inetration in actiftion suoh as oraft, nature, ot ovtera, and through groster undoratending and appreatation of Cod. The souncelori and oampere de not contribute to the formulation of these objeotiven, but thoy way be ohanged by the Boartis of the Y.u.G.A. The Almootor reported that they wore probably eot up in 1037, whioh tim program orkansad.

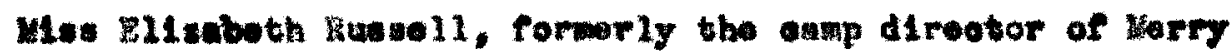
Ledges, wh the boye' workor at Felley Commity House, and the 
oounselors, formulated the objectives of this oamp when it was bullt in the spring of 1935. Miss Rus sell says of the objeotives: "There wore always three things I insisted on In my program with the girls. These wore that the experience sould mean a growth experience to the ohild In (1) frotual knowlodge (nature study, songs, oto.), (2) now silis (table sotting, owlming, folk games, oto.), and in social attitudes (oooperation in group living, sharing with others, et cetera). I M lways tried to make our progran one that allowed for as many natural spontanoous experienoes of life in the ocuntry as possible, auch as wedIng knoe-deap in red olay mud after rain, (ono littlo girl talked of her golden slippers), ploking blackborries for ale, oarrying water from the spring, ot oetera." Wie oan sou from thls aketah that a oreative experienoe for the ohild has beon desirod.

The objectives for Camp Shantituok, tatod by the National Organizetion of Orl Boouts of Amerios, are "to develop the girl indiridually, soolally, wtally, loyally, physloally and onotionally, so that she will not only be more onriohed indiridusl, but more intelligently partiolpating oitizen in the demoaratio social order." Theso objeotivea are reviewod ench your by the otaff. To those have beon addad, by the direotor wh the holp of the staff at pre-oamp training, desire "to oontribute to the developent of onch oamper's wontal growth, health habits, and omotional adjustnent, through providing an opportunlty for practioing voluntary assooiation and oopperation with group and its leaders, through new and progressive experienoes and skille, through stinulating an appraointion of samp and the Oirl Soout 1deals, and through oreative abllities and the ability to ake oholos," Hore the 
ooundelers and direotor huve expremed mons of carrylng out the national objestres, but the eampere have no prt in dsolding whet the lattor chall be.

The objeotives of Camp Chelan are expresed minly by the direotor, whic the otoff moes rovialono evory yoar. The ldeas of the oapare and

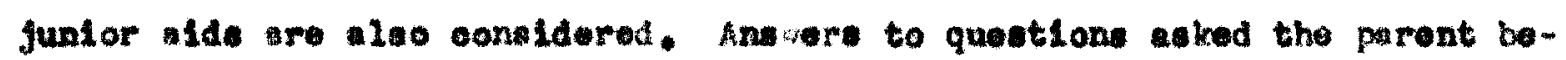
fore the ohild some to anmp reveal what the pareat whes the ohild to gain stom oasp. A Corm ued by Cholen ask the partent to ohook the wost

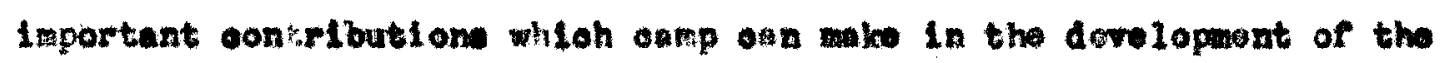
ohi1d. Personal interviewa are alse onduoted between the direotor and the parents. The objectiva whloh have ragulted are: Cun, abelal ad-

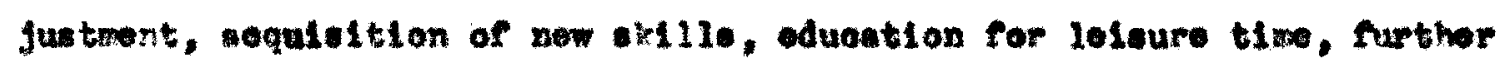
aprreasation of becuty in nature, walo, the arte and worship, and improvement in health. progran whioh is not too abromous is dofinlto aiw of the direstor of Chelan.

The direator of the Camp for colered Girls eet up ite objeotives

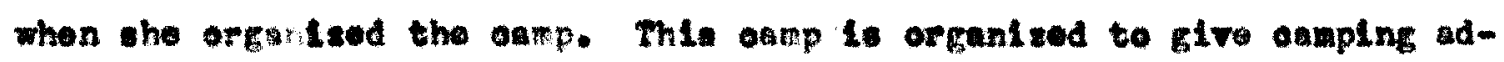
vantegea to an underpeiriloged group. that they may have raoution and loarn more about muture. An attempt ia made to improve the hoalth of the oumpre, and to let them enjoy the exporlenos of Ilfe in the oountry and many hours apent out-of-doors. These a ino have not been reried 1ately, noe did the oawpers have part in formine thos. The same objeotive of oltisenahip training and charactar buliding eot up by the National Organleation of Boy sooute ro used Dan Beard, and adjated to 1 t the loonl program. Here ugela there is no indiontion that the adepera or coundalore have any part in the formation of the objectives. 
The gigeotive set up by the direotor of the Volunteers camp are "to Improve the ohildren's health, and to give now outlook to those shildren tho have had a bad home emironment." It is prinarliy a oump for undernouriahed and underprivileged ohlidren.

The aim of camp Cordon, as atated by the direotor from the objoctives of the Watlonal Organization of King's Daughters and Sons, is the developenent of the ohlldren phasesily, mentally, soofaily, and spiritualify the epiritual derelopent reoeives the greatest enphasis. This is explained by the direotor to the ohildren thas "Ilave fun by 1iving Christian 1ifo--take this thought from omp, itr it oach day, then cowe back to oamp and ronew your sellowahlp and spirlt."

Nount Heroy was originally establiahed as a vation home for working glrls who could pay only smoll fee. No other objeotives heve been formulated lnoe then. Jennie Caselday Reat Cottuge was also ostabliched for businese gir Is and womer with a rery linited alary, and thie polloy has been followed throughout the years also.

Bernard Hason in Gemplng and Eduoation suminily oritiolzee the passive regard for objectives hold by oamp direotors. He saya:

A definite oonseption of objeotives has beon laoking too often hore and thore in the ompine liold. This is perhape more or less true of the directer of all types of camps, bat seons to epply partioularly to the ahort-tern or organisation ompa whes direotors often operate largely booase it is traditional that thelr type of organisation should ran o omp. Then pressed for an objeotive, they state the year around objeotire of the organisation. Spoelfiesily and in detall just what it is that the camp prejest is expeoted to acoogpifish and ontribute has not been adequately analysed. 31 )

31. Uas on, Bernard, Capplng and Bduestion, p, 103. 
PROORAM PLANIING

In planning the progran the question ggain ar aes as to who ahould take part in the proodure. The older mothod, whioh is ot111 uaed by a number of canps, is to have a set program p anned by the director in the form of a regimented schedule before th ohildren get to oamp. A moro progressive mathod is for the oamp grour as a wholo, inoluding dirootor, tafe, and campors, to plan the prolram aooording to need and destres, either a few days before oamp open or during the canp aeson, the group fools the need. This prooers resulta in a aap of the campre rather than for the oampers. So iamy of the lolaure tia sotivities in whioh one partioipates during the irban life of today are handed dow or fiven to the indiridual by others. Consequently, the individual seldon hae the privilege of vital, notire partialpation. It is ohallexging irvitation to omping organization o fill this gap

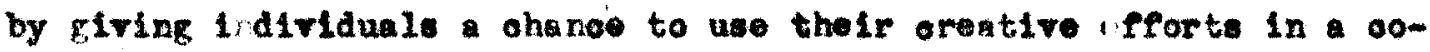
operative planning of the omp program. If suoh a prioess, eapeotally lao'ing in the Louleville area, were follawed by moro oampo, camplng experiences would mean more to the Indiriduale partic pating. This would require very careful aelection of" oouneslors with anowledge of the group prooedure, certatn skilla, ani an underatanding of need to be eflled by the oamp, in order that oampers desires could be gulded and molded into a worth whlle program. The main fallacy of the method by which the direotor plans the progran for the oampers lies In the fot that the adult is aylng what the young poople want, and oftentimo: the result is not what the boyo and girls desiro. This does 
not wan that the young poplo should oondut and adm nister the oum Wthout the fuldenoe of etuff. but too often they aro rot given the opportunity to help plan what is basicelly and prirarli:" set up for them. If the louleville onpe did temet to give tio onpora a part in the plennine of proper. polloy whioh ia rallowel by only a fow

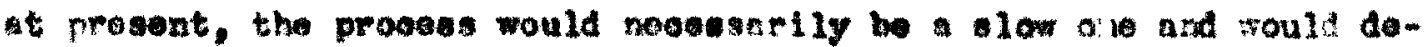
Telop only rradualiy over porled of timo, for auoh , grooess la con-

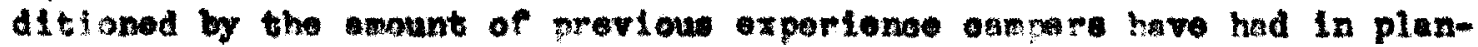

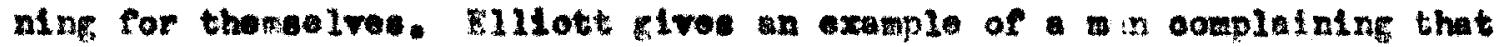
suoh domocraoy did not work in sumber asmps:

Ho Lliustrated his polat by anying that in aortaln conferonos, where there had boon no elfud reotion, thoy told the delegates that they oould rui the oamp. "Then," he sald, "these young poplo aboll thed all rogulatione as to hours, emahod up the funlture and equl peent, and turned the whole onp into ionfusion." Whet the diroetors had lone we to ask a goup of boy end firle who had no oxverienoe in rumline their

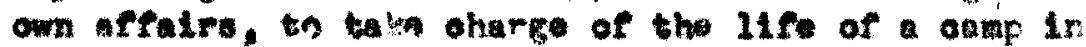
- trange oltuaition away frow the ordinary oontrole. The reault was the only reoult to be expeo ved under the olroustanose-disectrous anaroly. In suoh aup the rotennble readure would have bren flret, to the the boy and firle an opportunity so boowo adjusted to the 11 the of the onmp under the sort of oontrol frow sdal to to whioh they had been cooutened; and then to have outmblished lonoeratio pr saecure In the elmplor cepeate of osmp 1ifo. ha tridtion was

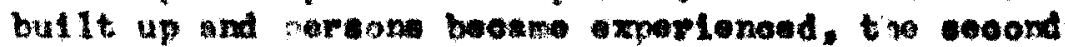
your would have rade posalble core donoorasy. By the

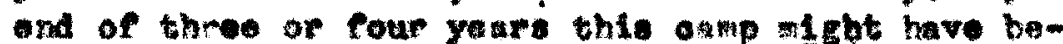
oome oompletely elf-direoting eamp. 32 )

Wont anpe no longer require the ompers to partialpate in oortin activities. but fow have cotually planned the program nocording to tho

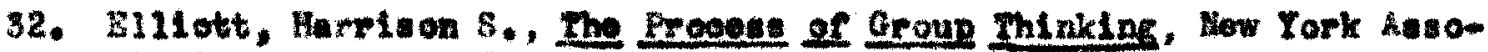
ofution Prase, 1932, $\mathrm{pP} * 12-18$. 
oampers' wishes, Often the program is so full that the campers do not have a chanoe to add oortain intereste whioh they mi ht have, as there is no tim for them in the progran. It is just as himful to have a program orowled with too many activities, as to have one with too few. To what extent the planning of the program oan be le:t to the oampors depends on their age as well as other pointe disousend previously. However, in onse of younger group of eampers, sugg stions and limitations on be giren by the oounselor beforehand, lea" ing the greater part of the planning to the ompers. This is a gradial prooeas requirIne group planning at we as oompetent leaderahip. Spontanoous suggestione of camper croups often oosur under suoh prolrame.

The planining of the oump program hould be a tooperative experionoe of direotors, counselors, and esmpers. 33 ) The interesto of oampers should oontribute to the program and thelr actual partiolpetion in planning should be sooured in proportion to their agos a d experience. Such devices as interest findere, camp oounolls, and planning groupe are useful in this rospoot, but the mogt important faotors ire the understandIng and ability of oounselor and the establishnent of construotive oamper-aounselor relationships.34)

The former oump ilfootor of Merry ledges eet the pettern used by the oamp in planning the program, she says: "The program for the perinds of organlaed carp in the aummer was usually planned by the firlo' and boye' workers thesley House, in conferenoe wh their counselors,

33. DLmooh, H. F. Charao'cer Edueation In The Summor Camp, Honograph III, P. 9.

34. See Oeborne, Ernest, Campinf and Guidanoe, How York Alsoolation Proas, pp. 186 and $16 \overline{\mathrm{I}}$. 
though 14 we lert quite lexiblo in ordar to absorb augeation of tho eroup efter they arrivod ot oamp." The gereral direotor of the

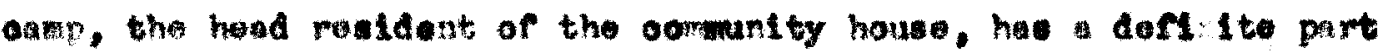
In the mrogram planning. The gonaril skeleton of tho program is at up by the omuntera and the dirmotor before ommo opona, and is read

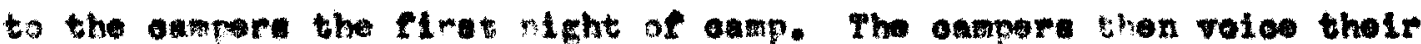
oholes as whet thoy would like to do, and oorreaponding plank are Inoorporated Into the mograw. The program is arranged for a wok in

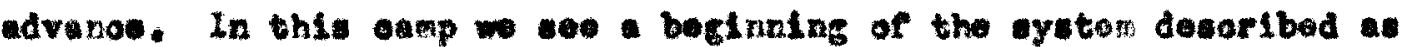
destrable in the riret of thle veotion.

Comp shantituok tiso has developed a daelrable typo of program planning, whioh to don by unita. The protran poselbilitios are prosented to the sampers by the ooungelore te unt mooting weunily held dally. The lendor 1laton to the exprosalon of the oarrere' interests and asts up the profram with the guidunat of the counselors. The genoral protare planing is done in the method dosorfbed the norning after

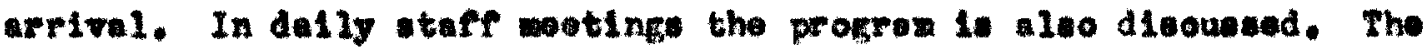
questions abked on the blank whtoh the anper is asked to fl11 out beCore ooming to enmp are used to disocver the oampre' Intereste. At Camp cholan the annors oheok an "Interast shoet" the firat nifht of amp. These oheots are uled by tho otafe to arrange the dally

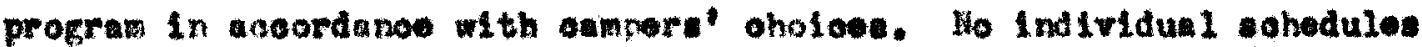
are rade but the young poople ettend the 1sterest groupe whioh they

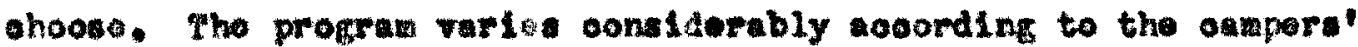

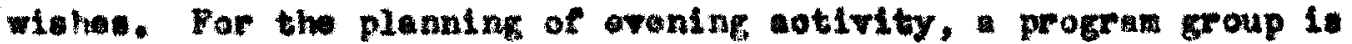
forwed at eamp, In whioh sach oubin is liked on ropresentative. 
The progran dirootor and other ocamselom noeded, suoh an the mals

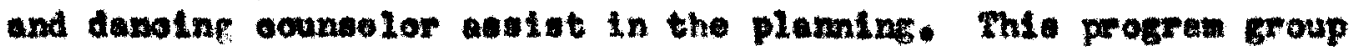

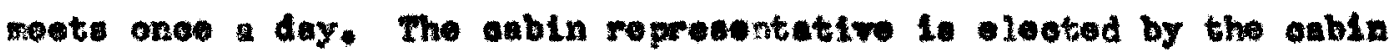
group the elret night of own.

At Dnn Beard the paseing of soout tente is large part of tho program. Feligion inotruotion is earried on by the raligiate director,

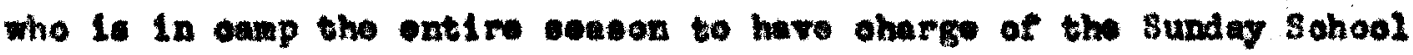
and provohing serviooe. The athletlo ganes are plannod by the reoroation direotor. The oump fire progran and other "extramourrioular" eotivitios are planned of the progrem direetor wh the help of a

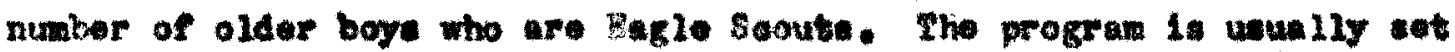
up a dey of two In advanoe, and aooonding to the dirootor oonforw to what the boye wnt. Hawever, inoe it san be seen that muah of the progras is already wet up befors oapp opons, wuch the pasalng of

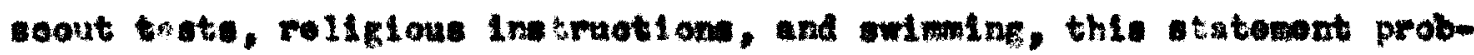
ably refere to the oholos of games, and the type of ommp-rire progran

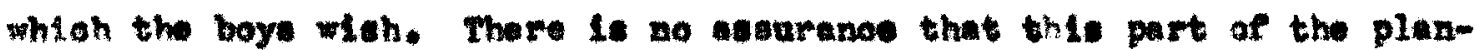
ning 1. particlpatod in by the eampar: as whole. The direotor of Dan Benrd states, "In ceouting. rooreation is inoldontal to getting the boy trained (provanbly te ourry out the objeotiven of soouting) but the boy wut hero reareation pariod as wil."

The stafe and dirootor of the camp for colored oirle determine the polloy of the onat, while mogram comalttec made up of a group of oampore and oounalore moete dally. One of the counelore who neloats the rifls for the program oomitteo attempt to saleot a diforont on aach day. A chatraan is allocted by the group. In olub motinge 
held at loot onoe or twlos a wok, the oounselers talk with the girls and ondewor to dlacover jugt whst thoy mat as oamp. An attempt is made throughout the canp promran to get the ohildren to make their own ohojice and to dovelop Inttlative. In the omp-eire progran the Aret

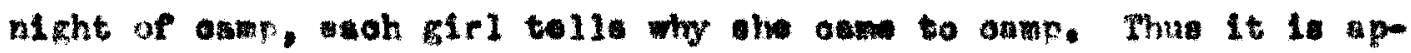
parent that the aumpara" Intereate determine the bype of program to

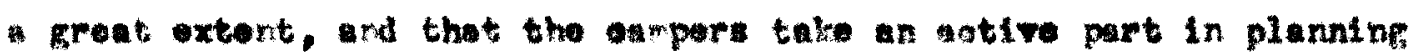
the progran.

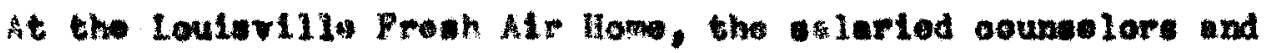
tho dirsetur work out a tentative progran three daye before the oponIng of ondp, and oontinue the program planing al daly atafe motinge. The counselore oonault the ohlldren on the oholoe of danose, songe, bunte. at etere, but noither the ohilaron nor the rolunteer counselore here ay furthor part in planning the program.

In the pat the diroctors of the Y.M.C.A. oeap have planned the prokram for ohio lioningo, but next season the direotor Intends to plan the mogram with the counealore previous to the opening of axp. He 1so plane to oundust oouna lormoumper rooting ovory day to talk ovor progran ohanges. At this omp tha progran is planned for tho boye before thoy ocme to oamp, and Prom thic they way ohoowe tho ootivities In whioh they wiah to partlolpte. An nttompt to lisoorer the baye"

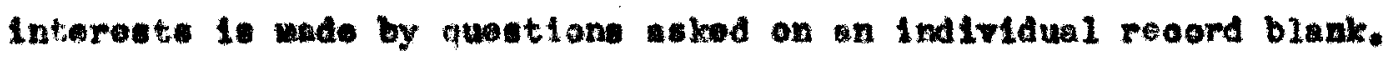
The oumer program for Covered Bridge Revervation is planned befor oamp by the direotor. The asunt of teotmpasine decired, the

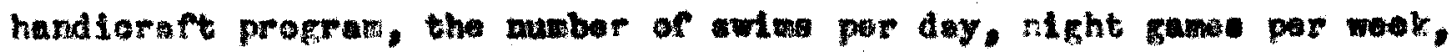
onpp flros, number of hikes, and the type of sposial iotititios are 
deolded by the direotor and these evente aro dietributed tiroughout the aven day period. The oomptitive afternoon owent are dealded

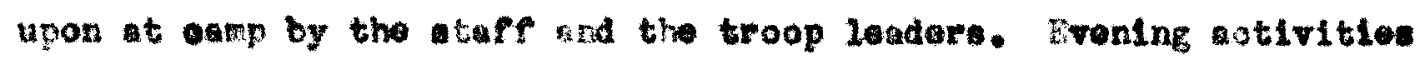
are worked out in detall. The onpere have no part in the planning of these notivities.

The progran for camp Gordon 10 planned before amp open by the diroctor and two asistante. In planning the program tho dirootor oon-

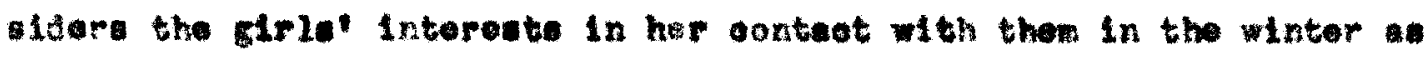
the youn people's Alruotor of the KIng"s Daughtere and Bope. Fula

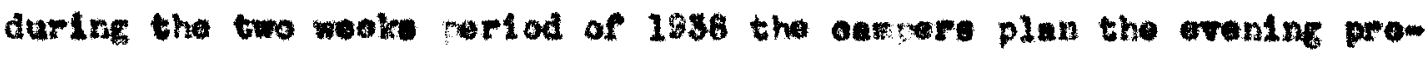
aran with the help of the atiff.

There is no program piantng done Jomnte Gassidey hoat cattage, except that the buelnose firls plan what thay wat to do during the duy.

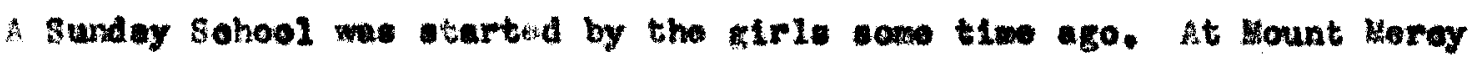
the rereational as rootor does 11 the planninf of the prograt which is mude, such av Eling argetion to the group for overing ontertalanent

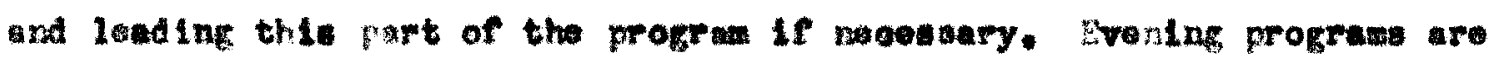

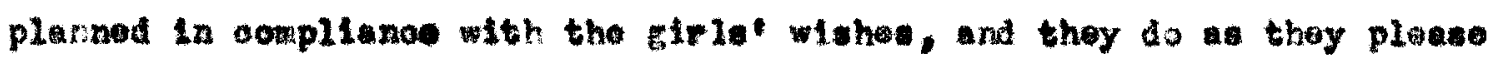
during the day. the Voluntoora' Camp tho progen is plarino by the Alrootore round the limted sotivitio araliable.

\section{ACTIVITI:8}

\section{Dor.ty gohedulee}

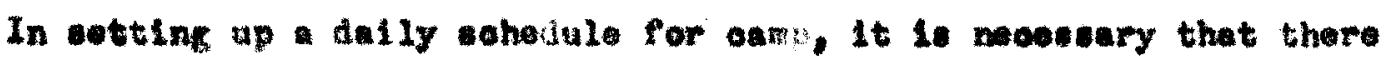

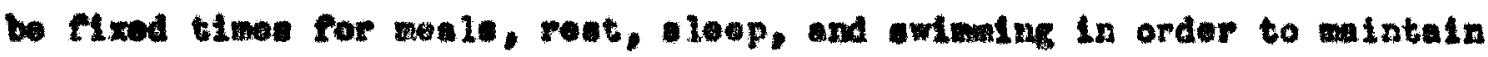


surflolent health atandarde. Alde from this, there is no spoolal neod for a oet program of cotivition, for often 1t is by cuoh o wothod that the onmp beooman too atranuou for the oumpars, and too regimented. Thif does not mon that a rariety of wil ohoeen ootifities should not be offered, sa this is vory important, but the oampers ahould hove shoto of ativities. Bernard lacon, In hil otudy of sampors' prefor-

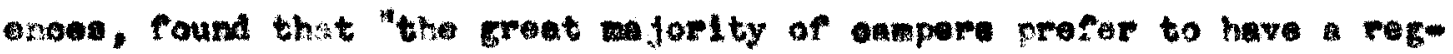
ular sohedule of theif time in oum, but want ows ohotoe we to the activities thet oomprise it (partioulariy omphawied by the boyo). It is the cantort of the whedule ath whioh they are oonearnod. About twenty-two porownt fevered 211 or purt of the any entirely ree rrom companeory cativites."36)

Oemping wothode have ohanged from the old ldea of haviag onoh individus follow pareonal mohedule of Instruotion in activitios, whloh the wa foroed of at lenet axported to ettund at ctated hours, to an opposite theory held by some oamp euthoritles that the aotiritles ohould not planwed scoording to sohodule.

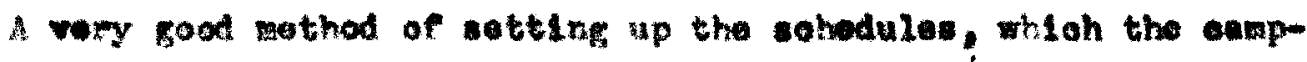
are have rocomonded, is that of sorten of interagt groups oleated and ohoeen by the oampare. If the cotivity in made Intareating onough the oampre w11 soon went to twke 1t, and If the irutruation is good and exjoymbio to thom, they will continu to be interested. Ono excoption to this theory is owiming, whloh thould be raquired with fow exeeption, as this actiflty is an eanential ski11 and oamp is one of

38. Kason, Barmard, op. o1t., p. 166. 
the best, and often the only plaos, the ohild hes the opportunity of Iearnine how to owin, Most eampere are lready interested in owimming unless laok of knowledge, or ablity, or porhape wow provious

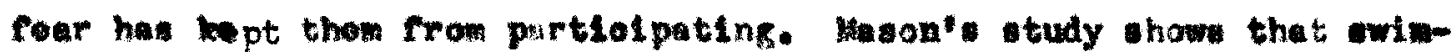
wing to the most popular of all boy and girl cotivities.

Athough sow organisution and sohodule is osential, cospulsory

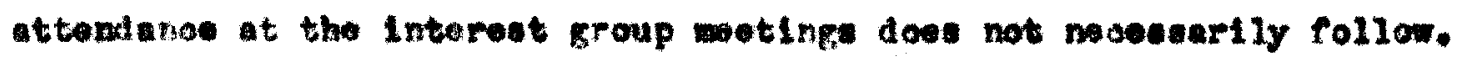
Derintto poride in the sehodulo when the oampar om have leluure tin

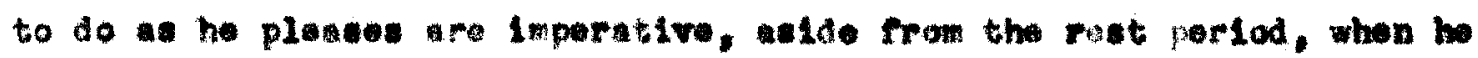
should be required to 110 on his bunk. 被ether this partad should be one of abeolute quitet and rest, of whether the oumper should be allamed to write, read or telk in oontroveralai. In the wajority of oanpw where full day of rather strenuou adtribles is acheduled, an hour af reet to undoubtedly noedod in order to maintein the houlth of the majority of onmpers. The Importanoe and akount of seep nocessary hus

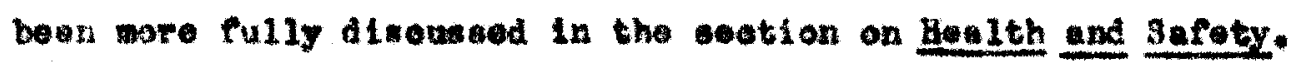

The ativities of the Yointeore' Camp are rory lialted, partially

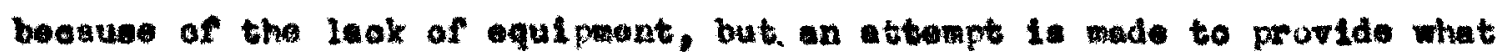
the ohildra ack for in tho way of gamos. The ootivitios, basod primar11y on arailable equipment woh owinge, trapone, oroquet, toye,

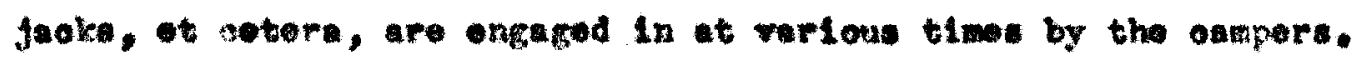
A motar boht and two row boste are aeed, bat the ohlidren sre not perm alted to go out in then alono. Singing is a part of Blblo sohool. Som hiklng and unplenned attivitien auch we bleokberry ploklng are partiolpoted In. Regular houra of aleop, propor diet and roliglou 
training are the In wrte of the prograx.

Ho planned program ie adhered to at Hount Horoy. The buninens girlo who come to oamp wainly to rest, have a oholec of notivities

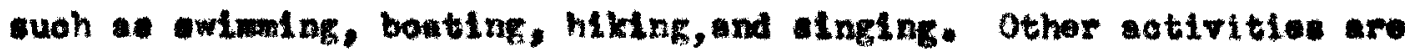
also based upon avalimble equi pment auoh as tennis, base-ball, ohook-

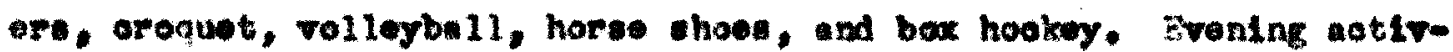
Itles are unully orgenteod nooording to the firle' deatres, but are vory Impromptu, ouch as gathering around tho plano for alnging, danotng, or oard playing. Sowe now thinge were introduood by the recreational direotor last weason woh we rolk and round danolng, wow group ganos, and now songe. Thle attompt to five the onspors wholesone ativitien led by roarention alrootor buy prowe rery benefleial if developed more rully in the future. Thoes activitien were not foraed upon tho group, but added to the interates hown by them.

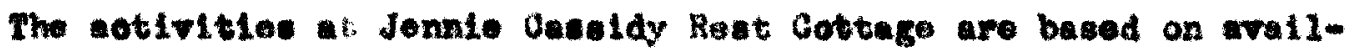
ablo equipast rather than plenned program. These conulet of oroquet, tannis, cames, radio, and pisso. The girle way hike to a noarby quarey to owin if thoy wisk.

Gamp Gordon has achodule plenned for tho oumpors before camp opone. Fag rosing is a formal oeremony partiolpotod in by all, as are the devotional perlod in the morning and the tenohing of the order of Tha IIng's Daunhera. The oampere have oholoe of other actiritiea

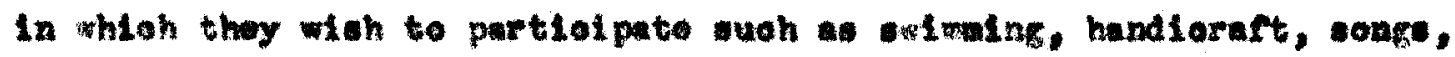
dramation, and sowe equipont gamov. During reat hour the onmpere are required to 110 on their bode, but they may read or write. The oventng sotivities comblet of oush program a treasure hunt, barn danoe, 
oharadea, sapp flros, 3unday night suppor, hobo party, and a banquet the lant night of aamp.

The dally sohedule of Covered Bridge Reservation, planned by the Alreoter before anp boglas, raveale e rery extencive list of aotivities, no onforoment of hioh is made, cooording to the direotor, The boys may heve on moh lelsure time ac they choone ond are not oompelled to ontor into my activiby. At revellio the otefe seloote the bugler and onn or two boye from the honer cheltre cash worning to ralee the riag wh110 211 the sooute stand at attention. The aetivities inoluded under handloraft ere: boudwals, the makinf, of totom-pales, oanoe paddles, oumping and arohery oguipment, metal work, wood oarvinf, and leather work.

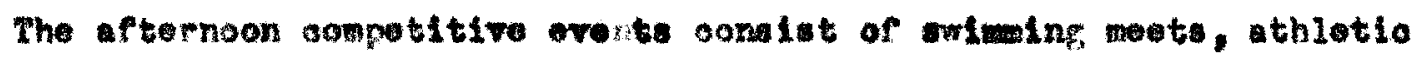
weata, and seout oraft weots. There ere neture hikes, early morning bird hikes, wh owernight hikes onoe week, which everyone must take.

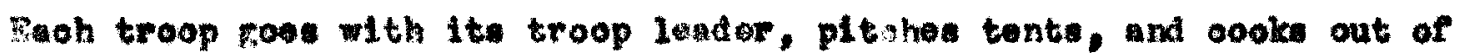
doors. Mbout twi a wook in the ovening night gavos suoh es "Capture the In" and "Garnane In The Dark" are played on the "Plate" or open ections of oxmp.

The soout prograt conelate pelmurliy of ceout oraft and wood lore,

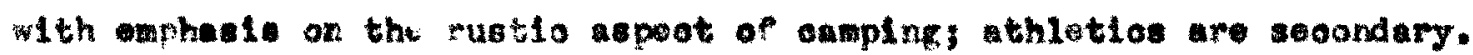
Aooording to the direotor, athletion are ciren as opportund ty to per-

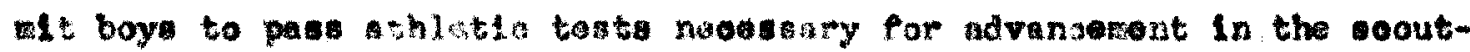
Ing, rank. The propran the toralop alf-reliense in the boya. Onge eash porlod at Covarad Bridge Reservation there are deflnite

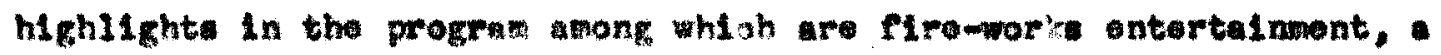
sham bettle and flour Mght on July 4, "Goldmuh." trensure mant and 
Ind Lan pagent, et oetera. Canp fire programa or "oounell Pre ring" inolude evente planned by the boys, auoh as songe, bunts and tories. The wor-front progran inoludss swiwing, boating, oanoeing, water polo and othar ganes, water carnivale, diving, rooing, flahing, log rolling, and oano tilting. Rirlory and oapp-oraft aro other ativ2t108. The merit badge ayoten, dinoused later in the sootion on Lotivation, is axtensiveiy promotad. Wny of the notivities montioned and the manner in whioh they are onduated aro olosely roluted to the morit badgo program.

The dally cohedule of onlo Plontrigo is arrenged by the direotor, as is the spolal cotivitie list whioh is used as guide in the plannine of such aotivitlas. The boys are not foreod to abtend any activity, but as has bea noted before, they beve no part in the planning of the aotivitios. At overy hobby poriod ahook is made to ses if all the boys nre buty. Those who are not engaged are questioned by the acunselor in an affort to diecover the oause of suoh inaotivity and to arouse the an: ver Intereat in cowe phane of the prokran. If the boy beomea a probler by never taking part in ary aotivity he is roferrod to the al-

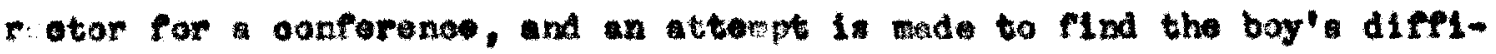
oulty and to sdust him to the one progrem. At Ohio Homingo emphas is hav ben plaoed on thlet is, the program for whoh inelude volleyba11, baseba11, foatba11, owh Ing, wrohery, badminton, ping-pong, hormeahoes, and othor thlotio gamen. Cumprire prograns are of two types, the Indisn oumpfire based on Indlan Ior, custom, ot oetera, and the camperire for "fun," ahloh lnolude congs, atorles, and ctunte given by the laddere and the boys. Mmong poolal aotivities during 


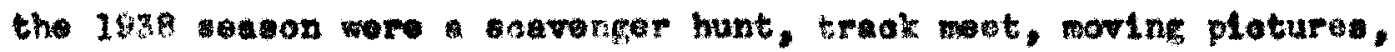
a wher roset (by untes), and banquet the last night of oamp. A rery good Interest helet, tos lengting to be inoludad here, is to be oholked by the boye in 1935 , In n attent to learn their Inturuste before oomIng to on p.

The dally sohedule of the Louleville Prosh Ar Home lnoludes

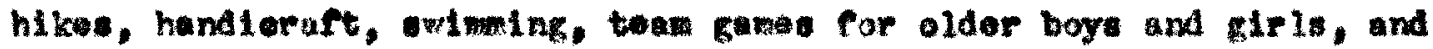
airole gares for youngar ahlidran. On seturday the propram in oharged sowewht. The morning is civen gror to swiming, and tho afternoon prom Erav onsiste of troanure hunt nd plonto supper. As the froup is

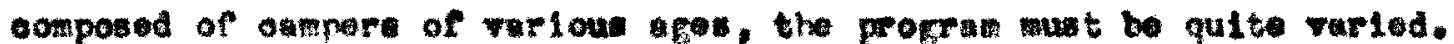

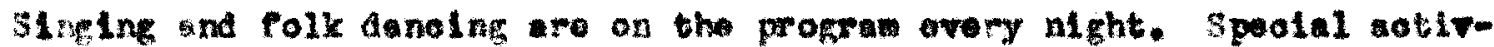
Ithos Lnoluded last aneon ore:

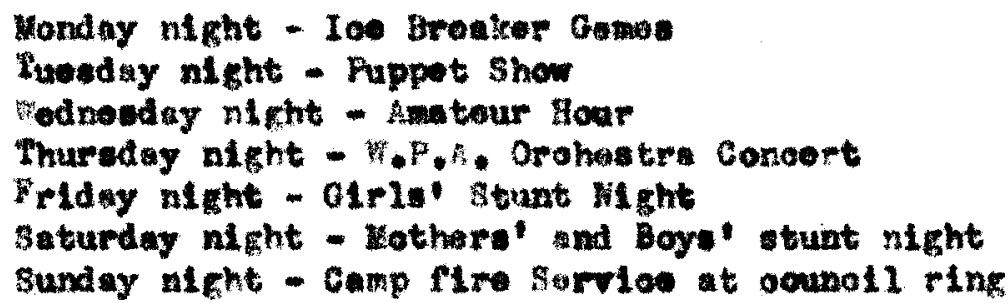

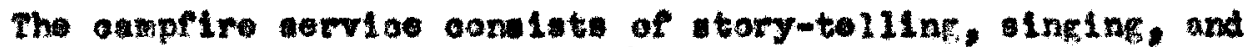
stunts or anoadotes, onding with friendehtp alrolo when tep aro aung.

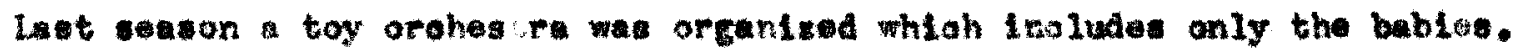
The tane game are volloy ball, of ball, ring tanmis, horeo soos, call ball, and other croup pawes. The handloraft progran rarlea acoording to the type of group and the werlals avaliable. The handaraft is partioIpated In inly by the rirle, partially beouse of the laok of waterlale to 1nterest tho boys. Splater paintine, makln of oostumas and propertien for stunt night, pooketbook made of tapastry ean plos, and 
plaques of plater of frarls molded and dacipned in frames mads up the largast part of the handiareft. Lelsure tino is offerad to the froe

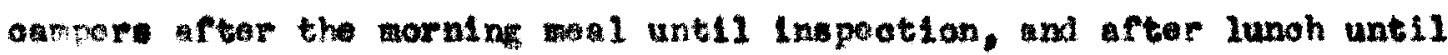
rost hour.

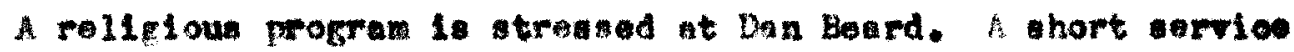
28 held on Sundey fternoon, whioh ovyono attants. Tho passing of

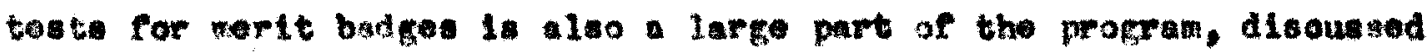
Inter in the seation on gitivation. The rooreation program oonsisto of aotive games suoh an basobet l, hardball, tonal, bedinton, horee-

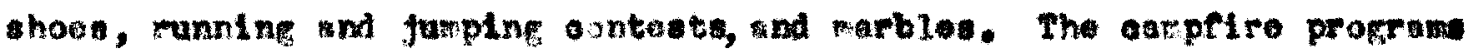

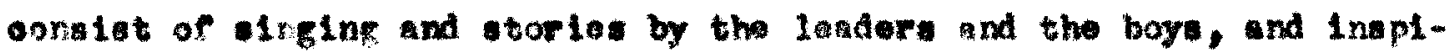
cational tal by member of the etaff. The parants are livited to runing and jumping oonteots and py oxhbition. Sone lelsuro tim is afforded after dinnar, when thero are no planned cotivitias.

At the Camp for colored olris a great deal of ties is froe and wuoh 10 deroted to osmp dutios. Those spelal duties of oarpers in

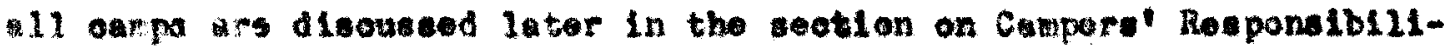
t10e. The handieraft program inoludes pointing, soare dyIng, embroldory, and awing. "uaring and baketry ware Inoluded the firat two yoars, but wre not ontinud last wason because of laok of n terlals. Story

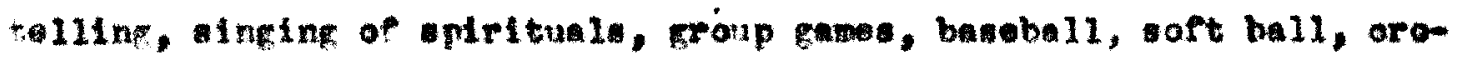
guet, tonnis, horaeshoe pltohing, ahookers, hikint, tap, folk and soClal denofne, and some nature otudy make up the ajority of astivities offorod. The ampelire proprama planned and partiolpated in by the

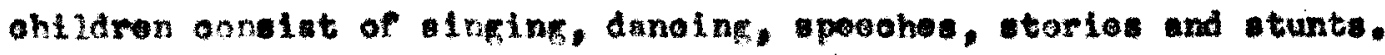

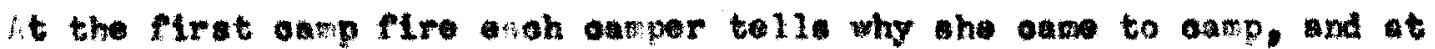


the lost oamp firo onoh amper tolls what benofits sho thinice she has

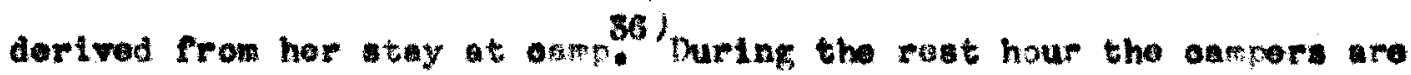
not llowed to rad or writa, as mule time for thin lo provided elaewhere in the vohedule.

whe dally ohodule at Camp chelan is dorlved frow the intareat shets, courding to the cotivition ohowen by the oapors. The ativiLes on the lnterest shoot aro olased nooording to water gporta, inoluding, owatng, bouting. 11fe saving, onooing and Paling; land sporte, loluding horaq-book riding, arohory, bodminton, and hiking: handieraft, oontaining puppetry, baketry, oketohing, olay modeling. nature orafte and mol, logther and wod oraft: the arts, ombraolng dranatios, lictohing, potry, danoing and thythm band. The interest

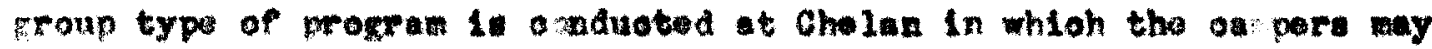
ohoose from the ativitios offored in osoh intarost roup. This nind

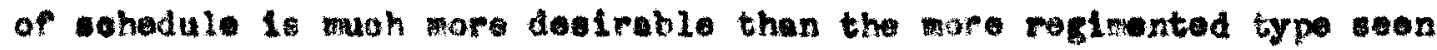
In sowe of the other oumps. Overnight hikes are elininsted frow the program bequas of the temperature, but day hikes are taken, and tripe to nearby foreat in bus are insluded as a soolal troat.

Prow the explanation fiven in the seotion on Progran ranning rogardine the typo of Mlanning oarried out at Canp shantituok, the plexibl11ty of the unit plan io shomn.

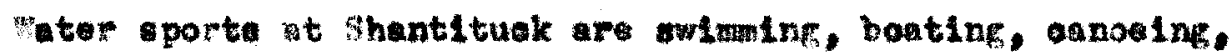
life aring, divis, fishlng, and wadine. Crafts inolude oketohing. modellinf, whitilng and weavine, wood ourling, and blook printiug.

30. Sev cotion on "Progntw Plannine" and "Bvaluation" for further disouselon. 
Early aorning and all day explorgtion and overnlght hikes are oonduoted lonf wh trall oookery and quasta." Hoturo tudy, photography, country danoine, dromblos, singln, onpelres, arohery, badeinton, and other group ganes maine up the list of activities.

At Werry lodges the progran is quito flexible and large amount of free timo ie given. Tho ohtlaten aro not foroed to do umything. whioh probably would rot be neceasary alnoe they ohooe thilr ativities and help to plan the program. The approdate tho typ of program of frod by the formor encp Areotor' duaription. She writee: "Our pro-

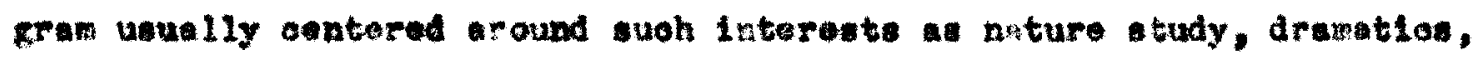

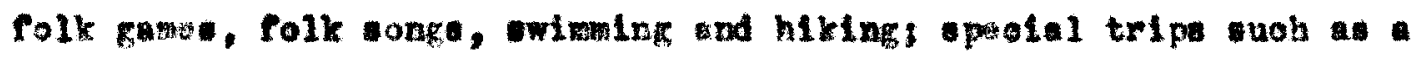
rist to U1s: Mabel Johneton, daughte: of tha author of the Lttle Colonal serles; parties, 1noludinc sons others a Treo party, a movle party ith shodow pi tures, and Nother Goove party. The ohildron ususily

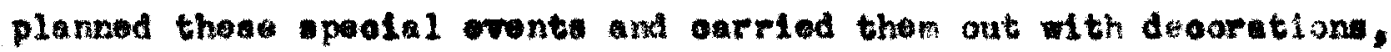

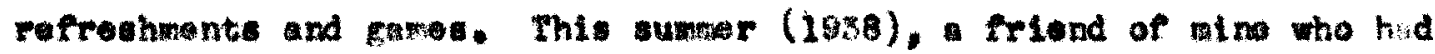
roturned in April from three yoare atay in Shin was wh wo. so onoh day we had Prlendship Hour durlng wh th weard about boys and (ris in other lande, partioularly the orient, On the lest night had arld Frienduhip perty." The sotiritiob atreased at lerry lodges

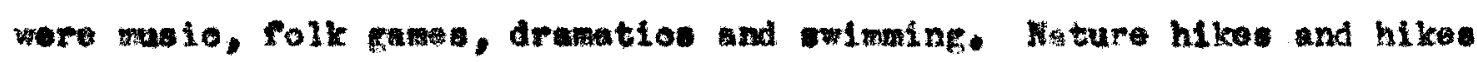

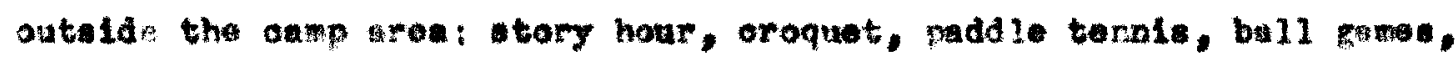

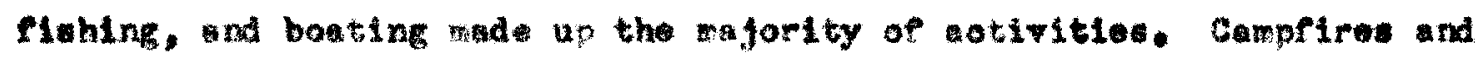

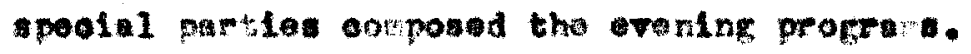

The bas ativitie whioh are offered by pratioally all oumpe me solming, walo (at, labet group singing and owe form of danoing, 
preformbly folk), nature atudy or oakp oraft (both if posible), group games, some kind of areative handoraft, and some form of drasatios.

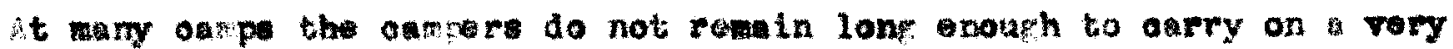

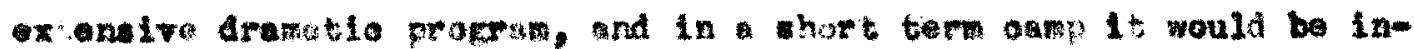

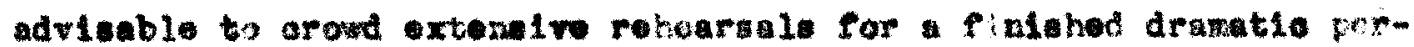

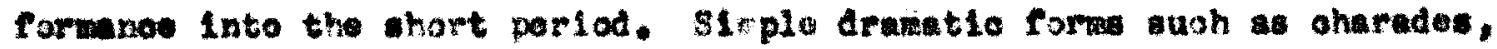
dramatio aklto or pappetry way be enoonraged, in order to develop the ohlidren's oreativanen and givo that an opportu lty for solf-expreasion

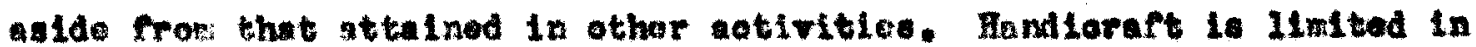
many oampe bogase of the oxponse, but often the bett handioraft is done with imple cquipuent, suoh sa aketoling with oharoon, oley modelling and wodoraft. In oreative handiarart mogr the profocts are lor to the onpore' oholas and Ideas muth pontble.

The out-of-ioors aspet of omplng is of tromondous importanos.

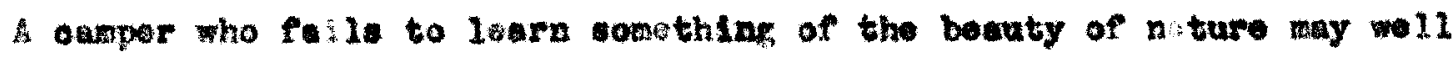
blane the propran. This appredition and onjoyment of the out-or doore nay be brought about in wotivit1es of omp other then nature atudy. asoh as atwing, hot the, woderaft, danaing and othere. Nethod of rasehing

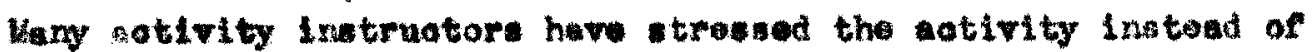

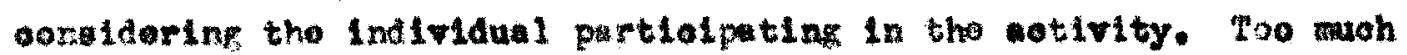
-aphesia has orten beon placed upon the sill whoh the ladiridusl dem velops rother than the oolal valus ho way redelve through group partiom 1 tion ir the aotirity. The cativity fould be ane to an ond,

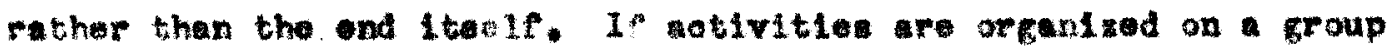
besis, woh as wroup eingins, folk danelng, overnitht or day hiker, 


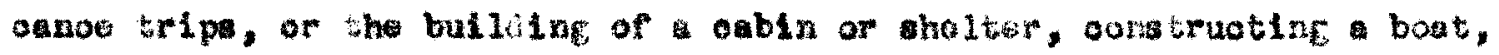
greparing for pageant, play, at otera, more odoperative my of 117-

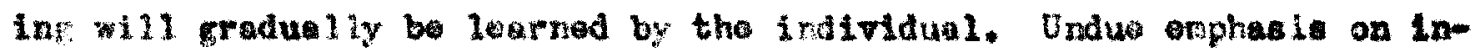

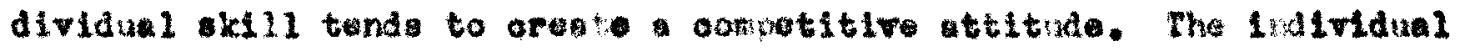
bogine to onre onily for hit own ahievenent, lytage of aharing in the development of this nollowent with the members of the group. Thero

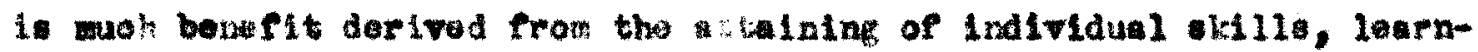
ing how to shis, how to paddie ande, how to carry a tune, arrve a

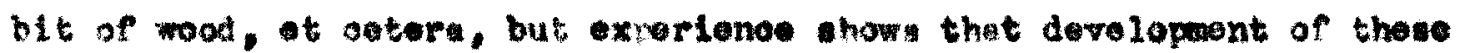
ok111s on be faolittated through froup prooese with additional value ceoured. The oamplire or ovening progr afford ar exoulient oportunity or suoh ooporativo plantine nad pertioipation in aotivition. In

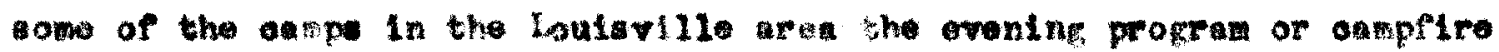
is planned by the oarpers. In othere this purt of the prograw in planved in advano by the direotor or atref, nllowing no opportuntty for dovolop-

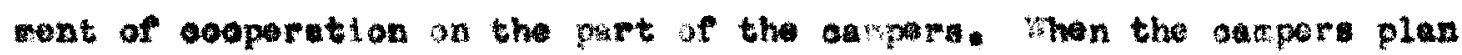
the proprem themelves, wh the help of the oteff, It means muoh wore to thon, for it is thelr progrem, and by having very dosint te part in the planing, thels Imgenulty and Imagington are aroused and their sapsoltied developed. suah method has apoolal value in developinf

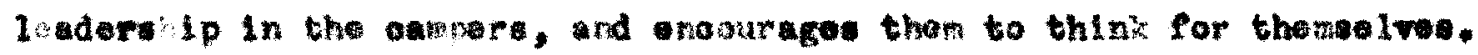
In the sroup rethod of learning, the amper not only latarne the oproot way to hanuar nall, or oaw log, but ho also learns to holp bis notghbor and to roostre help from him, to awit his turn for the tools, and to hare the thrtil of the fintahed product with someono olso.

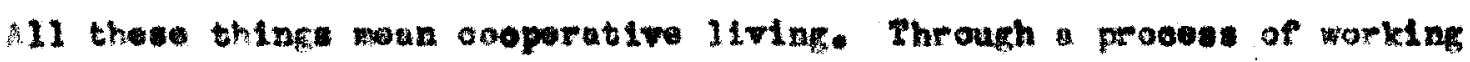




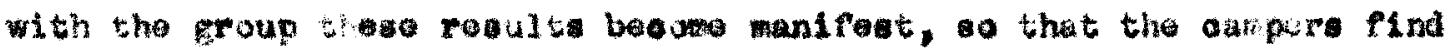

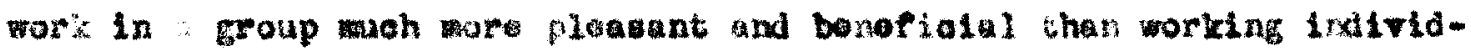
ua 11y.

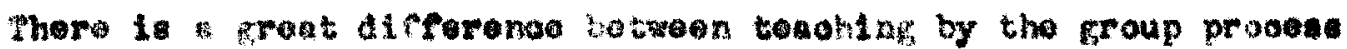

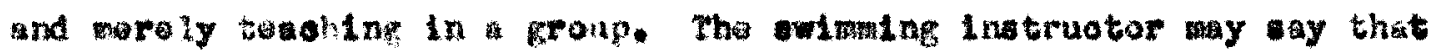
ho is using the roup provese beouse the group of beglnnors are taught

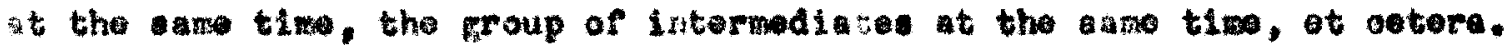
The differen 11ad in the whod. Thoro are muber of ativities thioh anmot bo learned by arooess of charing. For exemple, in tembis,

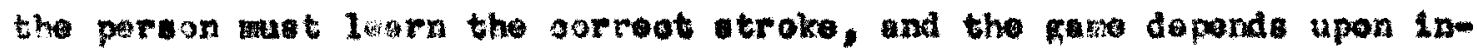

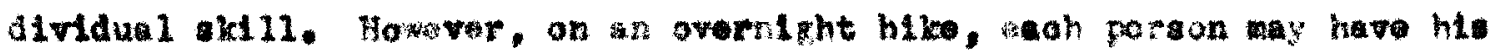
own duty and ak111 to porform in proparing the west. bat the meal in the ond has boon the ragult of ooppraclvo orfort, of working and planning

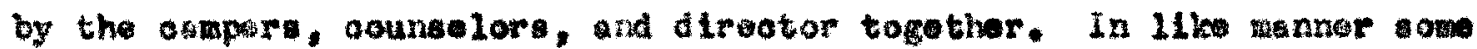
handioraft projoats bey taught by the froup prooss, woh os the palizting of aral or lake soene.

If consideration is iven to what the indiridual wishes to obtain from asup, wo w to that his potentlallties aro, tho dangor of too Fuoh emphasis being platad on the ativity will be losaned. The activ-

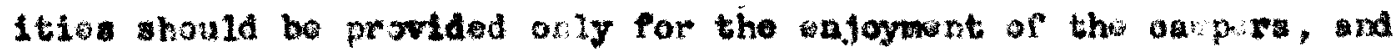

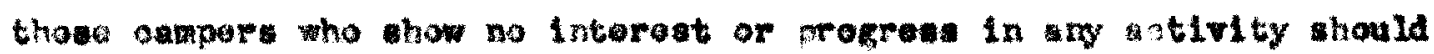
be obaerved by the oounselors in an stoupt to 10arn the reaton. shen

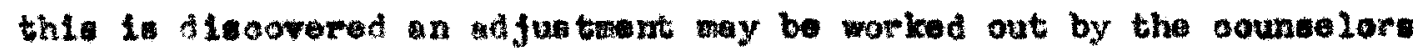
and the somper. Aohlevanont

In judging the exicnt to whioh empers have gainod akdll or 
improvenene in eotivitta, a blak form nay be uod, but the import-

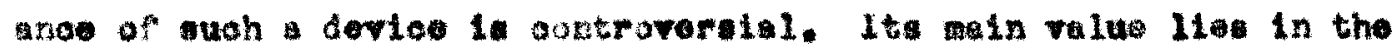
judghent of mother the ommer is the any progress during oamp.

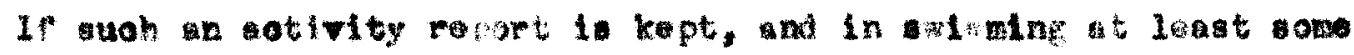

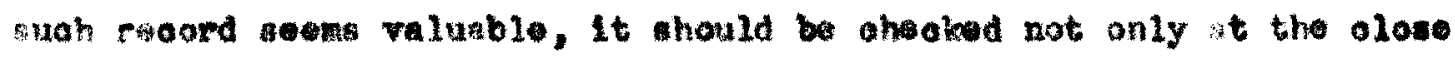
of osup but aloo during the onap agson, wo the the onver who is not maklng progress in any ativity nay be enomurad ond guided. In a very amall oum (of not over ferty oumpre) whon there are a cuffioient number of councelors (one to four onmpers) to watoh the progreas of the individual ogerper for whom they are rasponsble, moh otivity rating

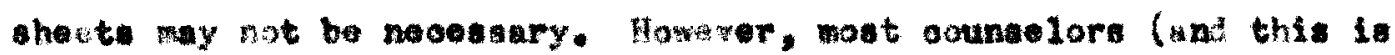
Erue of the samo in the Loulsvilie aren) ars so busy ith the cotir-

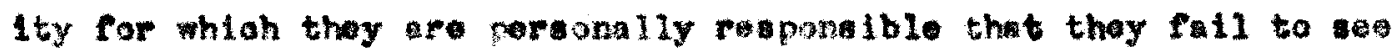
the progrest of the onmer in otwar activities. Sush reoorde are therefore very heipful in onab ing oabln oouneelore to viow the ohild a. whole. The method ueed t Comp Cholan is umasually good. Here onoh notirity sounelor kepe reoord of the interest and propress of the ohtidren who partiolpto in her ativity. This is used by the other counalors to belp that judgo the osmpare for wom thoy are responstelo.

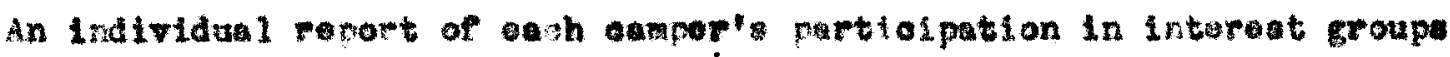
is wade to chelan by the oounedor, who warke the lytarest and progross of ach camper by throe ohooks none, ono, or moh.

The achlovement raoord blank whioh the direotor of Ohio Ploningo

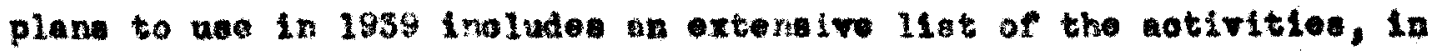
whioh the loderahtp and interent of abours will be rarked coording

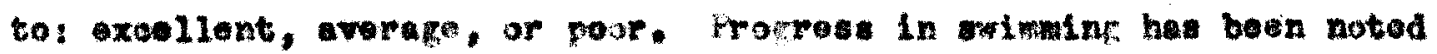


In pot oesons. Fereonal aheraoteritios and behavior wil bo oheoked

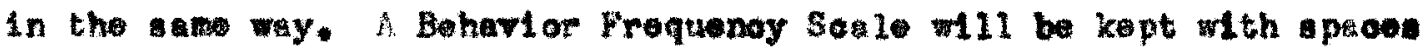
provided for mathe various types of boherior soourring nster, se1don, sometima, often, or always. A paos for analysis and oomenti by various loadore is provided on the baok of the blank. If this form is used by woll trained otaft nombers, it wll probably prove vary help ful in ettaining on urderatend ing of the Individual oampere.

At Camp Shant1tudk doflnt to ctamet is mado to get evoryone to awing. An indireot notivation is used by the lesders to persuado

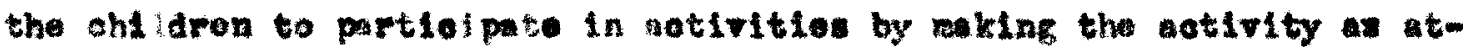
traotive as posible. The oampers" progrose at Shuntltuok ts sheoked as part of onoh ouper' raopd. Progreas in oulming, noture atudy, and tralling is sheoked as part of the rogular coout merit badge progran. Interest and afficioncy in other aotivitio ia noted. In the 1939 season the direator of Camp shantltuok plane to hav carrative style of reourd kept inctesa of the ohooking nystam, with the samo things noted.

The advanaenent reoord bept by Covered Exidge Reservation is very oxterive as It is a roord of the teste pussed ot camp for the awarding sf tadge relutive to the wintor prograw. 37) Wo foord la kept of the

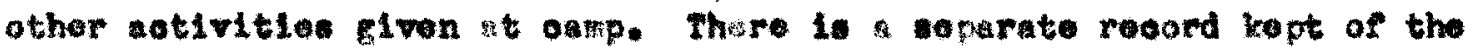

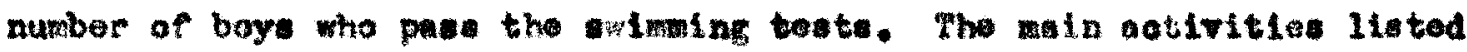

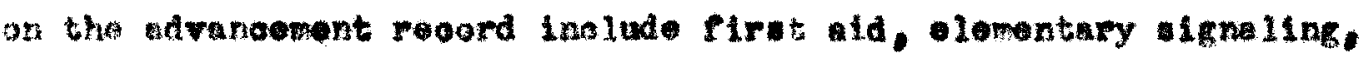
trucking, fire bulldint, oooking, thelft, abety, Ilving the law and oth, nsture cudy, woping, hiking, nd other coout aotivitios. Also 
at Dan Deand rooord is kept of teots pesed by ompera woriclup for the werit badges.

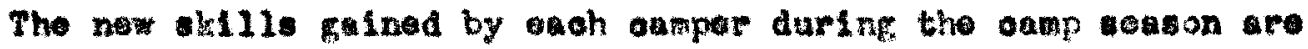
matixod by the scafe of Marry Lodgea as part of the individual tudy of

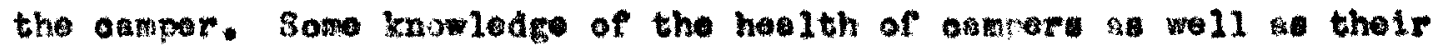
general oooperative otitude is oondlered osontlal. No aotivity

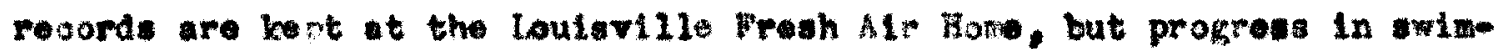
ming is noouraged by awarding sulmore" sards.

At the Canp for Colored olrle, the sounselors noto the progress of the omsera and help the onlldren beome adjuted to nom ltuatiors. Stress is laid on group contsota, and the onlidron rasden the 1 know-

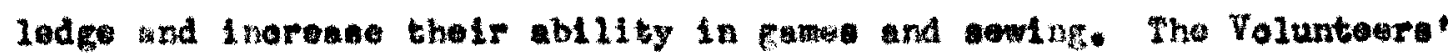

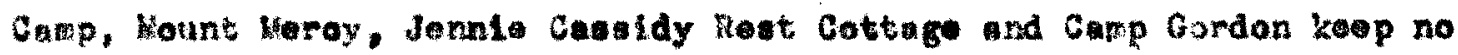
reoorda of notirity pertialpition by the ourpere. Canners" Reponatbil1ties

In wany samp, partloularly in the Loularille aroa, dowpers have

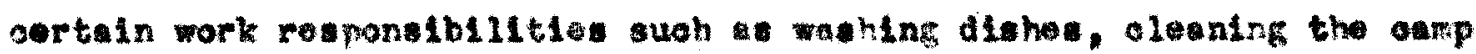

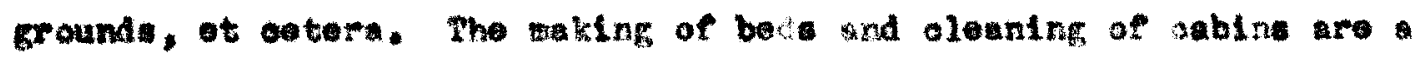
part of the ampera' responaibilities In 11 campe, the ralue of whioh

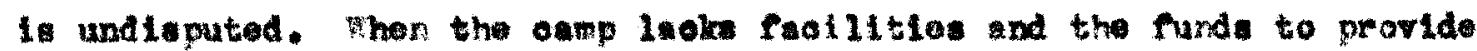
then, as to the fority of the Loulaville oars, oonstruotion as an sotivity might well be provided if the oampra wow a desire for anoh.

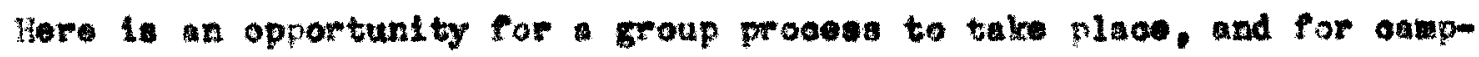
ors to wake their port in the oump nore definite. Loborman dearibea the bonetite of ach prooess by aylns:

The camere rool the oamp is thelrs. Their partioIngtion in 1 to construotion adds furthor to thair 
gense of owners lip. An inoident whioh oocurred toward the end of the firot summer 11lustrates this point well. One of the mothers who risited oamp was disappointed with its orudeness and asked her son whether he didn't miss the better faoilities he had had at the oamp he ttended the provious summar. 'Fol' he ald, 'there are lots of good thing here, and bealdes wo on make this as good as wo want 1t." He then reocunted how he had holped to billd the dam, the baseball diamond and basketball oourt, and told of the plans for the future for a tounis sourt, for real lae, boats, ot ootera.38)

Suoh arogram oould well be ingtituted in the campe of the Louisvillo aras with fust as bonefiolal results. In taking care of their own eatablishment oampers learn self-rellanoe, and by the further reaponsibilities of wohing dishes and keoring the oamp ground olean, they learn cooperation and sense of responsibility. The manner in which these rosponsiblities are placed upon the ompers is also important. The ohildren will oooperate more willingly if they have part in the distribution of duties, and a plan is made rlexible onough to allow a change in duties for the rarious oampers.

At Nerry Lodges the duties each oamper has during the week, such as washing and dryine dishes, setting the table, ot cotera, are ohosen In a group weeting of the ontire camp the first night of each poriod. A achedule is made from the camper" oholoes with the oounselors' advioe. At Dan Beard each tent group is responsible for 1 t own headquarters. Carp Chelan has a well organized system of dutles perfornec by the K.P.'s or "kitohen polloe." Brery K.F. who is nooepted at Chelan has the privilege of raking her own expenses besides taking part in

38. Lleberan, Joshus, Creative Camping, Now York, Assoolation Press, 1931, p. 24 . 
the camp sotitites. She has sotaln dutle to purfor such as helping

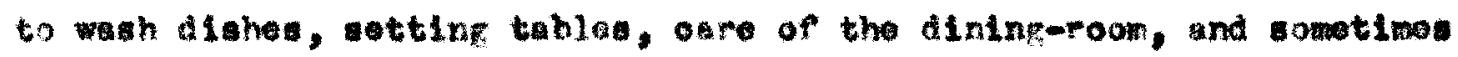

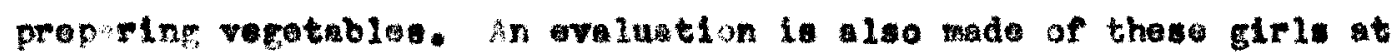
the and of the oup pertad by tho diotiolun. The ragular oampere nuat koop their oablrs olean and help kop the frounds olean. At tho flowingo two boy from on thable aerve their table at overy weal. The

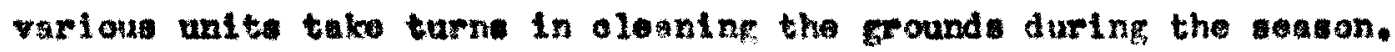
At the Camp for Colored Cirls the an pare wneh and dry the dishem

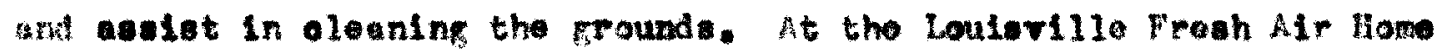
two pers ons from ooh table ah and dry the dishes after overy mol.

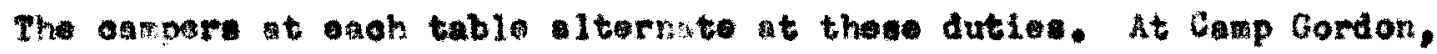

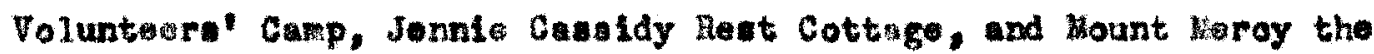
amper have only the responablitty of kepine their own quartor olean.

The troops of Goverad Bridge Hesorration tale turne dolng "fatigue duty," that 1\%, oleaning the iltabon, pround, weterfort, ot octora. Tho dishes aro wated by the boys 160, who take turns during tho osmp senon.

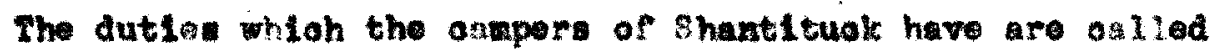
"oncers," onah patrol having "aper" to parfora overy day. A ohurt 1 mad of these dutios loleaning the lodge, swooplng the floor, laylng

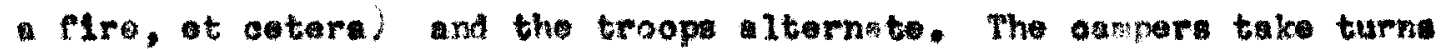
Asily in washing and drying the dishes and aotbine the tablos. Re11glous obserranes

Some type of religiou service whioh evolves ather from the oamp

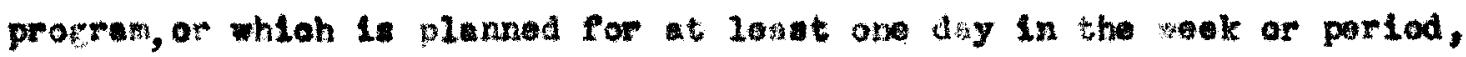

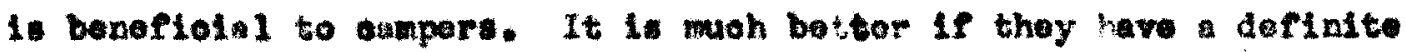


part in the serviee, elther planaing it with the otaff or by themeelves. The service often womm more to the oumpors if it is not a formal one, but one in whioh all ohsta, and in which subjoote direatiy relatod to the onpers are discused. A will ohoeen olte may frord beatiful

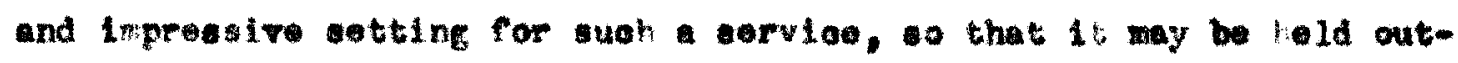
of doore when posiblo.

Chmoh eervioes at whioh uttondanoo it enoouraged are hald ot Covared Bridge Raserration on sundicy, ahepel on hillalde. The Cuthollo boys are brought inte louknille to ohuroh. The familles of the Lou1nvil2 Fresh Air How my attend Sunday cohool and ohuroh at Pewee Talley. In once of rain, wrove are oonduoted in the reorentional hall ot oamp.

\$1noe ralletous latruotion plays an important part in the proaran of camp Cordon, devotional priod lo hold every nornine at canp. The rellglous director of Dan Bard is in oum 11 during the oamp

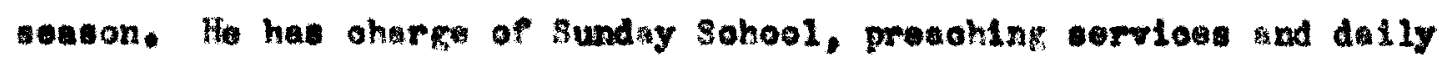
relifione Inotruotion. Sunday sohool attandano it not roquired. Fveryone is appoed to thend ahort rollgious actioe on Sunday afternoon.

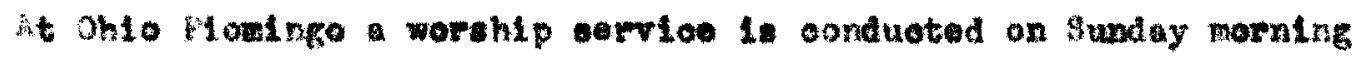
and voper service to held on sunday evaning. Attendano is not obligatory at ather. A worship wervioe is held overy morning, each undt or

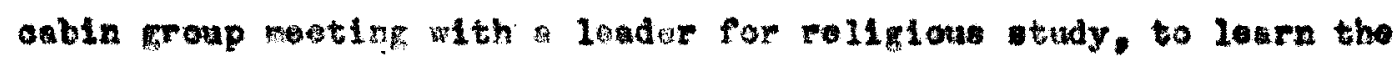
Christien way of ooplne with the aimple problems of 11fo. The oamp fire propram in the evoning are oloned with o hym and prayer.

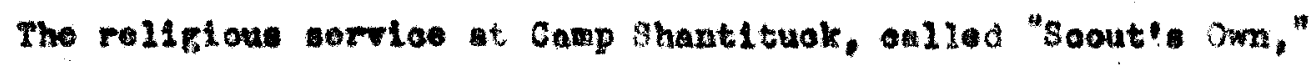


1. oonduoted on Suntay and in several gonoral ounfine durlig the week.

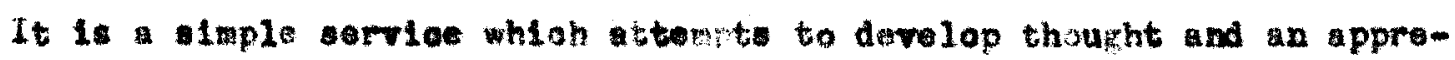
alation of the plrer thing in 11 ra.

Blblo sohool whioh a 1 anmers attent is 3 part of the dally prograt of the Volunteora' camp. The Cathollo gifls at Jonnie cassidy

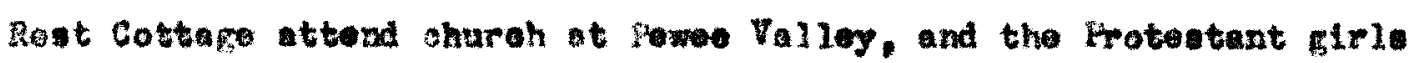
oonduot their om sunday sohool in tho reoretion hal. Somo roliglous

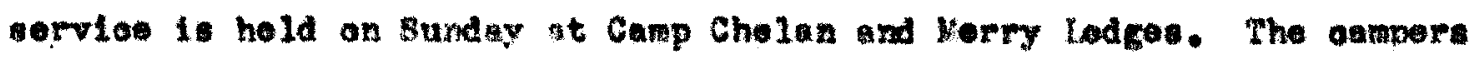
st hount Heroy las attend ohuroh on sunday.

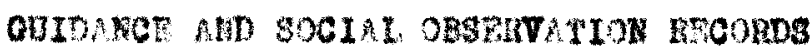

The guidanoe whloh the oncpor roodres during the amp season 1e extromely inportant, not only a it alds or retarde his adjugtant to the omp stution, but also in ite 1:fluonoe upon his developent durinf oam. every effort ahould be made to underatand asah oarser as retanled and influenood by his personity, hio onvironmont, his family history, his experience, nd his proaent desires and neids, The import-

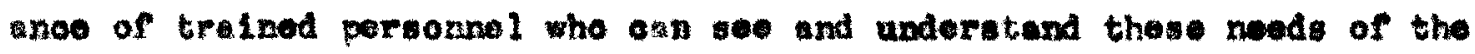
onlid has been stroneed in the section on Personnel, but my woll be repeated here. for the guldunoe of the ohtld during oatp cepande more on this factor than on any othe". If an underatunding of each ird1vidul is heartily destred by the oounselor who is reaponelble for the ohlldren in his roun, more effetive guldenee will be obtained, he guldanse of eampers should be based upon lapleal, sincere pereeption 
of the Indiridul's need for bew oxperienoe, seourlty, recognition and ponas. 39$)$

Eereonal roords of esoh osmor are helpoul in studying the ohid's development over periad of years. Suoh rooords aro an important pert of the program of any oum whoh attatio to stimalate the inditidusl growth of 1 ta work. Sugeations from the parents of oan amper, ompled with oareful obervation of boherior durtife camp by the oounselor, w11 help to arsate more symethetio understanding

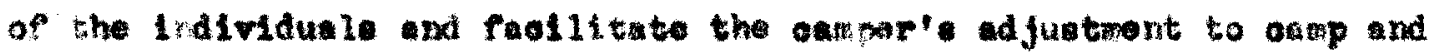

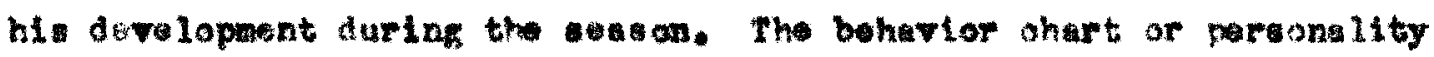

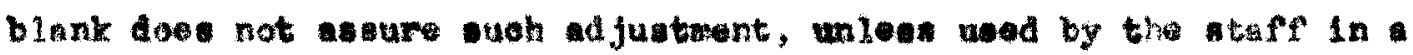
oomprohens ive way.

If new oouneolors are obtaind enoh year, whish is often the ane In the loulerille campe, reoord of the aht la le very helprul to the new nember in undoratending the ohlld. Nooorde aro also uaeful to orgenizetions whioh anry on work during the fost of tho yoar with a number of the ame ohlldren who attend astop. Too often when puldana is left to the oounselor' ablilty slone, and no written reoord of the ohild Is kept, auporfialal prograt is carried out. It io desirablo

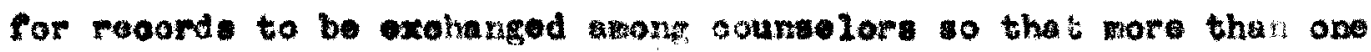
porson'e optnton af the ohlld le obtu ned. Teaords should also be read and wanted by the direotor. who my point out the norite or defects in the thods used. Dlacusion of reoord may take place

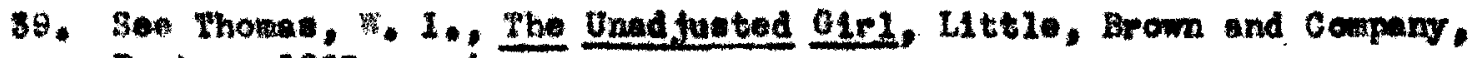
Bouton, 1923, p. 4. 
at the counedora' metings, but arten there is only tim to disoun: problets. In suoh ans bohuvior oharts and rooonds of perenolity foctor are ueful in learning the sause of the problem.

Interview with the parents of each eampor corvo as a very of-

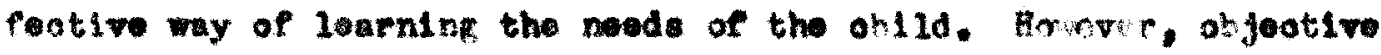
Flew are not awaye Iren by the parent, and the trie altuation 10 not lwaye diseovered unleas obtained by tratned intarviewer. An inforattion blank oowoerning the ouaper whloh le fllled out by the pertints is another whoth whioh be used.

The factora noted on oharte may be of grout beroflt to the outumselor in onoouraging the omper to atrangthon his woaker pointe and to rea1130 his higher ins. Frogress anouraged in anstruative way by the sounseler on not be too btronely emmesized. The ohart is effeotive for uee as an indiation of the progrese the oumper is making. A better resthod to the narrative report of eash oapper' beherior during onmp witton th the objective provionely disoused kept in view. Howerar,

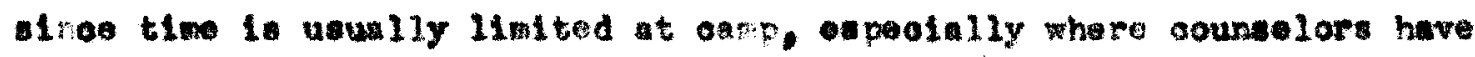
nuber of dutles, the ohooldng nothod is aoro raluable than nono at all. A good froxp loader rotices ohildren who geon to be led justed and to are elthor unable or umbilin, to enter into ootivitios, and disouses those Individunl osses with other atafe nonbors in his divi10n. If the problem is not readily solved, the motter should bo called to the attention of the dirootor. He lso keeps reoord of the ohildrer's development, thelp pertiaiption in eotritte under his supervision or those direoted by prealal activity leadere, and writes a report 


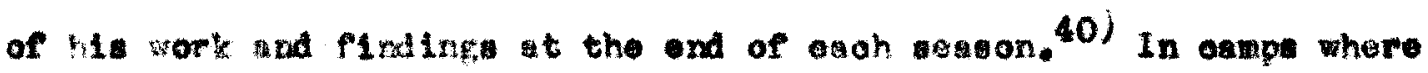
g fully trained purson annot be obtalned, elther the direator or eome

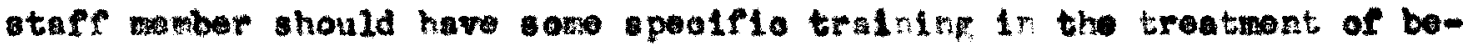
havior poblens of ahildren. A noyohintriat who may bo alled upon for

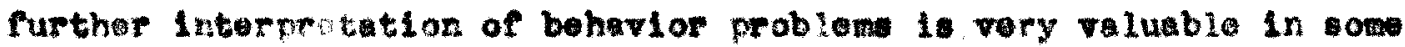
og868*

An Indiridual study is made of aon pirl at morry ledgea. This

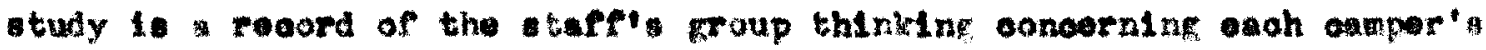
Intersats and remotions in the sroup, the group's attitude townd hor, and hor fromth in knowlodge, kl11., and soolal attitudea. The dootor's oplation of the cencrel phystonl condition la noted. Consideration Is Iren to the effeot whioh the esep has had upon the oamper. The oounselor at Werry iadges advilues of th the emper after the froup mootine ooncerning her. A aase hiotory is kept of coch individual wo 1 s a potontial onmer at korry ladges, and the selention of persons who ro to oap Is based upon this rooord to oortain extont. Then groter num-

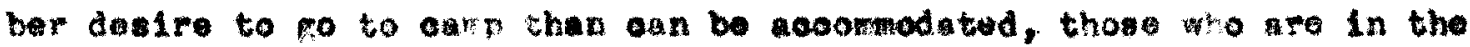
Freatest nood of emp are elected by the direotor or toff cooording to this onse reoord.

Camp onelon he blank regarding the ohild which the paront is

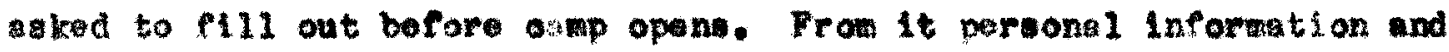
scolal habits of the onl1a so obtained. The oontribution whioh the parent fools that oarp on mike toward the devolopment of the ohild and othr augeations are raquated. In addition to the raord, the dirootor

10. For further dieotuaton see Lieberman, J., Creative Canoting, pp. 152-3. 
attempts to interview at loast one of the parents of each camper before oamp opens.

At Chelan the counselor guldes eash onmper in the group for whioh whe is responsible, and tries to oorreot any beharior problems whioh arise. This counselor alwo ohooks behavior frequenoy rating soule on anch of the ohlldren under her oare. The forme of behavior are oheoked as ocourring rarely, oocasionally, frequently, or very often. The direotor and head oounselora, most of whon have had adolesoent or oh1ld psychology, adrise the oounselors in stafe meting regarding personality probleme of aampars.

There is no suoh well doroloped sygten of oharto used at tho camp for Colored Girls, as only a brief rooord is kept of oa oh ohlid, inoluding the name, address, age, and weight. A brief statement of the chlld's adjustment to osmp is made by the counselor at the end of the period. This may be of some help the rollowing yoar, but has no part in the guldanoe of the chlid during oarp. Behavior problems are sometimes disoussed with the parent, with a repreaentative of the agenoy seading the ohild to oamp, or ith the dirootor.

The direotor of Ohio Plomingo plans to have parents f111 out an information blank next season, in an attempt to loarn the ohild's neede and habits, akills, and the maln reason why the parents wish the child to attend oamp. If real attempt to seo the roode filled is made at camp. the information gathered will be worth whlle. A beharior observetion ohart is oheoked by the oounselors during the on period. One adrantage of this ohart is that it provides opportunity for two ratings rather than one. A chart whioh inoludes only the one rating 18 apt to 
bo 108 progresalve, for ono whioh 18 oheoked but onoe is umually

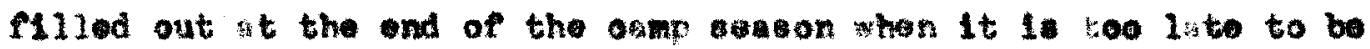
nolpful in tho mulanoe of the onper. Natinge ano only to bo mado whon tho leader has observed bohavior thoroughy enough to rate with romeonalio confidenoe. The rater is also ingtructed to be froe from

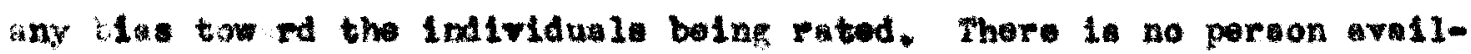

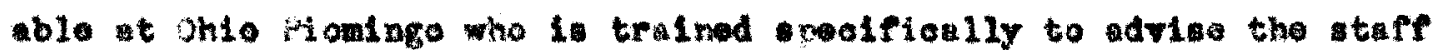
about the troutwent of beharior probleme. An interviar is hold with sampars who present epoolsl problema. If the oounselor ounnot work out an adjuetmont, the boy is roformed to the direator.

A sonfldentio I information blank fillod out by the puronte is used by Cap Shntituok In order to learn the ongour' intoreste and abilities. Thio 10 Antiar to thot wed by camp thelan for the ano purpose. The parent who whathe to disouse the ohild'g pragran at oup may confer with the dirvotor and stafe by visitine oarp. The obaerva-

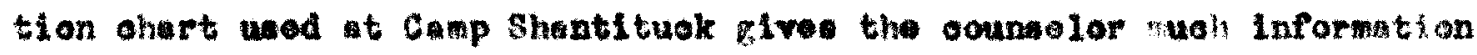

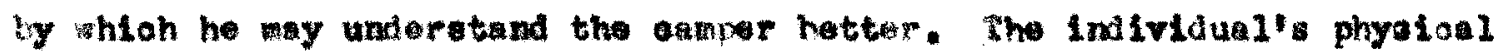
Mtnese for oamp, appemranoo, habits, attitud de, personal1ty, and bil-

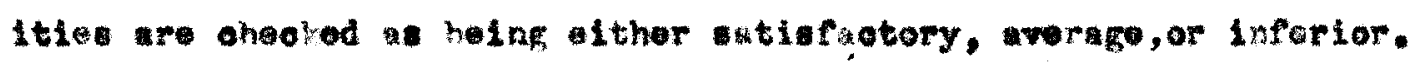
If usod Ith the Idea of progress for the enmpor in wind, this ohart may be vary helprul gulde.

The uxt eymten, used by capp shantituok, is planued so that the unt londer's gudanee will contribute to the Individual development of the aampers. The leaders get sowe tring for trenting personality problems frow ayohologlet during pro-omp trainiat. 


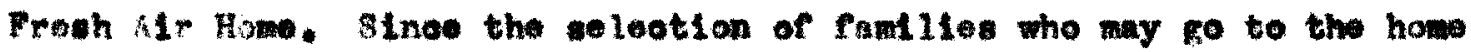
1. bued upon the noed for open if, eunilght, and othor helth-buliding

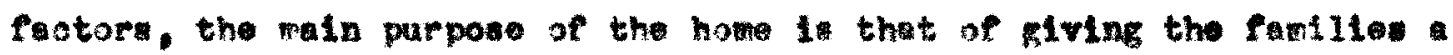
vaeation in the country. A roport of the Loulevilie Freah Air howe, chomiay, the diffioulty of lonrning the true bakground of the famille

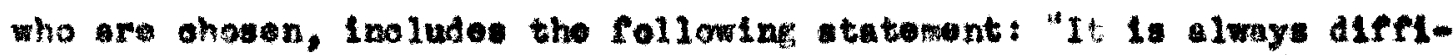
oult to find out informbtion about wages. One weok a job--tiro weoke no job--the reluotance of sone to seen poor, and the undilingress of others

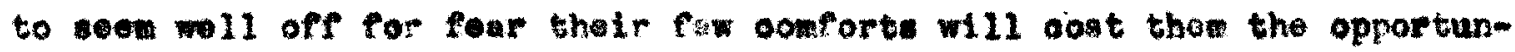
1ty of golng to the how, are diffloulties in the way of faot finding.

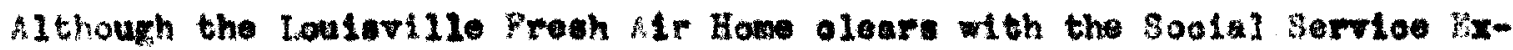

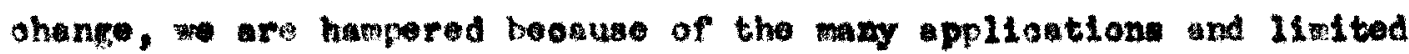
time for Investifation." Guoh faots show that the type of information needed for the mont efreetive rufdanoe is not always alind. then the

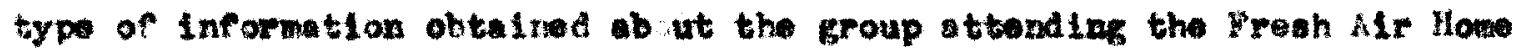
is Iimited to whother the Indiridual has a deoent onough wage to mintain

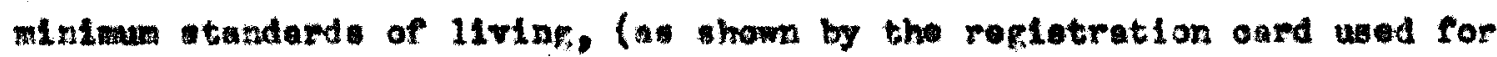
applioute), Ittle information reletive to the tadividuale" coolol dom

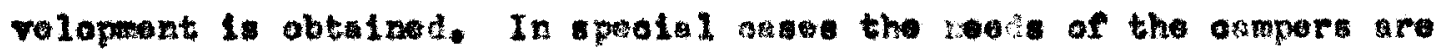

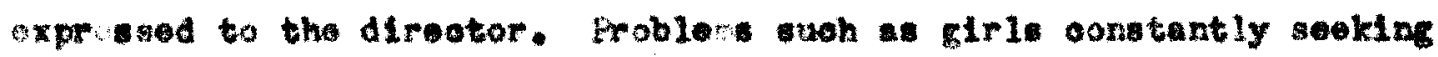
the cokpany of boye, or porsonel1ty omfliote, are dimoused with the dreotor. The dirootor uouslly tries to solve these problawe by fing them extre work to do. If bhis does not rewedy the altutalon, the ohildren are sent howa."

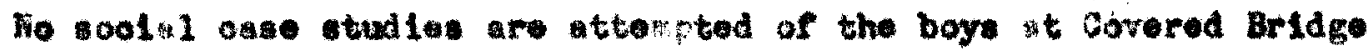
lieservation. The coout mater's oontaote wh the boy in ble troop 
durinw the year is the only ind lowion he has of the boy" backeround

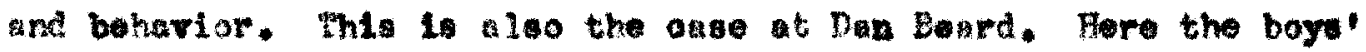
bohavior is not disoured unlos an individual prosents o poolal prob1am. The Alrootor of Covered Bridre Eeservation foll that thero is no neod for un advisor on bohaviop problems. This would soon very umeun In view of the faot that overy hhild neede om guidanoe in personallty

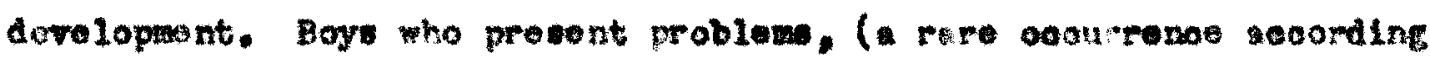
to the direotor). are oonanltad by the direotion and the Boy Soout rester in oomperenoe.

The alreotor of camp condon lesirns bit of the emrironuent, persone 11ty, and attitude of the oupers through olrolo weating with the firls during the vimer. Ho mitten reoorde are kept of this or of the Individual"s behavior during onmp. yot, there is no indiontion that tho loherior of the anapers is rogarded as factor in the gaidanoe of the Individule. The axp has not con boyond the plannites of cutiritios in the progeras development, other than pateing stress on rellflous train1nc. The saze thing is apparent in the propran of the Volunteer" Camp.

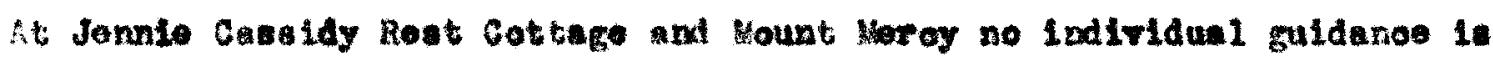
attenptod. The value of the typo of galdano and records whloh bave been

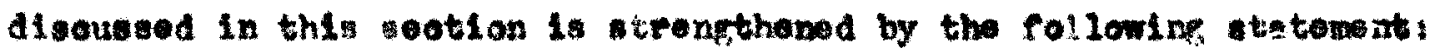

Basio to the indiridual approach is information about the aamper whioh will help to arote plotwa of what the boy is really ilke, so that we asn beter underetend hitr, to the ond of adjusting him to the altuation arialue in the eroup. We wanky for this purpose the 1storest aheok 11at, the perand Intarriew, and the oase histary. we secure record of his physlosl condition and hi: soo 1 history. fint out how he gete along th hom and at sohoal. Durlne enmp we ohserve and reoort the behavior of the boy. The tempt to 


\begin{abstract}
discover the camper's interests as well as his needs. There is diatinotion between the two. The oardiag's intereat may be to beat the reoord in a fify yard dash whilo his nood is for 1088 trenuoue aotivity.
\end{abstract}

A very general history of the ohildren who are sent to some of the Loulerille oampe by the Fresh Alr Fund is written on blank prepared by the Loularille Counoll of Soolel Agenoles. This information is given to the direotor of the camp to which the ohild is sent, in an attempt to give the camp staff a better understanding of the onld.

\title{
OROUPIMO
}

The prooess of dividing the oampers into groups has formerly been exerolsed primarliy acoording to the eamper's ohoioe. Some oampe place ohildren from the ame location together. However, the opposite method would seom much more benefiolal, for oamp may give the ohlld who hac not formerly been away from howe in opportunity of boooming adjustod to a new enviroment, and of raking new friends. The oamp whioh plaoes the ohild with the same entiroments fectors which he has previously experienoed, Tils to take advantage of valuable opportunity to further the ahild's developwent. First of al1, in grouping, the ohild's reeds must be taken Into consideration. His desires ahould be onsidered in relation to hie needs. Foar on his part to be away from friends may be reoognized in Ita impllation, o that definite attempt may be mado to help the ohild be happy and oase in the now stuation.

41. Blumenthal, Louid H., Group Mork In Camplng, Now York, Assooiation Prese, 1937. 
the bofits of enall group or unite in oarp 11fo has alrody beon rocognised by many oun leadero, but unfortunately by fow in the Louivellie area.

Soout oaming operstes on a troop omplng bals, that is, ouoh

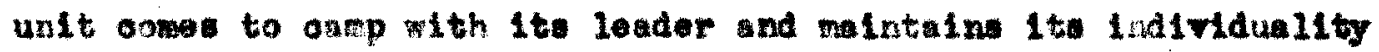
throughout. The troop worke as unit, planning Its om aotivitlos and 11ving as well defined group. Those indiridual groupe ooordinate

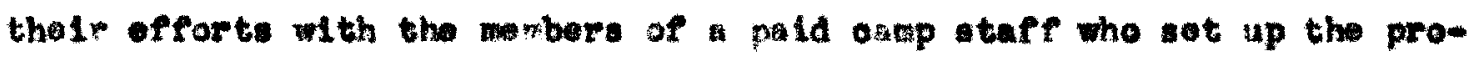
gram. This plan in effoot to Camp shentituok and covorod Bridge hoservat10n. The philosophy of the unit plan, acoording to the direotor of Onmp shantituok, Is bused on the 1do that ase onsplng 10 unsound that In the amil group the ohlld feels nore aooure, and better development of each personal1ty is posalble. It is folt that anit of more than sixton is too large. Dfton in onder to obtain entinfotory grouplas. oenpere aro allowed to lift from one unit to onother, not at their own froo w11, but in asnaltation with oounsolors, unt11 satiefautory adjustuent rosults. At shantituok oavpers aro arronged in uniti cooording to age. grade in wahool, friends in sohool, and phyaloul development. The whes of the parent ant the ohild are oonsldered then thoy arrive oaxp. At Covered Artdge Reservation thero aro unully four patrola (olght boye in a patrol) to stoop. waleinf up a omp untt. The units, onlled atookades, oxnelst of olght aholtare, with two londers' oubins

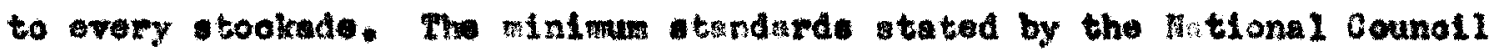
of Boy Sooute five on alear Iden of the reoping. the report tates:

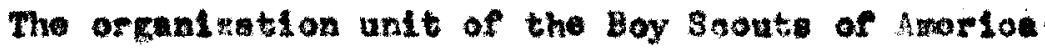
is the troop, utualig tade up of two of more putrols,

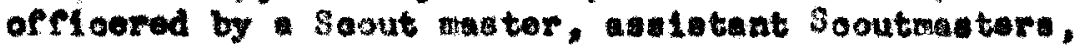


cenior patrol leacer, with oh patrol having a

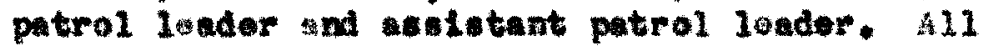
Soxut arping aht 11 bo so sonduated at to roookniwe this organlatian to the ond that the troop whall be trengthened as worling unit. Each troop golng to eamp ahould have ita apediflo objoetive alearly toted and uxtoretood, and plabe dafinitely 1ald for reaching or proprowing townet that sojoot1ve. Loonl counot 1 obpe are combated on the prinalple that ons ito is being administered for the benefit of number of troop as matter of coonony and to coour the benerit inhor nt in ooerdination and cooporation, but und ar no oiroumstanoes ahall the Individulity of the troopt or its lesdershlp be suberered. Bvery opportunity shal1 bo presented for the regletered or provialonal troop to funotion a. undt. 4 t)

The boye at Coverod Bridge heserration who do not oone to ounp wth their troop wre called "orphans" and aselgapd to a provisional troop. The payohologienl efreot of such aystem on the "orphans" has apparantly boen aver looirad.

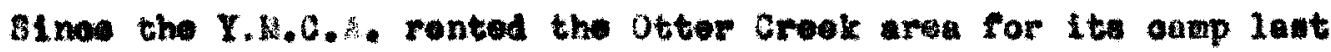

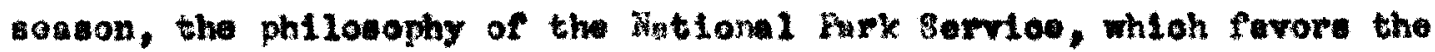
unit leyout she beot plan of grouping, was infocted into the aytom at Thio Plomingo. Jullan Bolomon, fleld ovordingtor of the Hational Hark Service saye:

To serve Ite purpose auocesefully, unit should be

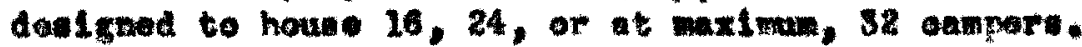
8mil und ta ke it peasible to aroup ohildren se-

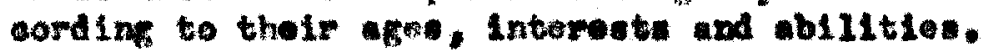
Suoh roupling lis pormlte high degroe of pereonal attention on the part of the oounelore, whereas

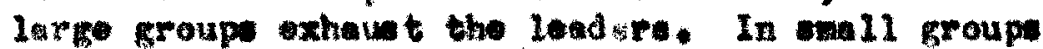
the ohild has ohano to flud himele, snd to adept himelf ensily to on livins ondition. children in Iarge group beoome orer-atimulated, and the

42. Wutional Cound1 of Boy sooute of Morloa, MInImun Standard RequLrenente for Boy Beaut Conpa. 


\begin{abstract}
poastbllitio for fotigue are greatiy inoreased when a large nuber of ohlidren as, leop nonorally Ire In too olose guarter. Kelses and disturbances and probleme of aleolpline all inorease proportionately to the elas of the group that is housed together. In addition to the ressone there are loo sound hell 1 th rason why 125 group should not 11 to tom gother in oampe. Gomuntomble disenses not no 11 kely to proad and on be more anelly controlled whore the rroupe are kept sul1. A1l of thone rosson for Aividing the eamp into sandi group apply oqually w 11 to the planning of camper' aleeplng obins. henever posible, not, pore than four oampore should be housed in osin. 43$)$
\end{abstract}

Thus wany of the polnte discussed proviously, have boen lineludud In the phllesophy of this unit plan. The majority of those parta have beon onrried out at Ohto Plowingo. The lack of adequate otare, disoused in the seotion on pereonnel, wa porhape tho grextest deflolonoy. The outpere of Ohis Houlngo are grouped wooording to s1ze, age, and friond chip. Not wore then rour boys haro beon put in abin.

The grouplag or eampere at the Loulerille Fresh Alr Howe has been areatly Influenoed by racli1tion avaliable. The mothers and bablos oooupy the lary Parker 0111 oottage. The girlat doratory and room for oamp counselore wre is the left winf of the adoinietration billding. The boys are groupod in the four chaok nocording to alze and aga. the arrange-

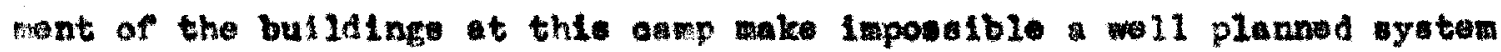
of mouplne suoh previously disoused,

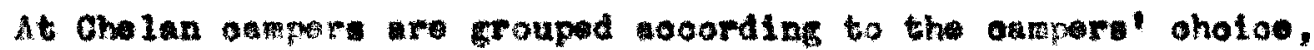
nolghborhood, cohool, sool l group, or ago. Tho evorage number 1t olght Firle to cabln. Fiftan oounoelor of a taff of twenty have oabin

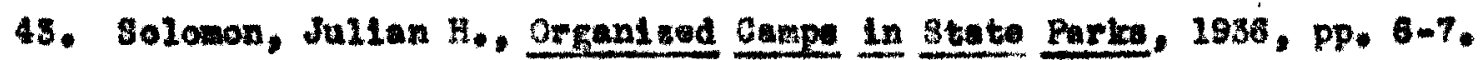




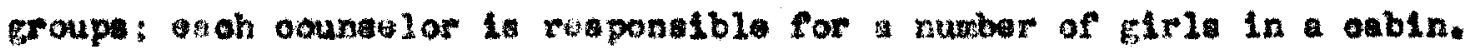
The cabtin councelor is rosponsible for the ohd ldron's tralning and adjustmont to camp. Tho cabin aro arrange in mita with muber of

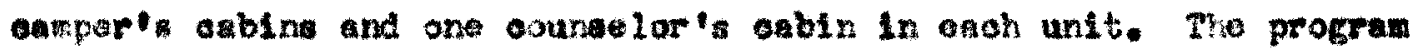
difere from the ooutins unit plan in that ativities are planned and partieipated in by tho orp a whole rather than in untto, as 1. the oase in soout ompe.

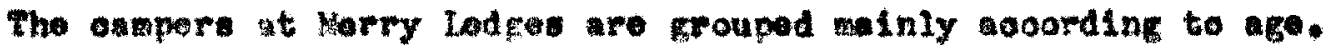
The 15 to eleven year ald froup are cent for ono poriod, and tho twolve to sixtoen froup sont for another period. The boys use the onp for

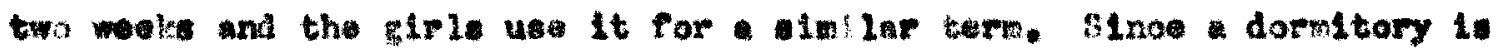

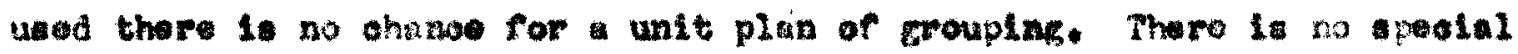

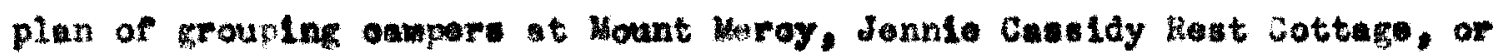
the Volunteers" Cunn. At Casp Oordor, the girle are grouped on a friend-

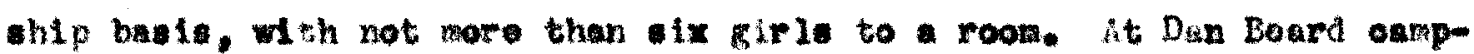
ors are grouped by troops, wth five to olght boye to a tent, in oldor boy, unully an Bagle 3oout, has diroot aupervialon oror oan tont.

The oempers the Camp for Colored Girls are groupod aoooralng to 2 ge. On rare oooasions they re llowed to ohange fron one tont to another. 10 the rason is eptroved by the dreotor. Ther are olght canpor to a tont, and a separate tont for oounselora.

\section{MORTVARION}

The prinolples of notivation anpe are a rital part of the prom Gram, Inos they are oo olowely relited to the Indiridul's dovelopant. 
Thether the ampor partio:pates in an ativity boauee of Intereat, or Whother he take pert because of the arked he w1I recelve if he ahowe nore ab116ty than the others, 1s extromily important. If tive onmpra are not intorested enough to partloipote wthout nothods of reward, the aetirity to ofther not one whioh they want or the aotivity is not made nttrative to the anmpers. Compulaton in cotivitien has long been autmoded as athod in omeng, but unfortun toly the oompotitive splrit st111 provalle in some oump to tao reat an extent. Somo oompetition

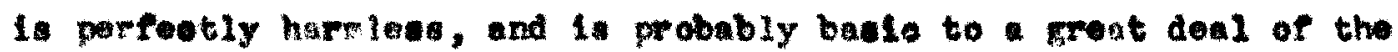
sport In games, ot eotere, but whan aerried to the polnt whore the

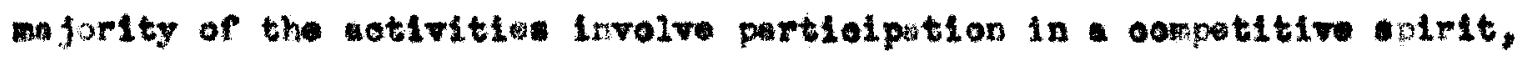
wth tho lites of rlotory uppernost, the efreote are often harmful. The

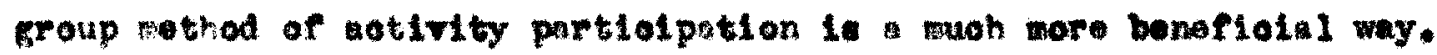

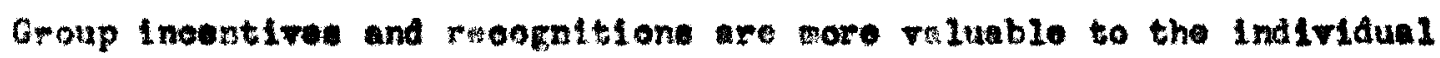
than waterial token ouch as oups, buttons, pennente, points, honors,

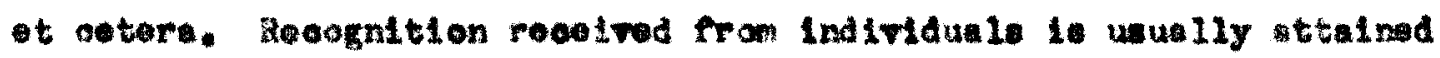
only on true morit and is oortainly more lauting than prizes. If competition is ourriod too far it is very opt to derelop the wrone aptrit In the ompers. Campera ay oven extabliah hablts of ohenting and Iylng In order to pet the award, and often osmpers who have physlos I linitatlong aubnit to etrenuoue extrtion to compote for the prize. The group pooese tenda to bring out soopotatro spirit in the Indiridul, whoreas the compotitive lement doe the opposite.

the direotor of Camp thelan doas not approve of giving awnede in difforont aotivitios, so that pattloipation is baed on interest alone. An thempt to promote sotivitiea is made to a limitod axtert in order 
to have all bulinnood program, but there to no ocmpulsion of roglmentation. Docasionally plnf-pong, budminton, of basoball tournaments ar axranged if the interest ir. the ativity lis strong enough to warrant 1t. The interested group ohallengos enother group, but oompet1tion hers is merely by-produet of intereat.

At the Frosh Alr Home much of the play lo ploced on oospot1-

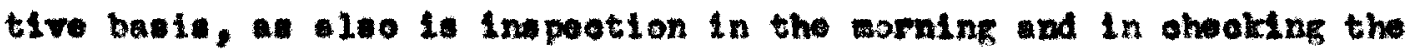
tables during we in. Rlbbons are given to each momber of the winning team. In the traok oabin croupe oompote agminut anoh other. Herotofore at Ohlo Plomingo, some of the direotora have been rather froe with amand but the prosent direotor adrocates alnost none. Feathore for nasiling number of tosts hare prevlously beon siven. Medel. for firet place in the track weot and in a number of other orents, have also beon awarded. Iast season ten polnts ware giren to the best cable eaoh day in onbin slean-up, and those were added to the pointe reselved by onbin whose unit won the basebull, owlming, traok, and rolloy bal1 beete. However, the future polloy in rogard to awarde at ohio Plomingo will to to give letters to ohlldren showing unueull growth or do-

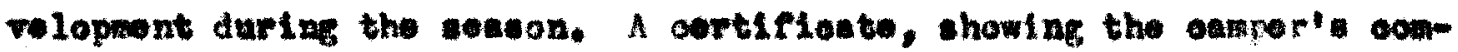
pletion of an aotivity, may be given. The basio phlloophy behind this ayetem appoers to be in opponition to awarda an inoutive for eotivity artiof pation. The former polloy will be repleoed by aooording rooognition to oarpers for having done omething woll. Although this Is an improvonent, resognition from the oumper group 10 atill denled prime Importance.

Covered Bridge Resorvation has well developed system of giring 
awards. The eyoten of bad fos is basto to the antire sooutinf prograx, edvanowent in rani being based upon the number of badges obtained. A the eystem is too lenthy to disousa hero, only the arards reluting direotly to the os progran w111 be disousaed. An arard is riven to the table which has the bast oonduct ocoh noal. A belt award systew

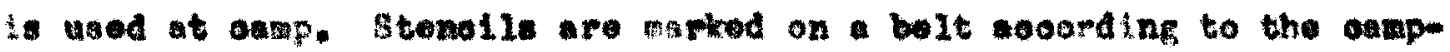
or'. achiovenonts in astivities. The wiming moet is oonduoted on an

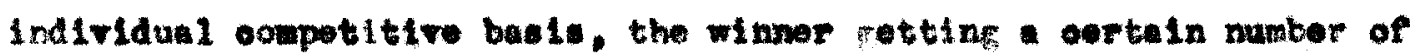
pointe. The test work for the nerit badges takes plaoe in the morning.

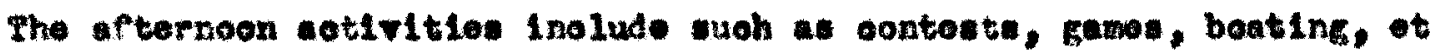

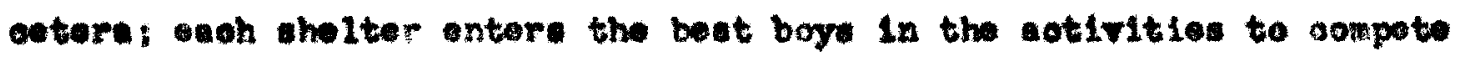
ageingt ench othor. In tho oventng attitites varlous ebeltora challenge ech other to ganes of rolleyball, bagoball, quolts, et cetera. A oatp honer Trabernity has beon establiabed in which boy nominated by the soout waster and eleoted by the troop mombers andergo the ordeal

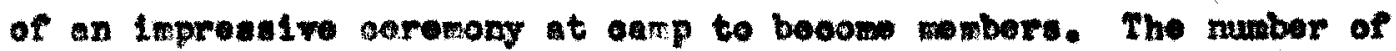
members in the troop attendinf onp deternine the muber of boye the troop way eleot to the bonor fraternity. Henoe the larger the number of bror.p montuera at, onmp the more boge the troop my eleot. Only acuncolor who are nombers of the fratarnity take mart in the ritual. Camp 1. the ollmax for the selection of those boy at they are celeated on the basis of their actions and attitude dwing the provious winter as 11 at anp.

The eame teat pasaing for the obtsining of badgea lo ourried on at Dan Band as at Corered Bridge Roenration. In addition to this.

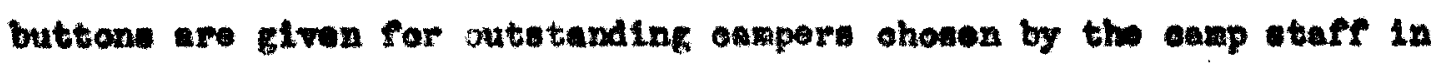


oonforonos. The reorostion progran lo bued largely upon so petition. At Norry led

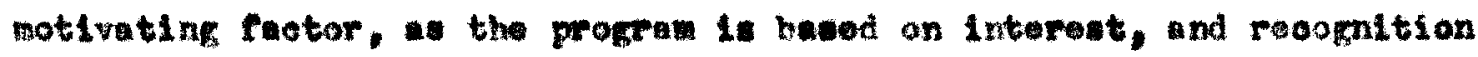
from the group it thought enfelotent.

At the Cump for Colored 0Irle prises are conetirie fiven to the ohlid who plans the best prografi or to the one who parforwe the bast.

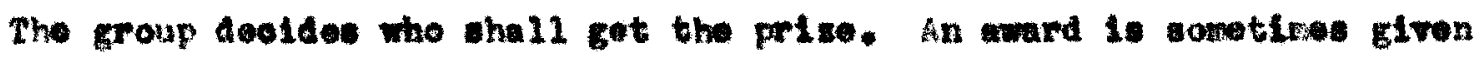
for the oarpers taking an interost in oortoin aotivity. In cotivity partielpation the ohlidren somotiwe form teaw by themelve with the help of tho sounelor, but oompetitive ganes are jot partiolpoted in as a wole.

There are no plane for ativity partiatpation Jenale Caseldy Ront Cottage, hount heroy, or Volunterer" Comp. At Carp Comdon ewards are given for the bot all around oampr, and to the oampere outetumiling in hendioraft, in derotions, and in aports. An wward is given to tho amper: whowe room is kept tho neatent. A polnt oyatem is ostublishod and the ancers are dirlded into tribes. An award is fiven to the win ning tribe. 8aw of the sotivitiog are partiolpatod in on a tournamant basis.

\section{EVALUATION}

It is obvlous to wary that in order to have proprose, one mat hare an oveluation of the progran or organization. It is wo ony to beoms imerned in progrem detall that on sometime forpete to stop and view the aning of the profram and to an if the prinolples are 


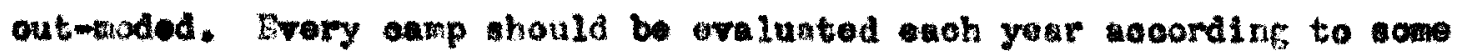

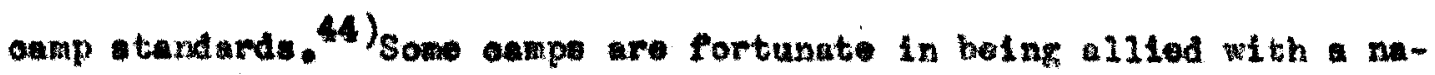
t Ional arganlsation whloh sots up tandards for the arganiation as a

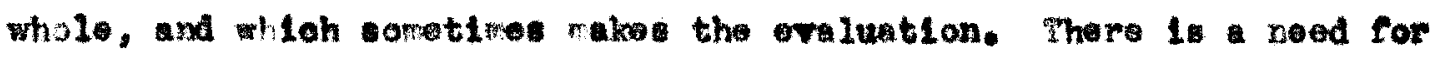

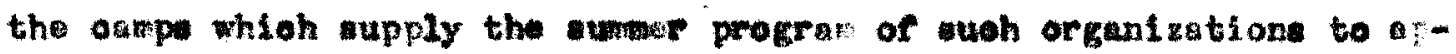
ply theo standarda in the 10091 omp. In attonpt to eraluate the progrom in rel tion to the neade in the communty an wall as to tho ob-

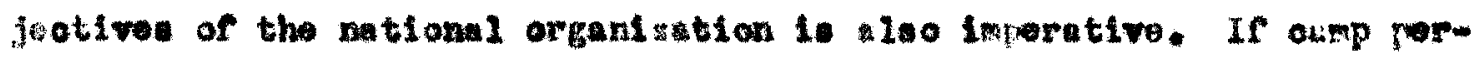

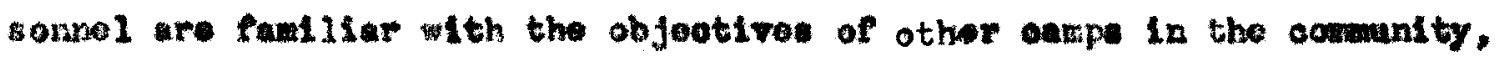

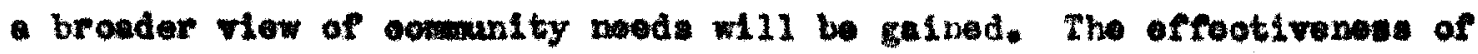
objeatives may be lournod in part by the reoulte of the camp experienoe

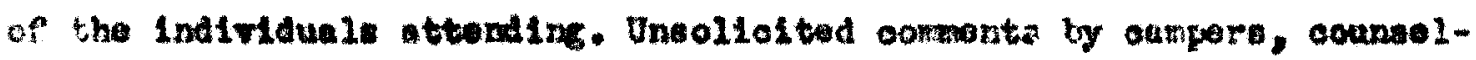
ors sind parente duriss of after oafp is one way so gain tholr opinion of tho value of the onap to thom. Reoordins of auch oralustions is more proftcable mothod, but of ton thoy are by word of routh, whioh may or way not have an influeno on tuture progran dereloponte lieoords of oamors dorelopesnt at the boginnipf and end of osmp are an imporsant menos of ovaluation. The proinal hould be in direct ralation to the objeotives, that is, if the mald objective is holth, the atandarda of ovaluation should be baed upon hoalth.

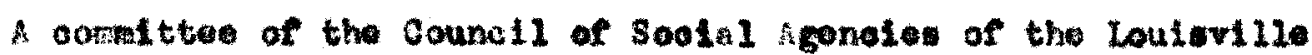
Communty ohomt mate atudy of Jennie Casaley Rat cottage in 1936 , to oondide the roed it we meting in prorlding rooktons for workin women. A furthor etudy was mado in 1939 through a osial aurvey under

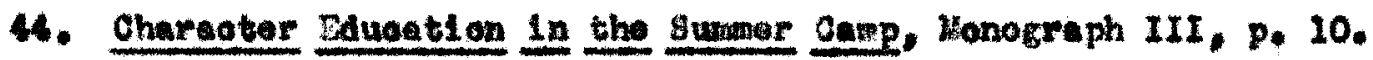


the suspises of the Louleville comanity che

A velf-atudy aooording to inter-eamp standards is made nt the Loulstille Fresh Atr Howe onstantly, matily through Neighborhood Houno. It the ond of the eumer the director and each of the oounalor mate a report ovaluating the ow p, ith the camper" views noorporated in the report.

Dach year the regional exeoutive of the Boy soouts Histu Cowm ored Brldg lleservation for a tour of inapotion. The minimum otandards for oamp are set up by the mtional organimation, and a report of the lool 1 amp if sont yonily to the natianal organization. oomente

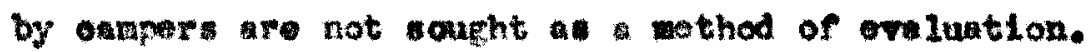

Last season, Ohio Plomingo wan wraluated by the tardarde of the Watlonal Hark Berviee, ae the Y.N.C.A. Fonted the oump oite fros the

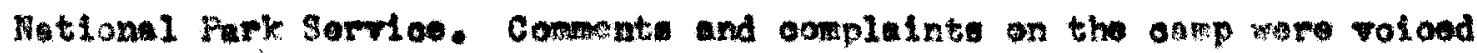
to the direotor by ounseloro, ouxpers, and visttors. A meting of the ataff wa hold after oamp olosed to obtin eupgostions as to improwwente for the future. During the winter a neting wa held to wioh the parente of the sampare tre invited, for the purpose of atting

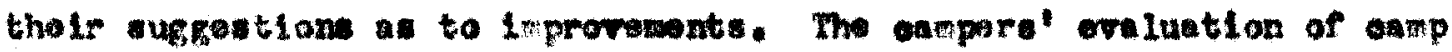

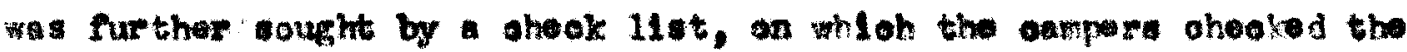
ton thing they IIkod nost about oaxp, ant the ten things thay disliked.

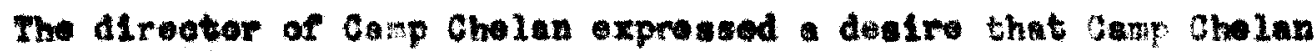
be oraluated gourly aoording to national or looal tanderde, Howover, the oxmp has only been apprated ono by n outeld group, when in 1937

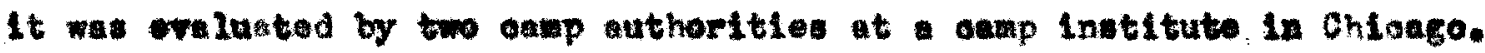

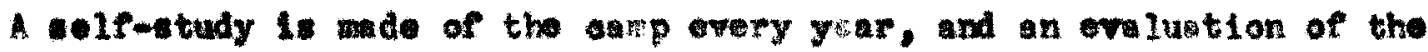


staf made by the direotor. The prograw is rated by the state a

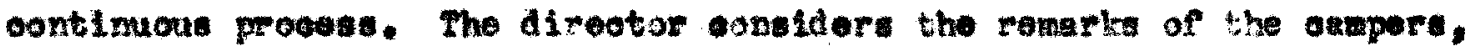
and further plans are being wade for the use of blanks to obtain paronta' opinian of the carp.

Camp Shantituok is oralustod yearly coosrding to tho rational Girl Soout Standarda et ther by voluntear or arofossional parson. The omp ataff, direotor, and exp oomittee make an evaluation of the program every yos, baved on tiona 1 tandards, visto, and obrurva-

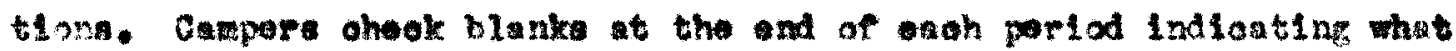
thoy liked about osmp and what they would lite the noxt yosr.

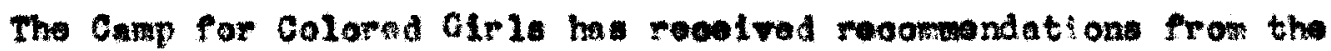
Ioulaville Board of Irate. A nelf-atudy of the amp in weds by the dirootor. Surgettion roled by the campers are noted, and some nvaluation obtained in the promp reting of the atanselors.

The oraluation of sarry vadgea is based on the opinion af tho

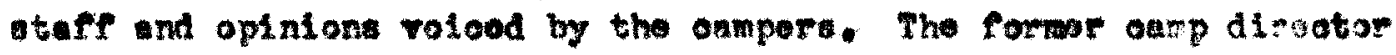

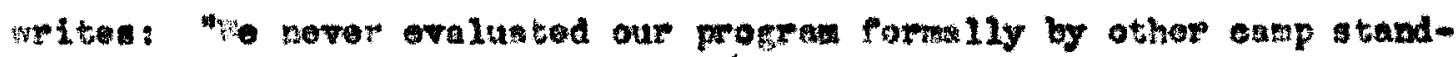
ardi exoept as I ovaluated our oxperlenses in the light of m formar

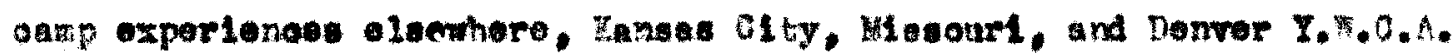
oamps, and ry rading and tudy of somp proprana."

A woport of Dan Beird Is rude by the looal direotor and sent to the Nationel Board of the Boy Booute. An eraluation of tho propram by the staff is Included in thle moport including rooconendations for the

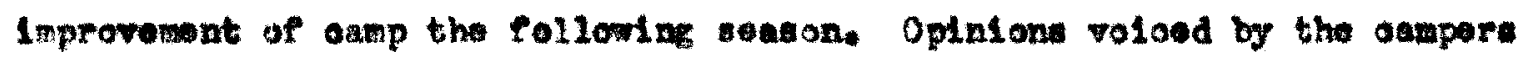
are kept in aldo. Defoct of the oamp are pointed out to the lational Inter-matal Comaltee. 
The oxly wathod of ovaluation developod thes far at camp fordon 13 thet of the ontpers at the and of the pertod, who write what thoy

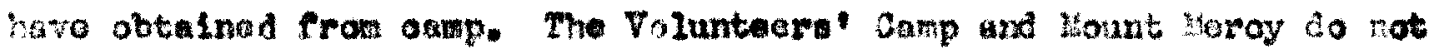
Indiosto any ovaluetion ather than that of the direator notinf oartaln phyolan 1 noedo from yor to your.

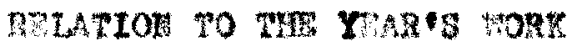

Uany of the apeote of the oapte relation to the your'e work have been disouseod prowlously, cuoh as making atudy of the how and

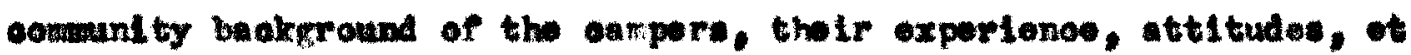
ootera. The ralue of the chlld bolng placed wh now aequalntanose,

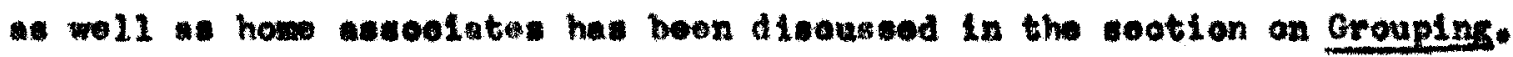
A further value to the onlid may be brought about if the orgarlation

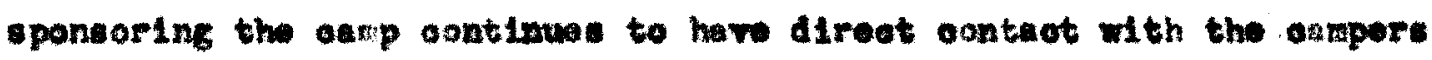
throughout the rear. Buch oontaot is poselble for some of the onep in

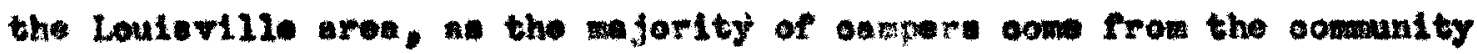
in whtoh the organteation is outablished. The oamp offere very reel opportunlty for olubs to forw, for at amp Indiridule boone coqualntod and corm frlendahipa. The dockre to be together orten aontime beyond oamp. If thle is followed in the vintor progras of the organizatione,

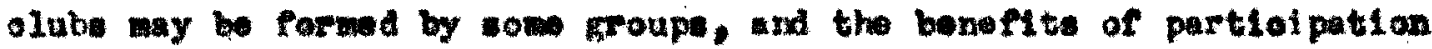

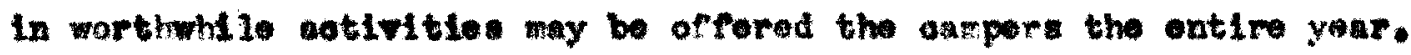
Some outlowent groups huve used this plan in tholr progran, as the ajortty of the eampera are those who partielpate in the ectivitied 


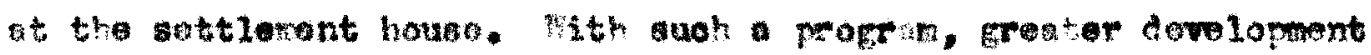
of tho Individual way bo brougt about, gi the oonteot with the ahild 16 otror longer pertat of timo.

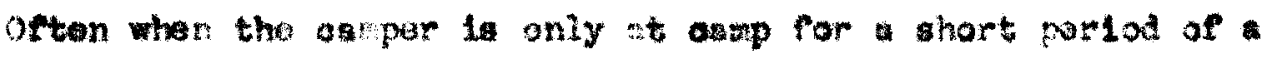
wo: or ton diva, it is diffloult to bring about moh d rolopmont on

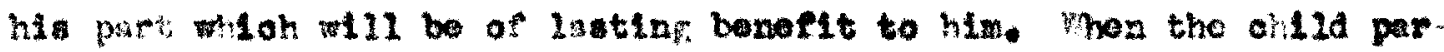
t5olpates in the orgats tion during the ontre yonr, suoh in in the saout troop or attlonent olub, the chanoos of bringing about a favor-

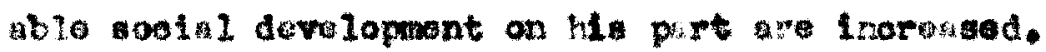

An opportanlty for further oamp planning is apperent if froupe are oontinud throughout the winter. The ohlidren may bogin to plan for anp during tho epring, addin now and bonofialal sufgestions for the coning savon's mogran. Camp has a woro dofinito noaninf and

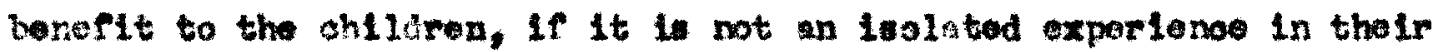
11vos. If wotivitio wre oontinued throughout the year, ohlidren may

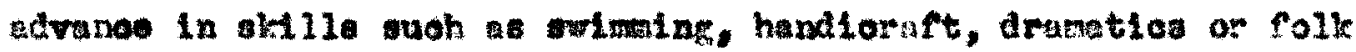
danclng so that mor advanoed programe may be offorod at osmp. areater opportunity for loaderahip tay be offored if oontact with oarpers is anrriod on throughout the whther. These young poople may be guallfled a junior counselor as omep, and 1uter oouncelore, thoreby solving the

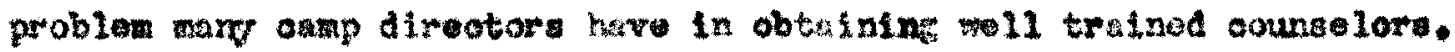

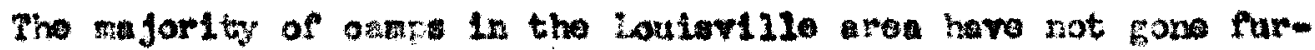

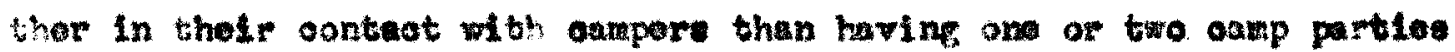

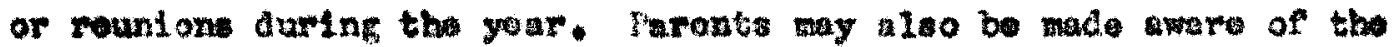
goule and opportunities of the oup by the organization's work durine the Inter. 
Soveral onp portios are given at the Y. .C.A. during tho year

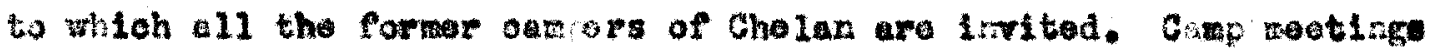
aro hold in the Junior Wh 30 hools in Hey and arp rounion pionio

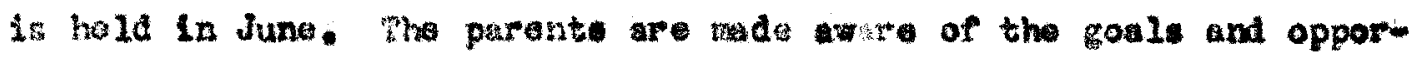
sunteios of the camp by eamp rollera, a porsonal intarviow with the dirootor, and by the blanit the parent f111s out beforo the chlld roos to oanp.

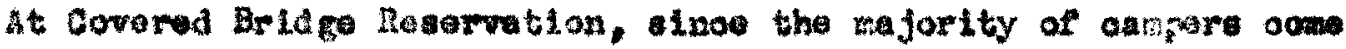
to anp with the troop to wiloh thoy bolong during the wister, eswp 19 aumer progran for the troops. Parents of the soouts are tado awars of the anp opportunities through oanp bullotine, cont out in

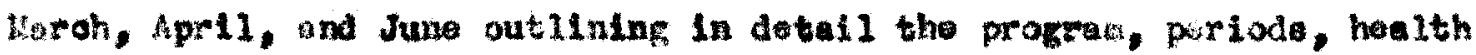
ond bafoty, stafe and oost, of the oamp.

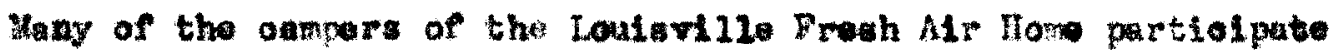
In the atirities at Noighborhood Hoube durine the winter, but thase liave no dofinite relation to oanp ontaots or groups. sas mary of the prents go to the howe, they oxperienoe the banefite of the rention home the wreas.

The Alreator ce canp Godon has oontaot with the abrors durins the yoar the junior oirolo motinge of the King's Daughtore. Ban-

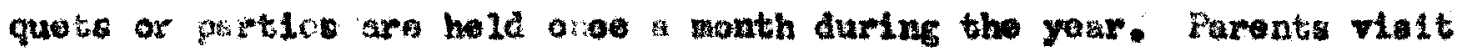
the and during the two weets pertal, and are Invited to the rinal banquet won awards are given to the campers. The direotor also talks to the parents before eamp opens, explainlng the objectives of the amap to them.

A oamp rounton of Dan Beard is held onoe year. Paronte are 


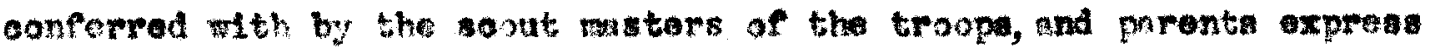
nods of the boys and benefte which the boys have roolved at amp.

Camore have no relation to tho winter mograw of the vilun-

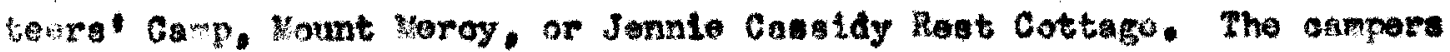

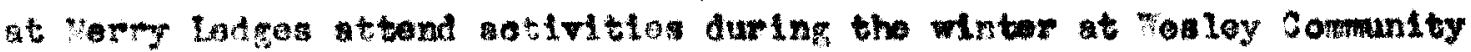
Wouse. The individual 1:terest of parents in the oampine progran, fosterod by atendire actiritian at the howe, is the only way in whioh thay are made arare of the amp opportunitiog.

The oontaota wade the Camp for Colored a1-is aro not carried

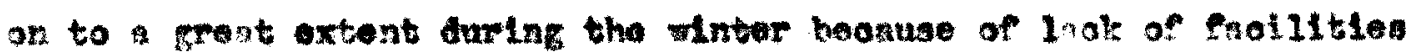
ad losdorshlp. Sowe ohurohos have organized alube of ohlidron who astended tho emp, but on $y$ a fow. The dirsotor neets the omp group

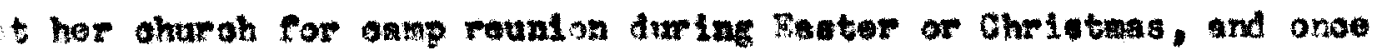
before oamp opons.

Thus san see that in most of the organizations studied thero 1. only 11 mited oontaot $w$ th the onlidren and parents aside from the oamp porlod. This ned is one which those arganlewtione may hope to 111 In the futum.

\section{gtanther}

Ae the objentires of ment of the eampe in the Louletille aroe

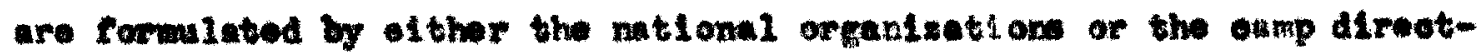

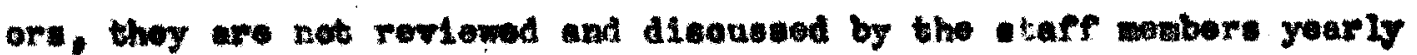
In ordar that thowe objective way be nore efreotivoly carried out in program. The lack of portlelpation of the exp group ns whole in 
program planning is 180 orident. The plan has hoon atertod at Camp CheItan, tho onmp for Colored Girla, Merry iedges, ant In the unts 3t Sare Shantituok.

In genergl more omphasis has been placed upon sotivitios in the Loulav1120 onms than upon tho individual devolopment of tho ondidron. The aotivity partioipation ha largely beon on an Individiol basin rathor than with tho group wet od. Those anpe which keop oamplete

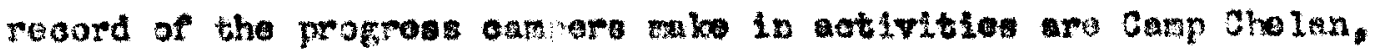
Dhio :3 mingo, Camp Shantituok, Cowored Brtege Renorvation, ant Dan Soard.

The oxyly orgariagatlons whioh onduot indiridunl gonoral sages

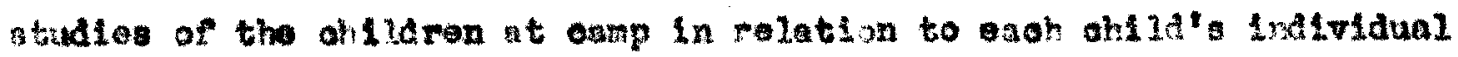
and soolal dovelopwent are kory lodgos, Camp onelan, and camp Bhanttuak. A behavior observation ohart ta kopt of onoh boy st Thto plomingo. The untt plan of grouplat disoused as the most sutiabio tor the typo of rogram advented onnot be onrried out by Norry Leagos, Dan Sourd, the Oump for Golsed Girls, Jannie Casaldy Rest Catsage, Mount

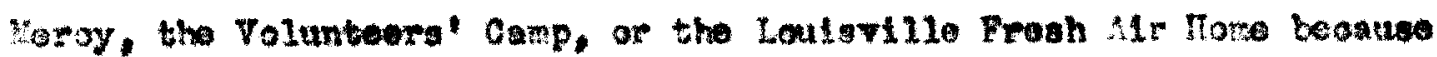
of the arrangemont of the buildings, but the prorrane may bo planned on a group basto.

It is hored that a further eveluatlon of the prozsats of these

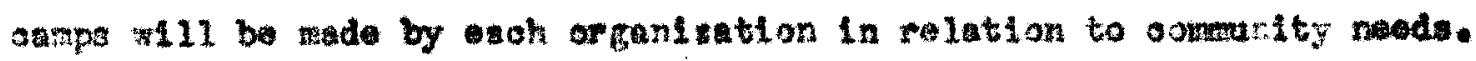


VI. ADUINISTRATTON 


\section{ADMIMISTRATIOn}

Sinoe woh infornation rogarding the adminiotration of the oupe In the Loulevilie are hae previoumly been preaented and dicounsed, this cootion is 11mited primarily to consideration of the oamp oomatted or

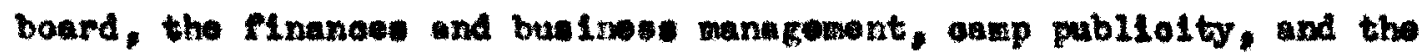
oamp' arrilition with national or lood eamping aesoolutions. The atarf noded for the buinese mangenent, and the adminlatration of pargonnel It dLeuned in the cotion on pereonnel. The adminictration of - casp oannot be thought of epart from progren buliding and the other ossentlal units of the eamr, al all of these are interwoven in pratios.

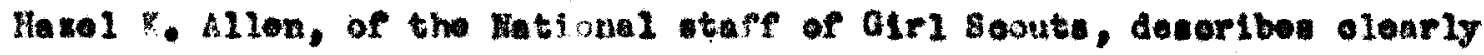
the danger of a canp whowe unite are not coordirated. She arya:

In twe candlar curp, when both progran and adminiotretion are earried by an imoat undifforentiated atafe, there is often langer of ovoremphes is in one direation at the expense of the other, cooording to the personal phllosophy and ebillty of the ultimetely responelble

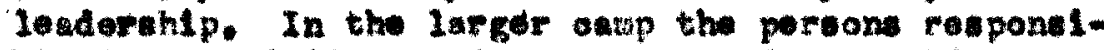
ble for the alfferent drelopente of eamp 11 fo may, a lmos t whout knowing it, go nemly separate way in cohterinf wht eash cancelvos to be the goel. A cloar undervtand Ing of the real purpose of empling for young pople and of the mothods for working that purpose out nouds to be held in oongen poevestion by the ooudttee and stare of any anp. 45 )

Thle neod for everyon related to the enes to have a olear underotanding of objeotives has been disoused more fully in the cootion on

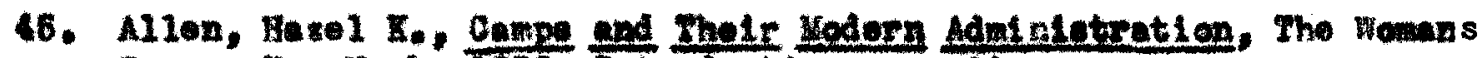
Prese, Now Yark, I850, Introduction, P. VII. 
program.

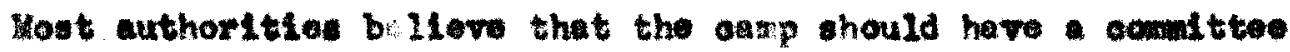
or board representative of the rublid, to help determine the operating polioles of the eurp. Qualifloations of poreno represented on anoh a oomitteo ere very important. Among auch gualifleatione are that the pereon hove interests and abilitles whoh will halp to make declelon

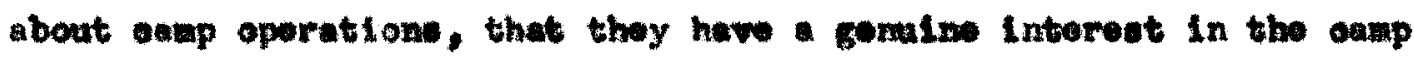
and Ite rolation to the conaunity. and that they be oulturally developed

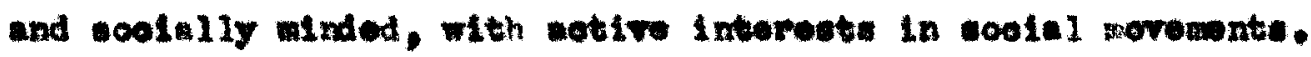

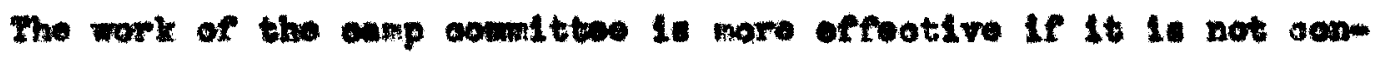
Fred to the eseson during with the casp is in operation. During the winter there is areollont oppertuntty for the etudy of the oanp program. In orgeniatione whioh oury on recrotional progren durlag the winter 1t Is oven areater. The winter monthe aleo provide tim for the stady

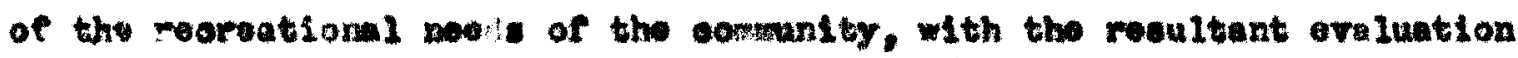
of the ablity of the oump to wet thone node, and for obudles of the

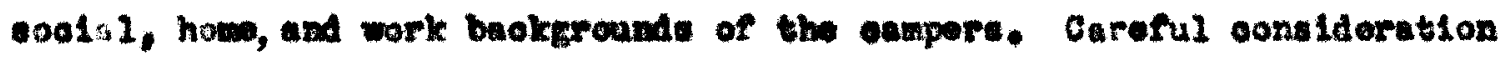
of the budget sow tim before eamp opens il alvo nooesary funotion of the oownat tou. (4)

A more domooratio mothod of determining the aap pollolo is

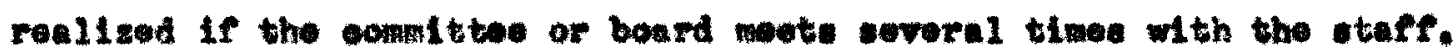
In the group moting the ldees of 11 may be poosed, wh a group ldea as the rooult, A betor underatinding on the part of 11 of the ind -

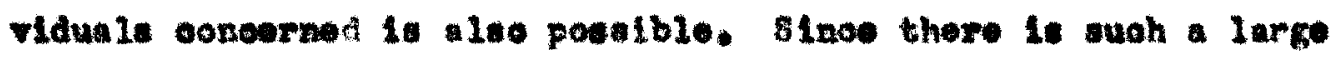

46. For furthor diecueston, we Allon, Hanel $x_{0}$, op. att. 


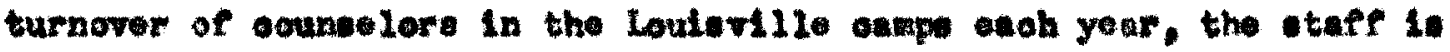
often obtalined too Inte for suoh a proesen to take place. Howerer, It 1s posaible ror the oomittee or bourd to andider reomendations of the an ers ond ouncelore of the previous season.

As the funotion of the oump ondteo or bond is unualiy edvisory, Ilmitod to the dotermination of anmp polloles, the prograre planning is regarded as sunotion of the camp alrootor, staff and oumpers, as previouly reoommonded in the wootion on program plenning. Howover, if

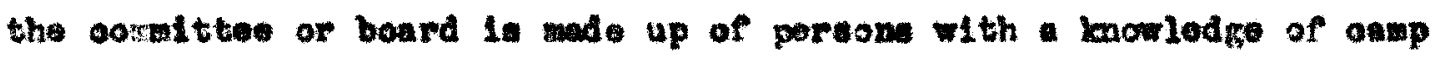

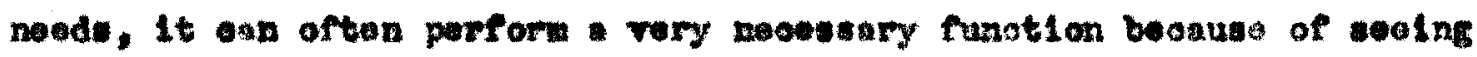
the enmp in wore objootive way than te posalble for the oamp dirsotor

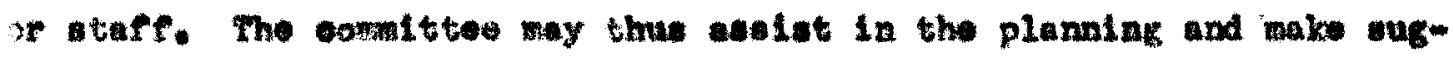
gostion far lmproverent in the future.

Al1 of the organdatione studied, Wth the exception of Jennle Caspldy Mest Cottage, Mount Waroy, The Camp for Colorod Girls, and the

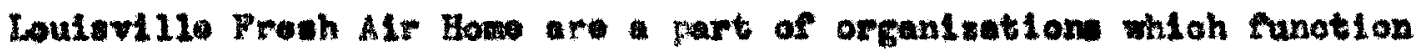
during the ontire year. Therefore the uminietretion of Casp chelen, Oh10 Plomingo, shantituok, Coverod Bridge Reworvation, Merry Ledges, Dan Beard, and of the Voluntears' Canp is rolated to the organisations of whloh they are part.

Corored Bridge Renervation and Dan Board are used in the sumer prograw of the Bey Soout Orgenisation. Shantituak In the OIrl soout Camp. Therefore those onmp are adminintered through their lookl ocum-

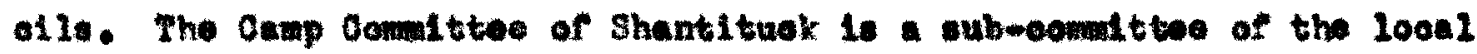
Board or Counoll of Cirl Boouts. This Board is oomposed of portons in the comaund ty who onn moke oontsibution to the bype of program which 
the Soout Organluation is ourrying out. The ohalrman of this Comitteo

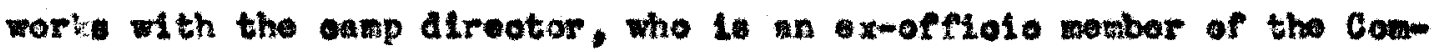
miser.

Cevered Bridge Reservation is under the superviston of the hitte Divieion of the Louleville Counell of Boy Soouts. An weoutive Beard,

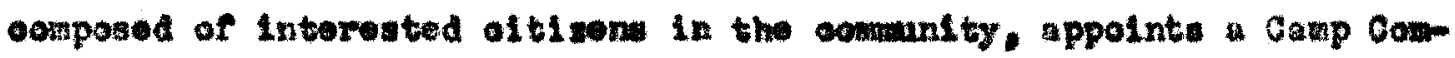

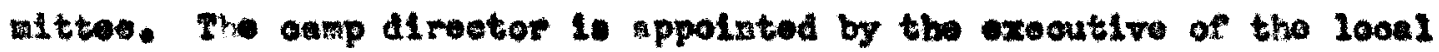
Counoli and approved by the Coumltbes. The exeative of the counoll and the omp direotor dotemine the operating pollotes of the oap and

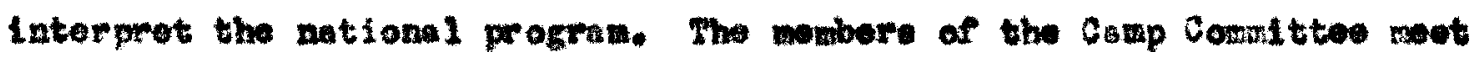
in the spring and P11, and attond oup soveral times to ohack on oon-

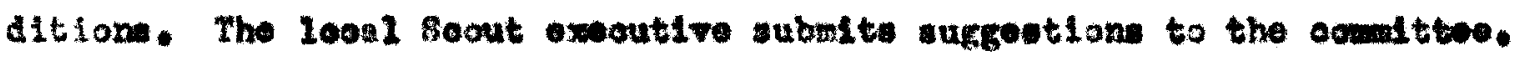
The Camp Comettee of Dan Beard il appolntad by an advisory Boare of the Colored Diviston of Boy scouts. The Camp Counttee is eomposed

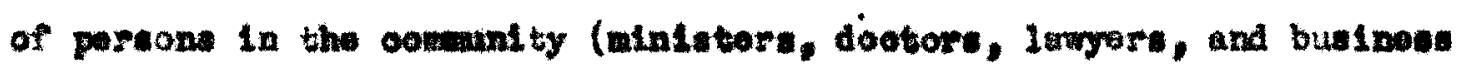
mon) who asulat the oump otaft in whing goneral plan for the oamp.

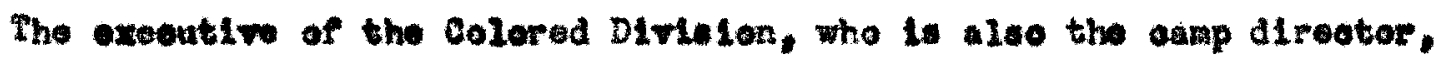
is an ex-orfloio momber of the Board.

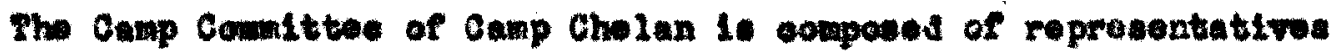

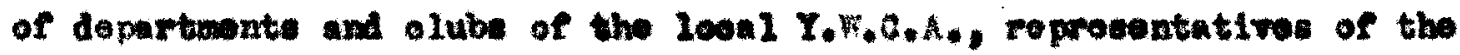
anep otafe, and reprenentstive oltinene in the ocmanity. The direotor bellewes that pareate of eampore should aleo be roproeented on this oomm nitter, and hoper that this wy booupliond in the future. The

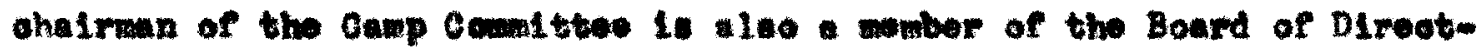

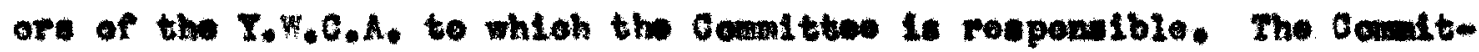

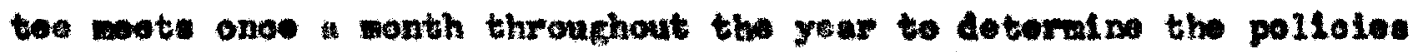


and wate plans for the oparation of the oap.

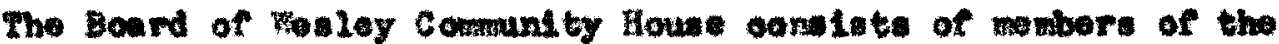
Wethodist Ohuroh, and worres an adriany Board for Nerry Lodges.

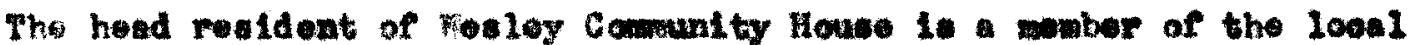

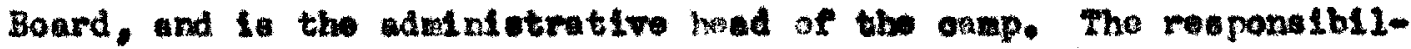

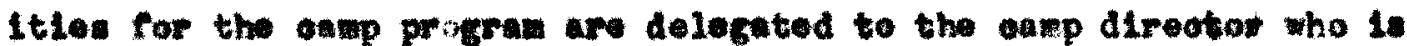
the girlet worker at the comunity howse.

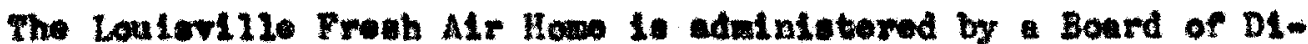
rootore, which detormine the operating polloles. The Bond consints

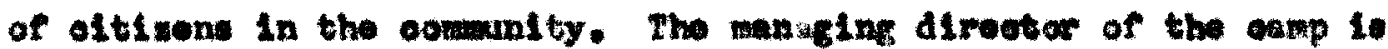
loo tho rloo-proalatent of the Board, and the haed reald ont of relghbor-

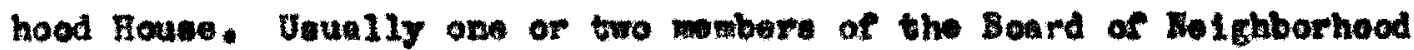
House are alse nombers of the Poard of the Louleville Prouh Alr Home. The Canp Gomitbe of Ohto Ploninge il reaponible to the Bourd of the look1 Y.M.C.h., whloh is oomposed of profosstonal and lay porsone in the comanity. The direetor works in oooperation with this

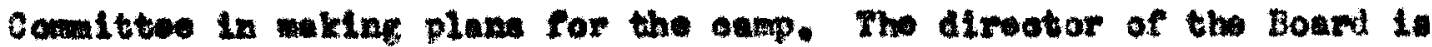
the ohalman of the comitteo.

The husband of the Alrootor of the Volunteera' Camp is a mer

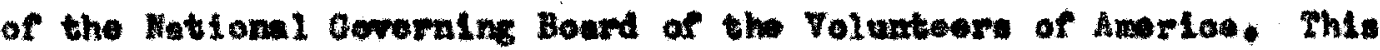
Board wete orory the wonthe, and dotermines the promran for tho

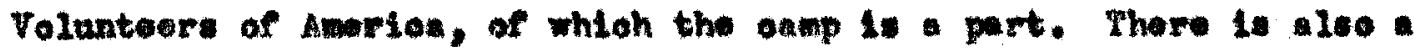

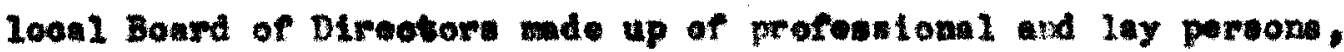
which weate ono month.

The Board of Jennie Casuldy llet Cottage, composed of appraxtmately Porty nomber of Protestant ohurohe in Loulevilie, determinoe 
the operating polleles. An adrisory Bownd of lawror and tro butinose mon is asliod upon ror legal adrioe, and to solve probleme of nanagoment. The director of damp Cordon is rasponetble for the edminlutrution and mangement of the osmp. She outmits a woport to the state Bond of

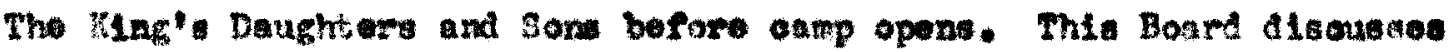
shede plane with the direstor and doterwinte the oporating polloles of the samp.

The direator of the Oump for colored Ai-le and a camp Camittoo

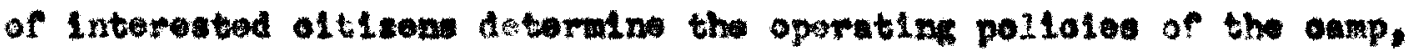
wioh are subjeet to the approvel of an advieory Board. The comatteo bets onee wonth durtag the winter, and twice wonit Irom kay to ootober.

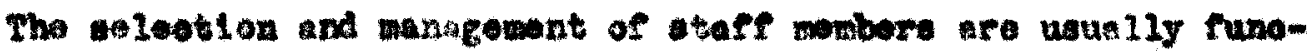

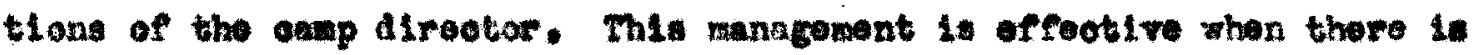
- Lear undoretarding and dertultion of onoh otafe mobar's raspons 1bil-

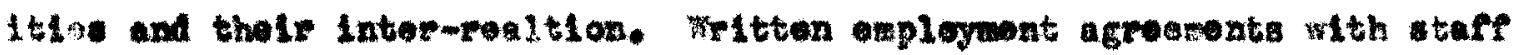

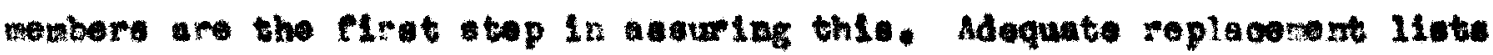

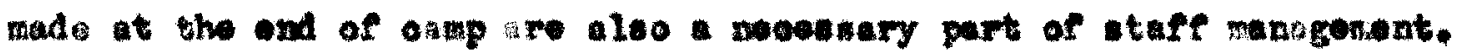

The melootl on of councelore at Ohle Plealngo, canp chelaz, camp

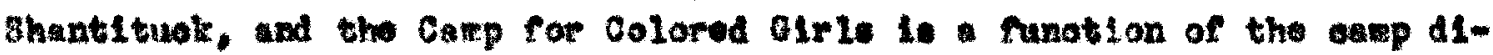

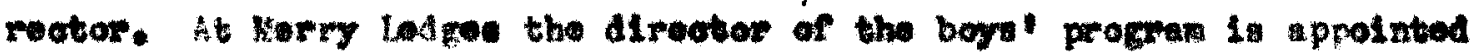

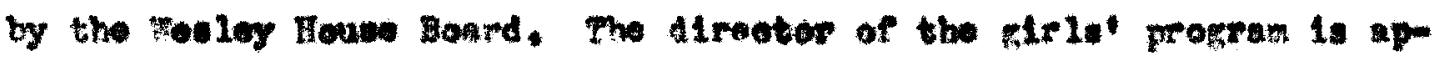
pointed by the touthern Uethediet churah canas1.

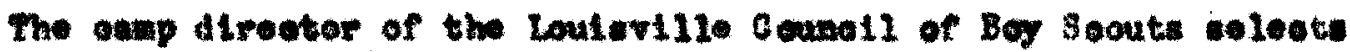

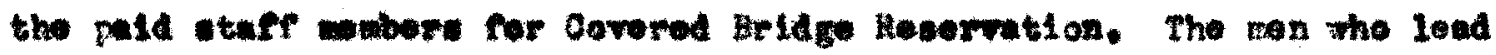
troope durlng the winter ooxtino this loaderaip at amp if the troop 
goos to samp. The same is true of the welection of the otaff of Dan Doard.

The directow of capp Oardon is appolnted by the Board of the

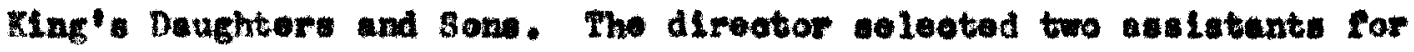
the two wele of the 1988 sason. The direator of the Volunteon" Cemp and ber hubband seleot the eapleyees. The direotorn are acaluted t camp by a winter and his w10. The Boart of Jennie Caneldy Rewt Cottage celoote the nutron or auperrieor who it in aharge of the how durling the sumer, and other enployeen.

The wanging direptor of the Louiwille Freah A15 Hom seleate the permanont bafe for the mason. Her rogontendation ere oubjeot to the approval of the Bourd. The manglng alfootor leo malea reoom-

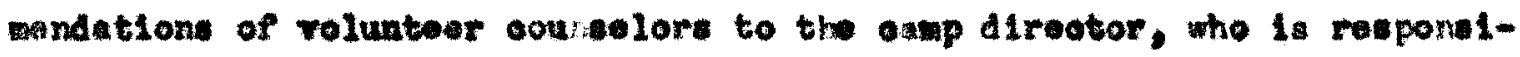

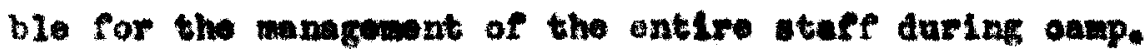

The direotor of Nount Horoy is aleo the cininistrative had and

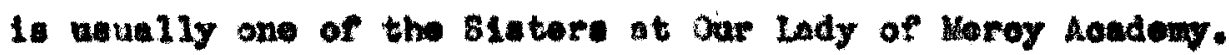

If the oamp is afrilinted with attonal or loonl canping asso1ation, this orten otimintas tho samp to meet ourtain standards, and

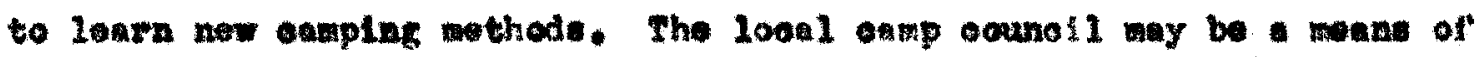
Gulding the omp townd moting comanity nods, and of obocking duplieation of work on the peipt of the samps. It mey alee oonduot camp institutes for the tralning of etare.

The organtation in the Leulovillo wee whoh tak ohlidren sont to oamp by the Loulevillo frouh AIF Fund for period are reprosented

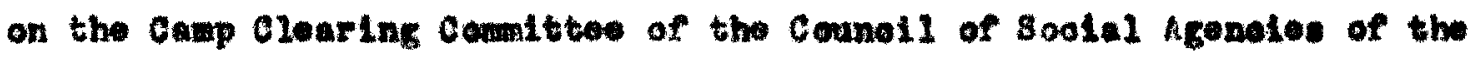
Loulorille Commalty ohost. This comitte is malnly oonoermod with the oupling poried when these onlidren are went to the oampe by the froch 
Al Pund, rather than wth the entire oamping aeson. Tharefore the oomittee does not eerve the funotion of cetting sandarde, or of condueting regular meting in whish the direotor of the Loulstille

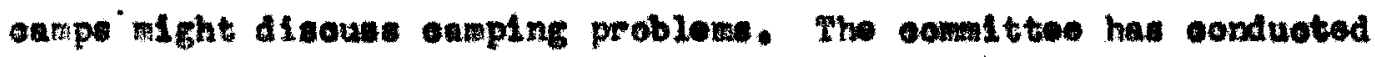
oeveral tralning Intsitutes for ocuneclore and etsfe members of the different eampe. The louleville eampe whloh have boen represented on this loanl oomittee are Coverod Dridge Resorvation, Camp 8hantituok, Camp thelan, Onlo Ploningo, herry lodges, and the Camp for Colorod Gir. 10.

Comered Bridge Roserration, Dan Beard, and Camp shnntituok aro controlled to large extent by the National organiation. The

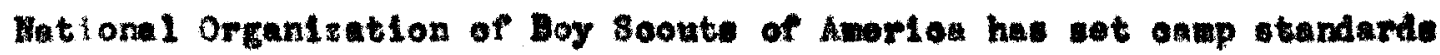
whloh the $100 \mathrm{l}$ oape wat woot, and objeotives whoh thay wat oarry out. The san is tras of the Netional a1rl Soout Organlation. Cump Cortion is influenoed by the tandirde of the Mational Organtestion of The XIng' Daughtere and son, malnly in the bypo of program whloh 1t

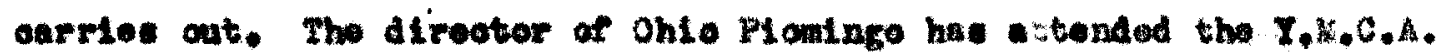
Camp DArectore' Assoolation. The reet of the onaph in the Lateville

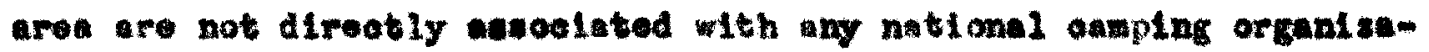
tions, and thereform have not met axy etandarde other than those whioh the 10okl administration have domanded. Publ1016y

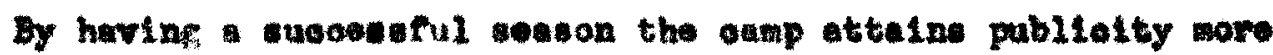
quiokly than in any other way. Publiolty is important for maldig the canp lanown to the comsundty. and is way of interproting the parpoes of the organisution to the consundty. Thare oheuld bo alose 


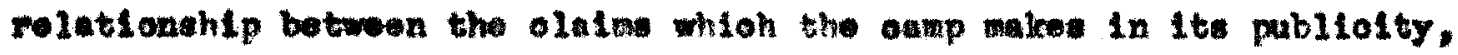

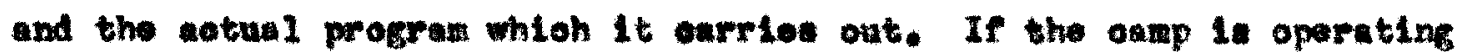
of hon-proftt belis, this ned is probubly takn for granted.

If the new papere are helped to roallse the ecmunity' neod for aamplng, this is somotimon way of getting good ooppration frow the

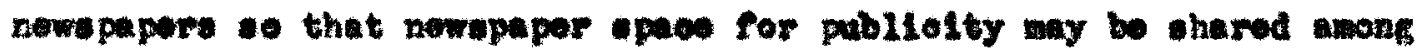
the difrorent eampe. Illustrated pamphlste or booklete aent to prospotive and forwer enmore are intorent bullders, and further wy of Intorpeting the noade, rumotion, and the werviene of the anpm to

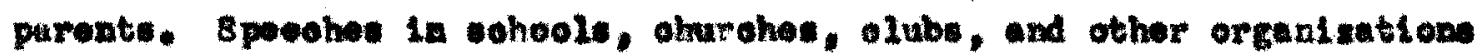

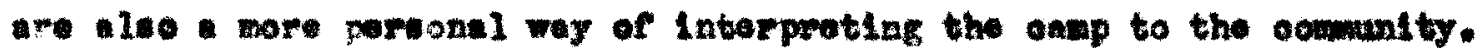
The Cang for Celored O1ris plan to have paphlet in 1939, givlng a brief hictory of the oxmp, decoription of cow of the cottro 1tles offered, and a prosentetion of the roquiremonte and noede of oamp. Thie paphiot wil be detelbuted to peronte and to indiflduals inter-

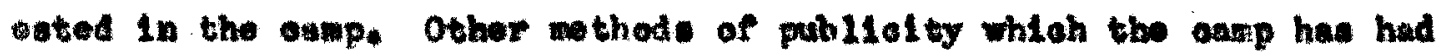
previouly are ofreular lottor", nowapaper artloles, and printod fold-

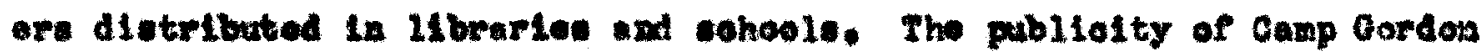
has boen ecoeapliahed winly by epoenos given by the direotor throughat tho scate at eounty oonventions of the Ins's Daughtere and sons.

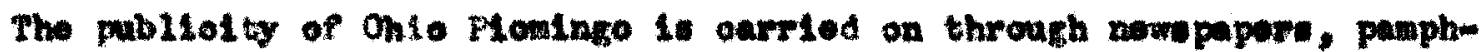
10ts, the radis, and dieplays of torial onoerning oump in the loonl

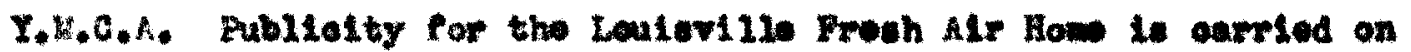
enlinly through nowspapere and pamphlete. Horry Indgos does not conduot any publiolty program other than

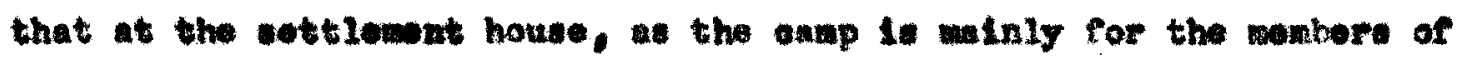




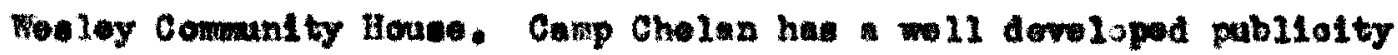
prograx. Spoeches are made by the oamp airector in wom of the sohoole and to wown's olubs in the comandty. Partion are fiven

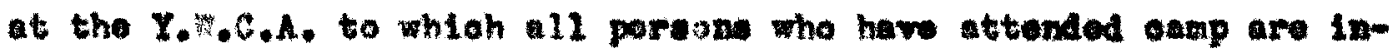
rtted. Potters are also dieplayod here, Oamp folders are fiven to the sohools at Ohrlateme and oarly in the epride. About a month before oamp opone. printed foldore deceriblng the eump and oontalning asmp poturow are ent to 11 romer abmprom.

Den Beart he som pabliolty in nowepapers, and in a folder which

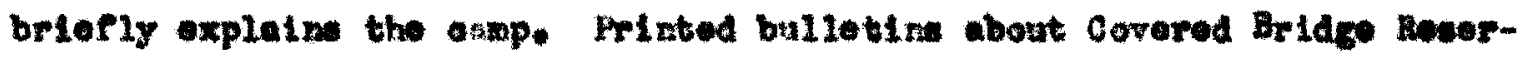
vation are went to parente of the Boy sooute before the esmp aenon apana. Sollolting is wo ane through the troop loadore during the your.

Atbractive foldere about Canp shmattuak are dietributed anong

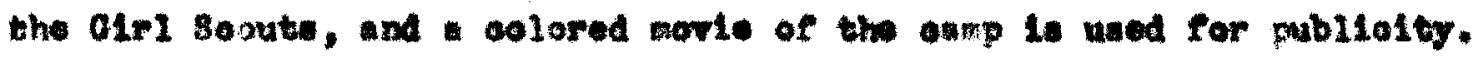

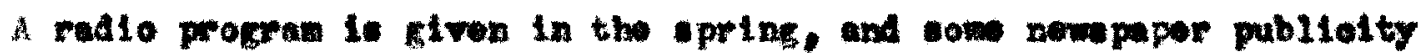
Given. Information on Jonnio ceseldy doet cottage is printed in ahuroh bulletir and com is given in nowprapore. Finaneen and Dueinose Memaenont

A camp mut firet have stable and adequate finanolal recourea: In order to plan anutruotive program. The necoelty for budget neturally Pollom, wo that definite amounte may be rolled upon for the varlous uniti of oporation. The nmout epont for parsonnel and progran whould be in fervoreble relation to that apont for equipant mantenanoe, and edalulatrative coute. ${ }^{47}$ ) If the camp is to here real coolal valus,

47. See Charecter Bueation in the gumwer Carp, fonograph III, pp. 20-21. 
the Inoowe from cumpers" foos wil hurdly be ufflelont for 1 te budget. The oump whith has an exoose ire dobt annot hope to obtain tralnod leaderatip. Dirook and Bondry boliere that oampo oporated by organisutlone

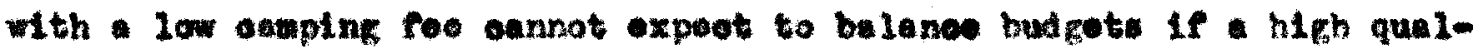

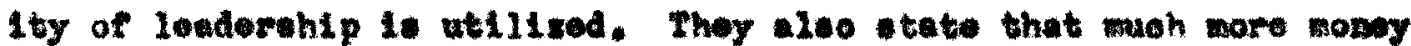
must be pats Into oanp if large chustional outoonos are to bo seaned. The Importanoe of Pisuno in rolution to the entire oumpieg prom

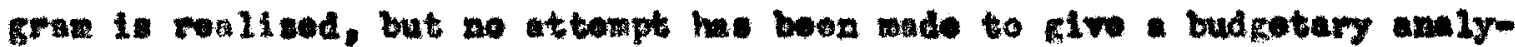

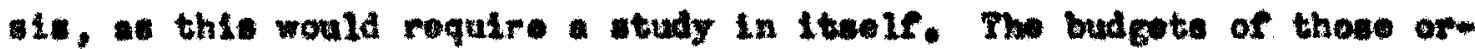

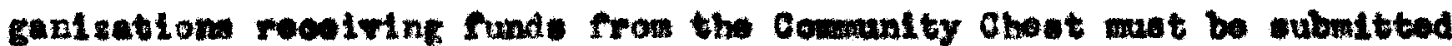
yosely to the the at for epprovel.

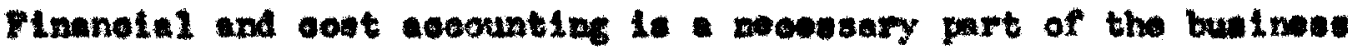

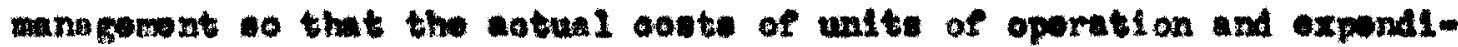
tures may be securate. Ino book ohould be audibed by repabable soovant-

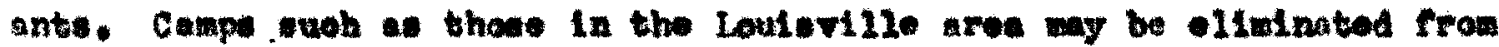
paylng taxe as the majerlty may be coneldered en elther philanthrople

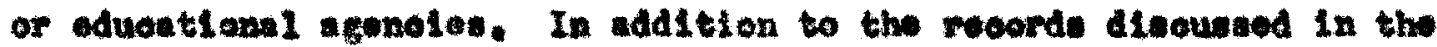
ecotione on holth, poreonme 1, and progea, an inventory of oump proporty is osential.

A11 of the oamp in the Louleville area neelve fund from pri-

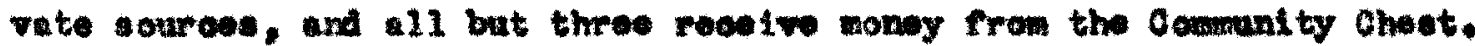

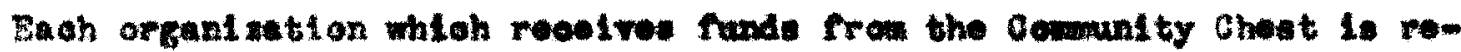
quired to have an ammal audit of 1te nocounte. The andit of the noocunta of Camp shantituok, Covered Bridge Reservition, Camp Cholan, OhLe Planinge, Herry Ledger, and Dan Beard are Inoluded in the yearly andit of the organimation of whloh thoy are art. 
Canp Chelan has bud and, and aoounte are kept of the varlou

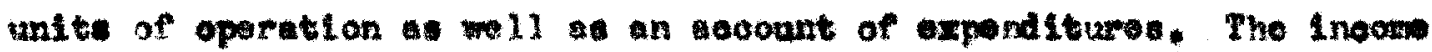
from anmere" feas is sufflelent for the budget with the exception of the Inourenoe and the dirootor's alary. The bueluas manager at osmp has oharge of the finuese for the oamp teore and the orart dem

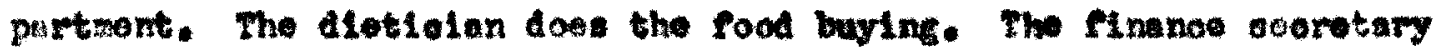

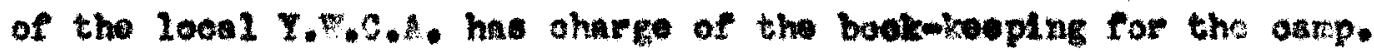
the bualrees mamage of Ohio Plomingo is ale the dietielun,

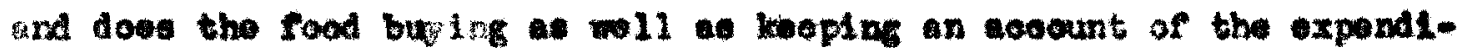
tures of the earp. The Inoone frow oumper's foas is not aumlatents for the budget.

terry Lodges has a very onell budget of one hundred and elghty

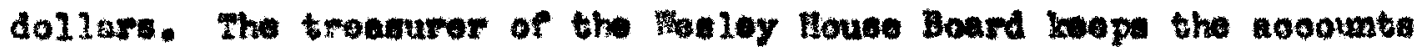
and reporte thow to the Board and to the comanl by chest yoarly. Wo

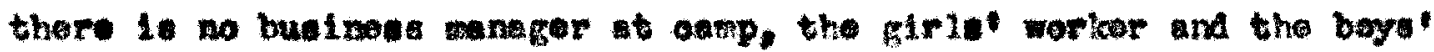

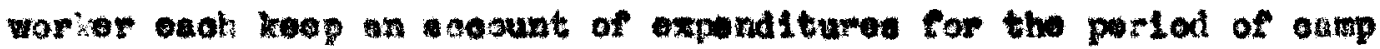
whioh they alraot.

The yourly budget for the Loulavile Fren AIr How Is approved by the Bourd. Finunelel weportin aro nent to the Omaninity Chast overy month in whioh axponditares oocur. The onp finanoos aro hasdied at

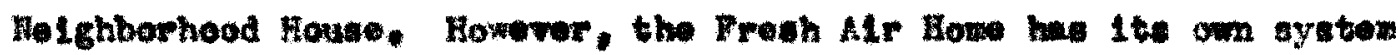

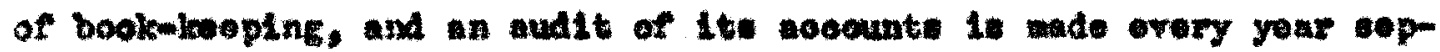
arate frow these of Holghborhod Heuse.

The alfestow of the Camp for Colowed OLIs has oharge of the

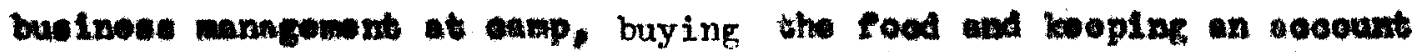

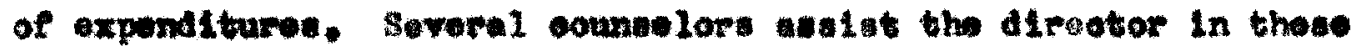


dut108. The ceretary-treasurer of the Canp Comittoe loope the nocounte during the gear. The coounte are ouditod by privete firm overy yoar.

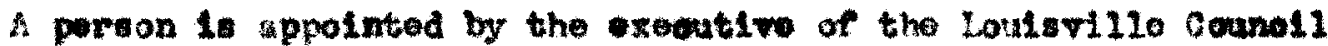

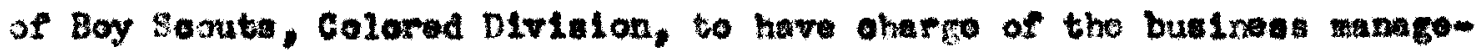
ment of Dan Beard. He is aselsted by onmp seorotary and a person in aharge of the oump oxmissary. The oenp excoutive usually does the food buylug before the oarp opens.

The Volunteere' camp does not hure a budget as the program is plasted acoordirs to the acount of woney whioh is radsed each your by subeoriptions nollatted tron the pablis. The buylng and the business

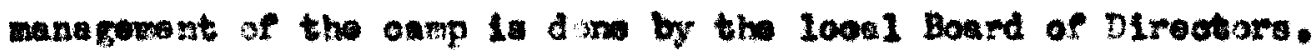

The Bound of Jemis Casidy liest Cotbage prepares the budget, whloh 1: submtted to the comanity chout yearly for approvel. The buelnees mnagemant is the reponelbillty of the troagurer and the president of the Board. The neanuts ars audited yearly by a private firth.

The diretor of Cump Corden is raponible for the bueinose sanagowent of the camp. The budget is subjot to the approvml of the

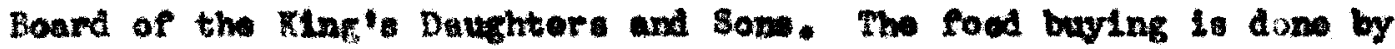
the troasurer of the Board, with the advied of the direator. The com sount of the asmp are eudlted overy two yours.

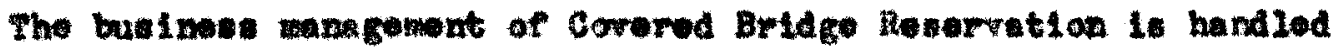
by the Ioon 1 Cound 1 of Boy Seouta, white Diriston. The person in

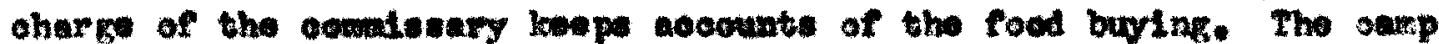
olerk it in ohnre of the oump trading powt tho anp bank, and the 


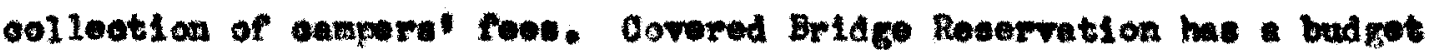
for malutenunse but not for oporation. The oawp has dabt inourred through repairs and wintemanoe costo. The actual oosts of the varloue untte of oportition, and socounts of expenditures are lcopt. The ineone

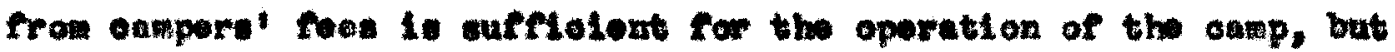
not for malntomano.

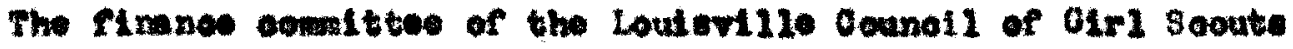

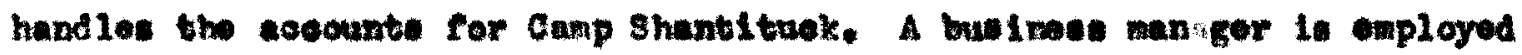
at the eanp. A budget is prepared of the various units of operetion.

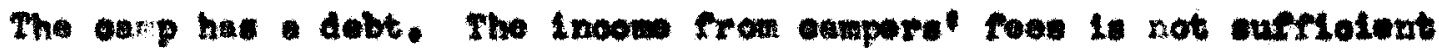
Por tev budget.

Purchasing

Untortunutely, in those oxpe whioh do not have o eamp nanager, the oup direotor wat take the reaponstbility for the purohasire of

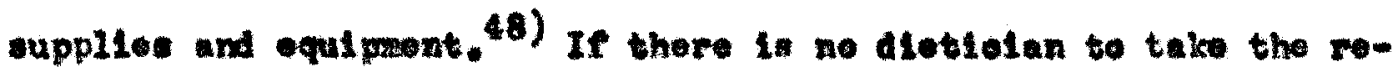

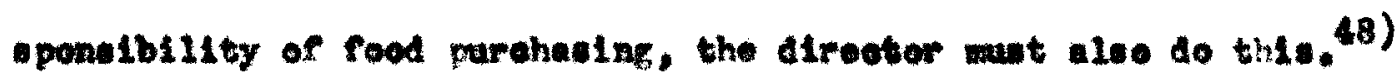

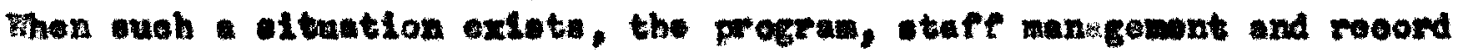
keeplag are ofton neglooted. As mah of the foed buying as is posulblo should be don bafore capp opene. If apeoffloatlone for food are ant

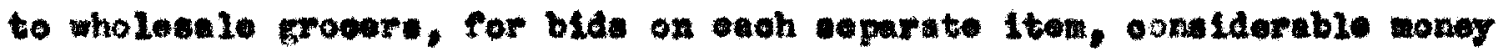
way bo enved. Inventory reoorde of th total quantity of each kind or food used during the seceon are nocossury.

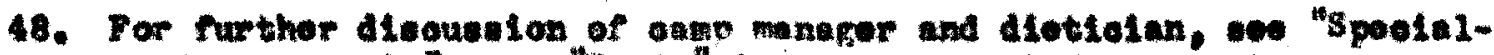

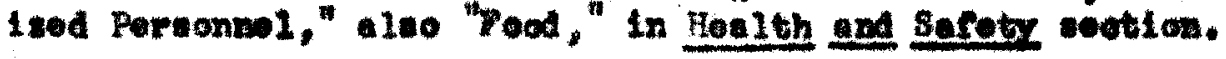


Insuranos

The uinde of inaranoe esential for oampe listed by the olevo-

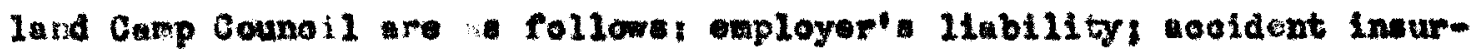
anoe ( $t a$ oampers and emnloyees in eamp and on hikes, in transit to and from the onmp), fire ineuranoe (building, equipont, appliea, prenel proporty); limb1116y, fire and the ft (automoblie).

Camp ShantLtuek, Jennle Casaldy heat Cottage, Dan Beard, Corerod Hridge Revorration, Canp Obelan, The Loulowilie Frosh Alr How, and tho Volunteors" Canp all have thre and tormado Insuranoe. In addsti n to thic. Covered Eridge Regervation ard the Volunteers' Camp have gooldent ineuranos.

Jemie Casaldy Rost Cottage ha aditional inauranoe agalrat theft. The incurenoe for camp ardon 1s oovered in the rental for

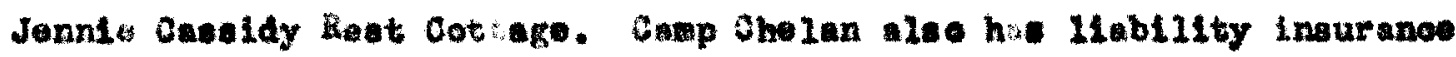
for the aport. Onle Plomingo ha liability innuranos which dow not

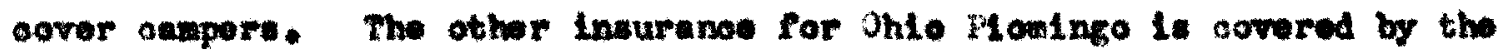
Nationel Park 8errioe, ae it oms the oxmp alte. Werry ledges has no Insuranoe yot. The omp for colorod Girle bis no incuranoe in addition to that of Lnooln Inetitute, whis the is rented by the samp.

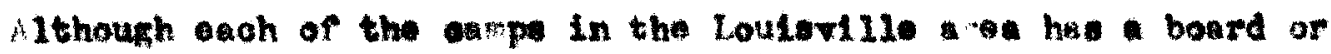

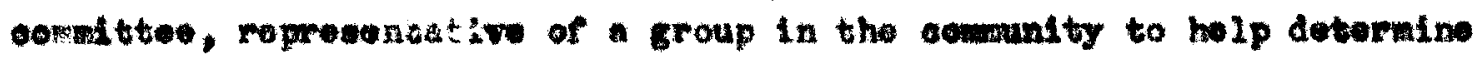
operatiag pollotes, their reletion to the oup atafe is not olear in 
many of the ande. Camp Chelan is the only ane whose director has realised the importance of place for etaft nombera and parente of anpere on the camp cownlttee.

The rolationshtp of varlous oump orgend setlons to each other Is not wery olearly underatod by them. The neting of the Camp Clear-

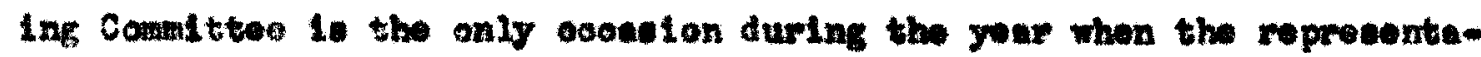

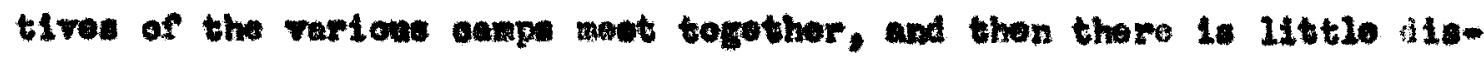
ousalon of thatr mutual relationuhip.

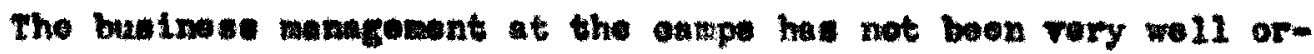

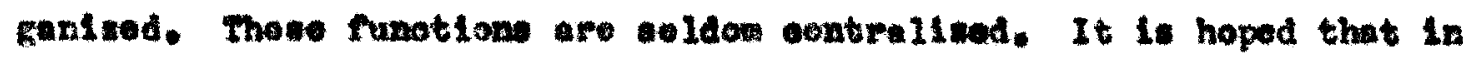

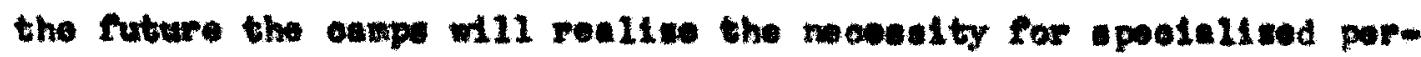
oonne 1. In orter to bul1d up otandarde of cosial adalnietration an prosented throughout this otrudy. 
conerus Ion 


\section{COHCLDSION}

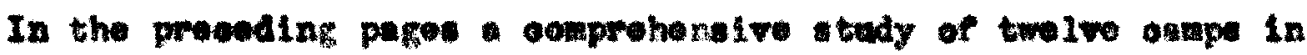
the Loudeville ares ho been submitted. This oceparatire obudy hat

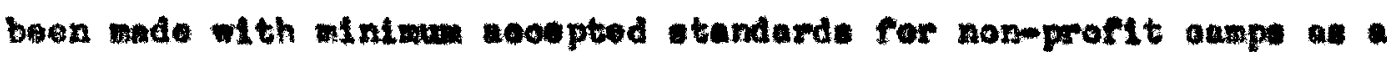
basis. A dolre to deplot the prosent tatas of Loularille as a com-

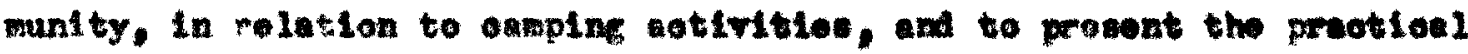

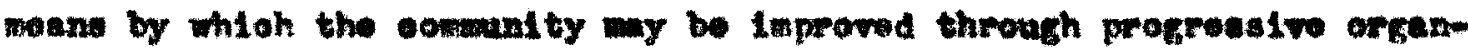

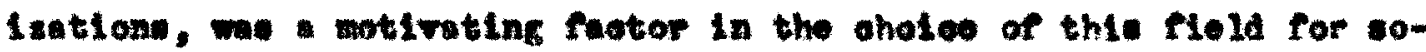
olal lavertigtion.

This obudy rovesis that more adequate equipasnt, better trained permonnel, and the dovlopment of elesper lines of adninietrative author1ty aro noeded in wont of the eamps. A wore culteble looation is hepod for by woveral of the organt sution. In all of the eampe the prograx

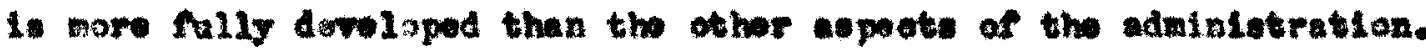
An outstending nod is tho formiation of anp stardends by the

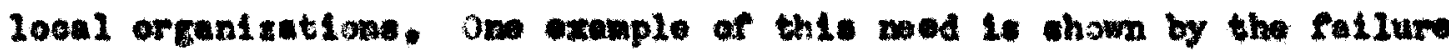

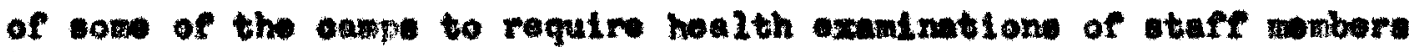

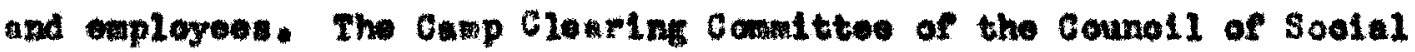

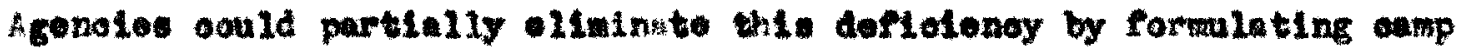

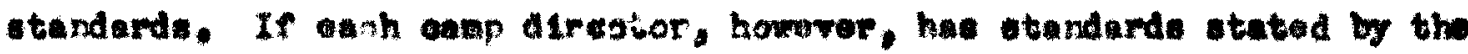

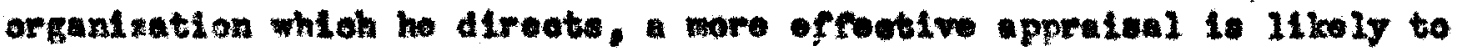
be the result. Camp Shantltuok, Covered Bridge Revervation, and Dan

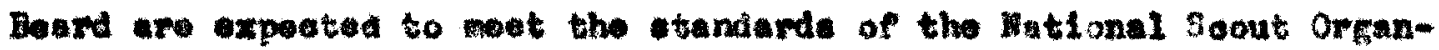
1Eatione wh whioh thy are efel11atod. 
Hany of the Louleville oampe have fallod to moot acoopted standards largely boosuse of a leok of adequate and trained porsonnel. A sincere attempt is mide by most of the directors to rearuit the beat personnel arailable. Unt1l the importance of specialized training for the task is reallsed by the oommitty a whol, the opplloants for such position will not have the doalre to obtein this training, nor w11 funds be alloogted to these organlzatione whloh w11 onable then to obtain wall trainod stafe.

Moet of the oamp in the Lowloville area are handioapped by inadequate funds, sowe to a much greater degroe than others. As a rosult most of the stafe in 211 of the oampe wast voluntoor their servioes for the season. Thervfore, those who aro adequately trained are forced to look eloewhere far poeitlons. This altuation would be solved partialIy if eamp direotors employed young pereone as funior counselors, and offered them tralning in oamp. Camp chelan 1a the only organization which has eystem of stafe training well deroloped at camp.

suoh in-servio tralnine is only one mothod, and must be aooomplishod by cemmentty awarems of the influenoe whioh personnel has on the administration of the eamp. The value of coolal and group work traluing in relation to objeotives has yot to be realized by some of the 100al oamp authoritios.

A furthor contribution to this problem would be a ontinuation of such program as that oonducted by the Reoreation counoil of the Loularille Commanity Chest in 1929. A progran was organized for the purpose of arranglac a serles of conferenoes for board mombers and oanp direotors. These conferonoes were not held but a training 
comittes planned and oonduated a oamp institute for oounselore. Suoh plan is benefioial not only for the training of oamp stafe, but also for bringing about an understanding on the purt of the oamp direotore as to their relations to ooh other in meoting cimping needs in the oomunity. Disous lons as to the various needs which the oumps are noeting in the ocmmity would be very advantegeoua.

The laok of adequate personnel has had an influence upon administration in the Louiaville carp. a funetiow of ataff nembera are not olearly defined in oom of the organizations. The boards and comwittoes often do not funotion at they are theoretically organised to do. The businese management is often divided anong ataff members as an extra burden, rather than entralled as the responsibility of one or two persone. In sote of the empe the extre duties for which ne staff are proplded are "dumped" upon the direotor with the result that the ctafe onnnot be properly upervised or adequate records kept of campers. Boards and comitteos could lso be nare influential in gainIng further publioity for wost of the oamp, wo that the commity might beoom more conclous of camping noeds.

In the samps in the Loviorille area moh omphasis has beon placod upon actirities, with woll developed etivity progran as the result In the marity of onses. If the omp is to have a real soolal ralue, the development of each inditidual acoording to his noeds is the main point to bo troused.

Few of the Louierille organlsation hare oontimed to keep in toush with the boys and girle after the oamp aeason, so the muoh of 


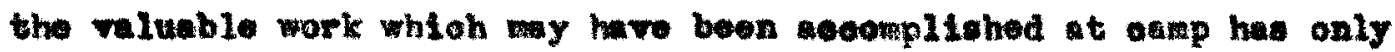
- Hall influenes upon the indiridual's whole experienes. This conteot onnot be contianed by thoee oampe which are not eponeored by organlatione whloh oarry on work during the entire yoar. Daly a fon

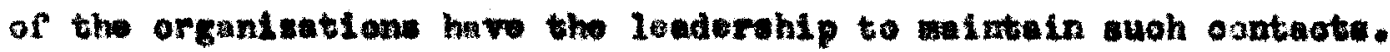

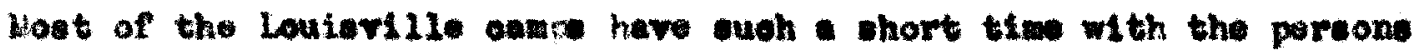

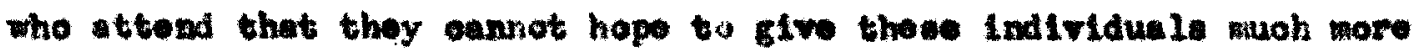

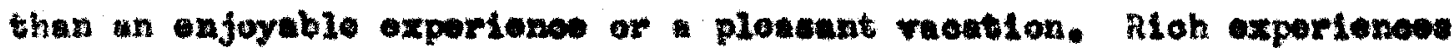
oan be afforod to the indiridual in this short pertod whioh will orom

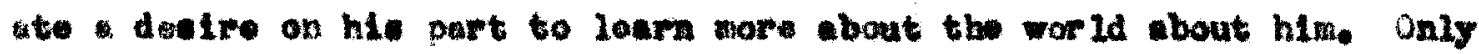
a fow of the anpe in the Laulurille ares have fully roalled the op-

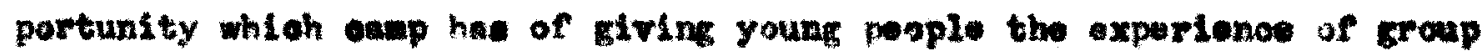

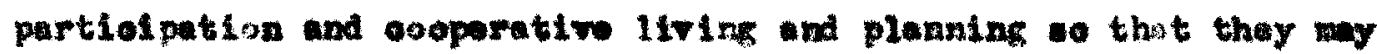

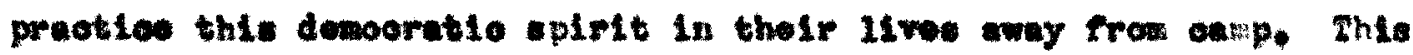

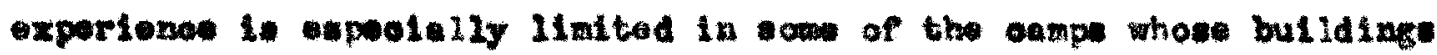
wore not origimily planned for a onnp.

Although abjeotiwe are rery often otitad by percon who have a

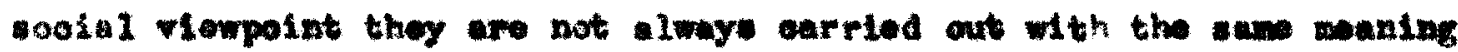
end wal. Thore Is roul danger of this in most of the Loulaville onmpe, as fow of the orgenisation rentew the alme yenty with stafe

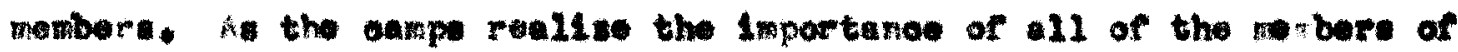
the aanp having port in the formalation of objective, this danger \$11 be leasened.

the divelopment of erfeotive omping orgentiation it derondent

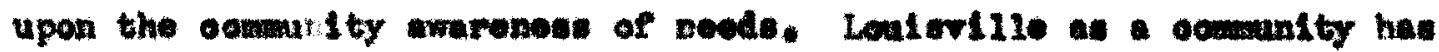

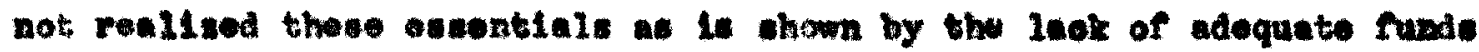


in the wajority of the eamps. The Laisville Fresh Air Hore, the only froe racation how for underprifileged familles in Loulsville, is sup ported by the Community Chest, but the funde are not suffiatent to maintuin tho best type of program or to attraot trained personnol. Louisv110 has not yet reallsed the nooseity for oup supported by publlo funds. However, this ned is rery rital, as ohom by the fact that of the 1,977 wo epplled to go to the Loulerille Preah AlF Hom in 1938, only 931 oould be acoomadated. The Kational Furk Serrice has rilled this gap somwhat by eatabliehing the otter Grook projeot mar loulsrilie. It remains to be eeen if the ecmaunity will later undertake to meet its needa with aniospal anp.

Jeanie Cassidy Roet Cottago might also 1111 a greater oomminity need by being ueed as tres reation home for poreone in naed of a healthrul rest in the ocuntry whe would be referred to the oottage by soolal agenoles in Loulspillo. In this oase at least trained reoreational leader would be needed to plan progren. If Hount Meroy 1s able to contime omploylng reoreational worker and the imming pool is repaired for use, It may edequately serve as reoation home for working gir is in Louist110.

The rooent unrvey oonduoted by the comanity chest is a step forward in the evaluation of those eampe in the Loulaville area whioh are administerad under the chest. All of the Loularille oarpe are in need of a continuing prosess of self-evaluation in the light of devoloping standards with opeolal reforenoe to oomanity neode. 
BIBLIDORAFIT 


\section{BIaLIOodevth}

\section{Beoly}

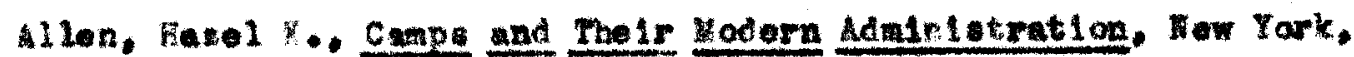
The romans froes. 1330 .

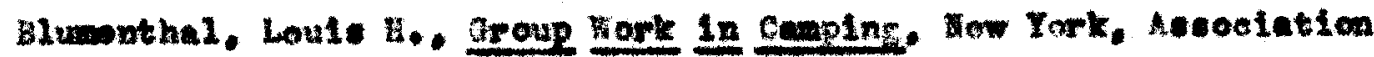
Prese. 1987.

Dinook, H. S., and Rendry, C. H., Cemping ane gherecter. War York, Aceoolation Proes, 1901 .

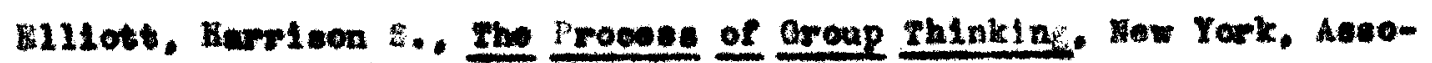
clation Proen. 1982.

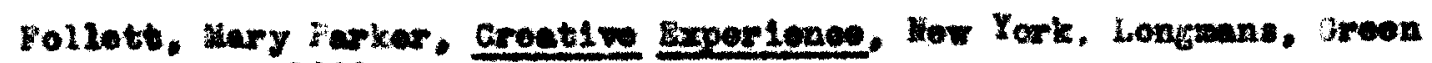
and Company. 2820.

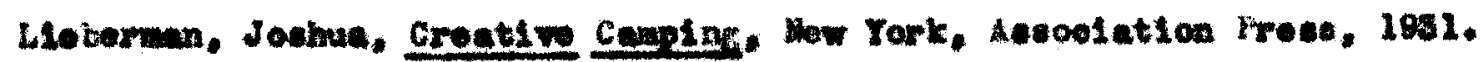

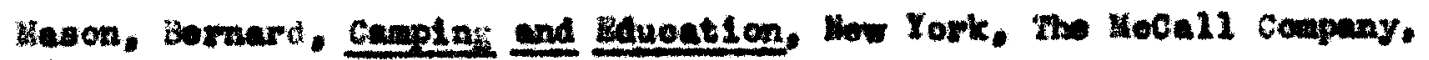
200.

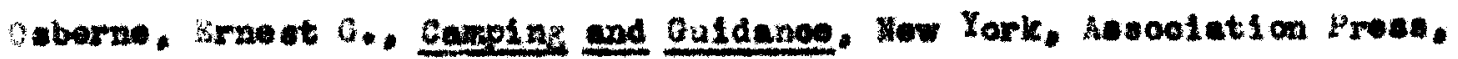
1987.

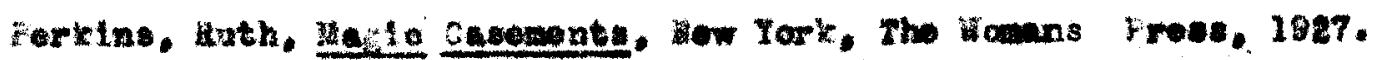

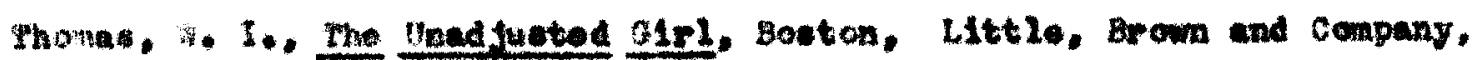
1923.

Booklete and Penphlete

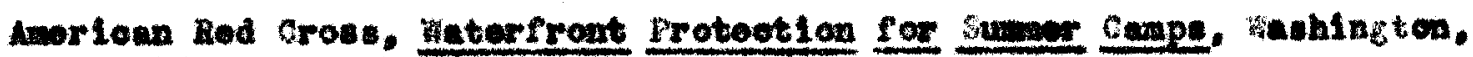
D. C., 29se.

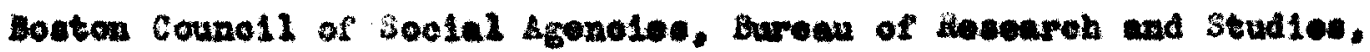
Btenderde for Eviluation of Buer Cenpe. Deeombor. 1987.

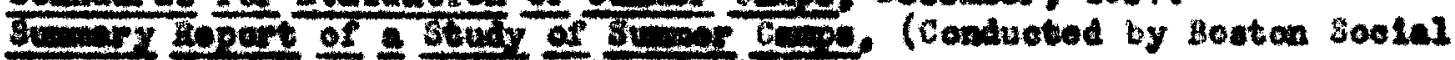
Agenelos and other Orgentations. 166. 
Boake and Peophlote (oont1 mued)

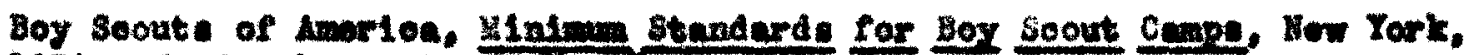
2900. Eandbook far Boye. Waw repk. I016.

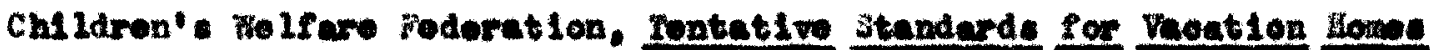
and Canpe, how Tork, 1982.

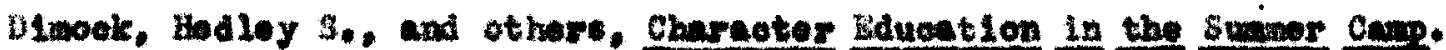

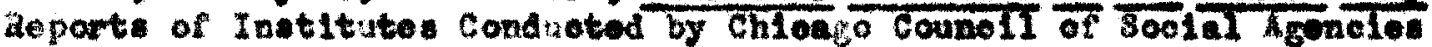
and reorgo MLllian College.

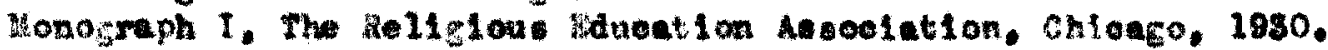

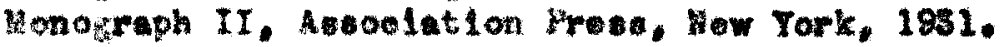

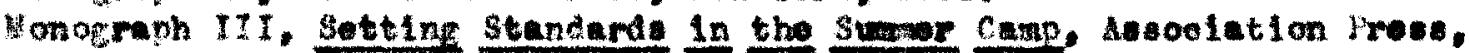
Hav York. 1036.

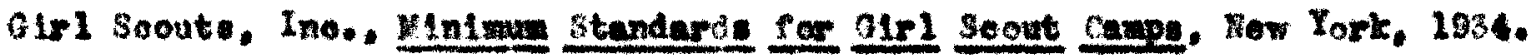

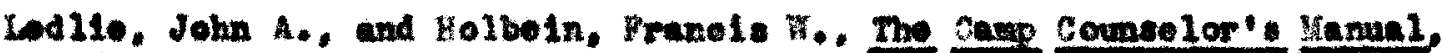

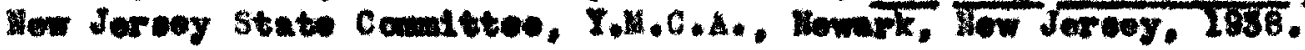

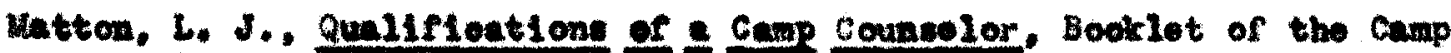

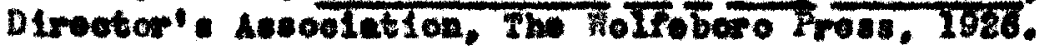

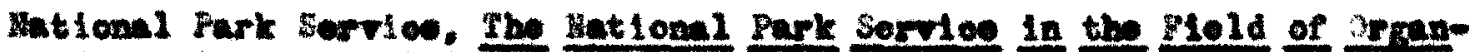

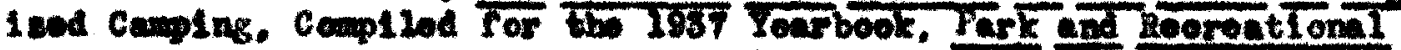
Prognowe.

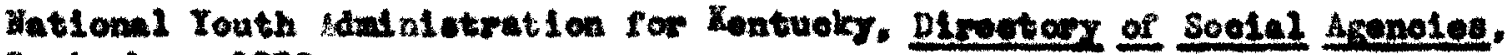
september, $108 \mathrm{~B}$.

Salowon, Julien Lamis, oromiced Ceape in Stete jarks (with Appendix

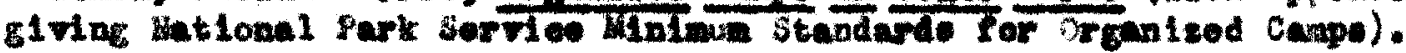
Dnited States Departant of the Interlor, Hational Fark Servioe. 1936.

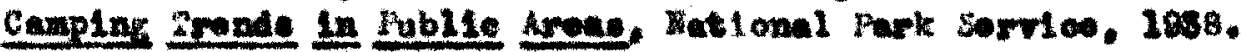

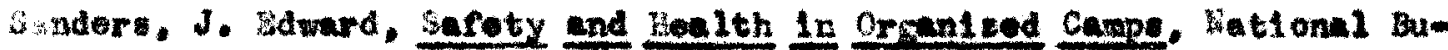

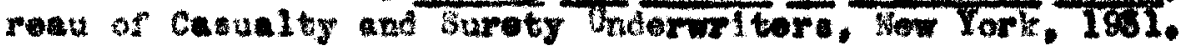

The gounoll of Soolal Agenoles of the Louleville comanity Ohest. Dlrootory of sumar caxpos. 1937.

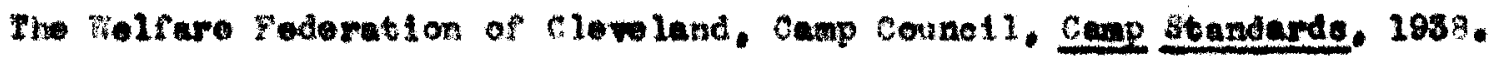

\section{Serasines and Artielee}

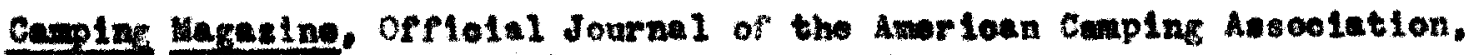
Ann Arbor, Niokigan, Monthly. 
Heresine and Antloles (oontirned)

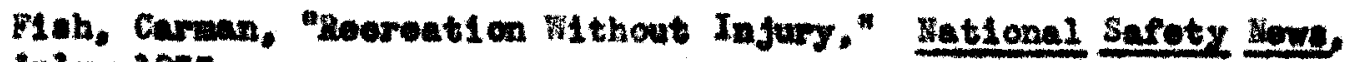
July, 1987.

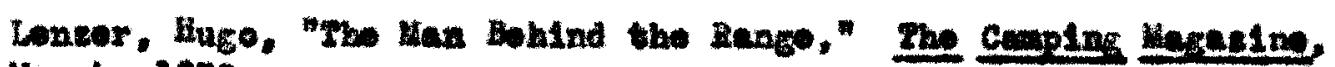
Maroh, 1988.

Sunder", Ldmard J." "Sef' Caup for Youne Anorlon," Mattonel Safoty Dewe. Juns, 1250. 